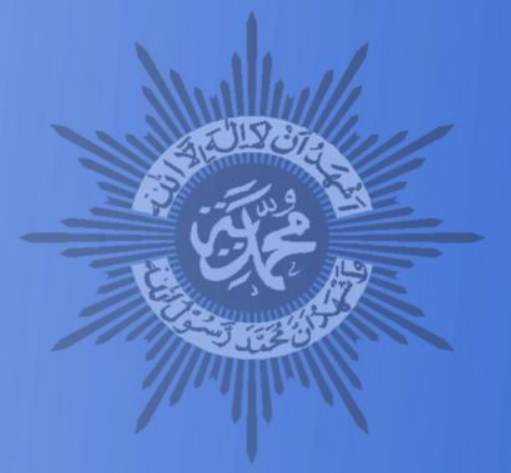

Sungguh, Jslam adalah agama yang kamprehenship (al-Shumuliah), agama yang menjelaskan segala aspek kehidupan secara utuh. Oleh seleale itu, memahami hakikat ileadah, syariah dan akhlaq harus bersumber pada paradigma Islam. Paradigma Islam tidak mengembangkannya ke arah belas nilai (free value), akan tetapi disesuaikan atau diselaraskan dengan nilai dan tuntunan ajaran Jslam.

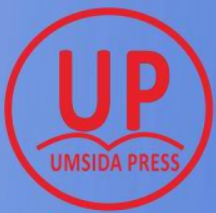

UMSIDA PRESS

Jl. Mojopahit 666 B Sidoarjo
BUKU ANAR

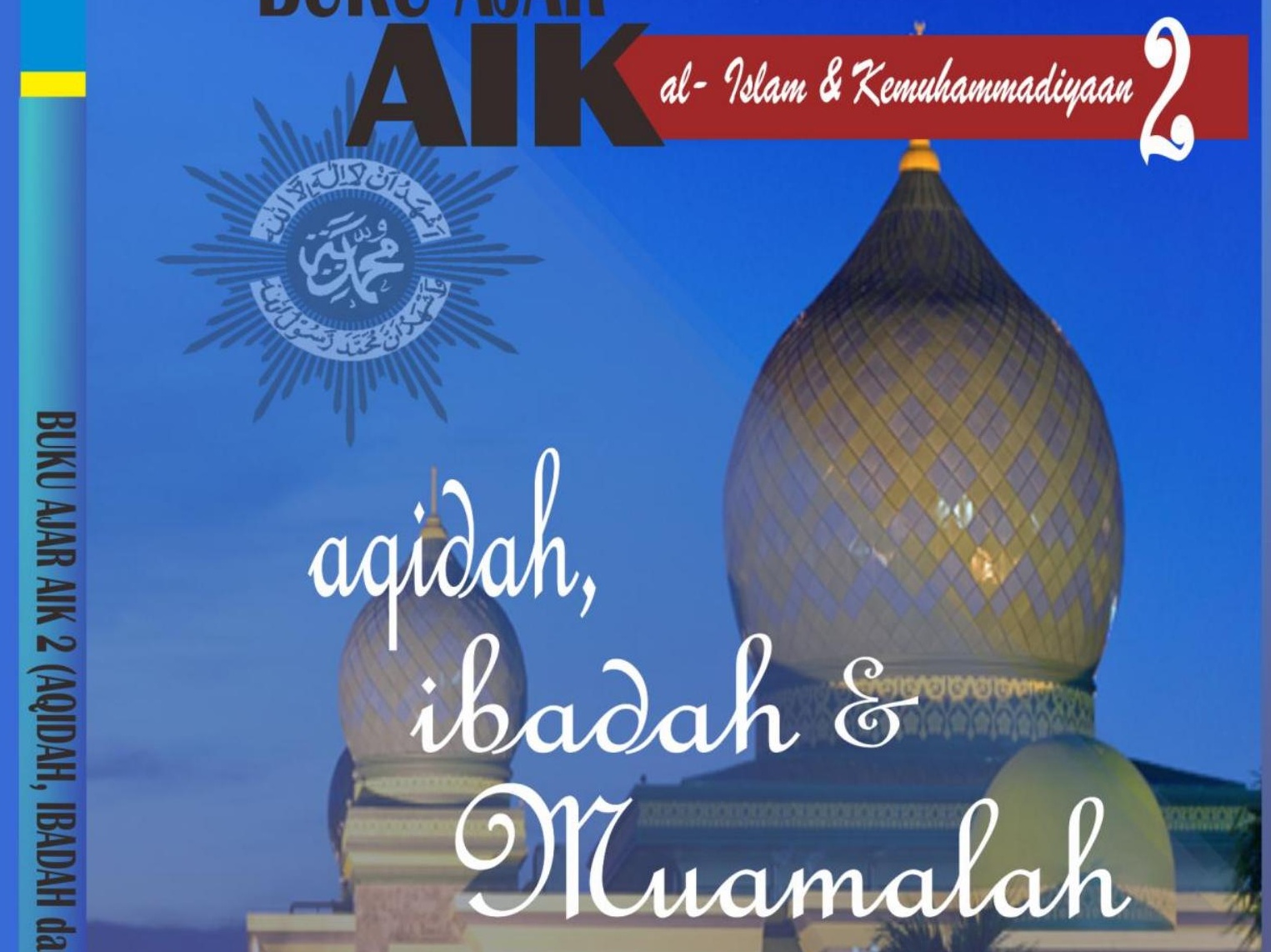

Penulis:

Supringath, Misds

Anis Farihak, M.STh.

$x+\frac{1}{20}$

$\min 28$

WNIERSTIAS MUHAMMADIYAH SIDOARNO

2017 


\section{BUKU AJAR \\ AL-ISLAM DAN KEMUHAMMADIYAHAN - 2 \\ (AIK - 2)}

Penulis

Supriyadi, M.Pd.I

Anis Farihah, M.Th.I

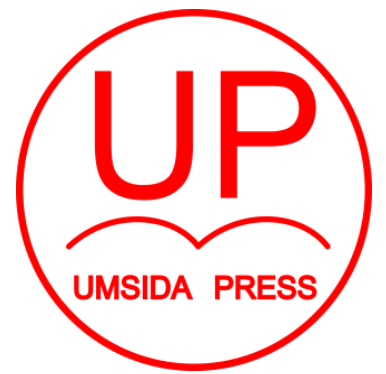

Diterbitkan oleh
UMSIDA PRESS
J1. Mojopahit 666 B Sidoarjo

ISBN: 978-979-3401-76-8

Copyright@2017.

Authors

All rights reserved 


\section{BUKU AJAR}

\section{AL-ISLAM DAN KEMUHAMMADIYAHAN - 2}

(AIK - 2)

\section{Penulis :}

Supriyadi, M.Pd.I

Anis Farihah, M.Th.I

\section{ISBN :}

978-979-3401-76-8

\section{Editor :}

Puspita Handayani, S.Ag., M.Pdi

M. Tanzil Multazam, S.H., M.Kn.

\section{Copy Editor :}

Fika Megawati, S.Pd., M.Pd.

Design Sampul dan Tata Letak :

Mochamad Nashrullah, S.Pd

\section{Penerbit :}

UMSIDA Press

\section{Redaksi :}

Universitas Muhammadiyah Sidoarjo

J1. Mojopahit No 666B

Sidoarjo, Jawa Timur

Cetakan pertama, Agustus 2017

(C) Hak cipta dilindungi undang-undang

Dilarang memperbanyak karya tulis ini dengan suatu apapun tanpa ijin tertulis dari penerbit. 


\section{KATA PENGANTAR}

Buku AIK 2 ini memotret hakikat ibadah maghdah (ibadah shalat, puasa, haji, dan ibadah maliyah), akhlaq serta muamalah dengan mengupas secara rinci makna spiritual di balik setiap ibadah maghdah, akhlaq dan muamalah. Dengan demikian, diharapkan Islam secara teori ideal, sekaligus mampu diaplikasikan. Islam yang diwujudkan adalah Islam yang pernah ditampilkan Nabi Muhammad SAW, dan agama orang beriman (agama kaffah), yaitu kebenaran yang dikatakan sebagai teori, sekaligus mampu dipraktikkan sebagaimana teorinya, sehingga berimplikasi dan dirasakan oleh umat Islam serta masyarakat luas (rahmatan lil 'alamin).

Besar harapan untuk mahasiswa, mudah-mudahan kehadiran buku ajar AIK 2 ini dapat memberikan spirit dalam beribadah, berakhlaq, dan bermuamalah serta mengungkap makna spiritual ibadah dalam kehidupan sehari-hari sesuai nilainilai Islam. Sehingga dapat mengamalkan ajaran Islam sesuai AlQur'an dan Al-Hadits. Sebuah mimpi yang tentu tidak hanya menjadi utopia saja, dan itu harus kita wujudkan sekarang juga, dan paling tidak buku inilah yang akan menjadi awal dari semuanya.

Sidoarjo, 24 Agustus 2017

Penulis 


\section{DAFTAR ISI}

Kata Pengantar................................................................................ i

Daftar Isi ......................................................................... ii

\section{BAB I HAKIKAT IBADAH}

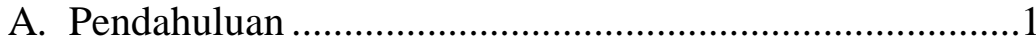

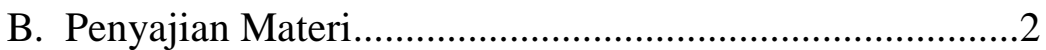

1. Konsep Ibadah ..............................................................

2. Ibadah Mahdhah dan Ghairu Mahdhah ........................8

3. Fungsi dan Hikmah Ibadah ..........................................

4. Makna Spiritiual Ibadah Bagi Kehidupan Sosial ......27

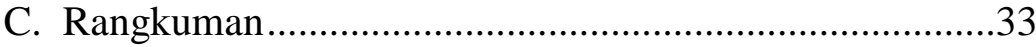

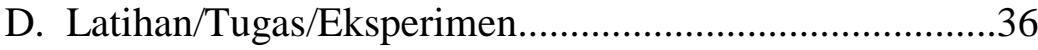

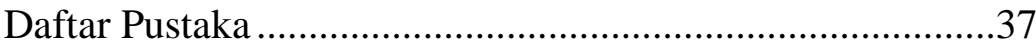

\section{BAB II SHALAT DAN MAKNA SPIRITUAL SHALAT}

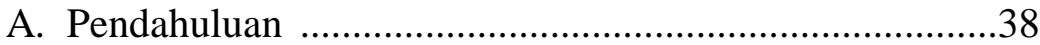

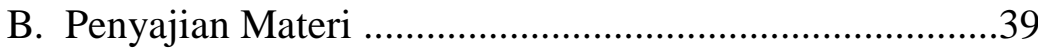

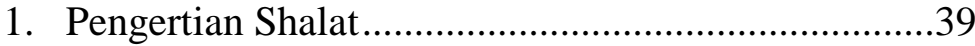

2. Kewajiban Shalat........................................................

3. Tujuan dan Fungsi Shalat ...........................................46

4. Akhlak dalam Shalat ...............................................50

5. Ancaman bagi yang Meninggalkan Shalat ................58

6. Makna Spiritual Shalat ..............................................61

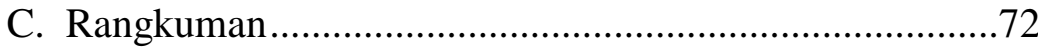

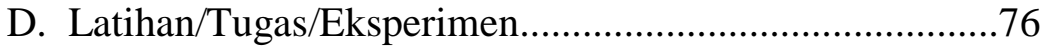

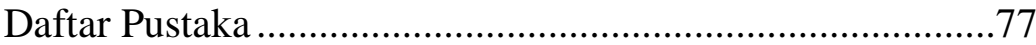

BAB III PUASA DAN KORELASINYA DALAM PEMBENTUKAN INSAN BERKARAKTER 


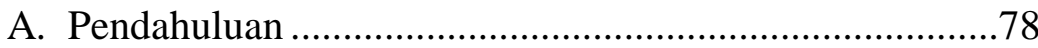

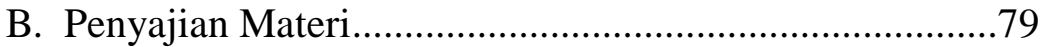

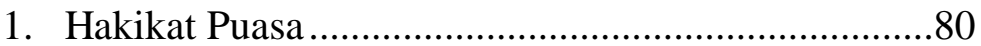

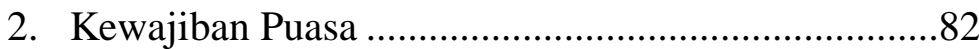

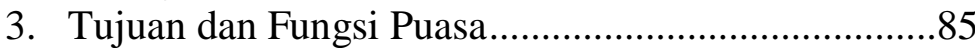

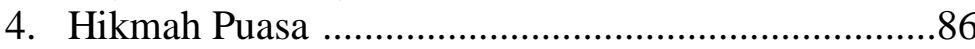

5. Pengaruh Puasa dalam pembentukan Insan

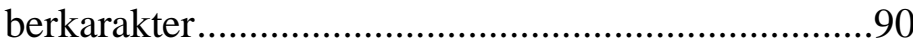

6. Makna Spiritual Puasa.................................................93

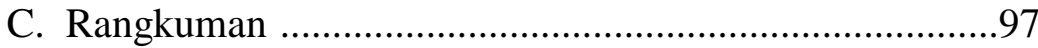

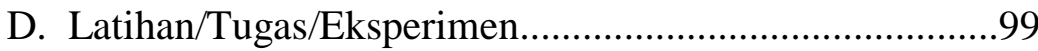

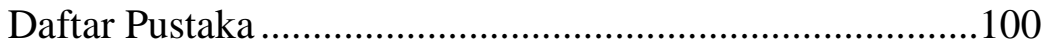

\section{BAB IV HAJI DAN MAKNA SPIRITUALNYA DALAM KEHIDUPAN}

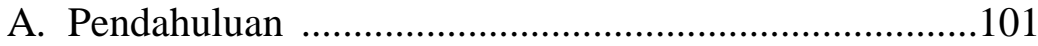

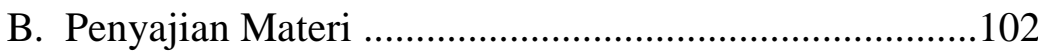

1. Hakikat Haji ................................................................ 102

2. Sejarah Haji .............................................................106

3. Kriteria Haji Mabrur ...............................................118

4. Hikmah Haji ............................................................123

5. Makna spiritual haji bagi kehidupan sosial.............125

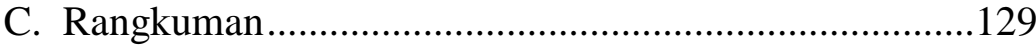

D. Latihan/Tugas/Eksperimen.........................................133

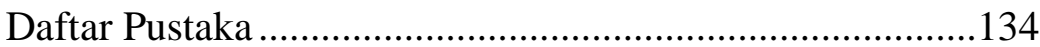

BAB V IBADAH MALIAH DAN MAKNA SPIRITUALNYA DALAM KEHIDUPAN SEHARIHARI 


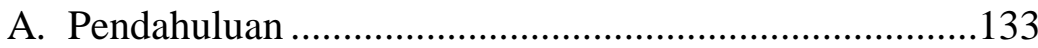

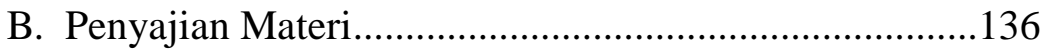

1. Hakikat Ibadah Maliah ..........................................136

2. Macam-macam ibadah maliah (zakat, infaq \&

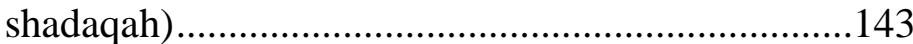

3. Urgensi ibadah maliah ..........................................152

4. Hikmah menjalankan ibadah maliah .......................154

5. Makna spiritual ibadah maliah dalam kehidupan

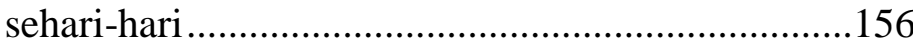

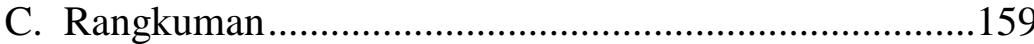

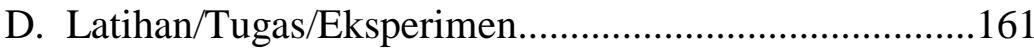

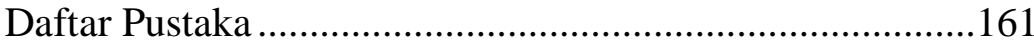

\section{BAB VI AKHLAQ DAN PERANNYA SEBAGAI MODAL SOSIAL BAGI KEBERHASILAN HIDUP SESEORANG}

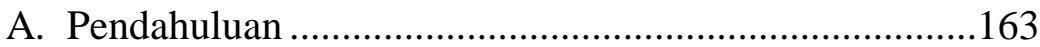

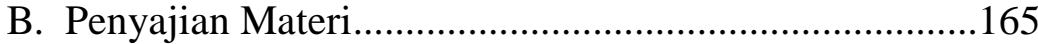

1. Pengertian akhlaq, etika dan moral ..........................165

2. Sumber akhlaq dalam Islam ....................................174

3. Peran akhlaq dalam keberhasilan hidup ..................177

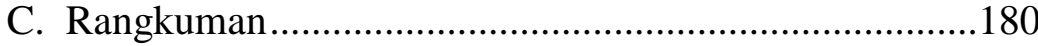

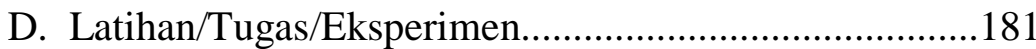

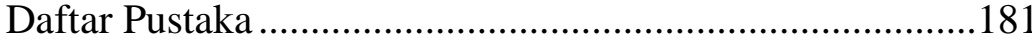

\section{BAB VII MACAM-MACAM AKHLAQ DAN PERAN AKHLAK DALAM KEHIDUPAN BERBANGSA DAN BERNEGARA}

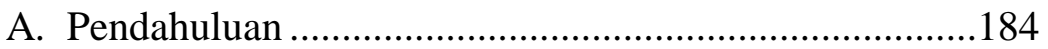




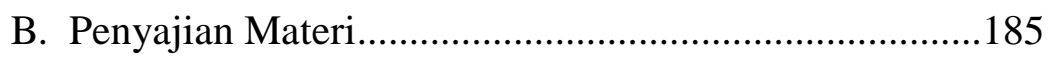

1. Akhlaq terhadap Allah dan Rasulullah....................185

2. Akhlaq individual dan sosial ..................................188

3. Akhlaq terhadap lingkungan ...................................192

4. Peran akhlaq dalam kehidupan berbangsa dan bernegara ................................................................194

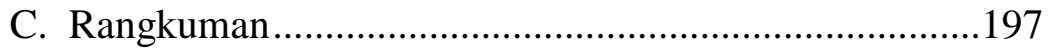

D. Latihan/Tugas/Eksperimen..........................................198

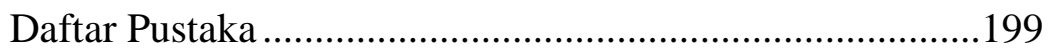

\section{BAB VIII AKHLAQ DALAM KELUARGA DAN LARANGAN KEKERASAN DALAM RUMAH TANGGA}

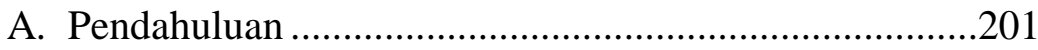

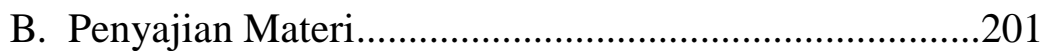

1. Urgensi keluarga dalam hidup manusia .................201

2. Akhlaq suami istri .................................................204

3. Akhlaq orangtua terhadap anak ...............................208

4. Akhlaq anak terhadap orangtua ...............................212

5. Peran akhlaq dalam membangun keluarga sakinah. 214

6. Larangan kekerasan dalam rumah tangga ...............217

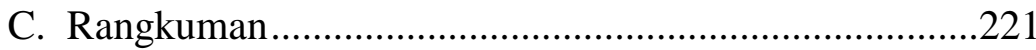

D. Latihan/Tugas/Eksperimen.........................................224

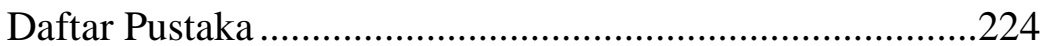

BAB IX AKHLAQ SOSIAL DAN PANDANGAN ISLAM TERHADAP BEBERAPA PERSOALAN: KEMISKINAN, KEBODOHAN DAN PENGANGGURAN

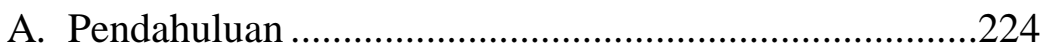




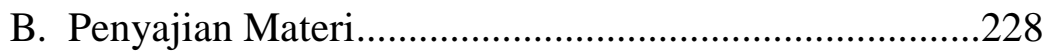

1. Pandangan Islam tentang kehidupan sosial.............228

2. Masyarakat dambaan Islam...................................231

3. Toleransi inter dan antar umat beragama dalam Islam .233

4. Prinsip-prinsip Islam dalam mewujudkan kesejahteraan sosia ...............................................240

5. Pandangan Islam terhadap beberapa persoalan: kemiskinan, kebodohan, dan pengangguran ..........243

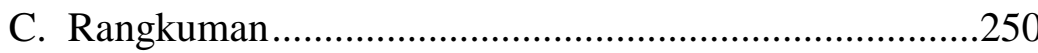

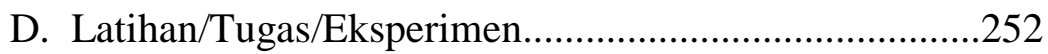

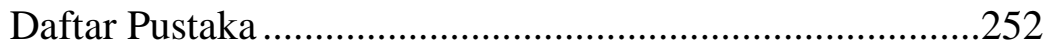

\section{BAB X MUAMALAH DAN PANDANGAN ISLAM TENTANG KEHIDUPAN DUNIA}

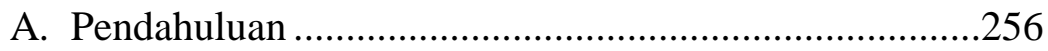

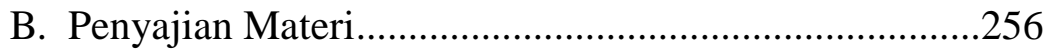

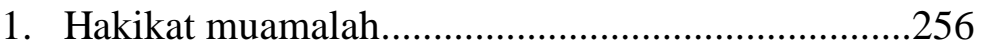

2. Pandangan Islam tentang kehidupan dunia .............259

3. Makna spritual muamalah tentang kejayaan hidup .262

4. Ruang lingkup muamalah.......................................265

5. Prinsip-prinsip bermuamalah ..................................269

6. Akhlaq bermuamalah ............................................22

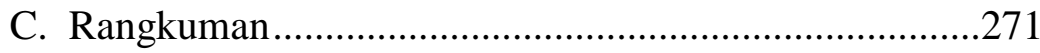

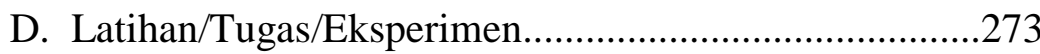

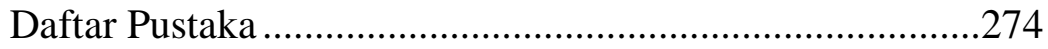




\section{BAB XI ISLAM DAN PERSOALAN HIDUP}

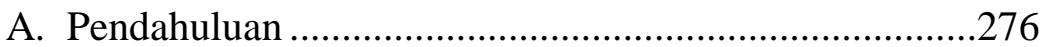

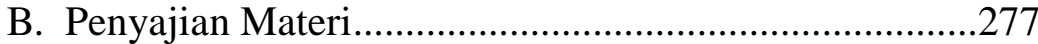

1. Hakikat hidup dan kerja .........................................277

2. Rahmat Allah terhadap orang yang rajin bekerja....280

3. Akhlaq dalam bekerja............................................285

4. Profesionalisme dalam bekerja................................286

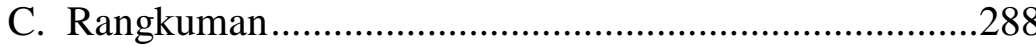

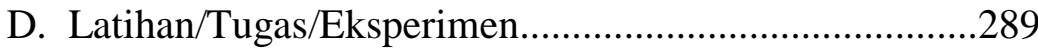

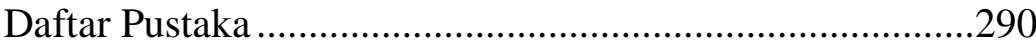

\section{BAB XII HARTA DAN JABATAN DALAM PANDANGAN ISLAM}

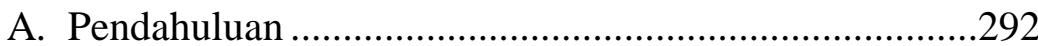

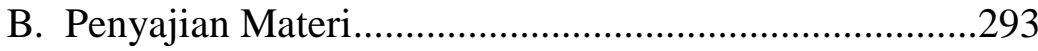

1. Harta dan jabatan sebagai amanah dan karunia Allah .293

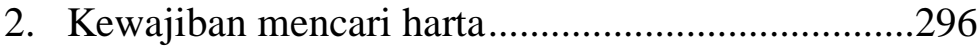

3. Sikap terhadap harta dan jabatan..............................300

4. Pendayagunaan harta dan jabatan di jalan Allah.....301

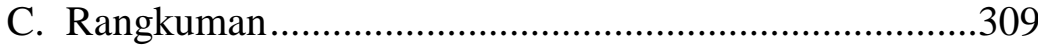

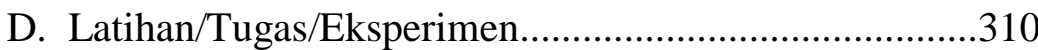

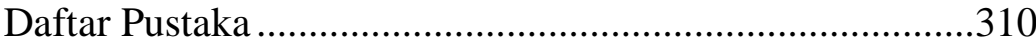

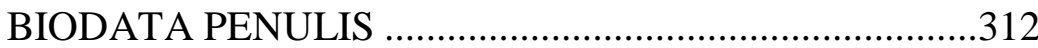




\section{BAB I \\ HAKIKAT IBADAH}

\section{A. Pendahuluan}

Mengapa manusia harus beribadah? apakah tujuan hidup manusia di bumi? Kenapa manusia lahir dan dihidupkan? Apa makna hidup ini?. Beberapa pertanyaan tersebut menjadi penggugah kesadaran tentang bagaimana seharusnya menjalani hidup dan memikirkan makna dari tujuan penciptaan manusia. Manusa sebagai makhluk yang diberi kebebasan memilih cara hidupnya, ada yang menjalani hidup tanpa mencari dan memikirkan makna kehidupan itu sendiri, sehingga mereka tidak perlu memikirkan hidup sebagai hal yang sulit, dan sekedar menjalani hidup tanpa makna dan motivasi. Sebagian manusia ada yang berusaha untuk mengetahui makna kehidupannya. Hal ini mereka meyakini dapat membantu menjalani hidup dengan lebih baik, terarah dan bermakna.

Berdasarkan hal tersebut di atas, capaian pembelajaran pada bab ini diharapkan mahasiswa dapat memahami konsep ibadah, ibadah mahdhah dan ghairu mahdhah, fungsi dan hikmah ibadah, serta mampu 
mengaplikasikan makna spiritiual ibadah dalam kehidupan sosial.

\section{B. Penyajian Materi}

\section{Konsep Ibadah}

Secara bahasa, kata ibadah adalah bentuk dasar (mashdar) dari fi'il (kata kerja) يعبد - عبد yang berarti taat (الطاعة), tunduk (الخضّ), hina dan pengabdian $\left(\right.$ (النتسُُكُكُ). ${ }^{1}$ Berdasarkan pengertian ibadah secara bahasa tersebut, Zainuddin memberikan pengertian bahwa seseorang yang tunduk, patuh dan merendahkan diri dihadapan yang disembah disebut "abid" (yang beribadah). ${ }^{2}$ Hal ini Ibnu Taymiyah mengartikan ibadah sebagai puncak ketaatan dan ketundukkan yang di dalamnya terdapat unsur cinta. ${ }^{3}$ Selanjutnya, Syaikhul Islam Ibnu Taimiyah mengatakan:

${ }^{11}$ Yunasril Ali, 2009. Dasar-Dasar Ilmu Hukum. (Jakarta: Sinar Grafika, 2009), h. 17.

2 A. Rahman Ritonga Zainuddin, Fiqh Ibadah, (Jakarta: Gaya Media Pratama,1997), h. 1

${ }^{3}$ Ibn Taymiyah, al- 'Ubudiyyah, (Beirut: Darul Kutub alIlmiyah,1981),h. 44. 


$$
\begin{aligned}
& \text { في عبادة نظرا إلى المعرفة والمحبة والاستسلام لله. حتى في العبادة } \\
& \text { يحتوي على كل ما يحبه الله والمرح. النقطة المركزية والأكثر إلحاحا } \\
& \text { في قلوبنا كل أشكال الإيمان، وتعرفوا محبة الله والخوف وأتوب إليه، } \\
& \text { توكلت على ذلك، والقانون فرحة. ومن بين أشكال العبادة هي } \\
& \text { الصلاة، ذكرى، والصلاة وقراءة القرآن }
\end{aligned}
$$

"Dalam ibadah itu terkandung mengenal, mencintai, dan tunduk kepada Allah. Bahkan dalam ibadah terkandung segala yang Allah cintai dan ridhoi. Titik sentral dan yang paling urgen dalam segala yang ada adalah di hati yaitu berupa keimanan, mengenal dan mencintai Allah, takut dan bertaubat pada-Nya, bertawakkal pada-Nya, serta ridha terhadap hukumNya. Di antara bentuk ibadah adalah shalat, dzikir, do'a, dan membaca al-Qur'an."4

Imam Ibnu Katsir menjelaskan tentang pengertian ibadah menurut pengertian syari'at adalah:

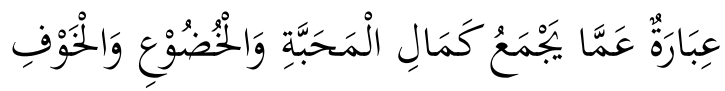

4 Ibn Taymiyah, Majmu' al-Fatawa, Li Ibnu Taimiyah, jilid 32, (Qahirah: Darul Hadits, 2006), h. 232. 
"suatu ungkapan yang memadukan antara kesempurnaan rasa cinta, ketundukan, dan rasa takut yang sempurna (kepada Allah)."

Sementara Hasbi As-Shiddiqi ${ }^{6}$, mengemukakan bahwa hakikat ibadah adalah:

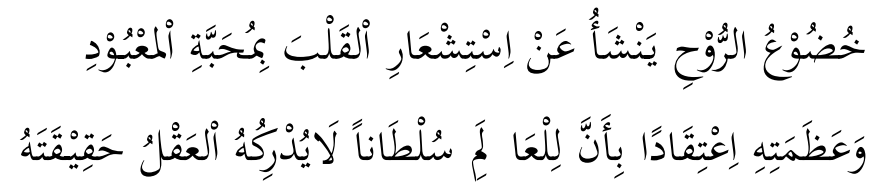

"Ketundukkan jiwa yang timbul dari hati yang merasakan cinta terhadap Tuhan yang disembah dan merasakan kebesarannya, meyakini bahwa bagi alam ini ada penguasanya, yang tidak dapat diketahui oleh akal hakikatnya."

Beribadah pada Allah SWT. dalam perspektif Islam merupakan harga mati. Pilihannya hanya ada dua, yaitu beribadah pada Allah atau beribadah kepada selainNya. Artinya, dalam beribadah kepada Allah tidak bisa dilakukan secara setengah-setengah atau mengabungkan keduanya, sehingga ketaatan, ketundukkan dan pengabdiannya hanya ditujukan kepada Allah saja serta berani mengingkari segala bentuk thaghut (tuhan selain-Nya).

5 Ibnu Katsir, Tafsir Al-Qur'anul 'adzim, (Beirut : al-Maktabah atTaufiqiyah, 1991), cet. I. h. 34.

${ }^{6}$ Hasbi As-Shiddiqie, Hukum Hukum Fikih Islam, (Jakarta: Bulan Bintang, 1991), h. 7-8. 
Selanjutnya mengapa manusia beribadah? Untuk menjawab pertanyaan ini, Allah SWT menjelaskan dan menyadarkan tentang tujuan penciptaan manusia dan tujuan hidupnya adalah hanyalah untuk beribadah kepadaNya. Hal ini Allah berfirman sebagai berikut:

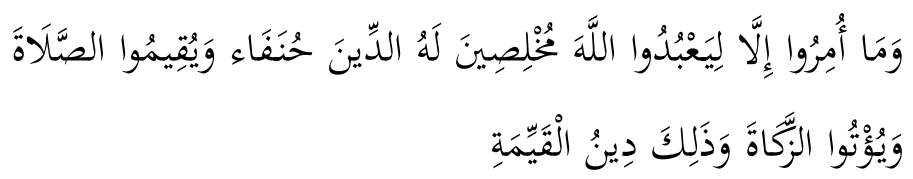

"Padahal mereka tidak disuruh kecuali supaya menyembah Allah dengan memurnikan ketaatan kepada-Nya dalam (menjalankan) agama yang lurus ${ }^{7}$, dan supaya mereka mendirikan shalat dan menunaikan zakat; dan yang demikian Itulah agama yang lurus. ${ }^{8}$

Berdasar ayat di atas, dapat menjadi hipotesa bahwa tujuan manusia hidup di bumi adalah untuk beribadah kepada Allah dengan memurnikan ketaatan kepadaNya. Oleh karena itu, Allah menggambarkan wujud ibadah yang sesunguhnya sebagaimana semboyan hidup yang diabadikan dalam firmanNya sebagai berikut:

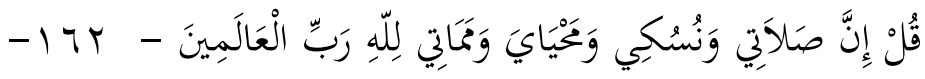

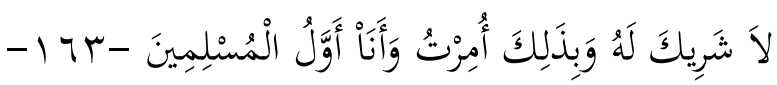

${ }^{7}$ Lurus berarti jauh dari syirik (mempersekutukan Allah) dan jauh dari kesesatan.

${ }^{8}$ QS. al-Bayyinah [98]:5, juga bisa dilihat pada QS. adz-Dzaariyaat [51]:56. 
"Katakanlah: Sesungguhnya sembahyangku, ibadatku, hidupku dan matiku hanyalah untuk Allah, Tuhan semesta alam. Tiada sekutu bagiNya; dan demikian itulah yang diperintahkan kepadaku dan aku adalah orang yang pertama-tama menyerahkan diri (kepada Allah)". ${ }^{9}$

Dari ayat di atas, seluruh aktivitas kebaikan, bernilai ibadah, jika aktivitas kebaikan tersebut semata-mata ditujukan dan dilakukan karena Allah semata-mata. Sedangkan terkait hakikat ibadah, masing-masing ulama dan ahli agama Islam memiliki pandangan sendiri-sendiri yang secara garis besar disimpulkan bahwa inti dan hakikat ibadah adalah puncak ketaatan ( غَائةُ الطَّاعَةِ), puncak ketundukkan

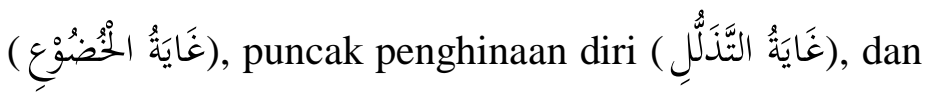
puncak pengabdian ( غَايَةُ التَنَسُشْكِ di hadapan Allah SWT. Keempat keadaan ini sebagai pilar-pilar beribadah kepada Allah semata dengan apa-apa yang telah disyari'atkanNya, sehingga pada akhirnya akan membawaibadah yang dilakukan sebagai tujuan hidupnya.

${ }^{9}$ QS. al-An'aam [6]:162-163. 


\section{Ibadah Mahdhah dan Ghairu Mahdhah}

Ditinjau dari segi ruang lingkupnya, ibadah dibagi menjadi dua bagian, yaitu: ibadah mahdhah atau ibadah khashshah (khusus) dan ibadah ghairu mahdhah atau ibadah 'Aamah (umum). Ibadah mahdhah adalah ibadah yang ketentuannya telah ditetapkan, memiliki aturan yang jelas dan terukur seperti digariskan Rasulullah SAW, seperti: thaharah (wudhu, tayamum dan mandi junub), shalat, zakat, puasa dan haji. Ibadah ghairu mahdhah berupa semua perbuatan baik yang dilakukan dengan niat karena Allah SWT semata, misalnya: berdakwah, melakukan amar ma'ruf nahi munkar di berbagai bidang, menuntut ilmu, bekerja, rekreasi dan lain-lain yang semuanya itu diniatkan semata-mata karena Allah SWT dan ingin mendekatkan diri kepadaNya.

Islam memberikan pedoman ibadah yang bersifat final, yaitu memberikan prinsip-prinsip ibadah sebagai berikut: ${ }^{10}$

${ }^{10}$ Ahmad Azhar Basyir, Falsafah Ibadah dalam Islam, (Yogyakarta: UII Press, 2006), 7. 
a. Beribadah hanya menyembah Allah sebagai sebagai wujud hanya mengesakan Allah. ${ }^{11}$

b. Ibadah tanpa perantara ${ }^{12}$

c. Ibadah dilakukan secara ikhlas, yakni niat murni semata hanya mengharap keridhaan Allah SWT. ${ }^{13}$

d. Ibadah harus sesuai tuntunan. ${ }^{14}$

\section{Fungsi dan Hikmah Ibadah dalam Kehidupan}

\section{Manusia}

Bentuk ritual dalam agama Islam memiliki tujuan dan fungsi dalam kehidupan manusia. Hakikat ibadah pada bahasan sebelumnya menjelaskan bahwa ibadah mahdhah merupakan perwujudan rasa tunduk, taat, patuh dan pengakuan oleh manusia terhadap kekuasaan Allah melalui pendekatan keillahian. Sedangkan ibadah ghairu mahdhah merupakan perwujudan keterikatan batin yang memiliki sifat rahman dan rahim Allah sebagai makhluk sosial, rasa tanggung jawab sebagai khalifah Allah di bumi yang diwujudkan oleh manusia dalam kehidupan sehari-

${ }^{11}$ QS. al-Fatihah [1]: 5, an-Nisaa' [4]: 36 dan an-Nahl [16]: 36.

${ }^{12}$ QS. al-Baqarah [2]: 186, Qaf [50]: 16, dan al-Hadid [57]: 4.

${ }^{13}$ QS. al-Bayyinah [98]: 5.

${ }^{14}$ QS. al-Hasyr [59]:7 
hari. Manusia beribadah kepada Allah, baik melalui ibadah mahdhah dan ghairu mahdhah bertujuan untuk mewujudkan hubungan antara manusia dengan Tuhannya, tetapi juga untuk mewujudkan hubungan antar sesama manusia. Dengan demikian, Islam mendorong manusia untuk beribadah kepada Allah SWT dalam semua aspek kehidupan dan aktifitas manusia sehari-hari.

Bahasan sub ini, difokuskan pada 5 (lima) aspek fungsi ibadah dalam kehidupan manusia, sebagai berikut:

a. Mewujudkan hubungan antara hamba dengan Tuhannya.

Mewujudkan hubungan antara manusia dengan Tuhannya dapat dilakukan melalui 15 مراقبة ${ }^{15}$ dengan Allah SWT. Muraqabatullah merupakan upaya diri untuk senantiasa merasa terawasi oleh Allah. Jadi upaya untuk menghadirkan muraqabatullah dalam diri dengan

15 Muraqabah artinya merasa selalu diawasi oleh Allah SWT sehingga dengan kesadaran ini mendorong manusia senantiasa rajin melaksanakan perintah dan menjauhi larangan-Nya. 
jalan mewaspadai dan mengawasi diri sendiri. ${ }^{16}$

Orang yang beriman dirinya akan selalu merasa diawasi oleh Allah. Ia akan selalu berupaya menyesuaikan segala perilakunya dengan ketentuan Allah SWT. Dengan sikap itu seseorang muslim tidak akan melupakan kewajibannya untuk beribadah, bertaubat, dan menyandarkan segala kebutuhannya pada pertolongan Allah SWT, sehingga manusia akan terbebas dari penghambaan terhadap manusia, harta benda dan hawa nafsu. Hal ini dicerminkan dengan ikrar seorang muslim seperti dalam firman Allah berikut:

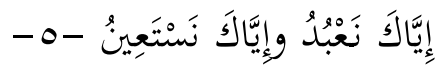

"Hanya Engkaulah yang kami sembah ${ }^{17}$, dan hanya kepada Engkaulah kami meminta pertolongan ${ }^{18,},{ }^{19}$

${ }^{16}$ Lihat QS al-Hadid: 4, QS ali Imran: 6 dan QS Ghafir: 19.

${ }^{17} \mathrm{Na}$ 'budu diambil dari kata 'ibaadat: kepatuhan dan ketundukkan yang ditimbulkan oleh perasaan terhadap kebesaran Allah, sebagai Tuhan yang disembah, karena berkeyakinan bahwa Allah mempunyai kekuasaan yang mutlak terhadapnya. 
Fungsi ibadah dalam kehidupan manusia dapat dipahami sebagai sarana untuk menghubungkan diri kita dengan Allah SWT dan untuk membuktikan diri kita sebagai hamba serta sekaligus untuk menegaskan keberadaan Allah SWT.

b. Membentengi manusia dari perbuatan keji dan mungkar

Fungsi ibadah dalam kehidupan manusia juga dapat membentenggi manusia dari perbuatan keji dan mungkar. Sebagaimana yang dikemukakan dalam firman Allah berikut:

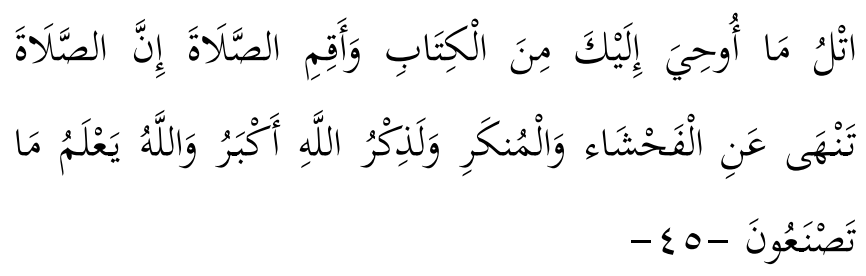

${ }^{18}$ Nasta'iin (minta pertolongan), terambil dari kata isti'aanah: mengharapkan bantuan untuk dapat menyelesaikan suatu pekerjaan yang tidak sanggup dikerjakan dengan tenaga sendiri.

${ }^{19}$ QS. al-Faatihah [1]: 5. 
"Bacalah apa yang telah diwahyukan kepadamu, yaitu al-kitab (al-Qur'an) dan dirikanlah shalat. Sesungguhnya shalat itu mencegah dari (perbuatan- perbuatan) keji dan mungkar. dan sesungguhnya mengingat Allah (shalat) adalah lebih besar (keutamaannya dari ibadat-ibadat yang lain) dan Allah mengetahui apa yang kamu kerjakan", ${ }^{20}$

Ayat di atas, memberi makna bahwa ibadah (shalat) yang berkualitas akan menjauhkan kita dari perbuatan maksiat. Dengan demikian, apabila seseorang melakukan kebaikan dan rajin shalat namun perbuatan maksiat masih juga tetap menghiasi hidupnya, maka hal ini menandakan bahwa ibadahnya tidak berkualitas atau justru ditolak. Hal in disebabkan oleh seseorang menjalankan ibadah tapi tidak berimplikasi dalam kehidupannya sehari-hari.

${ }^{20}$ QS. al-'Ankabuut [29]: 45. 
c. Mendidik solidaritas dengan sesama manusia lainnya

Ibadah juga berfungsi sebagai upaya mendidik mental manusia, sehingga tumbuh rasa tanggungjawab terhadap hak dan kewajiban untuk menerima dan memberi nasihat. Ibadah-ibadah maghdah dalam Islam selalu dihubungkan dengan kehidupan sosial. Artinya, ibadah yang dilakukan, harus membawa dampak sosial. Misalnya tentang ibadah (zakat), sebagaimana firman Allah berikut:

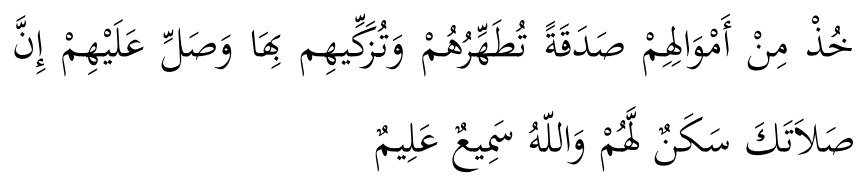

"Ambillah zakat dari sebagian harta mereka, dengan zakat itu kamu membersihkan dan mensucikan mereka dan mendoalah untuk mereka. Sesungguhnya doa kamu itu (menjadi) ketenteraman jiwa bagi mereka dan Allah Maha mendengar lagi Maha mengetahui." 21

${ }^{21}$ QS. at-Taubah [9]: 103 
Ayat di atas, mengandung spirit filantropi (kedermawanan) dalam Islam. Dua nilai penting yang terkandung dalam spirit ayat filantropi di atas adalah bahwa zakat dan selalu mengandung dimensi ganda. Dimensi kesalehan individual tercermin dalam tazkiyat an nufus dalam zakat (penyucian dan pembersihan diri dan harta) pada satu sisi, dan refleksi kesalehan sosial pada sisi lain seperti empati dan solidaritas pada sisi yang lain.

d. Melatih disiplin

Ibadah menuntut kita untuk berdisiplin. Kenyataan ini ditunjukkan dengan jelas dalam pelaksanaan shalat, mulai dari wudhu, ketentuan waktunya, berdiri, ruku, sujud dan aturan-aturan lainnya, mengajarkan kita untuk berdisiplin. Misalnya, dalam shalat kita dituntut untuk fokus dan selalu tepat waktu sehingga akan menumbuhkan rasa disiplin bagi setiap individu yang melaksanakan shalat.

Dengan demikian, ibadah yang dikerjakan dengan baik dan benar, sesuai dengan tuntunan 
Allah SWT dan RasulNya berimplikasi pada kebaikan kepada sesama lainnya. Seperti menebar kebaikan kepada orang tua, suami, istri, anakanak, saudara kandung, dan saudara sesama muslim, para tetangga, fakir miskin, anak yatim, memenuhi hajat orang lain, serta mencegah diri dari perbuatan keji dan mungkar seperti, berselingkuh, menyakiti saudara kandung dan saudara sesama muslim, membiarkan fakir miskin kelaparan, mencuri, merampok, menyuap, korupsi, berzina, iri hati, dusta, berkhianat, mengambil hak orang lain tanpa izin, menyalahgunakan jabatan, dan seterusnya.

e. Mendekatkan diri dengan Allah SWT

Ibadah ritual umat Islam, merupakan sarana kita mendekatkan diri kepada Allah. Misalnya, ibadah (sholat), diingatkan akan dekatnya Allah kepada kita, sehingga membuat umat muslim semakin mendekatkan diri kepada Allah. Hal ini sebagaimana firman Allah SWT berikut: 


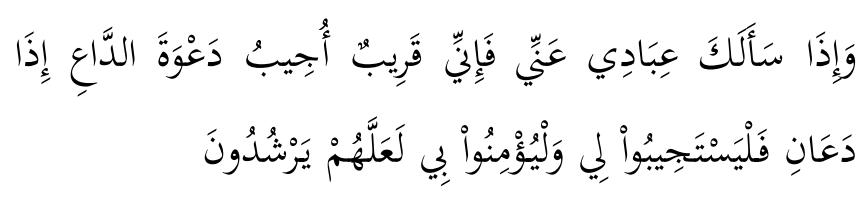

"Dan apabila hamba-hamba-Ku bertanya kepadamu tentang Aku, maka (jawablah), bahwasanya aku adalah dekat. aku mengabulkan permohonan orang yang berdoa apabila ia memohon kepada-Ku, maka hendaklah mereka itu memenuhi (segala perintah-Ku) dan hendaklah mereka beriman kepada-Ku, agar mereka selalu berada dalam kebenaran". 22

Adapun hikmah disyariatkannya ibadah dalam kehidupan manusia, sebagaimana yang Allah SWT. tegaskan dalam firman-Nya:

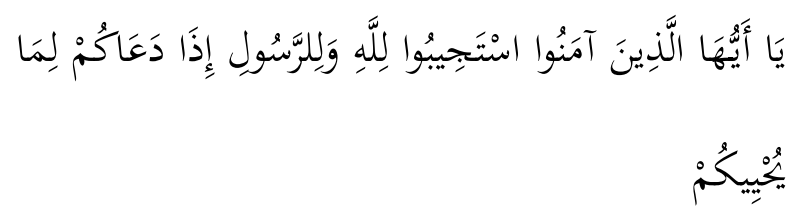

"Hai orang-orang beriman, penuhilah seruan Allah dan seruan Rasul-Nya yang mengajak kamu

${ }^{22}$ QS. al-Baqarah [2]: 186 
kepada suatu yang memberi (kemaslahatan) hidup bagimu". 23

Ayat di atas, menunjukkan bahwa kebaikan dan kemashlahatan merupakan sifat yang selalu ada pada semua ibadah dan petunjuk yang diserukan oleh Allah dan Rasul-Nya SAW. Ayat tersebut juga menjelaskan manfaat dan hikmah besar dari semua ibadah yang Allah SWT syariatkan kepada kehidupan manusia, yaitu bahwa bersih dan sucinya hati dan jiwa manusia, yang merupakan sumber kebaikan dalam dirinya, hanyalah bisa dicapai dengan beribadah kepada Allah SWT. melalui ketaatan kepada-Nya dan kepada Rasul-Nya SWT.

Beberapa hikmah ibadah dalam kehidupan manusia, antara lain:

1) Terbebas dari kesyirikan. Hal ini sesuai firman Allah:

$$
\text { .... }
$$

${ }^{23}$ QS. al-Anfâl [8]:24 
“...dan melainkan bersujudlah kepada Allah, yang telah menciptakan mereka, jika kamu benar-benar hanya kepada Nya kamu menyembah (beribadah)". ${ }^{24}$

Ayat ini mengajarkan kepada kita, bahwa seorang hamba yang sudah berketapan hati untuk senantiasa beribadah menyembah kepada Nya, maka ia harus meninggalkan segala bentuk syirik. Ia telah mengetahui segala sifat-sifat yang dimiliki Nya adalah lebih besar dari segala yang ada, sehingga tidak ada wujud lain yang dapat mengungguli Nya dan dapat dijadikan tempat bernaung.

2) Menggapai ketakwaan. Allah berfirman:

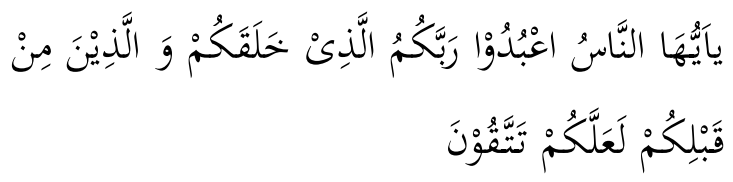

"Hai manusia, sembahlah Tuhan mu yang telah menjadikan kamu dan juga orang-orang sebelummu supaya kamu bertakwa". 25

${ }^{24}$ QS. Fushshilat [41]: 37

${ }^{25}$ QS. al-Baqarah [2]: 21 
Ada dua hal yang melandasi manusia menjadi bertakwa, yaitu karena cinta atau karena takut. Ketakwaan yang dilandasi cinta timbul karena ibadah yang dilakukan manusia setelah merasakan kemurahan dan keindahan Allah SWT. Setelah manusia melihat kemurahan dan keindahan Nya munculah dorongan untuk beribadah kepada Nya. Sedangkan ketakwaan yang dilandasi rasa takut timbul karena manusia menjalankan ibadah dianggap sebagai suatu kewajiban bukan sebagai kebutuhan. Ketika manusia menjalankan ibadah sebagai suatu kewajiban adakalanya muncul ketidak ikhlasan, terpaksa dan ketakutan akan balasan dari pelanggaran karena tidak menjalankan kewajiban.

3) Terhindar dari kemaksiatan. Allah berfirman:

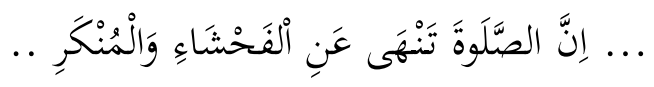

"Sesungguhnya shalat mencegah orang dari kekejian dan kejahatan yang nyata". ${ }^{26}$

${ }^{26}$ QS. al-'Ankabuut [29]: 45 
Ibadah memiliki daya pensucian yang kuat sehingga dapat menjadi tameng dari pengaruh kemaksiatan, tetapi keadaan ini hanya bisa dikuasai jika ibadah yang dilakukan berkualitas. Ibadah ibarat sebuah baju yang harus selalu dipakai dimanapun manusia berada.

4) Menumbuhkan jiwa sosial. Ibadah menjadikan seorang hamba menjadi lebih peka dengan keadaan lingkungan disekitarnya, karena dia mendapat pengalaman langsung dari ibadah yang dikerjakannya. Sebagaimana ketika melakukan ibadah puasa, ia merasakan rasanya lapar yang biasa dirasakan orangorang yang kekurangan. Sehingga mendorong hamba tersebut lebih memperhatikan orangorang dalam kondisi ini.

5) Mengikis sifat kikir.

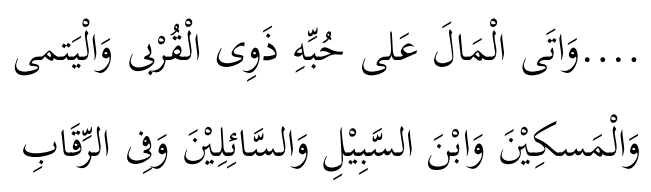


"Dan karena cinta kepada Nya memberikan harta benda kepada ahli kerabat, dan anak-anak yatim, dan orang-orang miskin, dan kaum musafir, dan mereka yang meminta sedekah dan untuk memerdekakan sahaya.",27

Harta yang dimiliki manusia pada dasarnya bukan miliknya tetapi milik Allah SWT yang seharusnya diperuntukan untuk kemaslahatan umat. Tetapi karena kecintaan manusia yang begita besar terhadap keduniawian menjadikan dia lupa dan kikir akan hartanya. Berbeda dengan hamba yang mencintai Allah SWT, senantiasa dawam menafkahkan hartanya di jalan Allah SWT, ia menyadari bahwa miliknya adalah bukan haknya tetapi ia hanya memanfaatkan untuk keperluanya semata-mata sebagai bekal di akhirat yang diwujudkan dalam bentuk pengorbanan harta untuk keperluan umat.

6) Merasakan keberadaan Allah SWT. Ketika seorang hamba beribadah, Allah SWT benar-

${ }^{27}$ QS. al-Baqarah [2]: 177 
benar berada berada dihadapannya, maka harus dapat merasakan/melihat kehadiran Nya atau setidaknya dia tahu bahwa Allah SWT sedang memperhatikannya.

7) Meraih martabat liqa Illah. Allah berfirman:

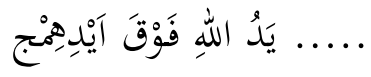

“...Tangan Allah ada di atas tangan mereka". ${ }^{28}$

Melalui ibadah yang dilakukannya, seorang hamba meleburkan diri dalam sifatsifat Allah SWT, menghanguskan seluruh hawa nafsunya dan lahir kembali dalam kehidupan baru yang dipenuhi ilham Ilahi. Dalam martabat ini manusia memiliki pertautan dengan Tuhan yaitu ketika manusia seolah-olah dapat melihat Tuhan dengan mata kepalanya sendiri. Sehingga segala inderanya memiliki kemampuan batin yang sangat kuat memancarkan daya tarik kehidupan suci. Allah SWT menjadikan mata manusia yang dengan itu ia melihat, menjadi lidahnya yang

${ }^{28}$ QS. al-Fath [48]: 10. 
dengan itu ia bertutur kata, menjadi tangannya yang dengan itu ia memegang, menjadi telinganya yang dengan itu ia mendengar, menjadi kakinya yang dengan itu ia melangkah.

8) Menjadi sebab terkabul doa-doanya. Allah berfirman:

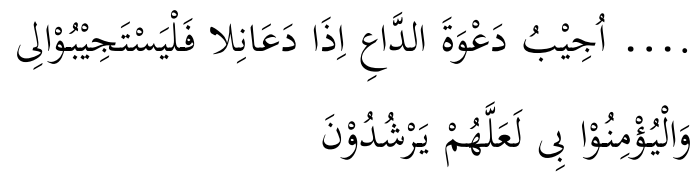

“...Aku mengabulkan doa orang yang memohon apabila ia mendoa kepada $\mathrm{Ku}$. Maka hendaklah mereka menyambut seruan $\mathrm{Ku}$ dan beriman kepada $\mathrm{Ku}$ supaya mereka mengikuti jalan yang benar". ${ }^{29}$

9) Menumbuhkan kejujuran. Allah berfirman:

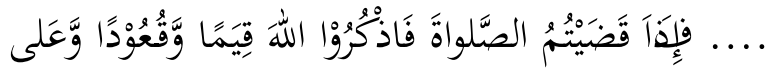

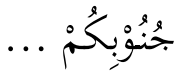

${ }^{29}$ QS. al-Baqarah [2]: 186 
“.....Dan apabila kamu telah selesai mengerjakan shalat, maka ingatlah kepada Allah sambil berdiri, sambil duduk dan sambil berbaring atas rusuk kamu...... ${ }^{30}$

Ibadah berarti berdzikir (ingat) kepada Allah SWT, hamba yang menjalankan ibadah berarti ia selalu ingat Allah SWT dan merasa bahwa Allah SWT selalu mengawasinya sehingga tidak ada kesempatan untuk berbohong. Hal ini sesuai riwayat hadits:

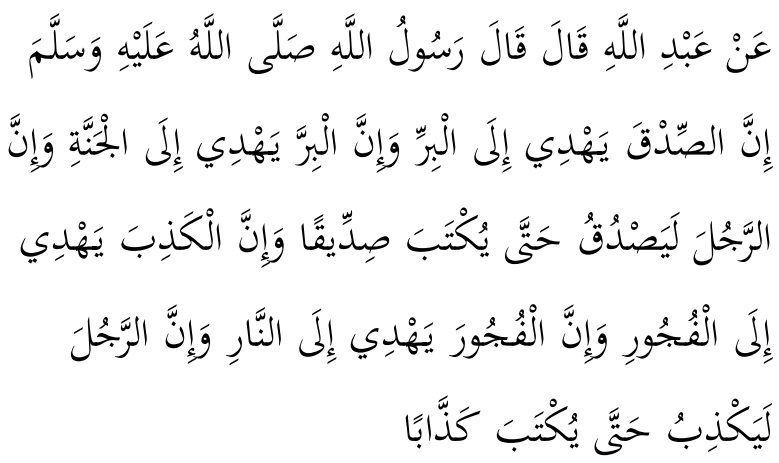

"Dari 'Abdullah dia berkata; Rasulullah shallallahu 'alaihi wasallam bersabda: "Sesungguhnya kejujuran itu akan

${ }^{30}$ QS. an-Nisaa' [4]: 103 
membimbing pada kebaikan. Dan kebaikan itu akan membimbing ke surga. Seseorang yang senantiasa berlaku jujur maka ia akan dicatat sebagai orang yang jujur. Dan sesungguhnya dusta itu akan mengantarkan pada kejahatan. Dan sesungguhnya kejahatan itu akan menggiring ke neraka. Seseorang yang memelihara kedustaan, maka ia akan dicatat sebagai pendusta." 31

10) Berhati ikhlas. Allah berfirman:

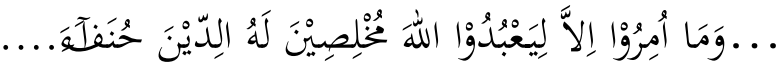

"Dan mereka tidak diperintahkan melainkan supaya beribadah kepada Allah dengan tulus ikhlas dalam ketaatan kepada Nya dengan lurus." 32

11) Melatih kedisiplinan. Ibadah harus dilakukan dengan دائمون dawam (rutin dan teratur),

${ }^{31}$ HR. Muslim: 4719.

${ }^{32}$ QS. al-Bayyinah [98]: 5. 
خاثشعون khusyu (sempurna), يحافظون terjaga dan semangat.

12) Menjadikan sehat jasmani dan rohani. Seorang hamba yang beribadah menjadikan gerakan shalat sebagai senamnya, puasa menjadi sarana diet yang sehat, membaca alQur'an sebagai sarana terapi kesehatan mata dan jiwa. Insya Allah hamba yang tekun dalam ibadah dikaruniakan kesehatan.

\section{Makna Spiritiual Ibadah Bagi Kehidupan Sosial}

Bahasan tentang makna spiritual ibadah difokuskan pada 4 (empat) ibadah, yaitu ibadah shalat, ibadah puasa, ibadah maaliyah (harta), dan ibadah haji. Makna spiritual masing-masing ibadah tersebut dalam kehidupan sosial dipaparkan sebagai berikut:

a. Nilai-nilai spiritual ibadah shalat

Nilai-nilai spiritual yang terkandung di dalam shalat diantaranya: (1) mendekatkan dan mengingatkan manusia kepada Tuhannya; shalat dapat mendidik untuk senantiasa menjaga kesucian fitrah; (3) mendidik untuk berlaku jujur; (4) mencegah pelakunya dari perbuatan keji dan 
mungkar ${ }^{33}$; (5) membina rasa persatuan dan persaudaraan antara sesama umat Islam; dan (6) shalat sebagai penebus dosa sebagaimana dijelaskan dalam hadits berikut:

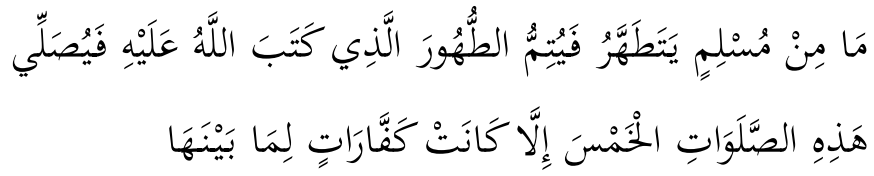

"Tidaklah seorang muslim pun bersuci lalu menyempurnakan bersucinya sebagimana Allah telah mewajibkan kepadanya, lalu melakukan shalat lima waktu melainkan itu menjadi penebus dosa antara keduanya." ${ }^{34}$

b. Nilai-nilai spiritual ibadah puasa

1) Puasa dan kebersihan jiwa. Membersihkan jiwa dalam berpuasa berarti manusia menjalankan dan mentaati seluruh perintah dan larangan Allah dengan cara menahan diri dari hal-hal yang terlarang dan membatalkan puasa.

2) Meningkatkan kesabaran. Puasa mendidik dalam mengendalikan hawa nafsu, membiasakan bersikap sabar dalam ketaatan dan menghadapi musibah.

${ }^{33}$ QS. al-‘Ankabuut [29]: 45

${ }^{34}$ HR. Muslim:338 
3) Menumbuhkan sikap syukur kepada Allah atas limpahan rahmatNya. Hal ini digambarkan ketika berbuka, maka hati dan lisannya muncul keinginan untuk mengucapkan "alhamdulillah" sebagai pancaran jiwanya untuk mensyukuri nikmat-nikmat Allah yang telah dianugerahkan kepadanya.

4) Puasa mendidik menjadi manusia yang ikhlas dalam beramal.

5) Puasa dapat melatih kepedulian atau empati

6) Puasa dapat menyehatkan fungsi tubuh manusia (صوموا تصحوا) ( ) (ص)

c. Nilai-nilai spiritual ibadah maaliyah (harta)

Nilai-nilai spiritual ibadah maaliyah dalam kehidupan manusia merupakan merefleksikan nilai spiritual dan nilai charity (kedermawanan) atau filantropi dalam Islam. Sejumlah ayat bertebaran dalam berbagai surat dalam al-Qur'an dan hadits Nabi ditemukan anjuran tentang pentingnya filantropi terhadap sesama manusia, di antaranya: QS. ar-Ruum [30]:39; dan QS. at-Taubah [9]: 103. Dua Ayat tersebut, mengandung spirit filantropi 
dalam Islam. Dua nilai penting yang terkandung dalam spirit ayat filantropi adalah bahwa ibadah maaliyah dan selalu mengandung dimensi ganda. Dimensi kesalehan individual tercermin dalam tazkiyat an nufus dalam zakat (penyucian dan pembersihan diri dan harta) pada satu sisi, dan refleksi kesalehan sosial pada sisi lain seperti empati dan solidaritas pada sisi yang lain.

Ibadah maaliyah sebagai media tazkiyat an nufus dalam konteks di atas diungkapkan dalam dua istilah yaitu membersihkan dan menyucikan. Membersihkan mengandung makna bahwa ibadah maaliyah itu membersihkan muzakki (orang yang mengeluarkan zakat) dari sifat kikir dan cinta yang berlebih-lebihan kepada harta benda. Menyucikan mengandung makna bahwa ibadah maaliyah memiliki satu kekuatan transformatif dalam menyuburkan sifat-sifat kebaikan dalam hati muzakki dan harta benda yang mereka kembangkan menjadi suci disebabkan terbayarbayarnya hak-hak orang lain yang melekat di dalamnya. 
Nilai filantropi ibadah maaliyah lainnya adalah kepedulian dan keadilan sosial kepada sesama manusia, terutama kepada mereka (asnaf) yang menjadi sasaran (target group) filantropi dalam Islam, yaitu orang-orang fakir, orang-orang miskin, pengurus-pengurus zakat, para mu'allaf yang dibujuk hatinya, untuk (memerdekakan) budak, orang-orang yang berhutang, untuk jalan Allah dan untuk mereka yang sedang dalam perjalanan.

d. Nilai-nilai spiritual ibadah haji

1) Ibadah haji sebagai manifestasi ketundukan manusia kepada Allah SWT. semata.

2) Haji sebagai ta'zhim (membesarkan) syi'ar Allah SWT.

3) Menunaikan ibadah haji sebagai tadabbur (mengambil pelajaran).

4) Ibadah haji sebagai rihlah muqaddasah (perjalanan suci). Perjalanan haji pada hakekatnya adalah perjalanan suci yang semua rangkaian kegiatannya adalah merupakan ibadah. 
Pertama, thawaf yaitu mengitari Ka'bah sebanyak tujuh kali melawan arah jarum jam. Thawaf adalah simbol bahwa alam ini tidak berhenti bergerak. Ini dilambangkan dengan mengelilingi Kakbah. Manusia yang ingin eksis adalah yang manusia yang selalu bergerak. Maknanya, bergerak adalah entitas kehidupan, sebab berhenti bergerak sama dengan kematian. Kualitas seseorang ditentukan oleh bergeraknya ia ke arah yang memberi gerak. Bergerak ke pusat orbitnya. Bergerak dalam mengejewantahkan nilai-nilai ketuhanan di muka bumi.

Kedua, ritual sa'i. Sa'i yaitu berlari-lari kecil antara bukit Safa dan Marwa. menggambarkan tentang hidup perlu usaha, usaha yang sungguh-sungguh dan maksimal, tanpa mengenal putus asa.

Ketiga, melontar jumrah. Ibadah yang didasarkan kepada perilaku Nabi Ibrahim as yang melempar setan ketika ia ingin menunaikan perintah Allah SWT. Setan adalah 
simbol menggagalkan manusia untuk mentaati Allah. Oleh karenanya, dilawan dan dikeluarkan dari diri manusia.

Keempat, wukuf di Padang Arafah. Sejarah Islam mencatat di daerah inilah dipertemukannya Nabi Adam as dan Siti Hawa, yang kemudian melakukan taubat kepada Allah SWT sebagaimana firman-Nya berikut:

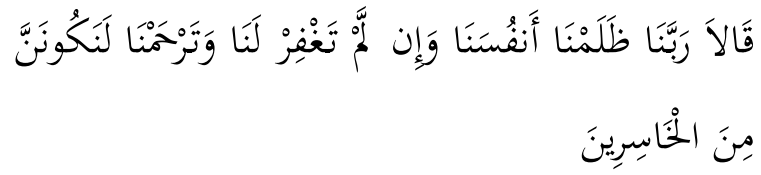

"Keduanya berkata: "Ya Tuhan Kami, Kami telah Menganiaya diri Kami sendiri, dan jika Engkau tidak mengampuni Kami dan memberi rahmat kepada Kami, niscaya pastilah Kami Termasuk orangorang yang merugi".3

\section{Rangkuman}

1. Ibadah adalah bentuk dasar (mashdar) yang berarti taat (الطاعة), tunduk (الخضل), hina dan

${ }^{35}$ QS. al-'Araaf [7]:23 


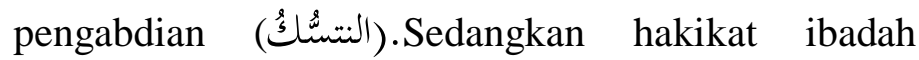
merupakan puncak ketaatan ( غَايَةُ الطَّاعَةِّ), puncak ketundukkan ( غَائُة الْنْضُوِْع), puncak penghinaan diri

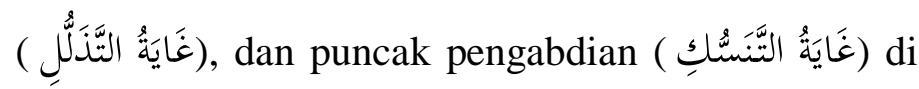
hadapan Allah SWT. Keempat keadaan ini sebagai pilar-pilar beribadah kepada Allah semata dengan apa-apa yang telah disyari'atkanNya, sehingga pada akhirnya akan membawa ibadah yang dilakukan sebagai tujuan hidupnya.

2. Ditinjau dari segi ruang lingkupnya, terdapat ibadah mahdhah atau ibadah khashshah (khusus) dan ibadah ghairu mahdhah atau ibadah 'Aamah (umum). Islam memberikan pedoman ibadah yang bersifat final, yaitu memberikan prinsip, yaitu: beribadah hanya menyembah Allah sebagai sebagai wujud hanya mengesakan Allah, beribadah tanpa perantara, beribadah dilakukan secara ikhlas, dan beribadah sesuai tuntunan syariat.

3. Fungsi ibadah dalam kehidupan manusia, di antaranya: (1) mewujudkan hubungan antara hamba 
dengan Tuhannya; (2) membentengi manusia dari perbuatan keji dan mungkar; (3) mendidik solidaritas dengan sesama manusia lainnya; (4) melatih disiplin; dan (5) mendekatkan diri dengan Allah SWT. Sedangkan hikmah ibadah dalam kehidupan manusia, antara lain: (1) terbebas dari kesyirikan; (2) menggapai ketakwaan; (3) terhindar dari kemaksiatan; (4) menumbuhkan jiwa sosial; (5) mengikis sifat kikir; (6) merasakan keberadaan Allah SWT; (7) meraih martabat liqa Illah; (8) menjadi sebab terkabul doa-doanya; (9) menumbuhkan kejujuran; (10) berhati ikhlas; (11) melatih kedisiplinan; dan (12) menjadikan sehat jasmani dan rohani.

4. Makna spiritual ibadah difokuskan pada 4 (empat) ibadah, yaitu ibadah shalat, ibadah puasa, ibadah maaliyah (harta), dan ibadah haji. Pertama, nilai-nilai spiritual ibadah shalat mendekatkan dan mengingatkan manusia kepada Tuhannya; (2) shalat dapat mendidik untuk senantiasa menjaga kesucian fitrah; (3) mendidik untuk berlaku jujur; mencegah pelakunya dari perbuatan keji dan mungkar; (5) membina rasa persatuan dan 
persaudaraan antara sesama umat Islam; dan (6) shalat sebagai penebus dosa. Kedua, nilai-nilai spiritual ibadah puasa: membersihkan jiwa, menumbuhkan kesabaran, sikap syukur dan ikhlas, melatih kepedulian atau empati, dan menyehatkan jasmani dan rohani. Ketiga, nilai-nilai spiritual ibadah maaliyah dalam kehidupan manusia merupakan merefleksikan nilai spiritual dan nilai charity (kedermawanan) yang memiliki fungsi ganda, yaitu tazkiyat an nufus (penyucian dan pembersihan diri dan harta) dan refleksi kesalehan sosial. Keempat, nilai-nilai spiritual ibadah haji, antara lain: ibadah haji sebagai manifestasi ketundukan manusia kepada Allah SWT, sebagai ta'zhim syi 'ar Allah SWT, sebagai tadabbur, dan ibadah haji sebagai rihlah muqaddasah (perjalanan suci).

\section{Latihan/Tugas/Eksperimen}

Evaluasi dalam bentuk penugasan: mengindentifikasi makna spiritual thaharah dan shalat (bacaan dan gerakannya) dalam kehidupan sehari-hari. 


\section{Daftar Pustaka}

Ali, Yunasril, 2009. Dasar-Dasar Ilmu Hukum. Jakarta: Sinar Grafika, 2009.

As-Shiddiqie, Hasbi, Hukum Hukum Fikih Islam, Jakarta: Bulan Bintang, 1991.

Basyir, Ahmad Azhar, Falsafah Ibadah dalam Islam, Yogyakarta:

UII Press, 2006.

Departemen Agama RI, Al-Qur'an dan Tafsirnya, Jakarta: Departemen Agama RI, 2010.

Katsir, Ibnu, Tafsir Al-Qur'anul 'adzim, Beirut : al-Maktabah atTaufiqiyah, 1991.

Taymiyah, Ibn, al-'Ubudiyyah, Beirut: Darul Kutub alIlmiyah, 1981. , Majmu' al-Fatawa, Li Ibnu Taimiyah, jilid 32, Qahirah: Darul Hadits, 2006.

Zainuddin, A. Rahman Ritonga, Fiqh Ibadah, Jakarta: Gaya Media Pratama, 1997. 


\section{BAB II}

SHALAT DAN MAKNA SPIRITUAL SHALAT

\section{A. Pendahuluan}

Shalat sebagai salah satu rukun Islam, menempati kedudukan istimewa dalam syariat Islam untuk membuktikan komitmen keimanan dan keislaman seseorang. Shalat adalah ibadah yang pertama kali diwajibkan oleh Allah SWT dan perintahnya langsung diterima oleh Rasulullah SAW. Agama Islam juga menempatkan shalat sebagai amalan pertama yang akan diperhitungkan terlebih dahulu, sebelum amalan-amalan yang lain. Sesorang dikatakan berhasil dalam menjalan ibadah shalat, tidak hanya diukur dalam menegakkan shalat tersebut, tetapi penilaiannya juga diukur seberapa besar shalatnya berimplikasi dalam kehidupan sosialnya.

Berdasarkan alasan teologi inilah, menjadi urgen memahami shalat dan makna spiritual shalat dalam kehidupan sehari-hari untuk menemukan rahasia keagungan spiritual, mental, dan fisik di balik gerakangerakan serta bacaan shalat yang dilakukan. Oleh karena itu, capaian pembelajaran pada materi ini adalah mahasiswa dapat memahami hakikat shalat, tujuan dan 
fungsi shalat, akhlaq shalat serta mampu mengambil 'ibrah (pelajaran) dari spirit gerakan dan bacaan di balik ibadah shalat, sehingga dapat melaksanakan shalat secara khusu', bukan sekedar gerakan mati yang kehilangan spirit dan pengaruhnya dalam kehidupan sehari-hari.

\section{B. Penyajian Materi}

Penyajian materi disesuaikan urutan bahasan dengan diawali tentang pengertian shalat, kewajiban shalat, tujuan dan fungsi shalat, akhlaq dalam shalat, ancaman bagi yang meninggalkan shalat dan diakhiri bahasan tentang makna spiritual ibadah shalat dalam kehidupan manusia.

\section{Pengertian Shalat}

Shalat secara bahasa berarti doa (الدعاء) atau rahmat. ${ }^{36}$ Secara terminologis, shalat memiliki pengertian sebagai berikut:

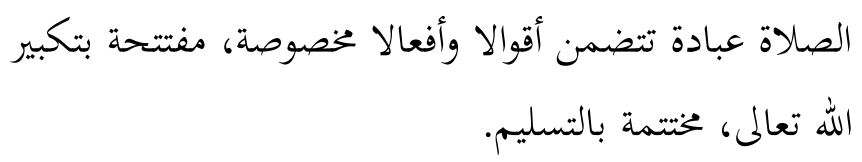

${ }^{36}$ QS. at-Taubah [9]: 103 dan QS. Al-Ahzab [33]: 43. 
"Shalat adalah ibadah yang mengandung di dalamnya ucapan dan perbuatan tertentu yang dimulai dengan takbir dan ditutup dengan salam.

Pengertian shalat di atas, menjelaskan makna shalat secara umum dan tidak dibatasi pada pengertian shalat tertentu. Oleh karenanya, yang dimaksudkan istilah shalat pada bab ini adalah shalat fardlu 5 (lima) waktu, yakni shalat Isya', Subuh, Dhuhur, Ashar dan Maghrib.

Ibadah shalat dalam Islam mempunyai arti penting dan kedudukan yang sangat istimewa, antara lain:

a. Shalat adalah ibadah pertama kali diwajibkan oleh Allah SWT yang perintahnya langsung diterima Rasulullah SAW pada malam Isra'-Mi'raj. ${ }^{38}$

b. Shalat adalah tiang agama

Kedudukan shalat sebagai tiang agama didasarkan pada riwayat hadits berikut:

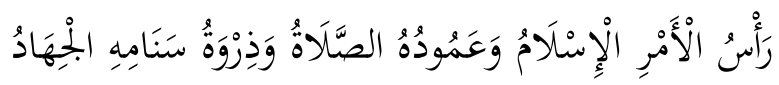

${ }^{37}$ Sayyid Sabiq, Fiqih Sunnah jilid 1, (Jakarta, Pena Pundi Aksara, 2006), h.90.

${ }^{38}$ QS. al-Israa' [17]: 1. 
"Pokok dari perkara agama adalah Islam, tiangnya adalah shalat, sedangkan puncaknya adalah jihad". 39

c. Shalat merupakan amalan yang pertama kali dihisab pada hari kiamat

Hal ini didasarkan pada hadits berikut:

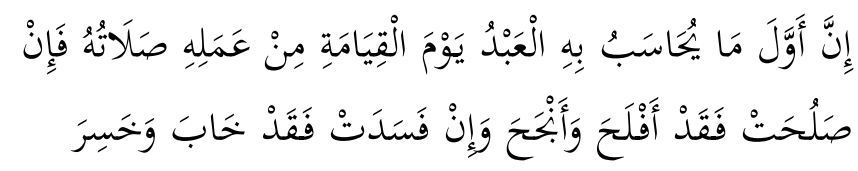

"Pada hari kiamat pertama kali yang akan Allah hisab atas amalan seorang hamba adalah shalatnya, jika shalatnya baik maka ia akan beruntung dan selamat, jika shalatnya rusak maka ia akan rugi dan tidak beruntung".

\section{Kewajiban Shalat}

Beberapa dasar pijakan dari nash (al-Qur'an dan al-Hadits) tentang perintah akan kewajiban mendirikan shalat fardhu 5 (lima) waktu. Dalil tentang shalat antara lain:

a. QS. an-Nisaa' [4]:103

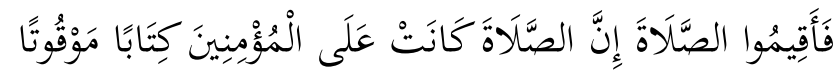
"...maka dirikanlah shalat itu (sebagaimana biasa).

Sesungguhnya shalat itu adalah kewajiban yang

${ }^{39}$ HR. at-Timirdzi: 2541

${ }^{40}$ HR. Tirmidzi: 378 
ditentukan waktunya atas orang-orang yang beriman."

b. QS. al-Baqarah [2]: 3

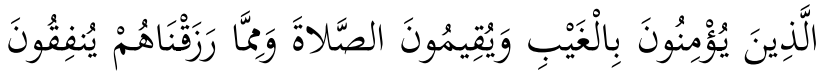
“(yaitu) mereka yang beriman ${ }^{41}$ kepada yang ghaib $^{42}$, yang mendirikan shalat ${ }^{43}$, dan menafkahkan sebahagian rezki ${ }^{44}$ yang Kami anugerahkan kepada mereka".

c. QS. Thahaa [20]: 14

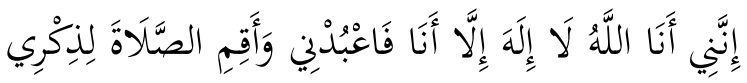

41 Iman ialah kepercayaan yang teguh yang disertai dengan ketundukan dan penyerahan jiwa. tanda-tanda adanya iman ialah mengerjakan apa yang dikehendaki oleh iman itu.

${ }^{42}$ Iman kepada yang ghaib ialah yang tak dapat ditangkap oleh pancaindera. percaya kepada yang ghjaib yaitu, mengi'tikadkan adanya sesuatu yang maujud yang tidak dapat ditangkap oleh pancaindera, karena ada dalil yang menunjukkan kepada adanya, seperti: adanya Allah, malaikat-malaikat, hari akhirat dan sebagainya.

${ }^{43}$ Shalat menurut bahasa 'Arab: doa. menurut istilah syara' ialah ibadat yang sudah dikenal, yang dimulai dengan takbir dan disudahi dengan salam, yang dikerjakan untuk membuktikan pengabdian dan kerendahan diri kepada Allah. mendirikan shalat ialah menunaikannya dengan teratur, dengan melangkapi syarat-syarat, rukun-rukun dan adabadabnya, baik yang lahir ataupun yang batin, seperti khusu', memperhatikan apa yang dibaca dan sebagainya.

$44 \quad 44$ Rezki adalah segala yang dapat diambil manfaatnya. menafkahkan sebagian rezki, ialah memberikan sebagian dari harta yang telah direzkikan oleh Tuhan kepada orang-orang yang disyari'atkan oleh agama memberinya, seperti orang-orang fakir, orang-orang miskin, kaum kerabat, anak-anak yatim dan lain-lain. 
"Sesungguhnya Aku ini adalah Allah, tidak ada Tuhan (yang hak) selain Aku, maka sembahlah Aku dan dirikanlah shalat untuk mengingat Aku."

Dalil tentang shalat dari al-hadits ditegaskan bahwa shalat termasuk rukun Islam sebagaimana riwayat hadits dari Ibnu 'Umar ra. dari Rasulullah SAW, beliau bersabda:

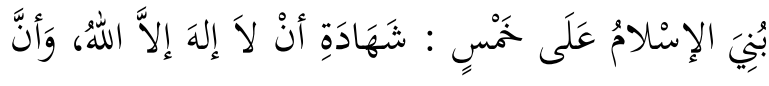

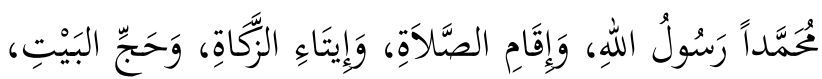

$$
\begin{aligned}
& \text { وَصَوْْم رَمَضَانَ }
\end{aligned}
$$

"Islam dibangun di atas lima perkara, yaitu syahadat laa ilaaha illallah dan Muhammadan Rasulullah, menegakkan shalat, menunaikan zakat, haji dan puasa Ramadhan." 45

Dalam riwayat hadits lain dari Mu'adz ra. saat diutus oleh Rasulullah SAW ke negeri Yaman untuk mendakwahkan Islam kepada ahlul kitab yang tinggal di negeri tersebut, Nabi SAW bersabda:

${ }^{45}$ HR. al-Bukhari: 8 dan HR. Muslim:113 


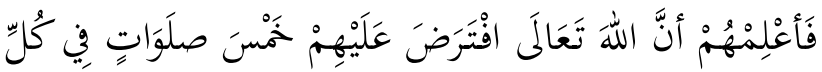

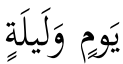

“Ajarkanlah kepada mereka bahwa Allah memfardhukan kepada mereka lima shalat dalam sehari semalam."

Selanjutnya kapan shalat mulai diwajibkan? Melihat sejarah para nabi dan rasul, sebelum Rasulullah SAW. juga disyariatkan shalat. Hal ini diceritakan al-Qur'an dalam berbagai ayatnya. ${ }^{47}$ Hal ini menunjukkan bahwa shalat juga diwajibkan kepada Nabi Musa dan umatnya (kaum Bani Israil), hanya saja sebagian kecil diantara kaum Bani Israil yang melaksanakan kewajiban shalat tersebut.

Selanjutya pada masa risalah Muhammad SAW, shalat juga tetap disyariatkan. Hak ini menunjukkan bahwa sebelum peristiwa Isra Mi'raj, Rasulullah dan para sahabat juga sudah melakukan shalat hanya saja tidak sama dengan

\footnotetext{
${ }^{46}$ HR. al-Bukhari:1395 dan HR. Muslim:121

${ }^{47}$ Lihat dalam QS. al-Baqarah [2]: 83.
} 
shalat yang lima waktu. Barulah pada peristiwa Isra Mi'raj, shalat lima waktu diwajibkan. Hal ini didasarkan pada riwayat dari Anas bin Malik ra., dia berkata:

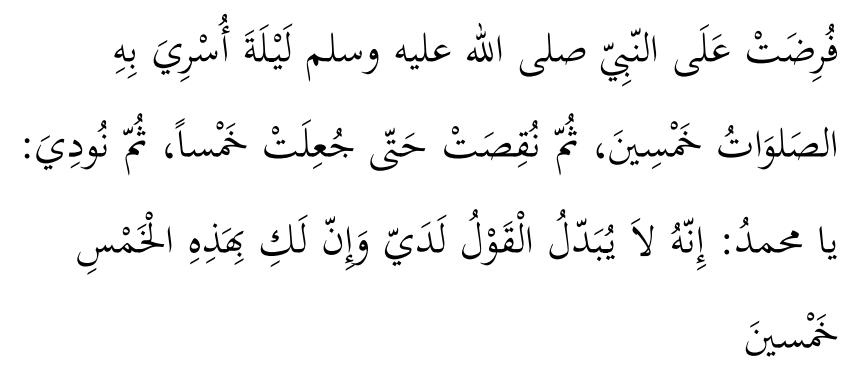

"Telah difardhukan kepada Nabi SAW. shalat pada malam beliau diisra'kan 50 shalat. Kemudian dikurangi hingga tinggal 5 shalat saja. Lalu diserukan, "Wahai Muhammad, perkataan itu tidak akan tergantikan. Dan dengan lima shalat ini sama bagimu dengan 50 kali shalat." 48

Riwayat hadits di atas, menunjukkan bahwa shalat lima waktu diwajibkan pada malam Isra Mi'raj. Tetapi kapankah Isra Mi'raj? Betulkah 27 Rajab tahun ke 5 sebelum hijriah? Wallahu

${ }^{48}$ HR. at-Tirmidzi No. 213, Derajat hadits: hasan shahih gharib. Dishahihkan oleh Syaikh Al Albani dalam Shahih wa Dhaif 
A'lam. Hal ini disebabkan tidak ada kesepakatan para ulama hadits dan para sejarawan muslim tentang kapan peristiwa ini terjadi, ada yang menyebutnya Rajab, dikatakan Rabiul Akhir, dan dikatakan pula Ramadhan atau Syawal. ${ }^{49}$

\section{Tujuan dan Fungsi Shalat}

Ibadah yang Allah perintahkan kepada hambahambaNya seperti shalat, puasa, zakat, haji dan lainnya dalam Islam memiliki tujuan tertentu (Maqasidussyariah). Berkaitan tentang disyariatkan ibadah shalat, dijelaskan dalam riwayat hadits berikut:

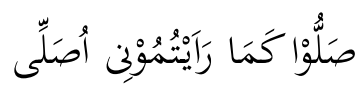

"Shalatlah kamu sekalian sebagaimana kamu melihatku mengerjakan shalat". 50

${ }^{49}$ Ibnu Hajar al-Asqalani, Fathul Bari, (Jakarta: Pustaka Imam Syafi'i, 2016), h. 242-243.

${ }^{50}$ HR. al-Bukhari 
Riwayat hadits ini secara tersurat, tidak dijelaskan secara rinci tentang tujuan didirikannya shalat, akan tetapi secara tersirat mengatakan bahwa siapapun yang menjalankan ibadah hendaknya memiliki kepribadian, perilaku dan akhlak seperti Nabi. Atau dengan kata lain, shalatnya mengikuti apa yang telah dituntunkan oleh Nabi SAW.

Selanjutnya pada sub bahasan ini diuraikan tentang tujuan dan fungsi shalat dalam kehidupan manusia sebagai berikut:

a. Tujuan Shalat

Beberapa ayat dalam al-Qur'an dan alHadits Nabi saw telah dijelaskan tentang tujuan didirikan shalat. Hal ini terdapat dalam alQur'an sebagai berikut:

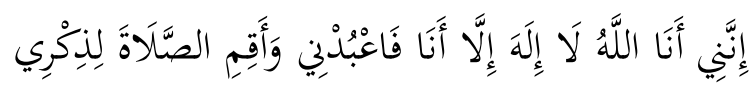

"Sesungguhnya aku ini adalah Allah, tidak ada Tuhan (yang hak) selain Aku, Maka 
sembahlah aku dan dirikanlah shalat untuk mengingat aku." 51

Ayat di atas, dapat dipahami bahwa tujuan ibadah shalat adalah untuk mengingat Allah SWT. Mengingat Allah artinya khusyu' serta menghadirkan hati dalam shalat. Hal ini ada beberapa dalil hadist perintah khusyu' dalam shalat sebagai berikut:

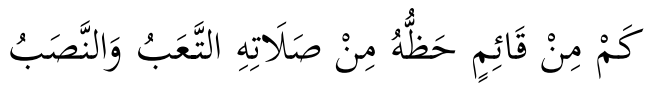

"Berapa banyak orang yang menegakkan shalat hanya memperoleh letih dan payah". ${ }^{52}$

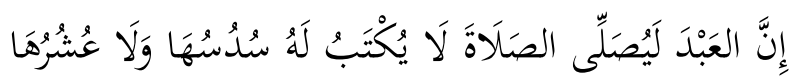

"Sesungguhnya seorang hamba menunaikan shalat tetapi tidak ditulis untuknya sperenamnya dan tidak pula sepersepuluhnya".

${ }^{51}$ QS. Thahaa [20]:14.

${ }^{52}$ HR. Nasa'i

${ }^{53}$ HR. Abu Dawud, Nasa'i, Ibnu Hibban dari Ammar Bin Yasir 
Tujuan shalat kedua adalah sebagai pencegah tindakan keji dan mungkar. Hal ini sesuai dengan firman Allah dalam al-Qur'an surat al-'Ankabut di bawah ini bahwa fungsi dan peranan shalat adalah sebagai pencegah tindakan keji dan mungkar. ${ }^{54}$

\section{b. Fungsi Shalat}

Seluruh perintah Allah swt. tidak mungkin menyusahkan manusia, termasuk juga perintah shalat bagi manusia. Allah membuat perintah kepada manusia justru untuk memberikan jalan kemudahan kepada manusia agar selamat di dunia maupun di akhirat. ${ }^{55}$ Selanjutanya terkait fungsi shalat bagi kehidupan manusia diuraikan sebagai berikut:

1) Melalui shalat, Allah akan menghapus dosadosa hambaNya. ${ }^{56}$

2) Melalui shalat, Allah akan memberikan rahmat, petunjuk, dan keberuntungan. ${ }^{57}$

${ }^{54}$ QS. al-'Ankabuut [29]:45 dan lihat keterangan selanjutanya pada QS Ali Imran: 134-136, QS Al Maidah: 90: 90-91, QS An Nur: 21, 22, dan QS Asy Syura: 36-38.

${ }^{55}$ QS. Thahaa [20]: 2.

${ }^{56}$ QS. Huud [11]: 114. 
3) Melalui shalat, Allah SWT memberikan ridha-Nya dan Allah memberikan kesudahan yang baik. ${ }^{58}$

4) Melalui shalat, Allah menghilangkan rasa khawatir dan sedih pada hamba-Nya. ${ }^{59}$

5) Melalui shalat, Allah akan memberi ampunan, rezeki, dan ketinggian derajat. ${ }^{60}$

6) Melalui shalat, Allah mencegah manusia dari sifat keluh kesah dan kikir. ${ }^{61}$

\section{Akhlaq dalam Shalat}

Akhlaq dalam shalat yang dimaksudkan pada bahasan ini adalah seseorang dalam melaksanakan ibadah shalat dengan berusaha menghindarkan diri dari bid'ah (penyimpangan), dan menyesuaikannya dengan tuntunan shalat Nabi Muhammad saw berdasarkan hadits-hadits maqbullah. Berikut ini tuntunan shalat Nabi Muhammad SAW berdasarkan dalil-dalil maqbullah:

\footnotetext{
${ }^{57}$ QS. an-Nuur [24]: 56

${ }^{58}$ QS. ar-Ra'du [13]: 22.

${ }^{59}$ QS. al-Baqarah [2]: 277

${ }^{60}$ QS. al-'Anfaal [8]: 3-4.

${ }^{61}$ QS. a1-Ma'arij [70]: 19-23
} 
a. Niat di dalam hati secara ikhlas karena Allah semata. $^{62}$

b. Berdiri sempurna menghadap kea rah qiblat bagi yang mampu berdiri.

c. Bertakbir dengan mengucapkan اللّ أكبر, dengan cara:

1) Mengangkat kedua tangan sejajar dengan kedua telinga dan atau kedua bahunya, sambil bertakbir.

2) Meletakkan tangan kanan di atas punggung pergelangan dan lengan kiri, dan mengecangkan keduanya di atas dada.

3) Pandangan kea rah tempat sujud, tidak boleh menutup mata, tidak boleh menengadah ke atas, dan tidak memalingkan pandangan ke kanan-kiri

4) Kemudian membaca salah satu do'a iftitah

d. Membaca surat al-Fatihah secara tartil (jelas dan perlahan) dengan sebelumnya bermohon perlindungan dengan membaca ta'awudz tanpa dikeraskan, lalu membaca basmalah.

${ }^{62}$ QS. Al-Bayyinah [98]: 5. 
e. Ruku'. Angkat kedua tangan seperti takbiratul ihram sambil bertakbir. الله أكبر menuju ke posisi ruku'. Ketika sedang ruku' dituntunkan membaca do'a:

سبحانك اللهم ربّنا وبحمدك اللهم اغفرلى (Maha suci Engkau ya Allah: Tuhan kami dan dengan memuji Engkau ya Allah ampunilah hamba) atau سبحان ربّي العظيم (Maha suci Tuhanku yang Maha Agung).

f. I'tidal setelah ruku', yakni berdiri tegak (i'tidal) dengan sempurna dan tenang (thuma'ninah). Saat i'tidal, dituntunkan untuk mengucapkan: sambil mengangkat kedua tangan daينا ولك : الحمد.

g. Sujud. Bertakbirlah tanpa mengangkat tangan menuju gerakan sujud dengan meletakkan kedua lutut lebih dahulu lalu kedua tangan, kemudian letakkan wajah (dahi dan hidung). Ketika sedang sujud dituntunkan membaca do'a: سبحانك (Maha suci Engkau ya Allah: Tuhan kami dan dengan memuji 
Engkau ya Allah ampunilah hamba) atau سبحان Maha suci Tuhanku yang Maha Tinggi). Saat sujud hendaklah meletakkan kedua telapak tangan sejajar dengan kedua telinganya dan wajahnya diletakkan di antara kedua telapak tangannya, kedua telapak kaki ditegakkan, dimana jari-jemarinya dirapatkan dan dihadapkan ke arah qiblat.

h. Duduk iftirasy. Bangkit dari sujud sambil bertakbir menuju posisi duduk, dimana posisi tangan kanan berada di atas paha-lutut kanan dan tangan kiri di atas paha-lutut kiri dan dilarang duduk dengan bertumpu pada tangan. Saat duduk iftirasy,berdoa'lah:

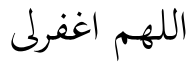

$$
\text { (Ya Allah, }
$$

ampunilah kami, kasihilah kami, cukupilah kami, tunjukkilah kami dan berikan rizki kepada kami) atau membaca : ربّ اغفرلي، ربّ اغفرلي (Ya Allah ampunilah aku, ya Allah ampunilah aku). Setelah itu sujudlah untuk kedua kalinya 
dengan bertakbir dan membaca do'a sujud seperti sebelumnya.

Ketika bangkit dari sujud kedua pada rakaat ganjil dan akan berdiri pada rakaat genap, disunnahkan untuk duduk istirahat sejenak. Kemudian baru berdiri dengan menekankan kedua telapak tangan di tanah lalu melatakkan keduanya pada kedua paha untuk berdiri dan langsung bersedekap, tanpa mengangkat tangan. Selanjutnya, kerjakanlah rakaat kedua ini, seperti rakaat yang pertama, hanya saja tidak membaca do'a iftitah.

i. Duduk tasyahhud

Duduk Tasyahhud awal

Posisi duduk tasyahhud awal, posisinya duduknya iftirasy, yakni duduk di atas bentangan kaki kiri dengan menjadikan kaki kiri sebagai firasy (alas), sementara telapak kaki kanan ditegakkan dengan jari-jari kaki kanan menghadap qiblat. Posisi tangan kirinya di atas lutut kirinya dan meletakkan tangan kanannya diatas lutut kanannya, dan beliau lingkarkan jarinya sehingga membentuk angka lima puluh 
tiga, lalu beliau memberi isyarat dengan jari telunjuk. $^{63}$

Adapun bacaan tahiyyat atau tasyahhud awal:

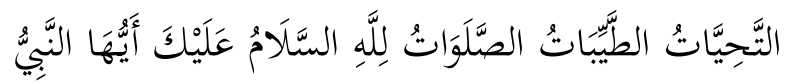

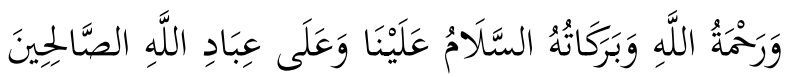

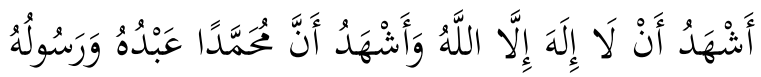

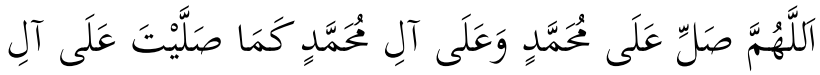

إِبْرَاهِيمَ وَبَارِكْ عَلَى عُحَمَّدِ وَعَلَى آلِل عُمَسَّدِ كَمَا بَارَكْتَ عَلَى

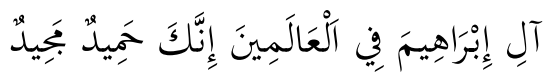

"Segala penghormatan bagi Allah, shalawat dan juga kebaikan. Semoga keselamatan terlimpahkan kepadamu wahai Nabi dan juga rahmat dan berkahnya. Semoga keselamatan terlimpahkan atas kami dan hamba Allah yang shalih. Saya bersaksi bahwa tidak ada tuhan yang berhak disembah selain Allah, dan saya

${ }^{63}$ HR. Muslim: 912 
bersaksi bahwa Muhammad adalah hamba dan utusan Allah ${ }^{64}$

Ya Allah limpahkanlah rahmat atas Muhammad dan keluarganya sebagaimana telah Engkau limpahkan rahmat atas Ibrahim. Berkatilah Muhammad dan keluarganya sebagaimana Engkau telah memberkati Ibrahim. Di seluruh alam ini Engkau Maha Terpuji dan Maha Agung) kemudian salam sebagaimana yang telah kamu ketahui."

\section{Duduk Tasyahhud akhir}

Posisi duduk tasyahhud akhir posisi duduknya tawarruk, yakni pangkal paha atas (pantat) yang kiri duduk bertumpu pada lantai. Sedangkan posisi kaki kanan sama dengan tahiyat awal.

Bacaan pada tasyahhud akhir sama dengan tasyahhud awal, hanya ditambah dengan do'a berikut:

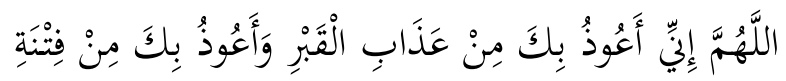

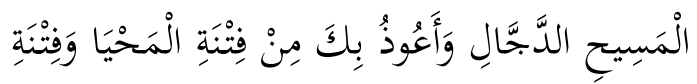

${ }^{64}$ HR. Muslim: 612. 


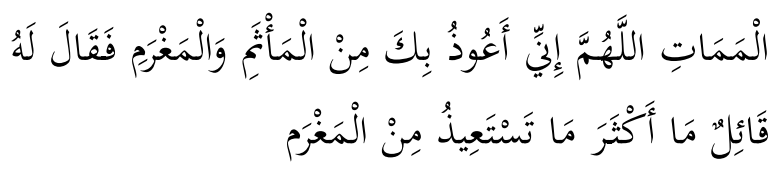

"Ya Allah, aku berlindung kepada-Mu dari siksa kubur dan aku berlindung kepada-Mu dari fitnah al-Masihid Dajjal, dan aku berlindung kepada$\mathrm{Mu}$ dari fitnah kehidupan dan fitnah kematian. Ya Allah, aku berlindung kepada-Mu dari perbuatan dosa dan hutang". ${ }^{65}$

Atau

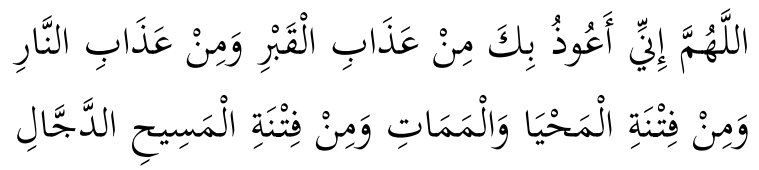

"Ya Allah aku berlindung kepadaMu dari suksa kubur dan dari siksa api neraka dan dari fitnah kehidupan dan kematian dan dari fitnah alMasihid Dajjal."66

j. Salam

Memalingkan kepala ke arah kanan dan kearah kiri , sehingga pipi dapat dilihat dari arah belakang. Bacaan salam:

${ }^{65}$ HR. al-Bukhari: 789.

${ }^{66}$ HR. al-Bukhari: 1288. 


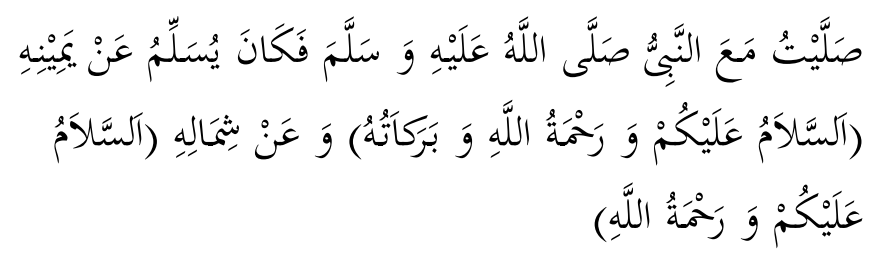

"Saya melaksanakan shalat bersama Nabi saw. Beliau mengucapkan salam kearah kanan dengan bacaan lafaz "Assalamu'alaikum Warahmatullahi Wa Barokatuh". Dan kearah kiri dengan lafaz "Assalamu 'Alaikum Warahmatullah".

\section{Ancaman bagi yang Meninggalkan Shalat}

Bagi seorang muslim yang sudah terkena kewajiban shalat karena sudah baligh dan berakal, kemudian meninggalkan shalat dengan sengaja, dihukumi syirik dan kufur. Hal ini sebagaimana sabda Nabi Saw.:

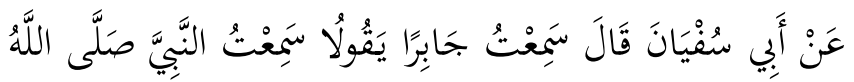

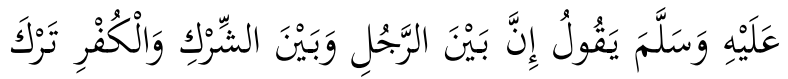

$$
\begin{aligned}
& \text { الصَّكَةِة }
\end{aligned}
$$

"Dari Abu Sufyan dia berkata, saya mendengar Jabir berkata, "Saya mendengar Nabi shallallahu 'alaihi wasallam bersabda: "Sungguh, yang

${ }^{67}$ HR. Abu Daud dan Ibnu Khuzaimah. 
memisahkan antara seorang laki-laki dengan kesyirikan dan kekufuan adalah meninggalkan shalat'." ${ }^{68}$

\section{عَنْ عَبْدِ اللَّهِهْنِ بُرَيْدَةَ عَنْ أَبِيهِه قَالَ قَالَ رَسُولُ اللَّهِ صَلَّى اللَّهُ

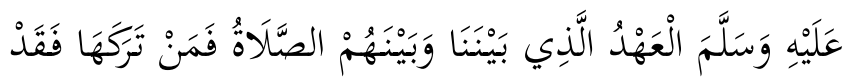

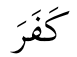

"Dari Abdullah bin Buraidah dari bapaknya dia berkata, Rasulullah shallallahu 'alaihi wasallam bersabda: "Perjanjian antara kami dan mereka adalah shalat, maka barangsiapa yang meninggalkannya maka dia sungguh telah kafir'."69

Beberapa ancaman hukuman bagi yang meremehkan dan meninggalkan shalat fardlu 5 waktu sebagaimana dijelaskan berikut ini:

a. Mendapatkan siksaan yang sangat amat dahsyat di alam kubur sampai datangnya hari kiamat. Gambaran siksaan yang diterima bagi orang yang meninggal shalat, yaitu kepalanya

${ }^{68}$ HR. Muslim nomor: 116.

${ }^{69}$ HR. Tirmidzi: 2545. 
dilempari batu dalam keadaan rebahan terlentang hingga kepalanya hancur. 70 na'udzubillah.

b. Mendapatkan siksa "al-Wail" di akhirat. ${ }^{71}$

c. Mendapatkan kehinaan dan tidak mampu sujud di akhirat, ketika seluruh kaum beriman sujud. ${ }^{72}$ Hal ini juga dikuatkan oleh riwayat hadits berikut:

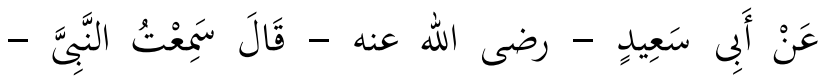

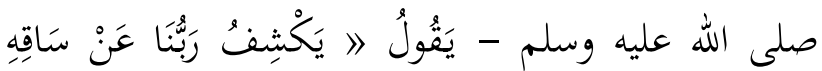

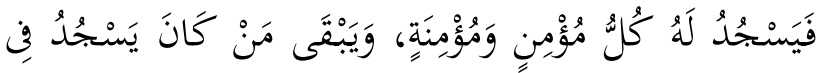

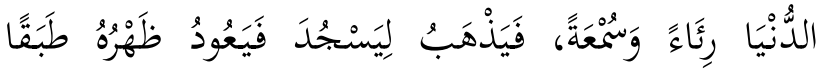

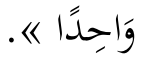

"Abu Sa'id al-Khudry ra. berkata: "Aku pernah mendengar Nabi Muhammad SAW. bersabda: "Rabb kita menyingkapkan betis-Nya, maka sujud kepada-Nya setiap lelaki dan wanita beriman, sedangkan yang di dunianya sujud

\footnotetext{
${ }^{70} \mathrm{HR}$. al-Bukhari.

${ }^{71}$ QS. al-Ma'uun [107]: 4-5.

${ }^{72}$ QS. al-Qalam [68]: 42-43.
} 
karena riya' dan sum'ah ketika ia ingin sujud maka kembali punggungnya satu bagian". 73
d. Merasakan siksa di neraka Saqar. ${ }^{74}$
e. Mendapatkan siksa berupa "غَيْيُ"75 (keburukan) di akhirat. ${ }^{76}$

\section{Makna Spiritual Shalat}

Makna spiritual shalat adalah upaya menggali nilai-nilai atau makna di balik ibadah shalat the spirit of shalat), baik gerakan dan bacaan shalat untuk meraih keberhasilan hidup manusia. Oleh karena, cakupannya sangat luas dan perlu pembahasan lebih rinci, maka pada sub bahasan ini hanya difokuskan pada makna spiritual gerakan shalat sementara makna spiritual bacaan shalat diselipkan dalam setiap bahasan.

${ }^{73}$ HR. al-Bukhari.

${ }^{74}$ QS. al-Muddatsir [74]: 26-30 dan 38-44.

75 Ibnu Abbas ra. berkata: "Ghayy adalah kerugian”. Qatadah ra. berkata: "Ghayy adalah keburukan". Abdullah bin Mas'ud ra. berkata: "Ghayy adalah lembah di dalam neraka Jahannam sangat dalam dan baunya sangat busuk."

${ }^{76}$ QS. Maryam [19]: 59. 
a. Gerakan Takbiratul Ihram

Pengawalan segala sesuatu, sebagaimana hidup dimulai kelahiran, sesuatu yang ada pasti ada awalnya. Keimanan tersebut, mengantarkan pada keyakinan bahwa semuanya berawal dari Allah. Oleh karenanya, dengan membaca takbir sebagai tanda dimulainya ibadah shalat, berarti mengembalikan kepada segala aktivitas adalah karena Allah. Takbiratul Ihram sebagai starting point shalat, simbol starting perjalan hidup. Maknanya spiritualnya adalah penyerahan totalitas pada yang Maha Awal bahwa karena-Nya ada dan karena-Nya melakukan perjalanan hidup. Selain itu, takbir juga berarti pengungkapan bahwa hanya Allah SWT yang patut disembah. ${ }^{77}$

b. Gerakan Berdiri

Posisi berdiri saat shalat dalam kondisi norman, disyariatkan badan berdiri tegak, posisi pandangan menunduk ke arah tempat sujud, dan kedua tangan di atas dada (memegang ulu hati).

${ }^{77}$ Ibnu Qayyim al-Jauziyyah, Rahasia dan Hikmah Di Balik Ibadah Shalat, Terj. Ahmad Sarifuddin, (Solo: Ziyad Visi Media, 2008), h. 59. 
Makna spiritual masing-masing gerakan dalam posisi berdiri dijelaskan sendiri-sendiri, sebagai berikut:

1) Makna spiritual gerakan shalat dengan posisi berdiri tegak melambangkan bahwa manusia selalu siap berjalan menjelajahi kehidupan. Sedangkan tegak memiliki makna bahwa kehidupan harus ditegakkan (ditumbuhkan) pada ruang waktu, iman harus ditegakkan, akhlak harus ditegakkan, amalan pribadi dan amalan sosial harus ditegakkan. Dengan demikian, agama didirikan atau ditegakkan dengan menegakkan ibadah shalat sebagaimana disebutkan dalam hadits bahwa shalat adalah tiang agama. ${ }^{78}$

2) Makna spiritual posisi kepala menunduk ke arah tempat sujud memberikan pelajaran bahwa dalam perjalanan hidup akan tunduk dan patuh pada segala hukum dan kehendak Allah bebas dari rasa kesombongan diri.

${ }^{78}$ HR. at-Timirdzi: 2541. 
3) Kedua tangan memegang ulu hati, simbol bahwa hati akan selalu dijaga kebersihannya dalam perjalanan hidup. Ini merupakan simbol kewaspadaan yang wajib dimiliki oleh setiap manusia untuk melihat sesuatu secara sadar dan dengan pertimbangan yang jauh dari untung dan rugi. Agama mensyariatkan pada saat awal berdiri shalat agar membaca iftitah, ta'awudz sebelum membaca surah al-Fatihah dan dilanjutkan dengan membaca surah-surah lain dalam al-Qur'an. Membaca iftitah berarti manusia menghindarkan diri dari penyakit alghaflah (kelalain kepada Allah SWT), yang menjadi penghalang antara manusia dengan Allah. 79 Oleh karena itu, Allah memerintahkan manusia untuk membaca ta'awudz sebagai bentuk penyerahan diri kepada Allah dan meminta perlindungannya. ${ }^{80}$ Selain itu, juga untuk menghidupkan hati agar apa yang dibaca dari

${ }^{79}$ Ibnu Qayyim al-Jauziyyah. Ibid., 60.

80 Ibid., 62. 
ayat-ayat al-Qur'an menjadi cahaya (nuur) berupa hidayah dari Allah dalam melihat banyaknya permasalahan yang dihadapinya. ${ }^{81}$

\section{c. Gerakan Ruku'}

Bacaan ruku' dalam shalat disyariatkan membaca سبحانك اللهم ربّناوبحمدك اللهم اغفرلى atau sebagai ungkapan rasa tunduk manusia kepada yang disembahnya, karena kebesaran, keagungan, dan kemulianNya. ${ }^{82}$ Allah menyariatkan agar seorang hamba mengangkat tangan sebelum dan sesudah ruku' sebagai bentuk pengagungan terhadap Allah dalam bentuk ubudiyah, di samping sebagai ittiba' (mengikuti) Rasulullah SAW. ${ }^{83}$ Dengan demikian, ruku' adalah sebuah ajaran kembali kepada Sang Pencipta. Segala sesuatu tidak pernah kita miliki secara pribadi. Semua yang datang dari Sang Pencipta akan kembali kepada Sang Pencipta. Semua yang "dimiliki" manusia hanyalah ujian. Itu tandanya bahwa Sang

\footnotetext{
${ }^{81}$ Ibid., 75.

82 Ibid., 78.

${ }^{83}$ Ibid., 79
} 
Penciptalah yang menjadi dasar acuan hidup manusia dan benar-benar manusia mengembalikan urusan akhirnya kepada Sang Pencipta, yaitu hanya Allah SWT.

\section{d. Gerakan I'tidal}

Gerakan I'tidal memberikan pelajaran yang sangat berharga untuk mengisi perjalanan hidup dengan penuh puja dan puji pada Allah serta penuh syukur setiap saat sehingga tercipta kepatuhan dan ketaatan. Oleh karenanya, I'tidal adalah rukun khusus yang ditujukan untuk hati, sebagaimana rukun lain seperti ruku' dan sujud. Semakin besar manusia mengetahui hasil ciptaan Allah, maka akan tumbuh kekaguman dan kecintaan pada Allah sehingga tumbuh rasa cinta dan ikhlas menjalani hidup sesuai Kehendak Allah. Hal ini memberikan makna, bahwa melalui disyariatkan I'tidal dalam shalat manusia berkomitmen tidak akan melenceng dari jalan Sang Pencipta (Allah SWT) dan tidak akan berpindah kepada jalan atau ajaran yang lain dalam menjalankan hidupnya di dunia ini. 


\section{e. Gerakan Sujud}

Makna spiritual gerakan sujud dalam shalat adalah hati, fikiran, dan anggota tubuh manusia direndahkan serendahnya untuk menyembah Allah SWT dalam satu irama dan juga sebagai tanda ketundukan total pada segala kehendak Allah dan mengikuti segala kehendak Allah. Menyatukan kehendak Allah dengan Kehendak kita. Hal ini dikarenakan bahwa sujud adalah penyerahan total kepada Sang Pencipta tanpa syarat. Sujud adalah symbol kepasrahan yang sangat total. Oleh karenanya, tidak ada lagi ketakutan, tidak ada lagi kekhawatiran, tidak ada lagi tawar menawar dalam memasrahkan diri kepada Sang Pencipta. Sang Pencipta selalu memberikan yang terbaik untuk makhluknya, yang belum tentu sesuai dengan apa yang mereka mau. Sujud bersikap dengan menaruh kepala kita serendah mungkin di hadapan Sang Pencipta. ${ }^{84}$ Sedangkan sujud dilakukan 2 kali dimaknai bahwa sujud pertama merupakan penyatuan Kehendak Allah dengan Kehendak

${ }^{84}$ Ibid., 80-81. 
ruhani/hati/jiwa yang diselangi dengan permohonan pada duduk antara 2 sujud. Sujud kedua sebagai pernyataan pengagungan kepada Dzat Nya Allah personal antara makhluk dan Sang Pencipta, pernyataan ingin kembali pada Sang Pencipta akhir dari perjalanan.

f. Gerakan Duduk di antara dua Sujud

Posisi duduk di atas kedua lutut saat melakukan duduk diantara dua sujud, mengambarkan seorang hamba yang bersimpuh ta'dzim di hadapan Allah, menyerahkan diri sepenuhnya, meminta ampunan dengan sepenuh jiwa dan hati terhadap apa yag telah dilakukannya, menginginkan agar Allah memberikan ampunan dan memaafkannya, serta manusia menyatakan bahwa akan menjadikan hawa nafsu sebagai musuh. ${ }^{85}$ Hal ini memberikan pelajaran bahwa, pengungkapan manusia tersebut untuk memberikan segala kebutuhan yang diperlukan dalam bekal perjalanan menuju pertemuan dengan Allah,

${ }^{85}$ Ibid., 83-84 
butuh sumber dukungan hidup jasmani dan ruhani, serta pemeliharaan dan perlindungan jasmani ruhani agar tetap pada jalan Allah. Dengan demikan, duduk antara 2 sujud merupakan sikap di mana manusia akan dihadapkan pada suatu keadaan bersimpuh di hadapan Sang Pencipta, yakni Allah SWT. Sujud diantara dua sujud menjadi simbol dimana manusia akan dimintai pertanggung jawaban kepada Sang Maha Kuasa dan dihadapkan kepada pengadilan yang seadil-adilnya. Tidak ada hakim yang Maha Adil selain Sang Pencipta, yakni hanya Allah SWT semata-mata.

g. Gerakan Attahiyat

Kata "at-Tahiyah" berasal dari kalimat "الحية“" (kehidupan). Oleh karena itu, seorang yang membaca attahiyatulillah, memiliki arti permintaan kepada Allah SWT agar terus diberikan umur yang panjang. Kemudian dilanjutkan dengan membaca shalawat yang menggunakan lafal jamak dan memakai alif dan lam. Hal ini dimaksud agar, ketika disebutkan 
lafal "shalat", baik secara khusus maupun umum, maka semuanya itu hanya ditujukan untuk Allah SWT. ${ }^{86}$

Gerakan attahiyat juga menggambarkan tahap pemantapan. Hal dikarenakan perjalanan hidup manusia, kadang mengalami naik dan turun, manusia tidak lepas dari sifat lupa. Oleh karena itu, memerlukan pemantapan yang direfresh dan diulang untuk semakin kokoh dalam bentuk Ikrar Syahadat, dengan simbol pengokohan ikrar melalui telunjuk kanan.

Dengan demikian, attahiyat merupakan sikap menerima dari semua keputusan Sang Pencipta tanpa protes. Jadi, semua keputusan akhir, apapun yang kita lakukan kembali lagi kepada Sang Pencipta, baik di dunia maupun setelah meninggalkan dunia. Sebelum Ikrar memberikan penghormatan untuk para Utusan Allah yang melalui merekalah manusia mengenal Allah juga melalui ajaranNya, manusia dibimbing menujuNya dan menjadikan

${ }^{86}$ Ibid., 90-91. 
mereka menjadi saksi atas Ikranya. Sedangkan shalawat menjadi pernyataan kebersediaan mengikuti apa yang diajarkan Rasulullah Muhammad SAW, dan menempatkannya sebagai pimpinan dalam perjalanan kita. Salam penghormatan kepada Bapak para Nabi Nabi Ibrahim yang menjadi bapak induk ajaran Tauhid. Kemudian diakhir dengan permohonan doa dan permohonan perlindungan dari kejahatan tipuan Dajal / Iblis untuk menjaga perjalanan tetap pada keselamatan dan berhasil mencapai Allah.

\section{h. Gerakan Salam}

Salam adalah penutup sekaligus awal dari mulainya praktek aplikasi shalat. Salam merupakan simbol dari putaran yang dimulai dari kanan ke kiri dengan poros badan yang menunjukkan bahwa hidup ini tidak sendiri, sehingga hendaknya menyebarkan salam dan berkah kepada sesama untuk saling bahu membahu menegakkan kehidupan yang 
harmonis (selaras) dan tegaknya kedamaian, kesejahteraan dan keselamatan di bumi Allah.

\section{Rangkuman}

1. Pengertian shalat secara bahasa berarti do'a (permohonan) atau rahmat. Secara terminologis memiliki pengertian ibadah yang mengandung di dalamnya ucapan dan perbuatan tertentu yang dimulai dengan takbir dan ditutup dengan salam. Ibadah shalat dalam Islam mempunyai kedudukan yang sangat penting, antara lain: ibadah pertama kali diwajibkan oleh Allah SWT yang perintahnya langsung diterima Rasulullah SAW, shalat sebagai tiang agama, dan amalan yang pertama kali dihisab pada hari kiamat.

2. Beberapa dalil al-Qur'an dan al-Hadits yang menunjukkan kewajiban shalat fardhu 5 (lima) waktu, antara lain: QS. an-Nisaa' [4]:103, QS. al-Baqarah [2]: 3, QS. Thahaa [20]: 14, HR. al-Bukhari: 8 dan 1395, serta HR. Muslim:113 dan 121.

3. Tujuan ibadah shalat adalah untuk mengingat Allah SWT dan pencegah tindakan keji dan mungkar. Adapun fungsi shalat, antara lain: sebagai penghapus dosa, sebagai sebab Allah memberikan rahmat, 
petunjuk, keberuntungan, ridha-Nya dan Allah memberikan kesudahan yang baik, Allah menghilangkan rasa khawatir dan sedih, Allah akan memberi ampunan, rezeki, dan ketinggian derajat, dan Allah mencegah manusia dari sifat keluh kesah dan kikir.

4. Akhlaq dalam shalat yang dimaksudkan adalah seseorang dalam melaksanakan ibadah shalat dengan menghindarkan diri dari bid'ah (penyimpangan), dan menyesuaikannya dengan tuntunan shalat Nabi Muhammad saw berdasarkan hadits-hadits maqbullah.

5. Ancaman bagi seorang muslim yang sudah terkena kewajiban shalat karena sudah baligh dan berakal, kemudian meninggalkan shalat dengan sengaja, dihukumi syirik dan kufur, di samping beberapa ancaman lainnya, yaitu: (1) mendapatkan siksaan yang sangat amat dahsyat di alam kubur sampai datangnya hari kiamat; (2) mendapatkan siksa "al-Wail" di akhirat; (3) mendapatkan kehinaan dan tidak mampu sujud di akhirat, ketika seluruh kaum beriman sujud; (4) merasakan siksa di neraka Saqar; dan (5) Mendapatkan siksa berupa “" "غَيْ di akhirat. 
6. Makna spiritual shalat adalah upaya menggali nilainilai atau makna di balik ibadah shalat (the spirit of shalat), baik gerakan dan bacaan shalat untuk meraih keberhasilan hidup manusia.

a. Takbiratul Ihram memberikan pelajaran tentang penyerahan totalitas pada yang Maha Awal bahwa karena-Nya ada dan karena-Nya melakukan perjalanan hidup. Selain itu, takbir juga berarti pengungkapan bahwa hanya Allah SWT yang patut disembah.

b. Makna spiritual gerakan shalat dengan posisi berdiri tegak melambangkan bahwa manusia selalu siap berjalan menjelajahi kehidupan. Sedangkan tegak memiliki makna bahwa kehidupan harus ditegakkan (ditumbuhkan) pada ruang waktu, iman harus ditegakkan, akhlak harus ditegakkan, amalan pribadi dan amalan sosial harus ditegakkan. posisi kepala menunduk ke arah tempat sujud memberikan pelajaran bahwa dalam perjalanan hidup akan tunduk dan patuh pada segala hukum dan kehendak Allah bebas dari rasa kesombongan diri. Kedua tangan memegang ulu hati, simbol bahwa hati akan selalu dijaga kebersihannya dalam 
perjalanan hidup. Ini merupakan simbol kewaspadaan.

c. Ruku' adalah sebuah ajaran kembali kepada Sang Pencipta. Segala sesuatu tidak pernah kita miliki secara pribadi. Semua yang datang dari Sang Pencipta akan kembali kepada Sang Pencipta. Semua yang "dimiliki" manusia hanyalah ujian.

d. Gerakan I'tidal memberikan pelajaran yang sangat berharga untuk mengisi perjalanan hidup dengan penuh puja dan puji pada Allah serta penuh syukur setiap saat sehingga tercipta kepatuhan dan ketaatan. Dan juga melalui disyariatkan I'tidal dalam shalat manusia berkomitmen tidak akan melenceng dari jalan Sang Pencipta (Allah SWT) dan tidak akan berpindah kepada jalan atau ajaran yang lain dalam menjalankan hidupnya di dunia ini.

e. Sujud adalah penyerahan total kepada Sang Pencipta tanpa syarat dan simbol kepasrahan yang sangat total.

f. Posisi duduk di atas kedua lutut saat melakukan duduk diantara dua sujud, mengambarkan seorang hamba yang bersimpuh ta'dzim di hadapan Allah, menyerahkan diri sepenuhnya, meminta ampunan 
dengan sepenuh jiwa dan hati terhadap apa yag telah dilakukannya, menginginkan agar Allah memberikan ampunan dan memaafkannya, serta manusia menyatakan bahwa akan menjadikan hawa nafsu sebagai musuh.

g. Attahiyat sebagau tahap pemantapan yang ditunjukkan dengan sikap menerima dari semua keputusan Sang Pencipta tanpa protes.

h. Salam adalah penutup sekaligus awal dari mulainya praktek aplikasi shalat. Salam merupakan simbol dari putaran yang dimulai dari kanan ke kiri dengan poros badan yang menunjukkan bahwa hidup ini tidak sendiri, sehingga hendaknya menyebarkan salam dan berkah kepada sesama untuk saling bahu membahu menegakkan kehidupan yang harmonis (selaras) dan tegaknya kedamaian, kesejahteraan dan keselamatan di bumi Allah.

\section{Latihan/Tugas/Eksperimen}

Memperagakan atau mendemonstrasikan tata cara shalat sesuai tuntunan Rasulullah SAW berdasarkan dalil-dalil maqbullah dan mendiskusikan spirit shalat (bacaan dan gerakannya) dalam menjalani kehidupan. 


\section{DAFTAR PUSTAKA}

al-Asqalani, Ibnu Hajar, Fathul Bari, Jakarta: Pustaka Imam Syafi'i, 2016.

al-Jauziyyah, Ibnu Qayyim, Rahasia dan Hikmah Di Balik

Ibadah Shalat, Terj. Ahmad Sarifuddin, Solo: Ziyad Visi Media, 2008.

Compact Disc (CD) Ensiklopedi Hadits 9 Imam.

Departemen Agama RI, Al-Qur'an dan Tafsirnya, Jakarta: Departemen Agama RI, 2010.

Sabiq, Sayyid, Fiqih Sunnah, jilid 1, Jakarta, Pena Pundi Aksara, 2006. 


\section{BAB III \\ PUASA DAN KORELASINYA DALAM \\ PEMBENTUKAN \\ INSAN BERKARAKTER}

\section{A. Pendahuluan}

Puasa sebagai salah satu rukun Islam menempati posisi strategis dalam pembentukan insan berkarakter muttaqin sebagai perwujudan keimanan seorang mukmin. Hal ini dapat dipahami dari makna puasa (shiyam) merupakan kemampuan seseorang mukmin dalam menunda kesenangan sesaat berkaitan dengan "pengendalian diri" atau "sabar". Itulah الصَّوُْمُ نِصْفُ

الصَّبْر (puasa adalah setengah kesabaran). ${ }^{87}$ Di samping itu,

shiyam juga merupakan salah satu ibadah yang sangat istimewa kedudukannya di sisi Allah, ini sesuai dengan hadist berikut:

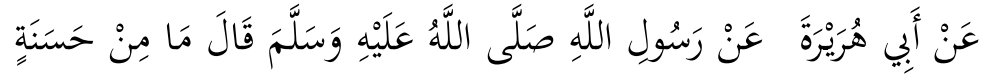

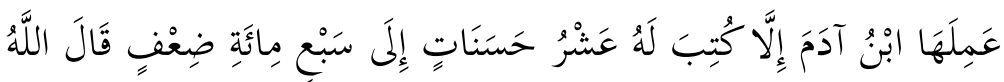

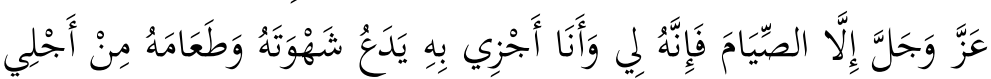

${ }^{87}$ HR. at-Tirmidzi: 3441. 
"dari Abu Hurairah dari Rasulullah SAW. beliau bersabda: "Tidak ada kebaikan yang dikerjakan anak Adam kecuali akan ditulis untuknya sepuluh kebaikan hingga 700 kali lipat. Allah -Azza wa Jalla- berfirman: 'Kecuali puasa, maka sesungguhnya puasa itu untuk-Ku dan Aku akan membalasnya, ia meninggalkan syahwat dan makanannya hanya karena Aku". ${ }^{88}$

Oleh karena itu, capaian pembelajaran pada bab tiga ini diharapkan mahasiswa dapat memahami: (1) hakikat puasa; (2) kewajiban puasa; (3) tujuan dan fungsi puasa; (4) hikmah puasa; (5) pengaruh puasa dalam pembentukan insan karakter; dan (6) makna spiritual puasa dalam kehidupan manusia. Paparan keenam bahasan tersebut, akan dibahas secara rinci pada penyajian materi di bawah ini.

\section{B. Penyajian Materi}

Berdasarkan uraian pada pendahuluan bahasan bab tiga ini, penyajian materi disesuaikan urutan bahasan dengan diawali tentang hakikat puasa, kewajiban puasa, tujuan dan fungsi puasa, hikmah puasa, pengaruh puasa dalam pembentukan insan karakter, serta diakhiri bahasan tentang makna spiritual puasa dalam kehidupan manusia.

${ }^{88}$ HR. an-Nasai: 2185. 


\section{Hakikat Puasa}

Puasa (shiyam), secara etimologi berarti أمساك (menahan diri dari sesuatu dan meninggalkan sesuatu). Hal ini sebagaimana disebutkan dalam firman Allah:

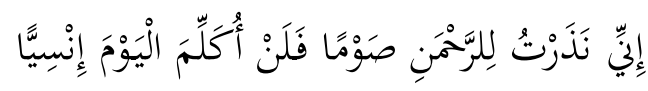

"Sesungguhnya aku telah bernadzar shaum untuk arRahman, maka aku tidak akan berbicara dengan seorang manusiapun pada hari ini". 89

Puasa secara terminologi dijelaskan sebagai berikut:

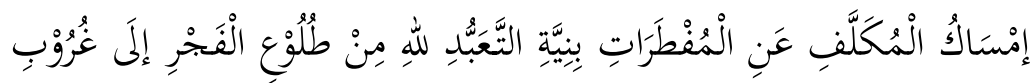

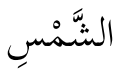

"Menahan diri dari makan, minum, hubungan biologis dan segala yang membatalkan selama sehari penuh, yakni sejak terbit fajar sampai terbenam matahari, dengan niat ta'abbudi (menjalankan perintah Allah dan mendekatkan diri kepadaNya)".90

${ }^{89}$ QS. Maryam [19]: 26.

${ }^{90}$ Qurthubi:130-131 
Pengertian puasa tersebut di atas, sesuai dengan firman Allah berikut:

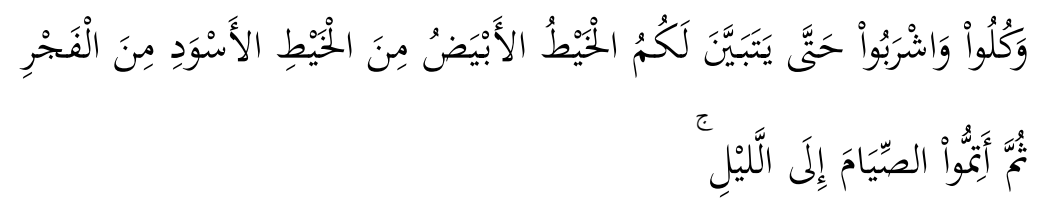

"dan makan minumlah hingga terang bagimu benang putih dari benang hitam, yaitu fajar, kemudian sempurnakanlah puasa itu sampai (datang) malam."91

Dengan demikian, ibadah puasa dalam ajaran Islam pada hakikatnya إمساك (menahan) dan melambangkan kontrol diri berlatih untuk mengekang kedua dorongan yang ada pada dirinya, yaitu menahan diri dari makan minum (dorongan mempertahankan hidup) dan bersenang-senang (dorongan libido seksualis) dengan istrinya dari sejak terbit hingga terbenamnya matahari semata-mata karena perintah Allah. Inilah rahasia sebenarnya dari ibadah puasa, sekalipun kedua hal yang harus dijauhinya itu adalah miliknya sendiri, yang oleh karena itu halal baginya, namun kalau Allah melarang untuk didekati, baginya tidak ada sikap lain kecuali "sami"naa wa atha 'naa".

${ }^{91}$ QS. al-Baqarah [2]: 187. 
Sementara itu, puasa dalam Islam terbagi menjadi tiga macam, yaitu:

1. Puasa wajib; yang meliputi puasa Ramadlan, puasa kifarat atau puasa denda, puasa nadzar.

2. Puasa sunnah; yang meliputi puasa enam hari buan Syawal, puasa Senin Kamis, puasa hari 'Arafah (9 Dzulhijjah), puasa putih (puaa tanggal 13, 14 dan 15 bulan Qamariyah), puasa bulan Muharram (9 dan 10 Muharram), puasa Sya'ban dan puasa Dawud.

3. Puasa yang diharamkan; yang meliputi puasa dua hari Raya, puasa hari-hari Tasyri', puasa terus menerus sepanjang masa, puasa istri yang suaminya tidak meridlainya, terkecuali puasa Ramadlan.

\section{Kewajiban Puasa}

Puasa dalam perspektif Islam sebagai salah satu pilar rukun Islam yang ketiga dan wajib diamalkan. Maksud puasa di sini adalah puasa di bulan Ramadhan. Hal ini sebagaimana firman Allah berikut:

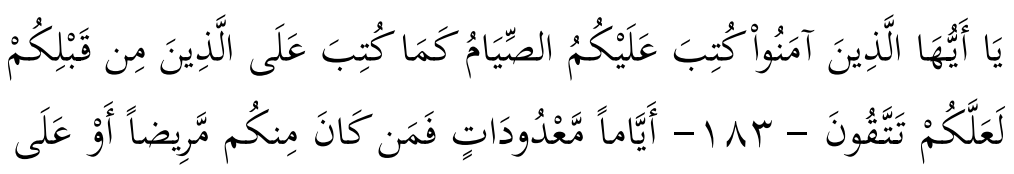




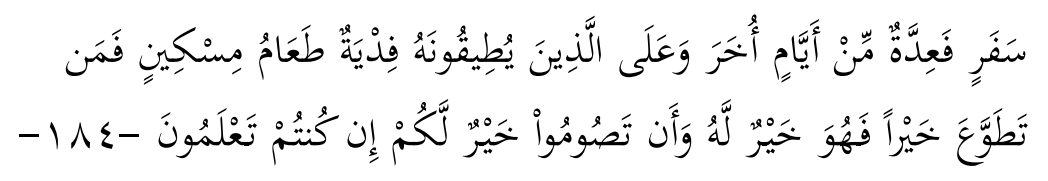

"Hai orang-orang yang beriman, diwajibkan atas kamu berpuasa sebagaimana diwajibkan atas orang-orang sebelum kamu agar kamu bertakwa, (yaitu) dalam beberapa hari yang tertentu, maka barangsiapa diantara kamu ada yang sakit atau dalam perjalanan (lalu ia berbuka), maka (wajiblah baginya berpuasa) sebanyak hari yang ditinggalkan itu pada hari-hari yang lain, dan wajib bagi orang-orang yang berat menjalankannya (jika mereka tidak berpuasa) membayar fidyah, (yaitu): memberi makan seorang miskin. Barangsiapa yang dengan kerelaan hati mengerjakan kebajikan, maka itulah yang lebih baik baginya. dan berpuasa lebih baik bagimu jika kamu mengetahui. ${ }^{92}$

Lafadz:

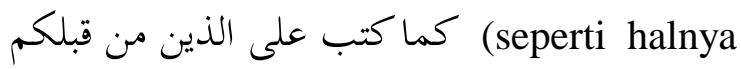

diwajibkan kepada umat sebelum kamu (umat Muhammad)) pada ayat di atas, menunjukkan kewajiban puasa juga ditujukan kepada umatnya nabi-nabi terdahulu mulai nabi Adam as. Kemudian, Imam ath-Thabari menjelaskan bahwa lafadz أَيَّاماً مَّعْدودَاتٍات , sudah mengandung kejelasan bahwa yang dimaksud adalah hari di bulan Ramadlan, dan tidak ada berita yang menyebutkan bahwa umat Islam dikenakan

${ }^{92}$ QS. al-Baqarah [2]: 183-184. 
kewajiban puasa sebelum bulan Ramadlan ini kemudian dihapus dengan datangnya perintah puasa Ramadlan. Karena Allah telah menjelaskan dalam firman-Nya bahwa Dia telah mewajibkan hanya puasa Ramadlan bagi umat Islam. ${ }^{93}$

Dengan demikian, puasa Ramadhan adalah suatu kewajiban yang jelas yang termaktub dalam Kitabullah, Sunnah Rasul-Nya dan ijma' kaum muslimin. Hal ini didasarkan pada lafadz كتب عليكم الصيام Q.S al-Baqarah :183 di atas, kemudian lafadz itu diperjelas dengan lafadz selanjutnya اياما معدودات yang menurut Imam ath-Thabari berarti bulan Ramadlan. Hal ini diperkuat oleh riwayat hadits berikut:

$$
\begin{aligned}
& \text { عَنْ ابْنِ عُمَرَ رَضِيَ اللَّهُ عَنْهُمَا قَالَ قَالَ رَسُولُ اللَّهِ صَلَّى اللَّهُ عَلَّهِهِ }
\end{aligned}
$$

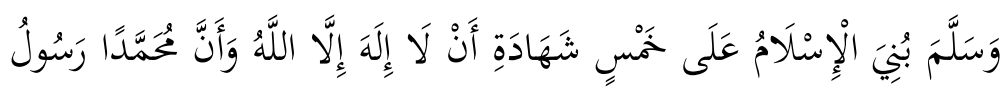

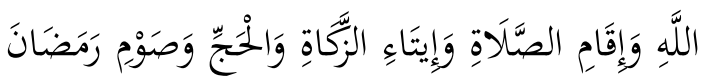

"dari Ibnu Umar berkata: Rasulullah SAW. bersabda: "Islam dibangun di atas lima (landasan); persaksian tidak

${ }^{93}$ Abu Ja`Far Ath-Thabari, Jami`al-Bayan fi Ta`wil al-Qur`an, jilid I, (Beirut: Daar Al Kutub Al Ilmiah, 1992), h. 86. 
ada ilah selain Allah dan sesungguhnya Muhammad utusan Allah, mendirikan shalat, menunaikan zakat, haji dan puasa Ramadlan". ${ }^{94}$

\section{Tujuan dan Fungsi Puasa}

Berdasarkan uraian sebelumnya, dapat dipahami bahwa tujuan dari disyariatkannya puasa bagi orang beriman adalah membentuk pribadi yang bertakwa, bukan hanya sekedar melatih untuk meninggalkan makan dan minum. Hal ini sebagaimana didasarkan pada firman Allah dalam Alquran ayat 183 . Dengan demikian, tujuan ibadah puasa adalah untuk mencapai derajat takwa. Orang yang bertakwa adalah orang yang imannya senantiasa aktif membentuk dirinya, sehingga dia tetap istiqamah (konsisten) dalam beribadat, berakhlak mulia dan terjauh dari segenap dosa dan maksiat.

Sementara fungsi ibadah puasa dalam kehidupan manusia, diantaranya adalah:

a. Bisa memasukkan kita ke dalam surga jika kita telah mati.

b. Melatih sabar, pengendalian diri, disiplin, jujur, emosi, dll

c. Mempersempit jalan aliran darah di mana setan berlalulalang.

${ }^{94}$ HR. al-Bukhari: 7. 
d. Mempererat tali silaturahmi dengan sahur dan buka puasa bersama.

e. Menghilangkan dosa di antara manusia dengan saling maaf-memaafkan di hari lebaran idul fitri kembali ke fitrah manusia.

\section{Hikmah Puasa}

Beberapa hikmah ibadah puasa, diantaranya adalah:

a. Puasa sebagai sarana meraih ketakwaan. ${ }^{95}$

b. Melatih seseorang untuk mengekang dan mengarahkan jiwanya, sehingga dia dapat membimbingnya kepada halhal yang baik bagi jiwanya dan yang dapat memberikan kebahagiaan di dunia dan akhirat. Dan dia menjauhkan dirinya dari menjadi manusia yang menyerupai binatang yang tidak dapat mengontrol dan menahan dirinya dalam memenuhi hawa nafsu dan keinginan-keinginannya.

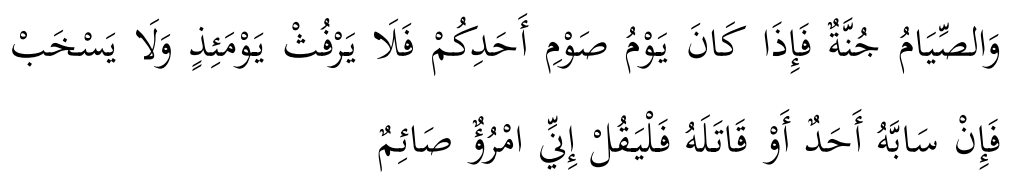

"Dan puasa itu adalah perisai. Apabila kamu puasa, maka janganlah kamu merusak puasamu dengan rafats, dan jangan pula menghina orang. Apabila kamu dihina orang

${ }^{95}$ QS. al-Baqarah [2]: 183. 
atau pun diserang, maka katakanlah, 'Sesungguhnya saya sedang berpuasa."' 96

c. Allah melipatgandakan pahalanya untuk orang yang berpuasa dengan tanpa batas.

$$
\begin{aligned}
& \text { عَنْ أَبِي هُرَيْرَة قَالَ قَالَ رَسُولُ اللَّهِ صَلَّى اللَّهُ عَلَيْهِه وَسَالَّمَ كُكلُّ عَمَلِ ابْنِ }
\end{aligned}
$$

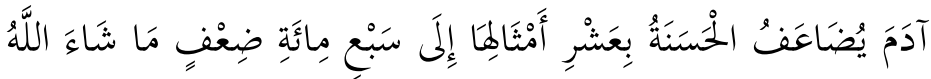

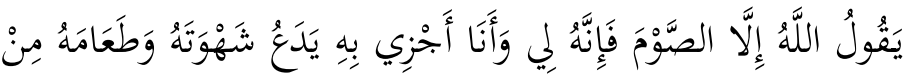

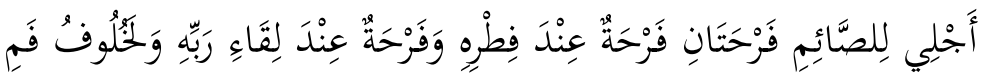

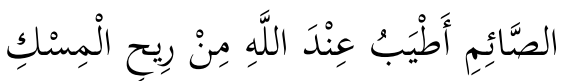

"dari Abu Hurairah ia berkata, "Rasulullah shallallahu 'alaihi wasallam bersabda: "Setiap amal anak Adam akan dilipat gandakan, satu kebaikan menjadi sepuluh hingga tujuh ratus kebaikan sekehendak Allah, Allah berfirman, "Kecuali puasa, puasa adalah untuk-Ku dan Aku yang akan membalasnya, ia tinggalkan makan dan minumnya karena Aku. Orang yang berpuasa itu mempunyai dua kebahagiaan, satu kebahagiaan ketika tiba waktu berbuka, dan satu kebahagiaan lagi ketika berjumpa dengan Rabbnya. Dan sungguh, bau mulut orang yang berpuasa di sisi Allah lebih harum dari bau minyak kesturi. "97

${ }^{96}$ HR. Muslim: 1944.

${ }^{97}$ HR. Ibnu Majah nomor hadits 1628. 
d. Do`a orang yang berpuasa tidak ditolak. ${ }^{98}$

Juga diperkuat dalam riwayat hadits berikut:

$$
\begin{aligned}
& \text { عَنْ أَبَي هُرَيْرَة قَالَ قَالَ رَسُولُ اللَّهِ صَلَّى اللَّهُ عَلَيْهِه وَسَلَّمَمَ مَنْ صَامَ }
\end{aligned}
$$

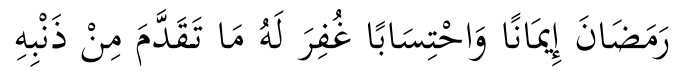

"dari Abu Hurairah berkata; Rasulullah shallallahu 'alaihi wasallam bersabda: "Barangsiapa yang berpuasa karena iman dan mengharap pahala, maka diampuni dosa-dosanya yang telah lalu".99

e. Orang yang berpuasa mempunyai dua kebahagiaan, yaitu apabila ia berbuka puasa ia gembira karenanya, dan apabila ia bertemu dengan Rabb-nya ia bahagia karena puasanya.

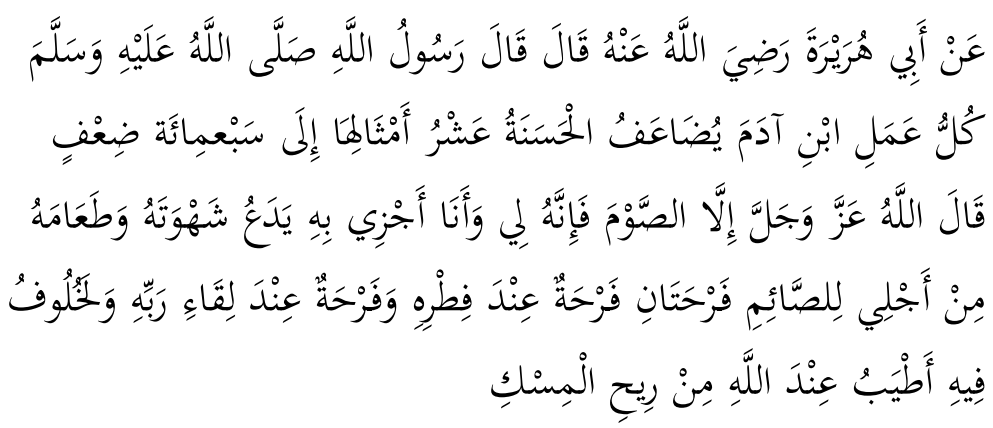

"dari Abu Hurairah radliallahu 'anhu, ia berkata; Rasulullah shallallahu 'alaihi wasallam bersabda: "Setiap amal anak Adam dilipatgandakan pahalanya. Satu macam kebaikan diberi pahala sepuluh hingga tujuh ratus kali. Allah 'azza wajalla berfirman; 'Selain puasa, karena puasa

${ }^{98}$ HR. Al Baihaqi, 3/345. As-Silsilah Ash-Shahihah, 1797

${ }^{99}$ HR. al-Bukhari nomor hadits: 36 \& 37, HR. Muslim: 1268. 
itu adalah bagi-Ku dan Akulah yang akan memberinya pahala. Sebab, ia telah meninggalkan nafsu syahwat dan nafsu makannya karena-Ku.' Dan bagi orang yang berpuasa ada dua kebahagiaan. Kebahagiaan ketika ia berbuka, dan kebahagiaan ketika ia bertemu dengan RabbNya. Sesungguhnya bau mulut orang yang berpuasa lebih wangi di sisi Allah daripada wanginya kesturi.

f. Puasa dapat memberikan syafa`at pada hari Kiamat kepada orang yang berpuasa

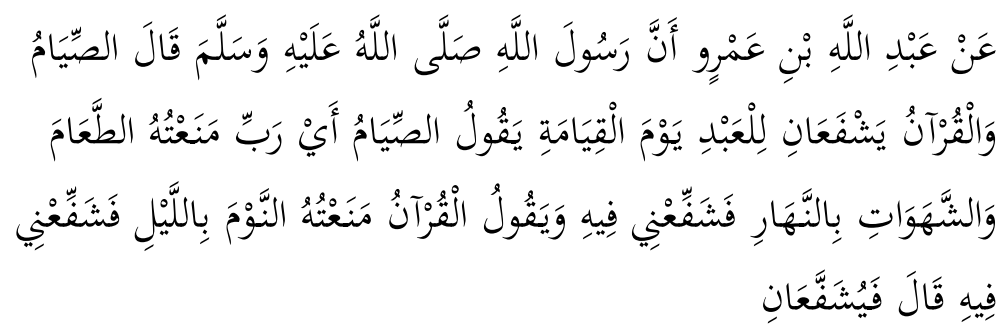

"dari Abdullah bin 'Amru, bahwa Rasulullah Shallallahu 'alaihi wa Salam bersabda: "Puasa dan Al Qur'an kelak pada hari kiamat akan memberi syafa'at kepada seorang hamba. Puasa berkata: Duhai Rabb, aku telah menahannya dari makanan dan nafsu syahwat di siang hari, maka izinkahlah aku memberi syafa'at kepadanya. Dan Al Qur'an berkata: aku telah menahannya dari tidur di malam hari, maka izinkanlah aku memberi syafa'at kepadanya. Beliau melanjutkan sabdanya: maka mereka berdua (puasa dan Al Qur'an) pun akhirnya memberi syafa'at kepadanya." 101

100 HR. Muslim: 1945.

${ }^{101}$ HR. Ahmad: 6337 
g. Mendapatkan surga ar-Rayyan

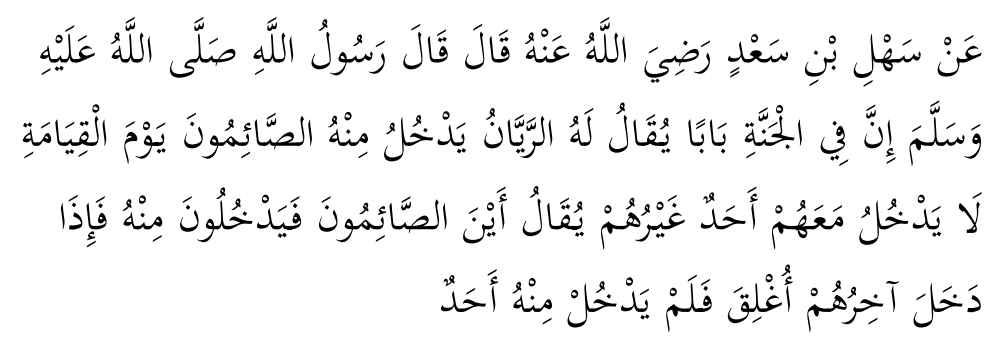

"Dari Sahl bin Sa'd radliallahu 'anhu, ia berkata; Rasulullah shallallahu 'alaihi wasallam bersabda: "Di dalam surga ada satu pintu yang disebut Ar Rayyan. Orang-orang yang diperkenankan masuk surga melalui pintu pada hari kiamat kelak hanyalah orang-orang yang berpuasa, sedangkan yang lainnya tidak diperkenankan. Mereka akan dipanggil; 'Manakah orang-orang yang sering berpuasa? ' Dan bila orang yang terakhir dari mereka telah masuk, maka pintu itu pun segera ditutup, hingga tak seorang pun yang dapat memasukinya." 102

\section{Pengaruh Puasa dalam pembentukan Insan}

\section{berkarakter}

Puasa dan pembentukan insan karakter dapat dipahami dari makna surat al-Baqarah ayat 183. Dalam ayat tersebut ada beberapa kata kunci terkait pembentukan insan karakter melalui ibadah puasa, yaitu (1) orang yang beriman; (2) diwajibkan atas kamu berpuasa; dan (3) menjadi orang yang bertakwa.

${ }^{102}$ HR. Muslim: 1947. 
Ketiga kata kunci tersebut di atas, jika dihubungkan, maka akan melahirkan pribadi yang istiqomah dan konsisten dalam keimanannya. Hal ini ditunjukkan, ketika sesorang mengakui bahwa ia telah beriman, maka secara otomatis ia akan melaksanakan puasa Ramadhan karena puasa Ramadhan merupakan perintah dari Allah yang dibawa oleh Rasul-Nya dan tertulis dalam kitab-Nya. Berarti hubungan sangat jelas sekali. Kemudian, bagaimana hubungannya dengan takwa? apakah setelah seseorang menjalan puasa Ramadhan, ia sudah bisa dikatakan bertakwa?

Sebelum dijawab pertanyaan ini, mari dilihat sifat-sifat orang yang bertakwa dalam al-Qur'an, agar diketahui seperti apakah orang yang bertakwa itu. Al-Qur'an menjelaskan sifatsifat orang yang bertakwa, diantaranya:

1. al-Baqarah (2): 177 , sifat orang yang bertakwa adalah: menepati janji, sabar, benar/jujur.

2. Ali imran (3) : 102-103, sifat orang yang bertakwa adalah: menjalin siraturrahim, dan syukur, menjaga diri.

3. Ali imran (3) : 133-135, sifat orang yang bertakwa adalah: kepedulian sosial, mengendalikan diri (menahan amarah), pemaaf, berbuat kebaikan, bertaubat. 
4. al- Ahzab (33) : 35, sifat orang bertakwa adalah: taat, benar/jujur, sabar, khusyu', bersedekah (kepedulian sosial), memelihara diri, zikir

Ayat-ayat di atas, menjelaskan sifat orang bertakwa adalah: ikhlas, tawadu', penyayang, tanggung jawab, amanah dan lain-lain. Dengan demikian, ketika Allah mewajibkan orang beriman untuk melaksanakan puasa khususnya puasa ramadhan seharus dapat melahirkan sifat-sifat di atas, bukan hanya sekedar sebatas kewajiban tapi yang paling penting adalah pembentukan karakter kejiwaan dengan menampilkan sifat-sifat tersebut dalam kehidupan sehari hari. Ramadhan merupakan "Madrasah Spiritual" karena di dalam pelaksanaan ibadah tersebut banyak mengajarkan nilai-nilai kebaikan dalam upaya pembentukan pribadi yang takwa. Jika ini semua bisa terbentuk maka apa yang diharapakan oleh Allah dalam surat al-Baqarah ayat 183 bisa bisa terwujud. Sebaliknya, melaksanakan puasa Ramadlan, tetapi tidak bisa melahirkan sifat-sifat di atas, maka bisa dikatakan puasanya tidak memiliki arti atau makna. Hal ini yang khawatirkan oleh Nabi SAW dalam riwayat berikut:

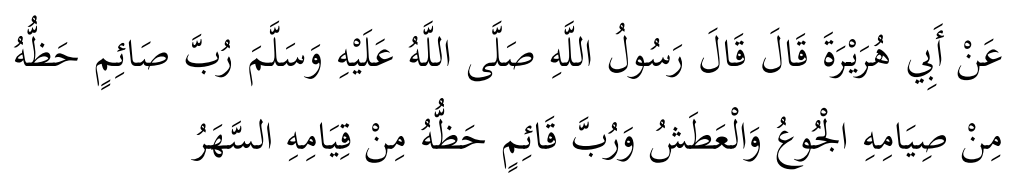


“dari Abu Hurairah berkata; Rasulullah shallallahu 'alaihi wasallam bersabda: "Berapa banyak orang yang berpuasa tidak mendapatkan bagian dari puasanya melainkan lapar dan dahaga." 103

\section{Makna Spiritual Puasa}

Puasa sebagaimana ibadah-ibadah lainnya, berfungsi membentuk keperibadian yang suci dan bersih, yang populer disebut Imtaq (iman dan taqwa). Ini, tercermin dalam kandungan ayat al-Qur'an yang memerintahkan puasa. ${ }^{104}$ Ayat itu didahului dengan panggilan "hai orang-orang yang beriman". Ini, berarti puasa itu haruslah didahului dengan suatu keimanan, yaitu suatu kepercayan yang membulat dan kokoh, bahwa Allah, Rasul, al-Qur'an dan Sunnah serta keberadaan alam akhirat dengan aneka ragamnya adalah mutlak kebenarannya. Dan kemudian diakhiri dengan katakata "taqwa", yang bermakna melaksanakan semua perintah dan menjauhi semua larangan Allah Swt.

Firman Allah dalam surah al-Baqarah ayat 183, menggunakan kalimat panggilan: يَأَيُهَا الَّنِينَ (hai orang-orang yang beriman). Huruf " $y a$ "” di sini merupakan huruf nida'

103 HR. Ahmad: 8501.

${ }^{104}$ QS. al-Baqarah [2]: 183. 
yang berarti seruan kepada orang banyak. lafadz آمَنُو آن sebagai na'at dari pada lafadz الذين, sehingga seruan ini dikhususkan

kepada orang yang beriman saja baik laki-laki atau perempuan. Ini, berarti puasa itu haruslah didahului dengan suatu keimanan, yaitu suatu kepercayan yang membulat dan kokoh, bahwa Allah, Rasul, al-Qur'an dan Sunnah serta keberadaan alam akhirat dengan aneka ragamnya adalah mutlak kebenarannya. Dan kemudian diakhiri dengan katakata "taqwa", yang bermakna melaksanakan semua perintah dan menjauhi semua larangan Allah SWT.

Persoalannya adalah apakah kita merasa dipanggil atau diseru oleh Allah dengan seruan يَا أيَّهَا اللَّذِينَ آَنُوُ atau tidak?

Adalah para sahabat Rasulullah yang jika dibacakan kepada mereka ayat yang dimulai dengan lafadz

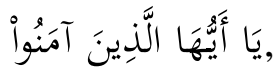

maka mereka akan pasang telinga. Mengapa? Karena setelah seruan itu, pasti ada sesuatu hal penting yang perlu diperhatikan. Ada 2 (dua) hukum yang bisa diambil dari ayat di atas, yaitu pertama, sebagai bentuk self-assesment (penilaian sendiri), apakah termasuk orang beriman atau tidak? Kedua, sebagai titik perubahan, maksudnya jika di bulan Ramadhan tidak ada perbaikan yang dilakukan, maka 
tidak akan pernah berubah menjadi lebih baik sampai bertemu dengan Ramadhan tahun depan (kalau bertemu).

Oleh karena itu, tatkala seruan QS. al-Baqarah ayat 183 tersebut didengungkan, maka maksudnya adalah :

a. Wahai hati orang-orang beriman! Mampukah panggilan ini menggetarkan atau menggelegarkan hati kita karena ada sesuatu yang perlu diperhatikan dan diamalkan. Sebagaimana firman Allah berikut:

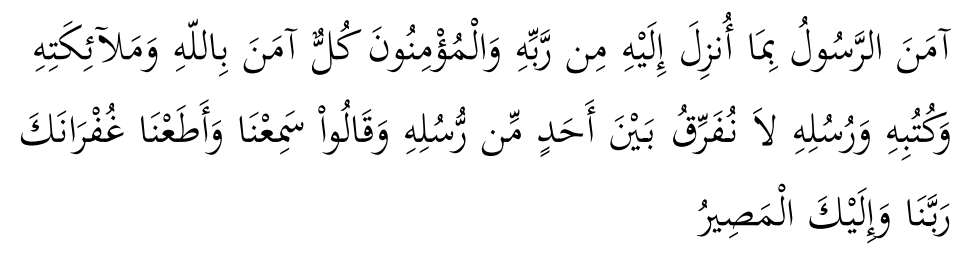

"Rasul telah beriman kepada Al Quran yang diturunkan kepadanya dari Tuhannya, demikian pula orang-orang yang beriman. Semuanya beriman kepada Allah, malaikatmalaikat-Nya, kitab-kitab-Nya dan rasul-rasul-Nya. (mereka mengatakan): "Kami tidak membeda-bedakan antara seseorangpun (dengan yang lain) dari rasul-rasulNya", dan mereka mengatakan: "Kami dengar dan Kami taat." (mereka berdoa): "Ampunilah Kami Ya Tuhan Kami dan kepada Engkaulah tempat kembali." 105

b. Panggilan "Amanu" merupakan panggilan kasih sayang/cinta dari Allah kepada kita. Karena Hidayah dan Iman itu merupakan anugerah terbesar dari Allah kepada manusia.

${ }^{105}$ QS. al-Baqarah [2]: 285. 
c. Orang yang beriman mensikapi seruan Allah terkait dengan puasa itu dengan ukuran cinta pula. Artinya, setiap apa yang akan diperintahkan oleh Allah, meskipun perintah itu terasa berat, maka disikapi dengan kegembiraan karena orang yang beriman senantiasa dalam ikatan keimanan dengan Allah swt. Sehingga berpuasa akan terasa ringan dan rindu.

d. Allah tidak mensyariatkan puasa kepada orang yang tidak beriman, karena mereka tidak terikat dengan ikatan iman.

Kecintaan kepada Allah merupakan esensi keimanan seseorang kepada Allah. Nabi SAW. menegaskan:

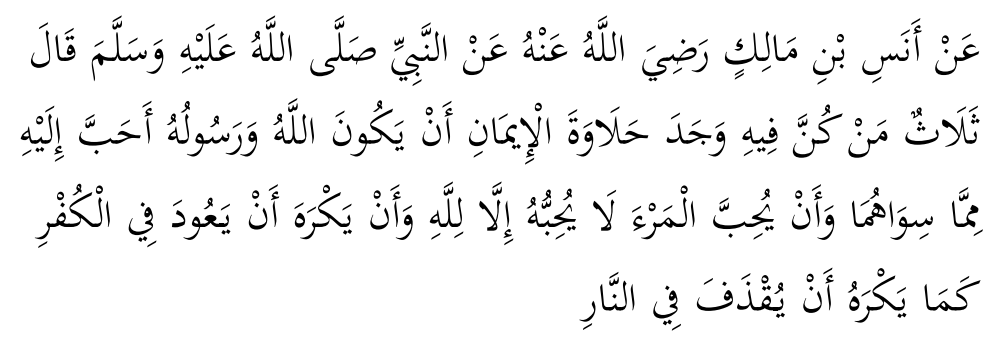

"Dari Anas bin Malik dari Nabi saw., beliau bersabda: "Tiga perkara yang apabila ada pada diri seseorang, ia akan mendapatkan manisnya iman: (1) Dijadikannya Allah dan Rasul-Nya lebih dicintainya dari selain keduanya. (2) Jika ia mencintai seseorang, dia tidak mencintainya kecuali karena Allah. (3) Dan dia benci 
kembali kepada kekufuran seperti dia benci bila dilempar ke neraka". ${ }^{106}$

Ibnu Hajar al-Asqalani mengatakan: orang yang sempurna imannya pasti mengetahui, bahwa hak Allah dan Rasul-Nya lebih kuat untuk diperhatikan (didahulukan) olehnya daripada hak ayah-ibu dan istrinya serta seluruh manusia. Sebagai tanda cintanya kepada Allah adalah membela agama Allah serta berupaya menerapkan syari'atNya dan berakhlak dengan akhlaq-Nya. ${ }^{107}$

Sementara, Andul Munir Mulkhan, memaknai ibadah puasa Ramadhan adalah tumbuhnya rasa kemanusiaan, sehingga inti puasa adalah menahan hawa nafsu yang harus diikuti aksi sosial profetik. ${ }^{108}$

\section{Rangkuman}

1. Ibadah puasa hakikatnya adalah أمساك (menahan) dan melambangkan kontrol diri berlatih menahan diri dari makan, minum, dan hubungan biologis dengan niat

106 HR. al-Bukhari: 15

${ }^{107}$ Ibnu Hajar al-Asqalani, Fathul Bārī, (Jakarta: Pustaka Azzam, 2011), h. 193.

${ }^{108}$ Abdul Munir Mulkhan, Puasa, Jihad Melawan Kemiskinan dalam Fitrah dan Ibadah Kurban (Nabinya Mustadl'afin), (Yogyakarta: Mitro, 2012), h. 44. 
ta'abbudi, dari sejak terbit hingga terbenamnya matahari semata-mata karena perintah Allah.

2. Syariat puasa (puasa di bulan Ramdlan) diwajibkan atas kaum muslimin dengan dasar QS. al-Baqarah ayat 183-185 dan hadits riwayat al-Bukhari nomor hadits 7. Syariat puasa juga pernah diwajibkan pula kepada umat umatnya nabi-nabi terdahulu mulai nabi Adam as.

3. Tujuan dari disyariatkannya puasa bagi orang beriman adalah membentuk pribadi yang bertakwa. Sementara fungsi ibadah puasa dalam kehidupan manusia diantaranya: melatih sabar, pengendalian diri, disiplin, jujur, dan emosi,

4. Beberapa hikmah ibadah puasa, diantaranya adalah (a) sebagai sarana meraih ketakwaan, (b) melatih mengekang dan mengarahkan jiwanya kepada hal-hal yang baik, (c) Allah melipatgandakan pahalanya untuk orang yang berpuasa dengan tanpa batas, (d) do`a orang yang berpuasa tidak ditolak, (e) orang yang berpuasa mempunyai dua kebahagiaan, yaitu apabila ia berbuka puasa ia gembira karenanya, dan apabila ia bertemu dengan Rabb-nya, (f) puasa dapat 
memberikan syafa'at pada hari Kiamat kepada orang yang berpuasa, dan (g) mendapatkan surga ar-Rayyan.

5. Puasa membentuk karakter muttaqin dengan memiliki sifat-sifat orang yang bertakwa, di antaranya: menepati janji, sabar, benar/jujur, menjalin siraturrahim, syukur, menjaga diri, kepedulian sosial, mengendalikan diri (menahan amarah), pemaaf, berbuat kebaikan, bertaubat, taat, benar/jujur, sabar, khusyu', bersedekah (kepedulian sosial), memelihara diri, dan zikir.

\section{Latihan/Tugas/Eksperimen}

Mahasiswa mengerjakan tugas:

1. Mendiskusikan tentang sifat-sifat orang yang bertakwa, di antaranya: menepati janji, sabar, benar/jujur, menjalin siraturrahim, syukur, menjaga diri, kepedulian sosial, mengendalikan diri (menahan amarah), pemaaf, berbuat kebaikan, bertaubat, taat, benar/jujur, sabar, khusyu', bersedekah (kepedulian sosial), memelihara diri, dan zikir.

2. Mengidentifikasi ayat dan hadits terkait sifat-sifat orang yang bertaqwa tersebut. 
3. Mendiskusikan pula upaya untuk menampilkan sifatsifat tersebut dalam kehidupan sehari hari.

\section{DAFTAR PUSTAKA}

Al-Asqalani, Ibnu Hajar, Fathul Bārī, Terj. Amiruddin, Jakarta: Pustaka Azzam, 2011.

Ath-Thabary, Imam Abu Ja'far bin Jarir, Jami'ul Bayan Fi Ta'wil Al Quran, Beirut: Daar al-Kutub al-'ilmiah, 1992.

Compact Disc (CD) Ensiklopedi Hadits 9 Imam.

Departemen Agama RI, Al-Qur'an dan Tafsirnya, Jakarta: Departemen Agama RI, 2010.

Mulkhan, Abdul Munir, Puasa, Jihad Melawan Kemiskinan dalam Fitrah dan Ibadah Kurban (Nabinya Mustadl'afin), Yogyakarta: Mitro, 2012.

Sabiq, Sayyid, Fiqih Sunnah, Jakarta: Pena Pundi Aksara, 2006. 


\section{BAB IV \\ HAJI DAN MAKNA SPIRITUALNYA DALAM \\ KEHIDUPAN}

\section{A. Pendahuluan}

Tahun 2015, kuota haji Indonesia menempati posisi tertinggi di dunia, yakni 15-25\% dari seluruh jumlah jamaah Haji di Arab Saudi. ${ }^{109}$ Tinggi jumlah minat muslim Indonesia dalam menunaikan rukun Islam kelima ini, secara personal menunjukkan tingginya tingkat ekonomi masyarakat Indonesia. Di sisi lain, munculnya sebuah keyakinan dari sebagian masyarakat muslim, bahwa dengan berhaji berkalikali merupakan bagian dari usaha mensempurnakan keislamannya, sehingga mendorong seseorang untuk berlomba-lomba berangkat haji.

Kenyataan inilah yang membuat Yusuf Qardhawi mengkritik terhadap kondisi paradok tersebut dengan pernyataannya: "Betapa banyak orang yang telah berkali-kali Haji, tetapi tidak memiliki kepekaan sosial terhadap manusia yang membutuhkan. Banyak orang tidak bisa makan,

${ }^{109}$ Komisi Pengawas Persaingan Usaha Republik Indonesia, Evaluasi Kebijakan Pemerintah Terkait dengan Persaingan Usaha dalam Rancangan Perubahan Undang-undang No 17/1999 tentang PenyelenggaraanHaji. Diakses dari www.kppu.go.id 
berpakaian dengan layak, tidak memiliki tempat tinggal. Di sisi lain harus berhaji berkali-kali. Haji hanyalah bersifat kesalehan individu, sedangkan urusan umat jauh harus diutamakan". 110

Oleh karena itu, diperlukan pencerahan tentang hakikat dan makna spiritual ibadah haji dalam kehidupan sosial, sehingga umat Islam tidak hanya mengejar ritualitas belaka yang kosong akan makna dan implementasinya. Berdasar hal tersebut, capaian pembelajaran pada bab keempat ini diharapkan mahasiswa dapat memahami: (1) hakikat haji; (2) sejarah haji; (3) kriteria haji mabrur; (4) hikmah haji; dan (5) makna spiritual haji bagi kehidupan sosial.

\section{B. Penyajian Materi}

\section{Hakikat Haji}

Haji adalah salah satu rukun Islam yang kelima. Hal ini berdasarkan hadits berikut:

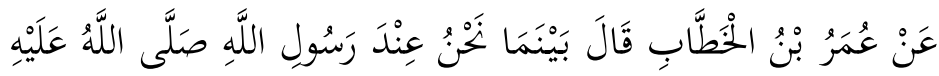

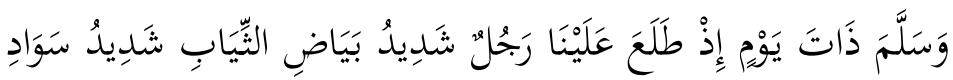

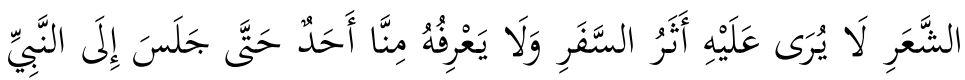

${ }^{110}$ Yusuf Qardhawi, Fiqh Prioritas, cet. ke-2. Jakarta: Gema Insani Press, 1997. 


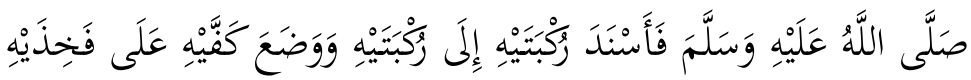

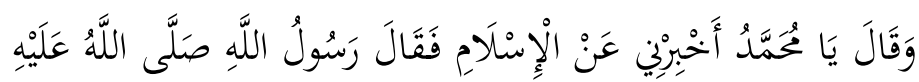

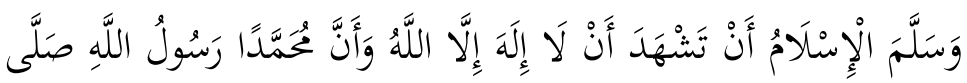

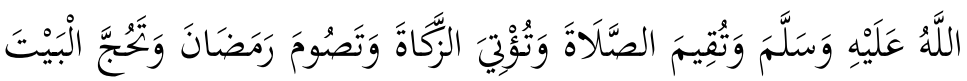
إِنْ اسْتَطْعْتَ إلَيْهِ سَبِياًا.

"dari shahabat "Umar r.a. : "Tengah kami duduk pada suatu hari bersama-sama Rasulullah saw., datanglah seorang laki-laki, putih bersih pakaiannya, hitam bersih rambutnya, tak terkesan padanya tanda orang sedang bepergian dan tiada seorangpun di antara kami yang mengenalnya; kemudian ia bersimpuh dihadapan Nabi saw. dengan merapatkan kedua lututnya pada dua lutut Nabi dan meletakkan kedua telapak tangannya pada paha Nabi. Lalu ia berkata: "Hai Muhammad, terangkanlah padaku tentang Islam!”. Nabi menjawab: "Islam, ialah engkau mempersaksikan: tiada Tuhan selain Allah dan Muhammad adalah utusan Allah, mengerjakan shalat, membayar zakat, berpuasa Ramadhan dan pergi Haji bila engkau mampu melakukannya". ${ }^{111}$

${ }^{111}$ HR. Muslim: 9. 
Secara estimologi (bahasa), Haji berarti niat (القصد).

Sedangkan menurut syara' berarti ibadah berkunjung ke tempat-tempat tertentu di Tanah Suci pada suatu masa tertentu, untuk dengan sengaja mengerjakan beberapa amal ibadah dengan syarat-syarat tertentu dan atas dasar menunaikan panggilan perintah Allah SWT dan dengan mengharap ridlaNya. ${ }^{112}$

Temat-tempat tertentu yang dimaksud dalam pengertian haji di atas, adalah Ka'bah, Mas'a (tempat sa'i), Padang Arafah (tempat wukuf), Muzdalifah (tempat mabit), dan Mina (tempat melontar jumroh). Sedangkan yang dimaksud dengan waktu tertentu adalah bulan-bulan haji yaitu dimulai dari Syawal sampai sepuluh hari pertama bulan Dzulhijjah. Amalan ibadah tertentu ialah thawaf, sa'i, wukuf, mazbit di Muzdalifah, melontar jumroh, dan mabit di Mina.

Berkaitan dengan ibadah hajji, Islam sangat jelas memberikan kewajiban berhajji adalah satu kali dan lebihnya adalah sunah. Hal ini berdasarkan hadits :

112 Nasruddin Razak, Dienul Islam, (Bandung, PT. Al Ma'arif, 1996), h. 210. 


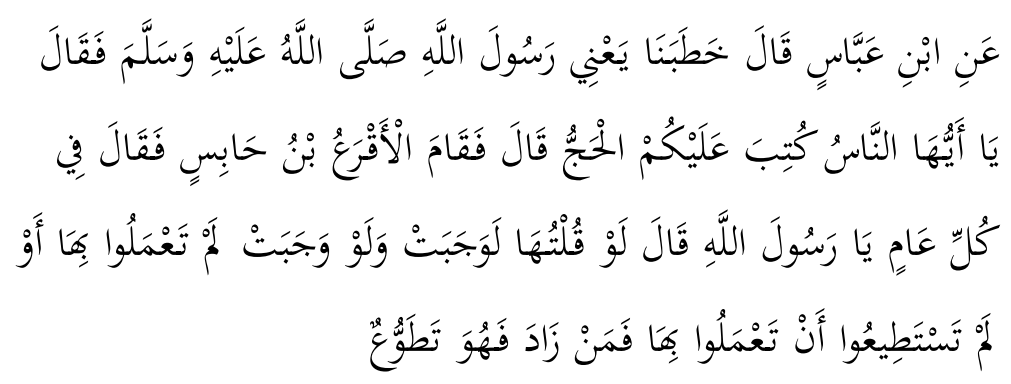

"Dari Ibnu 'Abbas (ia telah berkata): Rasulullah saw. telah berkhutbah kepada kami, yaitu ia berkata: "Sesungguhnya Allah telah mewajibkan atas kamu haji”, lalu berdiri 'Aqra' bin Habis dan bertanya: Apakah di tiap-tiap tahun ya Rasulullah? Sabdanya: Jika aku katakan dia (yakni, kalau aku katakan, niscaya wajib haji pada tiap-tiap tahun) niscaya jadi wajib. Haji itu sekali, maka selebih dari itu adalah tathawwu'."113

Berdasarkan hadits di atas, naik/pergi hajji menurut hukum syara' hukumnya wajib, karena tidak ada dalil yang mengubah kewajiban itu. Dan hal ini sesuai dengan qaidah ushul: "bahwa tiap-tiap perintah yang terdapat dalam AlQur'an atau Hadits Nabi saw. pada asalnya berketetapan wajib". ${ }^{114}$ (Abdul Qadir Hassan, 1992: 32). Masih menurut

${ }^{113}$ HR. Ahmad: 2190, Ad-Darimi: 1722, dan An-Nasaai : 2573.

${ }^{114}$ Abdul Qadir Hassan, Kata Berjawab: Solusi untuk Berbagai

Permasalahan Syariah, (Surabaya: Pustaka Progressif, 2006), h. 32. 
Abdul Qadir Hassan, karena tiap-tiap perintah asalnya cukup dilaksanakan sekali saja. Jadi, pergi hajji cukup dikerjakan sekali saja seumur hidup. Oleh karena tidak ada lain-lain keterangan agama yang mengubah "satu kalinya" itu, maka tetaplah ibadat hajji itu wajibnya hanya sekali seumur hidup dan selebihnya sunnah saja. Oleh karena sunnah, maka مَايُشَنابُ فَاعِلُهُ (apabila dikerjakannya, ia mendapat ganjaran, tetapi jika ditinggalkannya, tidak berdosa).

\section{Sejarah Haji}

Menurut jumhur ulama, ibadah Haji diresmikan menjadi syariah Muhammad saw pada tahun ke enam Hijrah, dan tahun itulah kaum muslimin dengan pimpinan Rasulullah pergi melakukan Umrah, tetapi terhalang oleh kaum Quraisy. Sedangkan pada tahun ke tujuh Nabi pergi melakukan Umrah, pada tahun ke 9 Nabi Muhammad mengangkat Abu Bakar Asshiddiq berangkat dan menjadi ketua rombongan Haji, baru tahun kesepuluh barulah Rasulullah sendiri naik Haji dengan seluruh kaum muslimin yang terkenal dengan Haji Wada' (Haji 
perpisahan $)^{115}$, dan delapan puluh satu hari setelah itu, Rasulullah berpulang ke rahmatullah. ${ }^{116}$

Sejarah Haji tidak bisa terlepas dari sejarah pembangunan Ka'bah seperti yang diperintahkan Allah SWT kepada Nabi Ibrahim as. Ketika Nabi Ibrahim as. selesai membangun Ka'bah, Allah SWT memerintahkannya untuk menyeru manusia agar melaksanakan haji. ${ }^{117}$

Berdasar ayat-ayat tentang perintah wajibnya ibadah haji, dapat dipahami memiliki hubungan dengan sejarah Nabi Ibrahim as dan Nabi Ismail as di Makkah sebagai seruan dari Allah kepada Nabi Ibrahim as beserta putranya Ismail as untuk menyelesaikan pembangunan Ka'bah. "Monumen" bagi keduanya kini adalah Maqam Ibrahim dan Hijr Ismail. Pembangunan Baitullah ini dilakukan oleh Ibrahim as ketika beliau datang ke Mekah untuk yang kelima kalinya sekaligus yang terakhir. Lalu saat peristiwa apa saja Ibrahim as ke Makkah ?

1. Mengantar Siti Hajar dan Ismail

${ }^{115}$ Muhammad al-Khudri Bek, Tarikh Tasyri' Al-Islami, alih bahasa Mhd. Zuhri. (Indonesia: Darul Ikhya, t.t), h. 52.

${ }^{116}$ Nasruddin Umar, hal. 210.

${ }^{117}$ QS. al-Haj [22] : 27-29 dan QS. Ali Imran [3] : 97. 
Ibrahim as, Siti Hajar, dan Ismail as berangkat dari Hebron bergerak ke arah tenggara menyusuri rute kafilah yang dikenal sebagai rute wewangian (incense route) sejauh $1.200 \mathrm{~km}$ dan tiba di lembah tandus pegunungan Sirat yang puncak-puncaknya meliputi Jabal Ajyad, Jabal Qubais, Jabal Qu'aiq'an, Jabal Hiro, dan Jabal Tsur. Lembah itu bernama Bakkah (Mekah). Siti Hajar dan Ismail as diantarkan ke Mekah karena istri tua Ibrahim Siti Sarah mencemburui Hajar yang telah memberikan putra kepada Ibrahim. Atas perintah Allah SWT Siti Hajar dan putranya ditinggal di bawah sebuah pohon oleh Ibrahim as yang kembali ke Palestina menemui Sarah. Nabi Ibrahim as berdoa menengadahkan tangan, menyebut nama Allah, menitipkan Siti Hajar dan Ismail as di bawah perlindungan dan keselamatan Allah SWT.

Saat air susu habis dan tak ada air, Siti Hajar menaiki bukit Shafa mencari air untuk putranya atau kalau-kalau ada kafilah yang dapat membantu. Ketika tak ada siapapun yang lewat, Siti Hajar berjalan menuruni bukit, lembah, dan mendaki ke bukit Marwah. Melihat ke sekeliling namun tak ada apa-apa pula. Tujuh kali balik dilakukan, hingga akhirnya Allah mengeluarkan air zamzam di tempat 
Ismail ditinggalkan. Kelak inilah yang mendasari prosesi haji yang bernama Sai.

2. Menyembelih Ismail as

Saat Ismail berusia 11-12 tahun, Ibrahim as menemui keluarganya di Mekah yang telah berubah dibandingkan situasi saat pertama datang. Baru saja melepas rindu, Allah SWT. memerintahkan melalui mimpi agar menyembelih Ismail as.

Meskipun mengalami kegalauan, namun akhirnya berkat ketaatan Ibrahim as dan kesabaran Ismail as, "yaa abati af'al maa tu'maru" - wahai ayahku kerjakanlah apa yang diperintahkan kepadamu, maka perintah itu dapat dilaksanakan. Allah pun menggantikannya dengan sembelihan Qibas (salah satu jenis kambing).

Soal ujian pengorbanan dalam bentuk apapun, Allah sebenarnya tidak bermaksud menganiaya hamba-hambaNya, melainkan sekadar "sarana" untuk meningkatkan mutu keimanan dan amal salehnya semata. Dalam ibadah haji, penyembelihan hewan "hadyu" ini dilaksanakan setelah Jumratul Aqabah atau pada hari-hari tasyrik. 
3. Mengganti palang pintu rumah

Setelah Ismail as berumah tangga dengan memperistri wanita dari suku Jurhum dan Siti Hajar telah meninggal, Ibrahim as datang bersilaturahmi. Namun tidak bertemu dengan putranya karena sedang berburu dalam waktu yang cukup lama. Hanya menantunya yang ada, namun Ibrahim merahasiakan identitas dirinya. Ketika ditanyakan bagaimana keadaan rumah tangga mereka, istri Ismail as tersebut mengeluh tentang kesulitan dan kemiskinan hidup mereka, serta tak ada kebahagiaan sama sekali. Ketika pamit, Ibrahim berpesan kepada menantunya jika Ismail pulang sampaikan salam dan disarankan agar mengganti palang pintu rumahnya. Ketika Ismail as kembali, lalu mendengar cerita istrinya tentang kedatangan tamu beserta pesan-pesannya itu, maka Nabi Ismail as mengerti. Kemudian ia segera menceraikan istrinya yang dinilai rewel, tak bersyukur atas nikmat yang Allah berikan, tidak sabar, serta tidak menghargai usaha suaminya tersebut.

\section{Mempertahankan palang pintu rumah}

Setahun setelah kedatangan ketiga, Ibrahim as datang lagi ke Mekah untuk menemui putranya, lagi-lagi tak bertemu. Hanya istri Ismail as yang baru yang ditemui. Ia 
adalah putri sekh suku Jurhum yang bernama As Sayyidah binti Madad bin Amr. Sebagaimana yang lalu, Ibrahim as yang menyembunyikan identitas dirinya, menanyakan pula keadaan rumah tangga mereka.

Ibrahim berdoa "Ya Allah berkahi daging dan air mereka." 118 . Seraya berpesan apabila suaminya pulang nanti agar palang pintunya tak perlu diganti. Demikianlah istri saleh yang senantiasa bersyukur dan tak pernah mengeluh atas hasil usaha suaminya.

Meskipun kedatangan ketiga dan keempat tidak berhubungan dengan ibadah haji, namun bangunan rumah tangga merupakan indikator kesuksesan haji. Hal ini sejalan dengan doa agar sekembalinya dari melaksanakan ibadah haji senantiasa mendapat perlindungan Allah dari "suu il munqolabi fiil maali wal ahli" (kejelekan harta dan keluarga).

5. Membangun Ka'bah

Tanah yang menggunduk agak tinggi dekat sumur zamzam adalah lokasi pilihan "Ini adalah tempat yang

${ }^{118}$ HR. Bukhori 
dipilih Allah, ${ }^{\prime 119}$ kata Ibrahim as kepada Ismail as (HR Bukhari), lalu keduanya membangun Ka'bah itu. Berbeda dengan bangunan Ka'bah sekarang, dahulu Ka'bah lebih pendek, tak berpintu, serta memanjang meliputi Hijr Ismail sekarang. Ada dua batu istimewa dalam proses pembangunan tersebut, yaitu Hajar al Aswad dan Maqam Ibrahim. Nantinya dalam ritual haji Hajar Aswad menjadi tempat mengawali dan mengakhiri tawaf. Setiap melewatinya mengecup atau ber-istilam. Adapun setelah tawaf, jemaah haji mesti salat 2 (dua) rakaat di belakang Maqam Ibrahim. Allah SWT pun berfirman, “dan sucikanlah rumah-Ku ini bagi orang-orang yang tawaf, orang-orang yang beribadah, dan orang-orang yang ruku-sujud. ",20

Kita mengira bahwa Ibrahim as akan meluangkan waktu panjang di Mekah, namun nyatanya tidak, setelah Ka'bah dibangun, Ibrahim as kembali ke Bersyeba Palestina. Sebelumnya itu, Allah menyuruh Ibrahim as untuk mengumumkan kewajiban ibadah haji, berziarah ke

${ }^{119} \mathrm{HR}$. Bukhori
${ }^{120}$ QS. al-Hajj [22] : 26 
Baitullah dengan tata cara (manasik) yang diajarkan Allah kepada Ibrahim a.s. ${ }^{121}$

\section{MASA NABI MUHAMMAD SAW}

\section{Haji di Era Rasulullah}

Ibadah haji seperti yang sekarang ini merupakan syariat yang dibawa oleh Nabi Muhammad SAW, sebagai langkah memperbaharui dan menyambung ajaran Nabi Allah Ibrahim as. Ibadah haji mula diwajibkan kepada umat Islam pada tahun ke-6 Hijrah, mengikuti turunnya QS Al-Imran 97. Pada tahun tersebut, Rasulullah SAW bersama-sama lebih kurang 1500 orang berangkat ke Makkah untuk menunaikan fardhu haji tetapi tidak dapat mengerjakannya karena dihalangi oleh kaum kafir Quraisy sehingga melahirkan satu perjanjian yang dinamakan Perjanjian Hudaibiah. Perjanjian itu membuka jalan bagi perkembangan Islam di mana pada tahun berikutnya (tahun ke-7 Hijrah ), Rasulullah telah mengerjakan Umrah bersama-sama 2000 orang umat Islam. Pada tahun ke9 Hijrah, barulah ibadah Haji dapat dikerjakan di mana Rasulullah SAW menyerahkan kepada Saidina Abu Bakar

${ }^{121}$ QS. al-Baqarah [2] : 128 
Ash-Shiddiq untuk memimpin 300 orang umat Islam mengerjakan haji.

\section{Rasulullah SAW mengerjakan haji}

Nabi Muhammad SAW telah menunaikan fardhu haji sekali saja dan umroh 4 kali semasa hayatnya. Haji itu dinamakan Hijjatul Wada/ Hijjatul Balagh/ Hijjatul Islam atau Hijjatuttamam Wal Kamal kerana selepas haji itu tidak berapa lama kemudian beliau pun wafat. Beliau berangkat dari Madinatul Munawwarah pada hari Sabtu, 25 Zulqo'dah tahun 10 Hijrah bersama isteri dan sahabat-sahabatnya bersama kurang lebih 90,000 orang Islam. Setelah menginap satu malam di Zulhulaifah, sekarang dikenali dengan nama Bir Ali, 10 km dari Madinah, esoknya Nabi mengenakan pakaian ihram diikuti seluruh anggota rombongan. Mereka berjalan bersama-sama dengan pakaian putih yang sederhana, perlambang kesederhanaan dan persamaan yang amat jelas.

Dengan seluruh kalbu Muhammad SAW menengadahkan wajahnya kepada Tuhan sembari mengucapkan talbiyah sebagai tanda syukur atas nikmat karunia-Nya diikuti kaum muslimin di belakangnya. Hal ini sebagaimana riwayat hadits berikut: 


\section{عَنْ عَبْدِ اللَّهِ بْنِ عُمَرَ رَضِيَ اللَّهُ عَنْهُمَا أَنَّ تَلْبِيَةَ رَسُولِ اللَّهِ صَلَّى اللَّهُ عَلَّْهِ

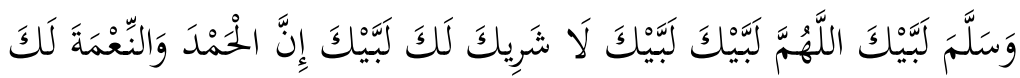

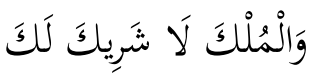

“dari 'Abdullah bin 'Umar radliallahu 'anhua bahwa cara talbiyah Rasulullah shallallahu 'alaihi wasallam adalah: "Labbaikallahumma labbaik. Labbaika laa syariika laka labbaik. Innal hamda wan ni'mata laka wal mulk. Laa syariika lak". ("Aku datang memenuhi panggilanMu ya Allah. Aku datang memenuhi panggilanMu tidak ada sekutu bagiMu. Sesungguhnya segala puji, nikmat milikMU begitu pula kerajaan. Tidak ada sekutu bagiMu"). ${ }^{122}$

Talbiyah tersebut di atas, dilakukan di bawah sengatan matahari gurun, di padang pasir yang tidak dikenal banyak umat, bergerak arus manusia dan kafilah menuju satu titik. Mereka menyambut panggilan Nabi Ibrahim as beberapa abad silam. Tidak ada peristiwa yang membedakan seseorang dengan lainnya. Tidak pula perbedaan ras, bangsa atau warna kulit. Sesungguhnya, inilah pemandangan paling indah tentang asas persamaan bahwa semua makhluk sama di depan

${ }^{122}$ HR. al-Bukhari: 1448. 
Tuhan. Yang membedakan, hanya kadar iman dan takwa seseorang. Mereka memenuhi seruan Nabi untuk saling mengenal, merajut kasih sayang, keikhlasan hati dan semangat ukhuwah islamiah. Dengan penuh kesabaran pula mereka menanti tibanya Haji Akbar, dan rasa rindu bertemu Baitullah, dengan jantung berdegup keras.

Pada tanggal 4 Dzulhijjah rombongan masuk Makkah, selanjutnya Nabi menuju Ka'bah, melakukan thawaf dan mencium Hajar Aswad. Sesudah tawaf, Nabi shalat dua rakaat di Maqam Ibrahim, lalu mencium Hajar Aswad untuk kedua kalinya. Kemudian menghadapkan wajahnya ke arah bukit Shafa, lalu lari-lari kecil antara bukit Shafa dan bukit Marwah. Di situ dimaklumatkan barangsiapa yang tidak membawa hadyu (ternak kurban untuk disembelih) hendaknya mengakhiri ihramnya (tahallul) dan menjadikan ibadah itu sebagai umrah. Awalnya maklumat itu dilaksanakan tanpa sepenuh hati. Nabi marah, sampai-sampai beliau kembali ke kemahnya. "Bagaimana aku tidak marah, aku menyuruh mereka melakukan sesuatu, tapi mereka tidak menaatiku," jawab Nabi atas pertanyaan Aisyah. Namun akhirnya seluruh rombongan menyesali perbuatannya. 
Mereka segera ber-tahallul seperti yang dilakukan Fathimah putri Nabi, dan semua istrinya.

Hari ke-8 Zulhijjah yaitu Hari Tarwiyah, beliau pergi ke Mina bersama rombongannya. Selama satu hari melakukan shalat dan tinggal bersama kaumnya. Malamnya di saat sang fajar menyembul setelah Shalat Subuh, dengan menunggang untanya al-Qashwa', tatkala matahari mulai tampak, beliau menuju Padang Arafah. Dalam perjalanan yang diikuti ribuan muslim yang mengucapkan talbiyah dan bertakbir, Nabi mendengarkan dan membiarkan mereka dalam kekhusyu'an. Pada tanggal 09 Zulhijjah yang jatuh pada hari Jumaat, Rasulullah SAW melakukan wukuf di Arafah. Ketika berada di perut wadi di bilangan Urana, masih di atas unta, Nabi berdiri dan berkhutbah di depan lebih 90.000 orang yang mengelilinginya. Itulah peristiwa bersejarah yang dikenal dengan julukan "Al-Hijjatul Wada" atau "Haji Perpisahan'. Peristiwa yang begitu mengesankan dan indah, serta merupakan khulasha (kesimpulan) ajaran Islam dan sunnahnya yang ia wariskan kepada masyarakat Islam. Khutbah berlangsung di bawah panas matahari yang mampu membakar ubun-ubun, dan didengarkan dengan khidmat. Kepada Umayyah bin Rabi'ah bin Khalaf diminta mengulang 
keras setiap kalimat yang beliau sampaikan, agar didengar di tempat yang jauh. Sore harinya, rombongan Rasulullah SAW bergerak ke arah Muzdalifah untuk bermalam di sana. Menjelang fajar, rombongan menuju ke Mina untuk melakukan pelemparan jumroh kubro (Aqabah), menyembelih ternak kurban. Kemudian menuju Baitullah untuk melaksanakan thawaf Ifadha' dan kembali lagi ke Mina untuk melanjutkan pelemparan jumroh.

Rasulullah SAW telah menyempurnakan semua rukun dan wajib haji hingga tanggal 13 Zulhijjah. Dan pada tanggal 14 Zulhijjah, Rasulullah SAW berangkat meninggalkan Makkah Al-Mukarramah kembali menuju Madinah AlMunawwarah.

\section{Kriteria Haji Mabrur}

Motivasi utama bagi seseorang yang berangkat di jalan Allah menuju tanah suci adalah memperoleh haji mabrur atau yang makbul (diterima). Tidak ada puncak kebahagiaan seseorang yang beribadah, melebihi dari memperoleh Haji Mabrur itu. 


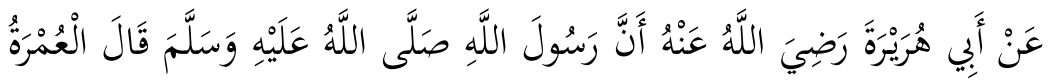

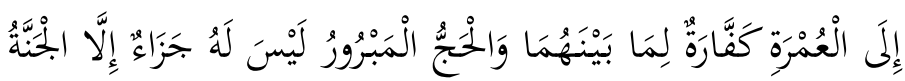

"dari Abu Hurairah radliallahu 'anhu bahwa Nabi shallallahu 'alaihi wasallam berkata: "Umrah demi 'umrah berikutnya menjadi penghapus dosa antara keduanya dan haji mabrur tidak ada balasannya kecuali surga". ${ }^{123}$

Haji mabrur adalah ibadah yang ikhlas karena iman dan taqwa yang dipersembahkan ke hadirat Allah semurnimurninya, khalis dan bersih dari unsur-unsur pengaruh duniawi. Haji mabrur tentu saja bukan haji turis, haji bisnis atau haji politik dan kebanggaan. Ajaran Islam dalam semua aspeknya memiliki hikmah dan tujuan tertentu. Hikmah dan tujuan ini diistilahkan oleh para ulama dengan maqashid syari'ah, yaitu berbagai maslahat yang bisa diraih seorang hamba, baik di dunia maupun di akhirat. Adapun kriteria haji mabrur di antaranya adalah:

a. Harta yang dipakai untuk haji adalah harta yang halal. Dalam hal ini, Allah tidak menerima kecuali yang halal, sebagaimana ditegaskan oleh sabda Nabi SAW:

${ }^{123}$ HR. al-Bukhari: 1650. 


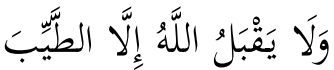

"Dan Allah tidak menerima kecuali yang baik saja". ${ }^{24}$

b. Amalan-amalannya dilakukan dengan ikhlas dan baik, sesuai dengan tuntunan Nabi shallalahu 'alaihi wa sallam.

c. Hajinya dipenuhi dengan banyak amalan baik. Seperti dzikir, shalat di Masjidil Haram, shalat pada waktunya, dan membantu teman seperjalanan. Ibnu Rajab berkata, "Maka haji mabrur adalah yang terkumpul di dalamnya amalan-amalan baik, plus menghindari perbuatanperbuatan dosa.

d. Tidak berbuat maksiat selama ihram. Diantaranya yang dilarang selama haji adalah rafats, fusuq dan jidal. Allah berfirman:

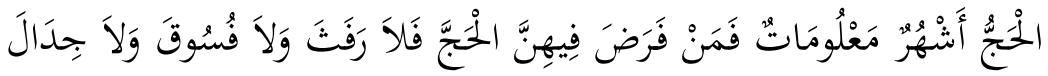

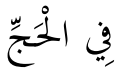

"(Musim) haji adalah beberapa bulan yang diketahui, barang siapa yang menetapkan niatnya dalam bulanbulan itu untuk mengerjakan haji, maka tidak boleh

${ }^{124}$ HR. al-Bukhari: 1321. 
rafats, fusuq dan berbantah-bantahan selama mengerjakan haji." 125

Hal ini juga dikuatkan dengan riwayat hadits berikut:

$$
\begin{aligned}
& \text { عَنْ أَبِي هُرَيْرَة قَالَ قَالَ رَسُولُ اللَّهِ صَلَّى اللَّهُ عَلَيْهِه وَسَلَّمَ مَنْ حَجَّ هَذَا }
\end{aligned}
$$

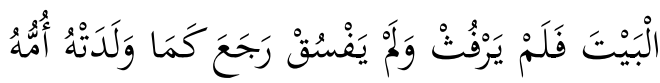

"dari Abu Hurairah, ia berkata; Rasulullah shallallahu 'alaihi wasallam bersabda: "Barang siapa yang melakukan haji ke Ka'bah ini, lantas tidak berkata-kata kotor serta tidak melakukan tindakan kefasikan, ia kembali seperti dilahirkan ibunya." 126

Rafats adalah semua bentuk kekejian dan perkara yang tidak berguna. Termasuk di dalamnya bersenggama, bercumbu atau membicarakannya, meskipun dengan pasangan sendiri selama ihram. Fusuq adalah keluar dari ketaatan kepada Allah, apapun bentuknya. Dengan kata lain, segala bentuk maksiat adalah fusuq yang dimaksudkan dalam hadits di atas. Jidal adalah berbantahbantahan secara berlebihan.

${ }^{125}$ QS. al-Baqarah [2]: 197.

${ }^{126}$ HR. Nasai: 2580. 
e. Kebaikan dan amal sholehnya meningkat setelah selesai melaksanakan ibadah haji dan tiba di tanah air.

Orang yang hajinya mabrur menjadikan ibadah haji sebagai titik tolak untuk membuka lembaran baru dalam menggapai ridha Allah Ta'ala. Ia akan semakin mendekat ke akhirat dan menjauhi dunia. Al-Hasan al-Bashri mengatakan, "Haji mabrur adalah pulang dalam keadaan zuhud terhadap dunia dan mencintai akhirat." Ia juga mengatakan, "Tandanya adalah meninggalkan perbuatan-perbuatan buruk yang dilakukan sebelum haji."

Ibnu Hajar al-Haitami ${ }^{127}$ mengatakan, "Dikatakan bahwa tanda diterimanya haji adalah meninggalkan maksiat yang dahulu dilakukan, mengganti teman-teman yang buruk menjadi teman-teman yang baik, dan mengganti majlis kelalaian menjadi majlis dzikir dan kesadaran."

Sayyid Sabiq mengemukakan, bahwa ciri haji mabrur itu adalah kesediaan memberikan harta kepada yang membutuhkan, dan semakin memiliki kemampuan untuk mengendalikan segala ucapan dan tindakan. ${ }^{128}$

${ }^{127}$ Ibnu Hajar al-Haitami, al-Maktabah asy-Syamilah.

${ }^{128}$ Sayyid Sabiq, Fiqih Sunnah, jilid 5, (Jakarta, Pena Pundi Aksara, 2006), h. 21. 
Dengan demikian, dapat dipahami kriteria haji mabrur, yakni haji yang membuahkan tingkah laku sosial yang bermakna bagi dirinya dan lingkungannya. Hal ini berarti bahwa orang yang menjalankan hajji dalam kesehariannya adalah orang yang jujur, tidak menipu, tidak korupsi, tidak menahan hak orang lain; dan tidak memiliki tanggung jawab sosial yang tinggi terhadap lingkungannya. Tanpa buah yang baik, maka ibadah dapat dikatakan musprah, atau tidak mengandung makna apa-apa baik pelakunya maupun lingkungan sosialnya.

\section{Hikmah Haji}

Ibadah haji yang terdiri dari umrah dan haji merupakan titik kulminasi dari proses pencarian kesempurnaan hidup baik secara individu dan sosial. Ibadah umrah adalah gambaran tahapan yang harus ditempuh seseorang untuk mencapai tingkat kesempurnaan diri secara personal sebgai seorang muslim, dan ibadah haji adalah tahapan dan proses yang harus dilakukan oleh umat Islam untuk mencapai kesempurnaan hidup secara berjamaah, umat yang berkualitas, umat terpandang dalam sejarah kemanusiaan. Itulah sebabnya dalam al Quran, perintah haji dan umrah 
diawali dengan kata-kata : " Dan sempurnakanlah ibadah haji dan umrah karena Allah " ${ }^{\prime 29}$.

Tahapan dan proses kesempurnaan hidup yang dapat kita petik dalam proses pelaksanaan haji di Tanah suci. Ibadah haji melalui dua tahapan yaitu umrah dan haji. Umrah adalah ibadah yang dilakukan secara berturut-turut dari Ihram ( ditandai dengan memakai pakaian ihram ), Tawaf berkeliling ka'bah, Sai yaitu berjalan antara bukit safa dan Marwa , dan Tahallul (menggunting rambut). Sedangkan haji dilakukan dengan melaksanakan prosesi Wukuf di Arafah, Mengambil batu di Muzdalifah pada waktu malam hari, Melontar Jumrah di Mina, Thawaf Ifadah, diikuti dengan menyembelih hewan Qurban Banyak orang menyangka bahwa ibadah ini hanya bersifat ritual, padahal al Quran menyuruh kita mencari hikmah dibalik haji dan umrah sehingga dapat dijadikan model hidup yang sempurna sebagaimana dinyatakan dalam al Quran surat al-Hajj ayat 27-28.

Prosesi ibadah umrah dan haji memberikan pelajaran hidup bagi manusia untuk pendidikan, strategi, dan falsafah hidup, sehingga manusia dapat menjadi individu sempurna

${ }^{129}$ QS. al-Baqarah [2] : 187 
(perfect personality). Beberapa hikmah dari perjalanan Haji ini, antara lain : $:^{130}$

a. Menumbuhkan jiwa tauhid yang tinggi.

b. Pembentukan sikap mental dan akhlak yang mulia.

c. Menyatukan umat Islam sedunia menjadi "ummah wahidah" karena kesatuan aqidah dan kesatuan ideologi.

d. Mengajarkan sejarah khususnya sejarah perjuangan Nabi Muhammad saw dan Nabi Ibrahim as.

e. Mendorong manusia untuk mengenal peta planet bumi, mengetahui tentang manusianya dan megerti tentang masyarakatnya.

f. Menjadi Muktamar Akbar umat Islam sedunia sekali setahun untuk membahas dan memecahkan segala problem Islam.

\section{Makna spiritual haji bagi kehidupan sosial.}

Setiap bagian dari rangkaian ibadah haji merupakan perlambang atau simbol yang diyakini punya makna. Haji adalah simbol dari penyerahan tanpa syarat kepada Allah. Ia adalah simbol kesinambungan ummat ini dengan bapaknya, Ibrahim As. Ia juga merupakan simbol persatuan umat Islam

${ }^{130}$ Nasruddin Razak, op.cit hal 217-218. 
tanpa memandang ras, suku, bangsa, warna kulit, jabatan dan sebagainya. Haji merupakan manifestasi prinsip-prinsip Islam, manifestasi ukuwah Islamiyah karena di dalamnya terkandung makna ta'aruf akbar yang terjadi di antara para haji. Haji merupakan manifestasi kesetiaan seluruh kaum muslimin terhadap satu kekuasaan politik.

Haji pada hakekatnya adalah madrasah tempat penggemblengan yang mengantarkan manusia muslim ke derajat yang lebih tinggi. Sebab dengan berhaji seorang muslim harus mampu belajar, berusaha, dan sabar. Ketika haji setiap gerak hidup orientasinya ibadah. Mau tidak mau mereka harus saling bersikap ramah, tolong menolong, mengendalikan nafsu dan emosi.

Sebagaimana dijelaskan Sa'id Hawa, di dalam ibadah haji banyak kemanfaatan baik duniawi maupun ukhrawi. Diantaranya adalah dijadikannya Makkah al Mukarramah sebagai markas bagi kaum muslimin. Mereka yang berdatangan dari berbagai penjuru merasa bersaudara sehingga seakan-akan haji merupakan sutu muktamar Islam yang juga merupakan sarana pendidikan persaudaraan Islam sedunia atas cinta, persatuan dan kerja . 
Di dalam haji setiap tempat dan amalannya mengandung berbagai ibrah dan makna. Arafah adalah tempat berkumpulnya manusia sebelum melaksanakan tawaf rukun. Setelah wukuf di Arafah semua jamaah haji serentak mereka memulai keberangkatan menuju Ka'bah. Kemudian menuju Muzdalifah dalam keadaan bertaubat dan berserah diri. Lalu mereka menuju kek Ka'bah dengan jiwa bersih. Di muzdalifah mereka menuju mina untuk melempar jumrah sebelum thawaf. Mekontar jumlah sebagai pernyataan bahwa musuh Allah adalah musuh mereka. Kemudian mereka berkorban sebagai wujud syukur dihalalkannya binatang ternak kepada mereka. Lalu mereka mencukur rambut sebagai persiapan untuk tahwaf.

Ritual selanjutnya adalah sa'i yaitu lari-lari kecil dari shafa ke marwah sebagaiman pernah dilakukan ibu mereka, Hajar. Keluar dari perjalanan ini manusia menjadi seperti dilahirkan kembali. Selanjutnya mereka kembali ke Mina untuk melempar jumrah sebagai pernyataan permusuhan total terhadap syaithan selamanya.

Dengan demikian, berdasarkan ayat Al-Qur'an dan hadits Nabi Saw. yang sudha diuraikan sebelumnya, memberikan pengertian bahwa ibadah-ibadah mahdhah harus melahirkan 
tingkah laku sosial yang positif. Nilai-nilai sosial ibadah haji misalnya harus terpancarkan dalam tingkah laku sehari-hari oleh pelakunya. Demikian juga zakat dan segala macam perintah Al-Qur'an tidak hanya bersifat vertikal, bukan sekedar ibadah yang dipersembahkan oleh makhluk kepada sang Khaliq (Allah SWT), melainkan di dalam zakat juga terkandung ajaran yang sangat bijak, yaitu memiliki dimensi horizontal (sosial) yang sangat tajam. Ibadah haji juga merupakan ibadah yang mengangkat solidaritas sosial, bahkan secara tegas dan jelas, solidaritas ekonomi. Kerjasama dan harmonisasi antar ummat Islam di muka bumi ini merupakan salah satu dari tujuan dan hikmah ibadah haji.

Seluruh rangkaian ibadah dalam Islam mengandung ajaran moral yang wajib dihayati oleh setiap pelakunya. Zakat, puasa, dan hajji kesemuanya mengandung ajaran moral yang harus diejawantahkan dalam tingkah laku sehari-hari. Intinya, bahwa kita beribadah adalah untuk kebaikan kita dan lingkungan di dunia ini. Kebaikan di akhirat adalah akibat dari kebaikan di dunia ini. 


\section{Rangkuman}

1. Haji diwajibkan atas orang yang kuasa satu kali seumur hidupnya. Ketentuan ini berdasarkan Firman Allah dalam Q.S. Ali Imran: 97

2. Sejarah Haji. Haji pertama kali disyariatkan oleh Allah pada masa Nabi lbrahim a.s. dan ia adalah Nabi yang dipercaya oleh Allah untuk membangun Ka'bah bersama dengan anaknya Ismail di Mekah. Allah menggambarkan Ka'bah sebagai berikut: "Dan ingatlah ketika Kami memberikan tempat kepada Ibrahim di tempat Baitullah (dengan mengatakan): janganlah kamu memperserikatkan sesuatupun dengan Aku dan sucikanlah rumah-Ku ini bagi orang-orang yang thawaf, dan orang-orang yang beribadat mereka yang ruku' dan sujud." (Al-Hajj :26)

Setelah membangun Ka'bah, Nabi Ibrahim datang ke Mekah untuk melakukan ibadah haji setiap tahun, dan setelah kematiannya, praktik ini dilanjutkan oleh anaknya. Namun, secara bertahap dengan berlalunya waktu, baik bentuk dan tujuan ritual haji berubah sebagai penyembahan berhala yang tersebar di seluruh Arabia, Ka'bah kehilangan kemurnian dan berhala ditempatkan di dalamnya. Dindingnya penuh dengan 
puisi dan lukisan, dan akhirnya lebih dari 360 berhala ditempatkan di sekitar Ka'bah.

Selama periode haji itu sendiri, suasana di sekitar rumah suci (Ka'bah) layaknya seperti sirkus. Laki-laki dan perempuan mengelilingi Ka'bah dengan telanjang, dengan alasan bahwa mereka harus menampilkan diri di hadapan Allah dalam kondisi yang sama seperti mereka lahir. Doa mereka menjadi bebas tak lagi tulus mengingat Allah, malah berubah menjadi serangkaian tepuk tangan, bersiul dan meniup tanduk, bahkan kalimat talbiah telah diselewengkan oleh mereka dengan tambahan-tambahan. Bahkan darah binatang yang dikurbankan dituangkan ke dinding Ka'bah dan dagingnya digantung di tiang sekitar Ka'bah, dengan keyakinan bahwa Allah menuntut daging dan darah hewan-hewan ini. Mengenai hal ini Allah SWT mengingatkan dengan firman-Nya: "Daging-daging unta dan darahnya itu sekali-kali tidak dapat mencapai (keridhaan) Allah, tetapi ketaqwaan dari kamulah yang dapat mencapainya." (Al-Hajj: 37)

Selama dua puluh tiga tahun, Nabi Muhammad menyebarkan pesan-pesan tauhid yang sama bahwa 
Nabi Ibrahim dan semua Nabi pendahulunya datang dengan membawa dan mendirikan hukum Allah dimuka bumi. Nabi tidak hanya membersihkan Ka'bah dari segala kotoran, tapi juga mengembalikan semua ibadah haji yang dituntunkan oleh Allah di masa Nabi Ibrahim.

Terdapat perintah khusus dalam Al-Quran diturunkan dalam rangka menghilangkan semua upacara palsu yang telah merajalela di masa praIslam. Semua tindakan tidak senonoh dan memalukan itu sangat dilarang dalam pernyataan Allah SWT: "Musim haji adalah beberapa bulan yang dimaklumi, barangsiapa yang menetapkan niatnya dalam bulan itu akan mengerjakan haji, maka tidak boleh rafats (mengeluarkan perkataan yang menimbulkan birahi yang tidak senonoh atau bersetubuh), berbuat fasik dan berbantah-bantahan di dalam masa mengerjakan haji." (Al-Baqarah: 197).

3. Kriteria Haji mabrur, diantaranya: (a) Segala amalan ibadah haji dilakukan dan berdasarkan atas keikhlasan mendapatkan keridhoan Allah Ta'ala dan juga dilaksanakan sesuai dengan tuntunan syariat Islam; (b) Harta yang digunakan dalam melaksanakan haji 
tersebut adalah dari hasil harta yang halal; (c) melaksanakan serangkaian ibadah haji yang telah dituntunkan dan ditambah serta dipenuhi dengan amalan-amalan ibadah lainnya yang menyertainya seperti halnya memperbanyak dzikir di Masjidil Haram, memperbanyak sedekah di kala haji dan berkata-kata yang baik; (d) Tidak melakukan perbuatan maksiat khususnya dalam melaksanakan ihram; dan (e) Kebaikan dan amal sholehnya meningkat setelah selesai melaksanakan ibadah haji dan tiba di tanah air.

4. Hikmah haji, diantaranya: (a) Menumbuhkan jiwa tauhid yang tinggi; (b) Pembentukan sikap mental dan akhlak yang mulia; (c) Menyatukan umat Islam sedunia menjadi "ummah wahidah" karena kesatuan aqidah dan kesatuan ideology; (d) Mengajarkan sejarah khususnya sejarah perjuangan Nabi Muhammad saw dan Nabi Ibrahim as; (e) Mendorong manusia untuk mengenal peta planet bumi, mengetahui tentang manusianya dan megerti tentang masyarakatnya; dan (f) Menjadi Muktamar Akbar umat Islam sedunia sekali setahun untuk membahas dan memecahkan segala problem Islam. 
5. Makna spiritual ibadah haji, diantaranya: (a) Ihram merupakan kesucian diri dengan mengontrol keinginan dan nafsu. (b) Thawaf adalah hidup dalam lingkaran ibadah. (c) Sai lambing meningkatkan etos kerja sebagai khalifah; (d) Tahalul pelajaran tentang pelayanan sosial secara individual; (e) Wukuf sebagai upaya menggalang potensi dan jaringan, menyusun langkah dan program umat, mengatur strategi, menghadapi tantangan dan masa depan; Muzdalifah merupakan persiapan menghadapi ancaman dan tantangan; (g) Melontar Jumrah di Mina adalah semangat perjuangan; dan (h) Menyembelih Qurban: sebagai bentuk lambang pengorbanan kepada Allah SWT.

\section{Latihan/Tugas/Eksperimen}

Mahasiswa dilatih manasik haji dengan melakukan amalamalan haji (tata cara pelaksanaan ibadah haji), yaitu diantaranya: (1) Ihram; (2) Mabit; (3) Wukuf; (4) Melempar Jamrah Aqabah; (5) Tahallul; (6) Thawaf Ifadah; (7) Sa'i; (8) Melempar tiga Jamrah yaitu Jamrah 
Shughra, Jamrah Wustha, Jamrah Qubra/Aqabah; dan (9) Thawaf Wada'.

\section{DAFTAR PUSTAKA}

Bek, Muhammad al-Khudri, Tarikh Tasyri' Al-Islami, alih bahasa Mhd. Zuhri. Indonesia: Darul Ikhya, t.t.

Compact Disc (CD), al-Maktabah asy-Syamilah.

Ensiklopedi Hadits 9 Imam.

Departemen Agama RI, Al-Qur'an dan Tafsirnya, Jakarta: Departemen Agama RI, 2010.

Hassan, Abdul Qadir, Kata Berjawab: Solusi untuk Berbagai Permasalahan Syariah, Surabaya: Pustaka Progressif, 2006.

Qardhawi, Yusuf, Fiqh Prioritas, cet. ke-2. Jakarta: Gema Insani Press, 1997.

Razak, Nasruddin, Dienul Islam, Bandung, PT. Al Ma'arif, 1996.

Sabiq, Sayyid, Fiqih Sunnah, jilid 5, Jakarta, Pena Pundi Aksara, 2006. 


\section{BAB V}

\section{IBADAH MALIAH DAN MAKNA SPIRITUALNYA DALAM KEHIDUPAN SEHARI-HARI}

\section{A. Pendahuluan}

Islam memiliki dimensi yang sangat luas dalam memberikan perhatian bagi kehidupan manusia, termasuk dalam pemeliharaan 'māliyah (harta benda). Dalam upaya pemeliharaan harta benda, Islam menempatkannya secara eksplisit ke dalam salah satu dari lima unsur pokok yang harus dipelihara, yaitu: Hifzh al-Mal, yang terangkum dalam maqashid syari'ah. Di mana keempat unsur pokok yang lain adalah: agama (Hifzh al-Din), jiwa (Hifzh al-Nafs), akal (Hifzh al-'Aql), keturunan (Hifzh al-Nasl). ${ }^{131}$

Diskursus tentang 'māliyah (harta benda), Islam tidak mendikotomikan dengan memisahkannya dari kapling agama, namun tetap menjadikan 'māliyah sebagai bagian yang tidak terpisahkan dari upaya merealisasikan ajaran agama dan bahkan maliyah ditakdirkan untuk memenuhi kebutuhan manusia. ${ }^{132}$ Oleh karenanya, seseorang dalam mendapatkan 'māliyah diorientasikan untuk mendukung terealisasinya

${ }^{131}$ Fathurrahman Djamil, Filsafat Hukum Islam, (Jakarta: Logos Wacana Ilmu, 1999), h. 125.

${ }^{132}$ QS. al-Hijr [15]: 20. 
perintah agama dalam kehidupan, terutama memberikan kamaslahatan kepada orang lain, antara lain dengan berinfak, bershadaqah, dan menyatuni kaum dhu'afa.

Berpijak dari kelima unsur pokok yang harus dipelihara di atas, dan terkait tentang hifzh al-Mal, menjadikan harta benda sebagai wahana kehidupan di dunia ini untuk mengabdikan dirinya kepada Allah. Ibadah dengan harta dalam bahasan bab kelima ini disebut 'ibādah māliyah. Oleh karena itu, orientasi capaian pembelajaran pada bab ini adalah mahasiswa dapat memahami: (1) pengertian 'ibādah māliyah; (2) macam-macam 'ibādah māliyah (zakat, infaq dan shadaqah); (3) urgensi 'ibādah māliyah; (4) hikmah menjalankan 'ibādah māliyah; dan (5) makna spiritual 'ibādah māliyah dalam kehidupan sehari-hari.

\section{B. Penyajian Materi}

\section{Hakikat 'ibādah māliyah}

Sebelum membahas sub tema ini dan juga memerlukan kerangka berfikir untuk memahami hakikat 'ibādah māliyah, maka tulisan ini mengkaji terlebih dahulu tentang hakikat harta, dan sikap terhadap harta. Kemudian diakhir dengan penjelaskan tentang pengertian 'ibādah māliyah. 


\section{a. Hakikat harta}

Harta merupakan amanah dan karunia Allah yang didapat bukan karena kehebatan seseorang, tetapi karena berkah dan karunia dari Allah. Oleh karena itu, keberadaan harta bukan untuk kesenangan pribadi, akan tetapi digunakan untuk memberikan kemaslahatan kepada orang lain. Hal ini digambarkan pada firman Allah berikut:

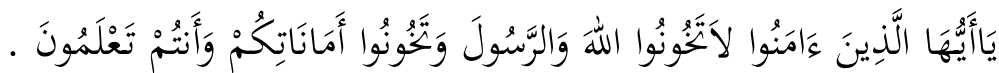

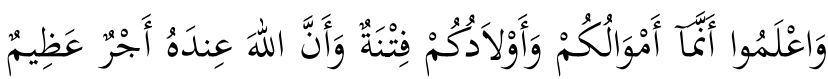

"Hai orang-orang beriman, janganlah kamu, mengkhianati Allah dan Rasul (Muhammad) dan juga janganlah kamu mengkhianati amanat-amanat yang dipercayakan kepadamu, sedang kamu mengetahui”. "Dan ketahuilah, bahwa hartamu dan anak-anakmu itu hanya sebagai cobaan dan sesungguhnya di sisi Allahlah pahala yang besar". 133

Ayat di atas, juga diperkuat oleh riwayat hadits Nabi SAW berikut:

عَنْ أَبْي هُرَيْرَة أَنَّْ رَسُولَ اللَّهِ صَلَّى اللَّهُ عَلَيْهِه وَسَاَّمَ قَالَ يَقُولُ الْعَبُُْ مَالِي

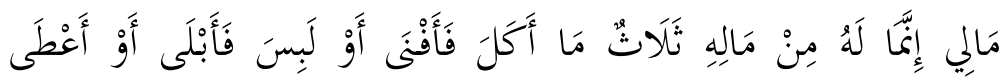
فَاقْتَنَى وَمَا سِوَى ذَلِكَ فَهُهُ ذَاهِبُْ وَتَارِكُهُ لِلنَّاسِ

${ }^{133}$ QS. al-Anfaal [8]: 27- 28. 
"Dari Abu Hurairah Rasulullah Shallallahu 'alaihi wa Salam bersabda: "Manusia berkata, 'Hartaku, hartaku,' sesungguhnya hartanya ada tiga: yang ia makan lalu ia habiskan, yang ia kenakan lalu ia usangkan atau yang ia berikan (sedekahkan) lalu ia miliki, selain itu akan lenyap dan akan ia tinggalkan untuk manusia'." 134

Berdasar ayat al-Qu'an dan al-Hadits di atas, dapat dipahami pertama, bahwa harta yang sesungguhnya adalah apa yang manusia infakkan, dan shadaqahkan di jalan Allah. Kedua, hakikat pemilik segala sesuatu termasuk harta benda, baik di bumi maupun di langit adalah hanyalah Allah SWT. Hal ini menunjukkan, bahwa terkait harta, manusia hanya mendapatkan titipan untuk mengelola, memanfaatkan, dan menjaganya sebagaimana yang memberi amanah tersebut, yakni Allah SWT. Dengan demikian, kepemilikan harta dipahami sebagai amanah. Menurut Dawam Rahardjo, kata amanah mempunyai akar yang sama dengan kata iman (percaya) dan amana yang berarti memberikan, memiliki kepercayaan, atau trust, dan juga berarti aman (dalam pengertian Indonesia). ${ }^{135}$

${ }^{134}$ HR. Muslim: 5259

135 M. Dawam Rahardjo, Islam dan Transformasi Sosial-Ekonomi, (Yogyakarta: Lembaga Studi Agama dan Filsafat, 1999), h. 331-332. 
Dorongan manusia dalam harta, sebagai wujud fitrah manusia yang memiliki kecenderungan menyukai harta tidak sekedar untuk memenuhi kebutuhan, namun bisa jadi akan terperdaya sehingga lupa dengan amanahnya. Kecenderungan terhadap kepemilikan harta begitu kuat, sehingga dalam beberapa ayat ${ }^{136}$ dan riwayat hadits dijelaskan sebagai berikut:

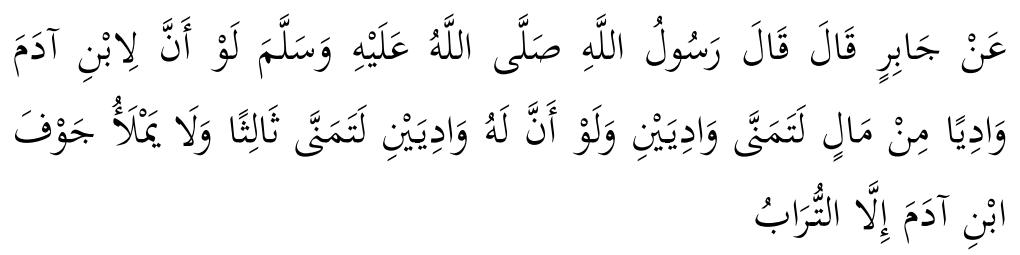

"Dari Jabir berkata; Rasulullah shallallahu 'alaihi wasallam bersabda: "Seandainya anak Adam memiliki satu lembah harta niscaya dia akan menginginkan dua lembah. seandainya dia memiliki dua lembah harta niscaya dia akan menginginkan yang ketiga, dan tidak akan pernah penuh perut anak Adam kecuali dengan tanah". ${ }^{137}$

Al-Qur'an surah at-Takatsur ayat 1 menjelaskan bahwa manusia kecenderungan menyibukkan diri dengan bermegah-megahan terhadap harta, anak, pengikut, kemuliaan, dan seumpamanya, sehingga melalaikannya

${ }^{136}$ QS. at-Takatsur [102]: 1.

${ }^{137}$ HR. Ahmad: 14130. 
dari kegiatan beramal dan ketaatan kepada Allah SWT. Seseorang berusaha memiliki lebih banyak dari yang lain (harta atau kedudukan) dengan tujuan semata-mata untuk mencapai ketinggian dan kebanggaan, bukan digunakan untuk ketaatan dan kebaikan. Muhasabah ayat tersebut, yang dikoreksi bukan masalah bermegahnya, tapi kemegahan yang membuat lupa pada nilai-nilai kebenaran, melupakan pada hak Allah, hak fakir miskin, hari akhirat dan melupakan akan ajaran-ajaran Allah SWT.

Dalam persoalan kesenangan memperoleh harta, Islam secara tegas menyatakan:

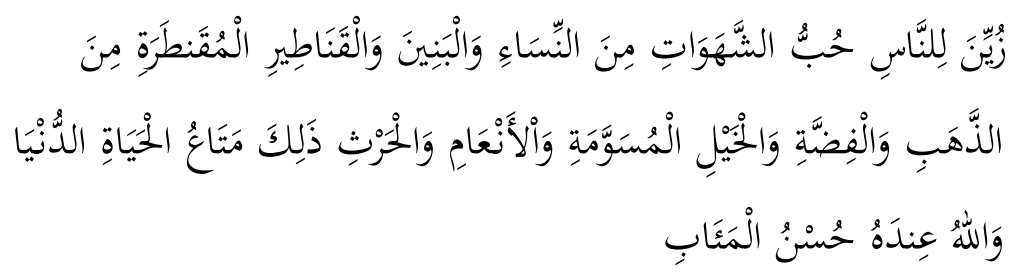

"Dijadikan indah pada (pandangan) manusia kecintaan kepada apa-apa yang diingini, yaitu: wanita-wanita, anak-anak, harta yang banyak dari jenis emas, perak, kuda pilihan, binatang-binatang ternak dan sawah ladang. Itulah kesenangan hidup di dunia; dan di sisi Allah-lah tempat kembali yang baik (surga)."138

${ }^{138}$ QS. Ali Imran [3]:14. 
Ayat di atas, menjelaskan bahwa harta memiliki daya tarik agar seseorang bisa kaya, memiliki materi yang berlimpah, kemewahan, serta dengan mudah memenuhi kebutuhannya. Menurut Quraish Shihab, menyatakan: "daya tarik harta tersebut sangat menggiurkan dan menyilaukan mata bisa menyebabkan manusia lupa akan hakikat dirinya sebagai hamba Allah dan khalifah di muka bumi". 139

\section{b. Sikap terhadap harta}

Allah sendiri dalam firman-Nya menegaskan, bahwa harta adalah cobaan, yang mengharuskan manusia berhatihati dalam menggunakan cara untuk memperoleh harta dan mendayagunakannya. Jika yang dilakukan salah bisa jadi harta tersebut akan menyebabkan manusia tersebut menemui kesukaran, bukan hanya kesukaran di akhirat kelak ketika dimintai pertanggung jawaban, melainkan termasuk di dunia.

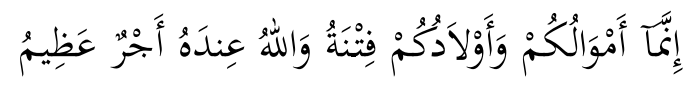

${ }^{139}$ Quraish Shihab, Wawasan al-Qur'an, (Bandung: Mizan, 2003), h. 405. 
"Sesungguhnya hartamu dan anak-anakmu hanyalah cobaan (bagimu); dan di sisi Allahlah pahala yang besar". ${ }^{140}$

Dalam firman Allah yang lain ditegaskan bahwa harta adalah perhiasan dunia,

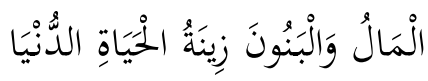

"Harta dan anak-anak adalah perhiasan kehidupan dunia". ${ }^{141}$

Dengan demikian, makna perhiasan bukanlah unsur pokok, melainkan hanya bersifat pelengkap (sekunder) dan penunjang bagi terpenuhinya unsur pokok. Barangkali dengan harta melimpah manusia akan tampak lebih megah dan berwibawa. Sebaliknya, dengan harta yang sedikit merasa inferior saat berhadapan dengan orang-orang yang kaya, karena takut tidak diperhitungkan. Kemegahan dengan harta yang melimpah hanya bisa dinikmati di dunia, yang berarti pada saat manusia mati, harta tersebut tidak bisa mengiringinya. Oleh karena itu, sikap terpenting

${ }^{140}$ QS. at-Taghabun: 15.
${ }^{141}$ QS. al-Kahfi: 46. 
terhadap harta adalah menjaga diri dari harta yang dimiliki dan diyakini sebagai karunia yang diberikan Allah dan sebagai ujian bagi manusia untuk mengujinya apakah ia menjadi hamba yang bersyukur atau seorang hamba yang kufur kepada Allah.

\section{c. Pengertian 'ibādah māliyah}

Ibādah māliyah adalah ibadah yang dilakukan dengan menggunakan sarana harta benda sebagai bentu ta'abbudi kepada Allah. Dengan demikian, 'ibādah māliyah (ibadah harta) pada prinsipnya adalah menggunakan harta benda sebagai instrumen ibadah dan ta'abbudi kepada Allah.

\section{Macam-macam 'ibādah māliyah}

Instrumen 'ibādah māliyah dalam Islam di antaranya berupa: zakat, infaq, shadaqah, fidyah, kifarat, qurban atau udhiyyah, aqiqah, al-hadyu, dan dam. Ibadah māliyah dalam sub bahasan ini dibatasi pada 3 macam 'ibadah māliyah (ibadah harta) sebagai sarana ibadah kepada Allah, yaitu zakat, infaq, dan shadaqah. 


\section{a. Zakat}

Zakat ditinjau secara etimologi (bahasa) berarti suci, baik, berkah, tumbuh, dan berkembang. ${ }^{142}$ Berdasar pengertian zakat secara bahasa tersebut, Amiruddin Inoed, memahami, bahwa zakat sebagai salah satu nilai instrumental yang disyariatkan agama kepada manusia untuk membersihkan dan mensucikan manusia dari kotoran kikir dan dosa, serta menyuburkan pahala melalui pengeluaran sebagian dari nilai harta pribadi untuk kaum yang memerlukan. ${ }^{143}$

Makna zakat secara etimologi yang berarti mensucikan dari kotoran diperjelaskan dalam al-Qur'an. ${ }^{144}$ Sedangkan makna zakat yang berarti membersihkan dan mensucikan juga ditelusuri terdapat dalam firman Allah berikut:

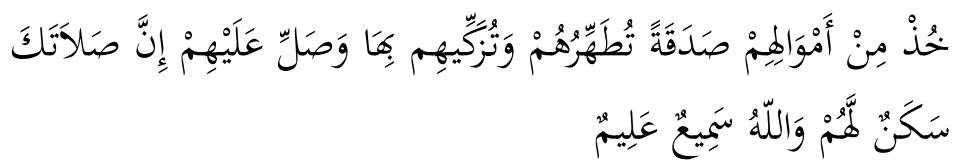

"Ambillah zakat dari sebagian harta mereka, dengan zakat itu kamu membersihkan dan mensucikan mereka

${ }^{142}$ Didin Hafidhuddin, Panduan Praktis tentang Zakat, Infaq, dan Shadaqah, (Jakarta : Gema Insani, 1998), h. 13.

${ }^{143}$ Amiruddin Inoed, dkk. Anatomi Fiqh Zakat : Potret \&

Pemahaman Badan Amil Zakat Sumatera Selatan. (Yogyakarta : Pustaka Pelajar, 2005), h. 8.

${ }^{144}$ QS. asy-Syam [91]: 9 dan QS. al-A'la [87]: 14. 
dan mendoalah untuk mereka. Sesungguhnya doa kamu itu (menjadi) ketenteraman jiwa bagi mereka, dan Allah Maha mendengar lagi Maha mengetahui". ${ }^{145}$

Secara terminologi syariat (istilah), yaitu zakat adalah sejumlah harta tertentu yang telah mencapai syarat tertentu yang diwajibkan oleh Allah SWT untuk dikeluarkan dan diberikan kepada yang berhak menerimanya dengan persyaratan tertentu pula. ${ }^{146}$ Yusuf Qardhawi menambahkan bahwa yang dimaksudkan jumlah yang dikeluarkan dari kekayaan itu disebut zakat karena yang dikeluarkan itu menambah banyak, membuat lebih berarti, dan melindungi kekayaan itu dari kebinasaan. ${ }^{147}$

Berdasarkan pengertian zakat di atas, dapat dipahami bahwa esensi zakat merupakan mengeluarkan dan memberikan sejumlah harta yang wajib dizakati oleh orang yang wajib membayar zakat (muzakki) sesuai dengan ketentuan syariah untuk diberikan kepada mereka yang

${ }^{145}$ QS. at-Taubah [9]: 103.

${ }^{146}$ Didin Hafidhuddin, Panduan Praktis tentang Zakat, Infaq, dan Shadaqah, (Jakarta : Gema Insani, 1998), h. 13.

${ }^{147}$ Yusuf Qardhawi, Hukum Zakat, alih bahasa: Didin Hafidhuddin dan Hasanuddin, (Jakarta : Pustaka Litera Antar Nusa, 1993), h. 19. 
berhak menerimanya (mustahiq) sebagaimana yang telah ditentukan oleh agama. ${ }^{148}$

\section{b. Infaq}

Infaq berasal dari bahasa Arab, yaitu: - -

أَنْفَقَ, yang berarti mengeluarkan atau membelanjakan

harta. Munhanif Herry, menjelaskan bahwa yang dimaksud makna infaq tersebut adalah membelanjakan atau mengeluarkannya untuk kebaikan, donasi, atau sesuatu yang bersifat untuk keperluan sendiri, atau keinginan dan kebutuhan yang bersifat konsumtif." ${ }^{149}$ Yusuf Qardhawi juga mengartikan infaq adalah mengeluarkan sesuatu (harta) oleh setiap orang yang beriman, baik yang berpenghasilan tinggi maupun rendah untuk kepentingan sesuatu. ${ }^{150}$ Hal ini didasarkan pada firman Allah berikut:

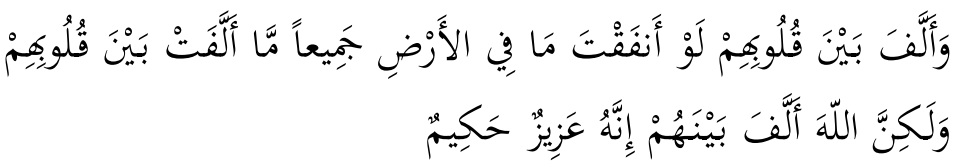

"Dan yang mempersatukan hati mereka (orang-orang yang beriman). walaupun kamu membelanjakan

${ }^{148}$ Q.S. at-Taubah [9]: 60

${ }^{149}$ Munhanif Herry, Tuntunan Praktis Zakat dan Permasalahannya (Cibubur: Variapop, 2012), h. 14.

${ }^{150}$ Yusuf Qardhawi, Hukum Zakat, alih bahasa: Didin Hafidhuddin dan Hasanuddin, (Jakarta : Pustaka Litera Antar Nusa, 1993), h. 14. 
semua (kekayaan) yang berada di bumi, niscaya kamu tidak dapat mempersatukan hati mereka, akan tetapi Allah telah mempersatukan hati mereka. Sesungguhnya Dia Maha gagah lagi Maha Bijaksana".

Makna infaq berarti mengeluarkan sesuatu (harta) oleh setiap orang yang beriman, baik yang berpenghasilan tinggi maupun rendah juga diperjelaskan dalam firman Allah berikut:

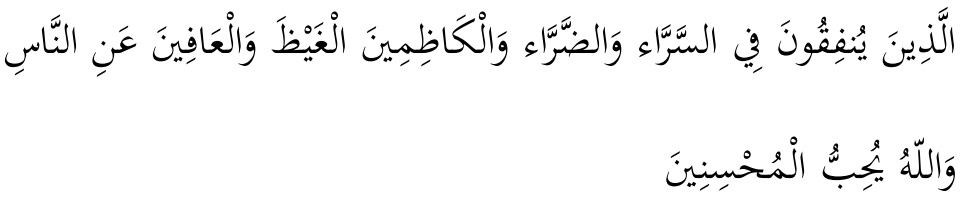

"(yaitu) orang-orang yang menafkahkan (hartanya), baik di waktu lapang maupun sempit, dan orang-orang yang menahan amarahnya dan mema'afkan (kesalahan) orang. Allah menyukai orang-orang yang berbuat kebajikan". 152

Kedua ayat di atas, dapat dipahami bahwa infaq adalah mengeluarkan sebagian dari harta atau pendapatan untuk satu kepentingan yang diperintahkan ajaran Islam. Infaq dikeluarkan oleh setiap orang yang beriman, baik

${ }^{151}$ QS. al-'Anfaal [8]: 63.

152 QS. Ali Imran [3]: 134. 
orang yang memiliki penghasilan tinggi maupun rendah, dalam kondisi lapang maupun sempit. Orang yang menerima tidak dibatasi atau dikhususkan sebagaimana ketentuan orang yang menerima zakat. Oleh karenanya, penerima infaq mencakup kepada semua orang, baik kepada kedua orang tua, anak yatim maupun yang lainnya. 153

Infaq dapat digunakan untuk mengeluarkan sebagian hartanya untuk kemaslahatan umum, di samping kepada siapa saja terutama yang disebutkan dalam ayat tersebut di atas secara berurutan. Orang-orang yang menerima infaq secara berurutan dimulai ibu-bapak, kaum kerabat, anakanak yatim, orang-orang miskin dan orang-orang yang sedang dalam perjalanan. Hal ini menunjukkan prioritas dalam berinfaq. Maknanya, infaq kepada orang tua lebih diprioritaskan sebelum yang lainnya, kemudian kepada yang lainnya. ${ }^{154}$

\section{c. Shadaqah}

Shadaqah berasal dari bahasa Arab: صدقة (benar). Hal ini berarti, orang yang suka bershadaqah merupakan orang

${ }^{153}$ QS. al-Baqarah [2]: 215.

${ }^{154}$ QS. al-Baqarah [2]: 177 dan QS. an-Nisaa' [4]: 36. 
yang benar pengakuan imannya. Secara terminologi syariat, Didin Hafidhuddin menyatakan bahwa shadaqah memiliki kesamaan makna dengan pengertian infaq, termasuk juga hukum dan ketentuan-ketentuannya. Hal ini dikarenakan, makna shadaqah juga seringkali dipergunakan dalam al-Qurean, tetapi maksud sesungguhnya adalah zakat. ${ }^{155}$ Perbedaannya adalah infaq berkaitan dengan materi (harta benda, barang berguna, dan sejenisnya), sementara shadaqah memiliki arti lebih luas dan umum, yaitu mencakup segala sesuatu, materi dan non materi. ${ }^{156}$ Makna shadaqah tersebut diperkuat oleh hadits riwayat Imam al-Bukhari berikut:

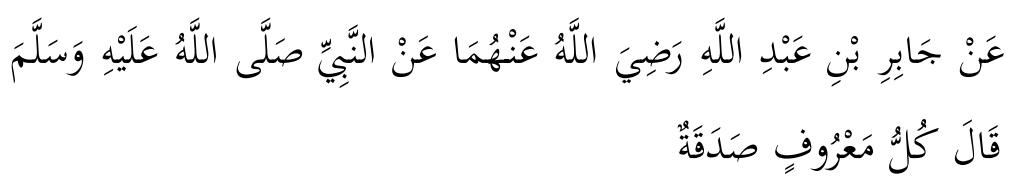

"dari Jabir bin Abdullah radliallahu 'anhuma dari Nabi shallallahu 'alaihi wasallam beliau bersabda: "Setiap perbuatan baik adalah sedekah."157

Dalam hadits al-Bukhari yang lain, juga memberikan penguatan, bahwa Nabi SAW bersabda:

155 Lihat dalam QS. at-Taubah [9]: 60.

${ }^{156}$ Didin Hafidhuddin, Panduan Praktis tentang Zakat, Infaq,

Sedekah, (Jakarta : Gema Insani, 1998), h. 15.

${ }^{157}$ HR. al-Bukhari: 5562 


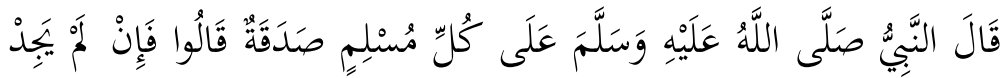

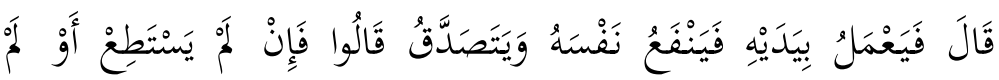

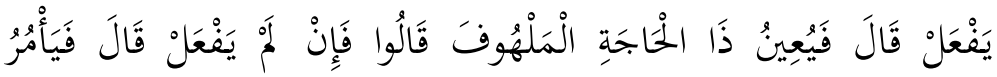

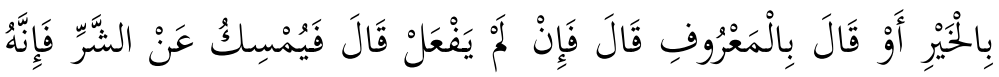 لَلَ صَأَقَةُّة}

"Wajib bagi setiap muslim untuk bersedekah." Para sahabat bertanya; "Bagaimana jika ia tidak mendapatkannya? ' Beliau bersabda: 'Berusaha dengan tangannya, sehingga ia bisa memberi manfaat untuk dirinya dan bersedekah.' Mereka bertanya; 'Bagaimana jika ia tidak bisa melakukannya? 'Beliau bersabda: 'Menolong orang yang sangat memerlukan bantuan.' Mereka bertanya; 'Bagaimana jika ia tidak bisa melakukannya? 'Beliau bersabda: 'Menyuruh untuk melakukan kebaikan atau bersabda; menyuruh melakukan yang ma'ruf' dia berkata; 'Bagaimana jika ia tidak dapat melakukannya? 'Beliau bersabda: 'Menahan diri dari kejahatan, karena itu adalah sedekah baginya. ${ }^{158}$

Selain hadist di atas, ada pula hadist lain yang menjelaskan mengenai jenis-jenis shadaqah, yaitu hadist yang diriwayatkan oleh Imam Muslim:

${ }^{158}$ HR. al-Bukhari: 5563. 


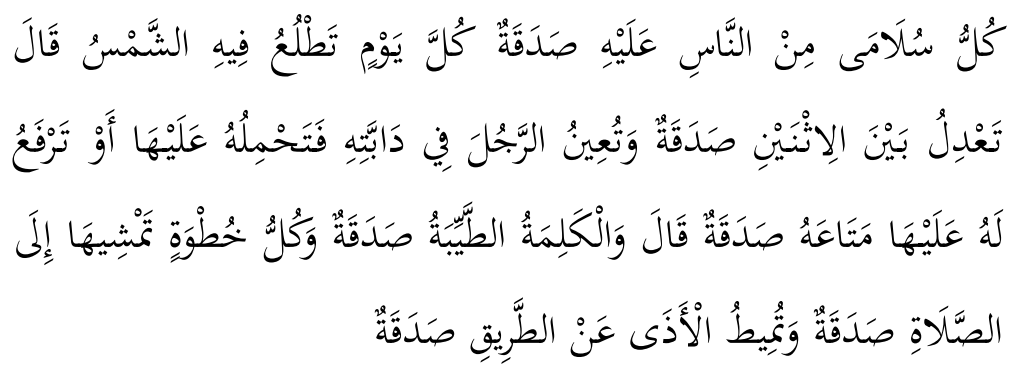

"Setiap anggota tubuh manusia memiliki keharusan sedekah pada setiap harinya. Yaitu seperti mendamaikan dua orang yang berselisih, adalah sedekah. Menolong orang yang naik kendaraan, atau menolong mengangkatkan barangnya $\mathrm{ke}$ atas kendaraan, itu pun termasuk sedekah. Ucapan atau tutur kata yang baik, juga sedekah. Setiap langkah yang Anda ayunkan untuk menunaikan shalat, juga sedekah. Dan menyingkirkan sesuatu yang membahayakan di jalanan umum, adalah sedekah.

Muhammad Taufiq Ridha juga mengartikan bahwa shadaqah adalah suatu pemberian yang diberikan oleh seorang muslim kepada orang lain secara spontan dan sukarela tanpa dibatasi oleh waktu dan jumlah tertentu. Juga berarti suatu pemberian yang diberikan oleh seseorang sebagai kebajikan yang mengharap ridha Allah SWT dan pahala semata. ${ }^{160}$

159 HR. Muslim: 1677.
${ }^{160}$ M. Taufiq Ridha, Perbedaan ZIWAF, (Jakarta: Tabung Wakaf Indonesia, tt), h. 1. 
Sedangkan shadaqah adalah mengeluarkan harta dengan tujuan untuk mendekatkan diri kepada Allah. ArRaghib al-Asfani mendefinisikan shadaqah adalah:

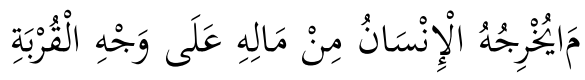

"Harta yang dikeluarkan oleh seseorang untuk mendekatkan diri kepada Allah"161

Dari beberapa uraian tentang ibadah maliyah (zakat, infaq dan shadaqah) di atas, dapat disimpulkan bahwa seseorang yang berzakat, tetapi masih memiliki kelebihan harta, sangat dianjurkan sekali untuk berinfaq atau bershadaqah. Berinfaq adalah ciri utama orang yang bertaqwa, ciri mukmin yang mengharapkan keuntungan abadi di akhirat berupa kebahagiaan di surga.

\section{Urgensi 'ibādah māliyah}

Secara substantif, 'ibādah māliyah berupa zakat, infaq, dan shadaqah adalah bagian dari mekanisme keagamaan yang berintikan semangat pemerataan pendapatan. Dana zakat diambil dari harta orang berkelebihan dan disalurkan kepada orang yang kekurangan. Zakat tidak dimaksudkan

${ }^{161}$ Munhanif Herry, Tuntunan Praktis Zakat dan Permasalahanny, (Cibubur: Variapop, 2012), h. 18. 
untuk memiskinkan orang kaya, juga tidak untuk melecehkan jerih payah orang kaya. Hal ini disebabkan karena zakat di ambil dari sebagian kecil hartanya dengan beberapa kriteria tertentu yang wajib dizakati. Oleh karena itu, alokasi dana zakat tidak bisa diberikan secara sembarangan dan hanya dapat disalurkan kepada kelompok masyarakat tertentu.

Demikian juga, infaq dan shadaqah dalam pandangan hukum Islam bersifat tidak wajib, tetapi pranata keagamaan ini merupakan media pemerataan pendapatan bagi umat Islam sangat dianjurkan. Dengan kata lain, fungsi infaq dan shadaqah merupakan media untuk memperbaiki taraf kehidupan.

Urgensi Ibādah māliyah sangat penting bagi kehidupan manusia, yaitu dapat dilihat dari berbagai segi, antara lain:

a. Secara syariat, 'ibādah māliyah sebagai pembuktian ketaatan kepada syariat Allah. Hal ini, dalam ajaran Islam orang yang yang sengaja memisahkan zakat dari shalat dikecam karena menurut syariat urgensi zakat sama dengan urgensi shalat. Rasulullah SAW. bersabda: "Islam terbangun atas lima perkara, yaitu; bersaksi bahwa tidak ada Tuhan yang berhak disembah kecuali 
Allah, mendirikan shalat, membayar zakat, melakukan haji, dan berpuasa Ramadhan." ${ }^{162}$

b. Secara sosial, 'ibādah māliyah berfungsi untuk membangun stabilitas kehidupan sosial dengan mengikis kesenjangan dan menjaga keseimbangan hidup serta menghindari ketidakadilan sosial.

c. Secara pribadi, 'ibādah māliyah berfungsi untuk menumbuhkan kepekaan hati pada sesama manusia. Ibadah maaliyah membersihkan hati dari kotoran kebakhilan, keserakahan, kekejaman dan kezaliman terhadap kaum fakir miskin.

d. Secara perekonomian, 'ibādah māliyah berfungsi untuk mengembangkan pemanfaatan harta, karena harta seseorang akan menjadi bertambah, dan multi manfaatnya, bukan hanya untuk diri sendiri.

\section{Hikmah menjalankan 'ibādah māliyah}

Ibādah māliyah (zakat, infaq, dan shadaqah) membawa berkah baik kepada orang miskin selaku penerima maupun orang kaya atau para agniya, diantaranya adalah:

162 HR. Nasa'i: 4915. 
a. Membersihkan harta dari hak-hak orang lain yang dititipkan oleh Allah kepada orang kaya.

b. Membersihkan hati dari penyakit tamak, rakus, kikir, dan serta penyakit-penyakit hati lainnya. Jadi zakat memiliki satu kekuatan transformatif dalam menyuburkan sifat-sifat kebaikan dalam hati muzakki.

c. Memberikan zakat atau infaq dan lainnya kepada fakir miskin bisa menjaga keseimbangan hidup atau kesenjangan dan menghindari ketidak adilan sosial.

d. Memupuk rasa kasih sayang dan kecintaan orang kaya (aghniya) kepada orang miskin sehingga terjalin keterpaduan antara orang miskin dan orang kaya.

e. Mengikis segala bentuk kejahatan yang bisa terjadi dalam masyarakat akibat kesenjangan, kecemburuan dan ketidakadilan sosial.

f. Menjadi jalan meraih rezeki yang lebih besar dan berkah. Barangsiapa yang membuka pintu rezeki untuk kepentingan agama dan kemanusiaan. Allah akan membuka keran rezeki yang lebih besar, kontan di dunia sekarang. Nabi SAW. menyatakan, tidak akan berkurang harta karena sedekah dan zakat, dijamin tidak akan ada orang menjadi sengsara gara-gara infak 
dan zakat, tidak akan ada orang menjadi menderita gara-gara infak dan zakat.

g. Menjadi sarana mendekatkan diri dan menebalkan keimanan kepada Allah. Dengan cara mudah berinfaq/shadaqah seorang muslim menjadi dekat dengan Allah dan dapat menjaga jarak aman dari harta.

\section{Makna spiritual 'ibādah māliyah dalam kehidupan sehari-hari.}

Harta benda pada hakikatnya hanya milik Allah dan manusia hanya mendapatkan titipan saja dari Allah yang berfungsi sebagai bekal beribadah kepada Allah SWT. Oleh karenanya, memiliki banyak harta benda, berbanding lurus dengan lebih banyak beribadah kepada-Nya. Sebab, harta yang dijadikan sebagai bekal dan sarana ibadah, hal ini menunjukkan harta benda tersebut bermanfaat, bernilai dan akan membuahkan berkah kepada harta dan kehidupan yang bersangkutan.

Makna spiritual ibadah maaliyah, seperti zakat, infaq dan shadaqah termasuk ibadah ijtima'i, yaitu ibadah yang dilaksanakan dalam rangka memenuhi kemaslahatan sosial. Ibadah maliyah memiliki fungsi sosial, dengan 
memberikan ZIS dan lainnya kepada fakir miskin bisa menjaga keseimbangan hidup atau kesenjangan dan menghindari ketidak adilan sosial. Di samping itu, ibadah maaliyah juga akan memupuk rasa kasih sayang dan kecintaan orang kaya (aghniya) kepada yang tidak memiliki harta, sehingga terjalin keterpaduan antara orang miskin dan orang kaya, serta mengikis segala bentuk kejahatan yang bisa terjadi dalam masyarakat akibat kesenjangan dan ketidakadilan sosial.

Zakat merupakan ibadah fardiyah yang berimplikasi luas dalam kehidupan sosial (jama'iyah), ekonomi (iqtishadiyah), politik (siyasiyat), budaya (tsaqafah), pendidikan (tarbiyah) dan aspek kehidupan lainnya. Zakat merefleksikan nilai spiritual. Makna spiritual ibadah maaliyah (zakat) dalam kehidupan manusia sebagai media tazkiyat an nufus, yaitu membersihkan dan menyucikan harta benda dan membersihkan muzakki (orang yang mengeluarkan zakat) dari sifat kikir dan cinta yang berlebih-lebihan kepada harta benda.

Infaq memiliki peran penting dalam pranata keagamaan yang memiliki kaitan secara fungsional terkait pemecahan masalah-masalah kemanusiaan, terutama nasib mereka yang lemah, antara lain: pengentasan kemiskinan 
dan kesenjangan sosial akibat perbedaan dalam pemilikan harta benda. Berinfaq adalah ciri utama orang yang bertaqwa, ciri mukmin yang mengharapkan keuntungan abadi di akhirat berupa surga. Allah akan melipatgandakan pahala bagi orang yang berinfaq dan sebaliknya, tidak mau berinfaq sama dengan menjatuhkan diri ke dalam kebinasaan dan kehancuran. Oleh karena itu, dapat dipahami bahwa makna spiritual infaq dalam kehidupan merupakan refleksi nilai charity (kedermawanan) yang memiliki peran penting dalam pranata keagamaan yang memiliki kaitan secara fungsional terkait pemecahan masalah-masalah kemanusiaan, terutama nasib mereka yang lemah, antara lain: pengentasan kemiskinan dan kesenjangan sosial akibat perbedaan dalam pemilikan harta benda. Shadaqah merupakan indikasi kebenaran iman seseorang dan merefleksikan kesalehan individu dan kesalehan sosial. Sedangkan shadaqah merupakan indikasi kebenaran iman seseorang dan merefleksikan keshalehan individu dan keshalehan sosial. 


\section{Rangkuman}

1. Ibādah māliyah adalah ibadah yang dilakukan dengan menggunakan sarana harta benda sebagai bentuk ta'abbudi kepada Allah. Macam-macam 'Ibādah māliyah dalam Islam adalah zakat, infaq, shadaqah, fidyah, kifarat, qurban atau udhiyyah, aqiqah, al-hadyu, dan dam

2. Urgensi Ibādah māliyah dilihat dari berbagai segi, antara lain: pertama, secara syariat, 'ibādah māliyah sebagai pembuktian ketaatan kepada syariat Allah. Kedua, secara sosial, 'ibādah māliyah berfungsi untuk membangun stabilitas kehidupan sosial dengan mengikis kesenjangan dan menjaga keseimbangan hidup serta menghindari ketidakadilan sosial. Ketiga, secara pribadi, 'ibādah māliyah berfungsi untuk menumbuhkan kepekaan hati pada sesama manusia. Ibadah maaliyah membersihkan hati dari kotoran kebakhilan, keserakahan, kekejaman dan kezaliman terhadap kaum fakir miskin. Keempat, secara perekonomian, 'ibādah māliyah berfungsi untuk mengembangkan pemanfaatan harta, karena harta seseorang akan menjadi bertambah, dan multi manfaatnya, bukan hanya untuk diri sendiri. 
h. Hikmah menjalankan 'ibādah māliyah diantaranya: (a) membersihkan harta dari hak-hak orang lain; (b) menyuburkan sifat-sifat kebaikan; (c) menjaga keseimbangan hidup; (d) memupuk rasa kasih sayang; (e) mengikis jurang kesenjangan, kecemburuan dan ketidakadilan sosial; (f) menjadi jalan meraih rezeki yang lebih besar dan berkah; (g) menjadi sarana mendekatkan diri kepada Allah.

3. Makna spiritual 'ibādah māliyah dalam kehidupan sehari-hari, yaitu zakat sebagai media tazkiyat an nufus, yaitu membersihkan dan menyucikan harta benda, serta membersihkan muzakki dari sifat kikir dan cinta yang berlebih-lebihan kepada harta benda. Infaq mereleksikan nilai kedermawanan yang memiliki peran penting dalam pranata keagamaan yang memiliki kaitan secara fungsional terkait pemecahan masalah-masalah kemanusiaan, terutama nasib mereka yang lemah. Shadaqah merupakan indikasi kebenaran iman seseorang dan merefleksikan kesalehan individu dan kesalehan sosial. 


\section{Latihan/Tugas/Eksperimen}

Mahasiswa mengidentifikasi macam-macam zakat, kemudian melakukan eksperimen terhadap perhitungan zakat sesuai ketentuan syariah.

\section{DAFTAR PUSTAKA}

Djamil, Fathurrahman, Filsafat Hukum Islam, Jakarta: Logos Wacana Ilmu, 1999.

Hafidhuddin, Didin, Panduan Praktis tentang Zakat, Infaq, dan Shadaqah, Jakarta: Gema Insani, 1998

Herry, Munhanif, Tuntunan Praktis Zakat dan Permasalahannya, Cibubur: Variapop, 2012.

Inoed, Amiruddin, dkk., Anatomi Fiqh Zakat : Potret \& Pemahaman Badan Amil Zakat Sumatera Selatan, Yogyakarta : Pustaka Pelajar, 2005.

Qardhawi, Yusuf, Hukum Zakat, alih bahasa: Didin Hafidhuddin dan Hasanuddin, Jakarta: Pustaka Litera Antar Nusa, 1993. 
Rahardjo, M. Dawam, Islam dan Transformasi SosialEkonomi, Yogyakarta: Lembaga Studi Agama dan Filsafat, 1999.

Ridha, M. Taufiq, Perbedaan Zakat, Infaq, Waqaf, Jariyah, Fidyah, Jakarta: Tabung Wakaf Indonesia, tt.

Shihab, Quraish, Wawasan al-Qur'an, Bandung: Mizan: 2003. 


\section{BAB VI \\ AKHLAQ DAN PERANNYA SEBAGAI MODAL \\ SOSIAL \\ BAGI KEBERHASILAN HIDUP SESEORANG}

\section{A. Pendahuluan}

Degradasi moral berupa kesimpangan sosial dan perilaku-perilaku yang tidak manusiawi di Indonesia khususnya, bukanlah hal yang baru, banyak faktor yang mempengaruhinya, di antaranya melalui media elektronik dan di sisi lain adalah faktor manusia itu sendiri yang cenderung mengabaikan dan meninggalkan ajaran Islam dalam kehidupannya. Sebab, akhlak merupakan barometer terhadap kebahagiaan, keamanan dan ketertiban dalam kehidupan manusia dan dapat dikatakan bahwa akhlak merupakan berdirinya suatu umat, sebagaimana shalat sebagai tiang agama. Dengan kata lain, apabila rusak akhlak suatu umat maka rusaklah bangsanya. Di mana nilai-nilai kejujuran, kebenaran dan keadilan merupakan sifat-sifat terpenting dalam agama Islam dalam pembentukan karakter manusia. 
Oleh karena itu, timbulnya pembinaan akhlaq, bersamaan dengan timbulnya kehidupan manusia dan berbagai persoalan mana yang baik dan mana yang buruk bagi tiap orang, walaupun dengan penilaian akal yang sederhana sekalipun pada dasarnya semua ini adalah untuk mengatur tata kehidupan manusia. Hal ini sebagaimana hadirnya Nabi Muhammad SAW. melalui keteladanan akhlaqnya telah terbukti berhasil membawa perubahan besar dan mengubah serta memutar seluruh sendi kehidupan manusia, baik jasmani maupun rohani sesuai petunjuk Allah SWT.

Berdasarkan uraian pendahuluan di atas, capaian pembelajaran pada bab ini adalah:

1. Mahasiswa mampu menjelaskan pengertian akhlak, etika dan moral.

2. Mahasiswa mampu menjelaskan sumber akhlak dalam Islam.

3. Mahasiswa mampu menerapkan akhlak sebagai modal sosial bagi keberhasilan hidup seseorang. 


\section{B. Penyajian Materi}

\section{Pengertian akhlaq, etika dan moral}

Secara etimologi, akhlaq berasal dari bahasa Arab jama' dari bentuk mufradnya ُحْقُ berarti: budi pekerti, perangai, tingkah laku atau tabiat. Kata akhlaq tersebut juga memiliki persesuaian beberapa kata, yaitu:

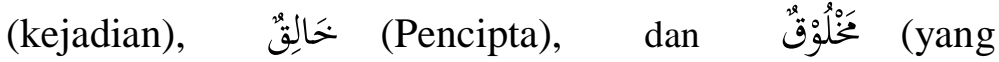
diciptakan). ${ }^{163}$

Luis Ma'luf ${ }^{164}$ mengembangkan definisi tersebut hingga mencakup makna sikap, perilaku, sopan, tabi'at, etika, karakter, kepribadian, dan moral. Makna tersebut, diperkuat dalam al-Qur'an dan al-Hadith sebagai berikut:

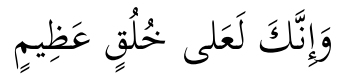

"Dan sesungguhnya kamu benar-benar berbudi pekerti yang agung". 165

163 Zahruddin AR. Pengantar Ilmu Akhlak, (Jakarta: PT. Raja Grafindo Persada, 2004), h. 1.

${ }^{164}$ Luis Ma'luf, Kamus al-Munjid, (Beirut: al-Maktabah alKatulukiyah, tt.)

165 QS. al-Qalaam [68]: 4. 


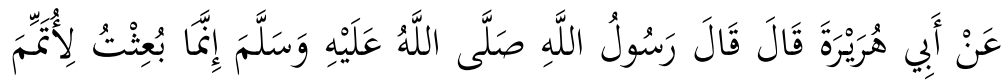

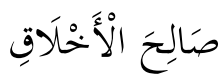

"dari Abu Hurairah berkata; Rasulullah shallallahu 'alaihi wasallam bersabda: "Sesungguhnya aku hanya diutus untuk menyempurnakan akhlaq yang baik."166

Beberapa pengertian akhlaq secara bahasa tersebut di atas, dapat dipahami bahwa makna الََْْْلاَقُُ--خَالِقِقُ " تَخْلُوْقُ yang berarti menciptakan. Hal ini menunjukkan bahwa akhlaq suatu yang mencerminkan perilaku yang menghubungkan antara Allah SWT dan makhlukNya. Berdasar makna akhlaq secara bahasa tersebut, akhlaq adalah seluruh ajaran agama Islam itu sendiri yang mengatur hubungan antara manusia dengan Allah, manusia dengan sesama manusia dan manusia dengan dirinya sendiri serta manusia dengan lingkungan hidup.

Sedangkan akhlaq ditinjau secara terminologi, ada beberapa pakar mengemukakan pengertian akhlak, yaitu:

${ }^{166}$ HR. Ahmad: 8595 
pertama, imam al-Ghazali dalam Moh. Ardani menjelaskan tentang pengertian akhlaq, al-Ghazali mengatakan:

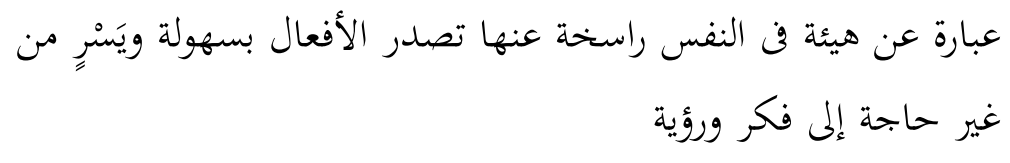

"Suatu sifat yang tertanam dalam jiwa yang daripadanya timbul perbuatan-perbuatan dengan mudah tanpa memerlukan pertimbangan terlebih dahulu."167

Kedua, Ibnu Maskawih dalam Zahruddin, juga menjelaskan pengertikan akhlaq. Ibnu Maskawih mengatakan:

$$
\text { حال للنفس داعية لما إلى أفعالها من غير فكر ولا رؤية }
$$

"Keadaan jiwa seseorang yang mendorong untuk melakukan perbuatan-perbuatan tanpa pertimbangan akal fikiran terlebih dahulu." 168

Ketiga, Abuddin Nata, mencoba menghubungkan makna akhlaq di atas dengan kata Islam, maka akan berbentuk akhlaq Islam. Secara sederhana akhlaq Islam, diartikan sebagai akhlaq yang berdasarkan ajaran Islam

${ }^{167}$ Moh. Ardani, Akhlak Tasawuf, (Jakarta: PT. Mitra Cahaya Utama, 2005), h. 29.

${ }^{168}$ Zahruddin AR. Pengantar Ilmu Akhlak, (Jakarta: PT. Raja Grafindo Persada, 2004), h. 4. 
atau akhlaq yang bersifat Islami. Kata Islam yang berada di belakang kata akhlaq dalam menempati posisi sifat. Dengan demikian, akhlaq Islam adalah perbuatan yang dilakukan dengan mudah, disengaja, mendarah daging dan sumbernya berdasarkan pada ajaran Islam. Dilihat dari segi sifatnya yang universal, maka akhlaq Islam juga bersifat universal. ${ }^{169}$

Pengertian akhlaq Islam dari Abuddin Nata di atas, dapat dipahami lebih menekankan pada sifat mengarahkan, membimbing, mendorong, membangun peradaban manusia dan mengobati bagi penyakit sosial dari jiwa dan mental, serta tujuan berakhlaq yang baik untuk mendapatkan kebahagiaan di dunia dan akhirat. Dengan demikian, akhlaq Islam itu jauh lebih sempurna dibandingkan dengan akhlaq lainnya yang hanya menekankan pada hubungan dengan manusia, maka akhlaq Islam menjelaskan pula tentang cara berhubungan dengan binatang, tumbuh-tumbuhan, air, udara dan lain sebagainya. Dengan cara demikian, masing-masing makhluk merasakan fungsi dan eksistensinya di dunia ini.

${ }^{169}$ Abuddin Nata, Akhlak Tasawuf, (Jakarta: PT. Raja Grafindo Persada, 2003), h. 147. 
Akhlaq adalah tatanan sistem nilai dalam asas sifat dan tingkah laku yang bersumber pada al-Qur'an, sebagaimana dinyatakan dalam firman Allah:

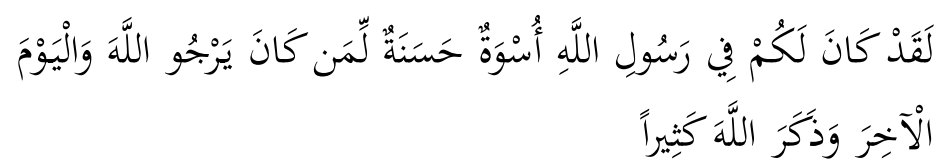

"Sesungguhnya telah ada pada (diri) Rasulullah itu suri teladan yang baik bagimu (yaitu) bagi orang yang mengharap (rahmat) Allah dan (kedatangan) hari kiamat dan dia banyak menyebut Allah". ${ }^{170}$

Berdasar ayat al-Qur'an di atas, standar segala sifat dan tingkah laku Nabi Muhammad SAW, baik lahir maupun batin senantiasa merupakan bimbingan dan petunjuk dari al-Qur'ān. Al-Qur'ān selalu mengajarkan dan membimbing umat Islam untuk berbuat baik dan menjauhi segala perbuatan yang buruk. Akhlaq dapat menciptakan keserasian hubungan antara manusia dengan Allah, manusia dengan manusia, dan antara manusia dengan lingkungannya.

Beberapa pengertian akhlaq secara istilah di atas, jika diperhatikan dengan seksama, tampak bahwa seluruh definisi akhlaq sebagaimana tersebut di atas tidak ada yang saling bertentangan, melainkan saling melengkapi, yang

${ }^{170}$ QS. al-Ahzab [33]: 21. 
menyimpulkan bahwa hakikat akhlaq merupakan sifat yang tertanam kuat dalam jiwa yang nampak dalam perbuatan lahiriah yang dilakukan dengan mudah, tanpa memerlukan pemikiran lagi dan sudah menjadi kebiasaan.

Berbeda dengan pengertian etika, yang lebih dihubungkan dengan nilai tindakan manusia. ${ }^{171}$ Etika merupakan ilmu yang berkenaan tentang yang baik dan buruk serta tentang hak dan kewajiban moral. ${ }^{172}$ Diperkuat oleh Mohammad Nasir bin Omar, ${ }^{173}$ yang menyebutkan bahwa etika adalah sebuah peraturan yang menjadi panduan dalam hidup manusia.

Kata etika berasal dari bahasa Yunani etos yang berarti kebiasaan, perasaan batin atau kecenderungan hati di mana seseorang melakukan perbuatan.

Pengertian etika di atas, dapat dipahami standar menilai didasarkan pada penilaian aspek baik dan

${ }^{171}$ Pius A Partanto dan M. Dahlan al-Barry, Kamus Ilmiah Populer, (Surabaya: Arkola, 1994), h. 61.

${ }^{172}$ EM Zulfajri dan Ratu Aprilia Senja, Kamus Lengkap Bahasa Indonesia, (Jakarta: Aneka Ilmu, 2008), h. 289.

${ }^{173}$ Mohammad Nasir bin Omar, Falsafah Etika: Perbandingan Pendekatan Islam dan Barat, (Kuala Lumpur: Jabatan Perdana Menteri, Bahagian Hal Ehwal Islam, 1986), h. 2003. 
buruknya tingkah laku manusia serta hak dan kewajiban moralitasnya. Etika merupakan aturan atau pola tingkah laku yang dihasilkan oleh akal manusia melalui pemikiran manusia yang ditujukan pada manusia pula. Etika berfungsi sebagai penilai, penentu dan penetap terhadap suatu perbuatan yang dilakukan oleh manusia, yaitu apakah perbuatan tersebut akan dinilai baik, buruk, mulia, terhormat, hina dan sebagainya. Melihat sumbernya, etika bersumberkan dari akal pikiran atau filsafat yang bersifat tidak mutlak, tidak absolut dan berlaku lokal. Keterjangkauan berlakuknya etika, dapat dipahami bersifat terbatas dan selalu mengalami perubahan, sehingga memiliki kekurangan, dan kelemahan.

Sedangkan pengertian moral lebih dihubungkan dengan sistem hidup dan mengarah pada tatanan nilai hidup seseorang. Secara bahasa, moral berasal dari bahasa Inggris, mores (adat istiadat, dan adat kebiasaan). ${ }^{174}$ Abuddin Nata, ${ }^{175}$ menyatakan bahwa moral lebih menfokuskan pada suatu nilai atau sistem hidup yang

${ }^{174}$ Jhon M. Echols dan Hassan Shadily, An English-Indonesian Dictionary, (Jakarta: PT Gramedia Pustaka Utama, 2008), h. 386.

175 Abuddin Nata, Akhlak Tasawuf dan Karakter Mulia, (Jakarta: Rajawali Pers, 2013), h. 80. 
dilaksanakan atau diberlakukan oleh masyarakat. Nilai atau sistem hidup tersebut diyakini oleh masyarakat sebagai yang akan memberikan harapan munculnya kebahagiaan dan ketenteraman.

Perbedaan akhlaq, etika dan moral di atas, dapat dipahami sebagaimana pada tabel di bawah ini:

\begin{tabular}{|l|l|l|l|}
\hline \multicolumn{1}{|c|}{ Aspek } & \multicolumn{1}{|c|}{ Akhlak } & \multicolumn{1}{|c|}{ Etika } & \multicolumn{1}{c|}{ Moral } \\
\hline Standar & $\begin{array}{l}\text { Al-Qur'an dan } \\
\text { As-Sunah }\end{array}$ & $\begin{array}{l}\text { Adat } \\
\text { kebiasaan } \\
\text { kesepakatan }\end{array}$ & $\begin{array}{l}\text { Adat } \\
\text { kebiasaan } \\
\text { kesepakatan }\end{array}$ \\
\hline Keberlakuan nilai & $\begin{array}{l}\text { Universal } \\
\text { Abadi }\end{array}$ & $\begin{array}{l}\text { Lokal } \\
\text { temporal }\end{array}$ & $\begin{array}{l}\text { Lokal } \\
\text { temporal }\end{array}$ \\
\hline Jangkauan Nilai & $\begin{array}{l}\text { Dunia dan } \\
\text { Akhirat }\end{array}$ & Dunia & Dunia \\
\hline Derajat Nilai & Pahala & $\begin{array}{l}\text { Kepatutan } \\
\text { kesopanan }\end{array}$ & $\begin{array}{l}\text { Kepatutan } \\
\text { kesopanan }\end{array}$ \\
\hline
\end{tabular}

Berdasarkan perbedaan pada tabel di atas, dapat diambil kesimpulan bahwa etika adalah ilmu, moral adalah ajaran, dan akhlak adalah tingkah laku manusia. Akhlaq mempunyai pengertian yang lebih luas dan mencakup pengertian etika dan moral. Akhlaq memiliki standar, keberlakukan nilai, jangkauan nilai dan derajat nilai lebih 
luas daripada etika dan moral. Standar untuk menjadi menilai perbuatan manusia, akhlaq berdasarkan wahyu, yaitu al-Qur'an dan as-Sunnah bersifat mutlak kebenarannya. Sedangkan etika dan moral menilai perbuatan manusia dilihat dari segi adat kebiasaan yang sudah menjadi kesepakatan bersama. Keberlakukan akhlaq berlaku universal kepada semua manusia dan bersifat abadi atau tidak mengalami perubahan oleh waktu dan kemajuan peradaban manusia. Jangkauan dan derajat nilai etika dan moral berdasarkan kepatutan kesopanan yang berlaku di masyarakat. Sementara akhlaq melampui ruang dan waktu, artinya tidak dibatasi di dunia ini saja, melainkan juga memiliki implikasi pada kehidupan di akhirat. Hal ini dijelasksan dalam firman Allah:

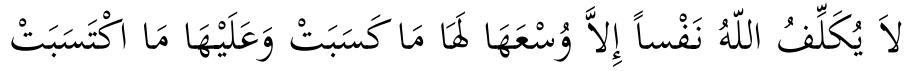

"Allah tidak membebani seseorang melainkan sesuai dengan kesanggupannya. Ia mendapat pahala (dari kebajikan) yang diusahakannya dan ia mendapat siksa (dari kejahatan) yang dikerjakannya".

${ }^{176}$ QS. al-Baqarah [2]: 286. 


\section{Sumber akhlaq dalam Islam}

Akhlak Islam, karena merupakan sistem akhlaq yang berdasarkan kepada Allah melalui wahyuNya (al-Qur'an dan al-Hadits), maka tentunya sesuai pula dengan dasar dari pada agama Islam tersebut. Ahmad Mustofa, ${ }^{177}$ mengatakan bahwa sumber pokok akhlaq dalam Islam adalah al-Qur'an dan al-Hadits yang merupakan sumber utama dari agama itu sendiri. Hal ini diperkuat dengan pribadi Nabi Muhammad SAW dalam ajaran Islam sebagai contoh yang paling tepat untuk dijadikan teladan dalam membentuk kepribadian manusia dalam kesehariannya. Hal ini sebagaimana riwayat hadits berikut:

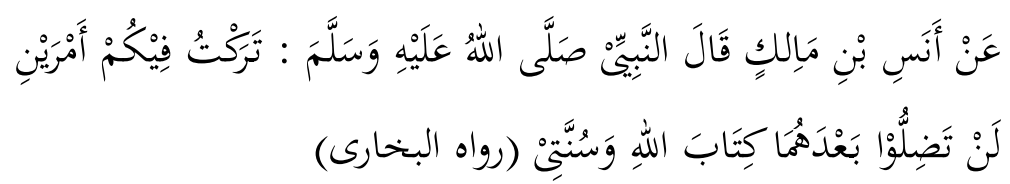

"Dari Anas bin Malik r.a. berkata, bahwa Nabi saw bersabda,"telah ku tinggalkan atas kamu sekalian dua perkara, yang apabila kamu berpegang kepada

${ }^{177}$ Ahmad Mustofa, Akhlak Tasawuf, (Bandung: CV Pustaka Setia, 2007), h. 149-150. 
keduanya, maka tidak akan tersesat, yaitu Kitab Allah dan sunnah Rasul- Nya". ${ }^{178}$ (HR. Bukhari).

Berdasar uraian di atas, dapat dipahami bahwa untuk dapat memiliki akhlaa yang sesuai dengan tuntutan Allah dan RasulNya, maka diperlukan melakukan dua inti dari

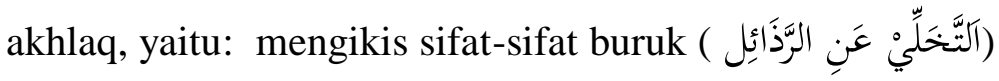
dan menghiasi diri dengan sifat-sifat yang utama ( التَّحَلِّيْ برلْفَضَائلِ Hal ini dipertegaskan bahwa akhlaq Islam digambarkan dalam firmanNya berikut:

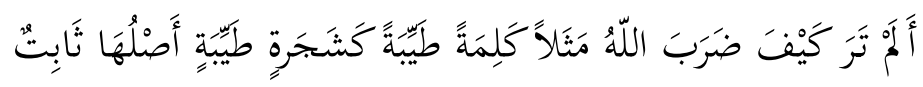

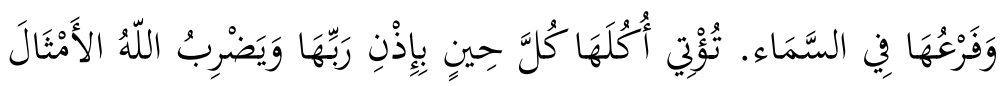

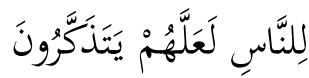

“Tidakkah kamu perhatikan bagaimana Allah telah membuat perumpamaan kalimat yang baik seperti pohon yang baik, akarnya teguh dan cabangnya (menjulang) ke langit, pohon itu memberikan buahnya pada setiap musim dengan seizin Tuhannya. Allah

${ }^{178}$ HR. al-Bukhari. 
membuat perumpamaan-perumpamaan itu untuk manusia supaya mereka selalu ingat". ${ }^{179}$

Ayat di atas, menjelaskan bahwa sesorang yang berakhlaq Islam, seperti memiliki akar yang teguh ( سليمة (العقيدة و صحيحة العبادة), cabangnya ke langit, berarti memiliki Orientasi amal shaleh, dan memberikan buahnya pada setiap musim (نافيع لغيره) berarti menjadikan hidupnya selalu bermafaat dan berarti bagi orang lain. Benar akidah dan ibadahnya ( سليمة العقيدة و صحيحة العبادة), artinya, seseorang memiliki keyakinan keimanan bahwa ia total mengikrarkan hidupnya ikhlas karena Allah dan selalu hidupnya penuh arti dan makna bagi orang lain. Hal ini sebagaimana digambarkan dalam firman Allah:

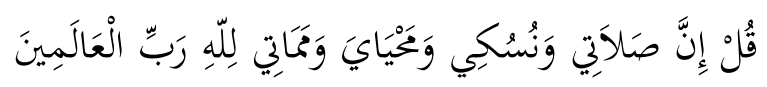

"Katakanlah: "Sesungguhnya shalat, ibadah, hidup dan matiku hanyalah untuk Allah, Tuhan semesta alam". ${ }^{180}$

${ }^{179}$ QS. Ibrahim [14]: 24-25. 


\section{Peran akhlaq dalam keberhasilan hidup}

Akhlaq adalah sifat yang melekat pada diri seseorang dan menjadi identitas dirinya, sebagaimana akhlak mulia dijadikan pondasi utama dalam pembentukan pribadi Muslim paripurna. Sedemikian pentingnya akhlaq bagi seseorang, maka terbentuknya akhlaq mulia sangat ditentukan oleh penanaman nilai-nilai kemuliaan akhlaq sejak dini, agar tidak terdampak arus negatif dari modernisasi dan globalisasi. ${ }^{181}$

Akhlaq dalam perspektif Islam, merupakan syariat Islam yang dijadikan sebagai alat untuk menentukan baikburuknya sifat dan tingkah laku seseorang berdasarkan alQu'an dan al-Hadits. Hal-hal yang baik menurut al-Qur'an dan al-Hadits, itulah yang baik untuk dijadikan pegangan dalam kehidupan sehari-hari. Sebaliknya, apa yang buruk menurut keduanya, itulah yang tidak baik dan harus dijauhi. Perbuatan baik membutuhkan usaha dan pembiasaan setiap hari, yakni berusaha melakukan perbuatan baik dan berusaha menjauhi perbuatan yang

${ }^{180}$ QS. al-An'aam [6]: 162.

${ }^{181}$ Subahri, S., Aktualisasi Akhlak Dalam Pendidikan. Islamuna: Jurnal Studi Islam, 2015, h. 167. 
buruk yang pada gilirannya akan membentuk sifat yang tertanam dalam jiwa dan teraktualisasi dalam ranah kehidupan.

Jika tujuan hidup adalah membentuk pribadi yang bertaqwa, yakni pribadi yang mampu melaksanakan segala perintah agama dan meninggalkan segala larangan agama. Berarti, menjauhi perbuatan-perbuatan jahat (al-akhlāq almadzmūmah) dan melakukan perbuatan-perbuatan baik (al-akhlāq al-karīmah) merupakan perintah Allah ditujukan kepada manusia untuk melakukan perbuatanperbuatan baik dan menjauhi larangan berbuat jahat.

Abdullah ${ }^{182}$ menguatkan bahwa ukuran orang yang bertaqwa dapat dilihat pada perilaku seseorang yang tercermin pada kepribadian dirinya yang selalu menjaga untuk berakhlaq mulia, berbuat baik, dan berbudi luhur.

Ramayulis, akhlaq dalam Islam bertujuan untuk melahirkan manusia yang memiliki keutamaan (al-

${ }^{182}$ Abdullah, M.Y., Studi Akhlak dalam Perspektif al-Quran, (Jakarta: Azmah, 2007), h. 5. 
fadhilah), yaitu menjadi manusia yang paling bermanfaat bagi manusia lainnya. ${ }^{183}$

Barmawie Umary dalam bukunya materi akhlak menyebutkan bahwa tujuan berakhlaq adalah hubungan umat Islam dengan Allah SWT dan sesama makhluk selalu terpelihara dengan baik dan harmonis. ${ }^{184}$ Sementara, Omar M. M. al-Toumy al-Syaibany, tujuan akhlak adalah menciptakan kebahagian dunia dan akhirat, kesempurnaan bagi individu dan menciptakan kebahagian, kemajuan, kekuataan dan keteguhan bagi masyarakat. ${ }^{185}$

Beberapa uraian tujuan akhlaq dalam Islam di atas, dapat disimpulkan bahwa peran akhlaq dalam keberhasilan hidup manusia pada prinsipnya melalui akhlaq Islam, manusia akan memperoleh keberhasilan hidupnya, yakni kebahagian dan keharmonisan dalam berhubungan dengan Allah SWT, di samping berhubungan dengan sesama makhluk dan juga alam sekitar.

${ }^{183}$ Ramayulis, Ilmu Pendidikan Islam, (Jakarta: Kalam Mulia, 2004), h. 115.

${ }^{184}$ Barnawie Umar, Materi Akhlak, (Solo: CV Ramadhani, 2003), h. 2.

${ }^{185}$ M. Al-Toumy Al-Syaibany, Filsafat Pendidikan Islam, (Jakarta:Bulan Bintang, 2003), h. 346. 
Syauqi Bek dalam Kahar Mansur menjelaskan bahwa sesungguhnya eksisitensi suatu masyarakat sangat tergantung pada akhlaqnya, jika masyarakat telah kehilangan akhlaqnya, maka binasalah masyarakat tersebut. Hal ini sebagaimana ungkapan dalam syairnya:

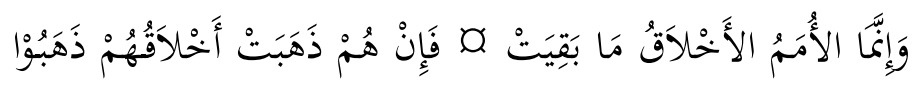

"Sesungguhnya kejayaan suatu umat (bangsa) terletak pada akhlaknya selagi mereka berakhlak dan berbudi perangai utama, jika pada mereka telah hilang akhlaknya, maka jatuhlah umat (bangsa) itu". ${ }^{186}$

Dengan demikian, akhlaq merupakan modal sosial (social capital) yang penting bagi masyarakt, karena sebagai filter dan benteng dari budaya yang dapat menghancurkan sendi-sendi kehidupannya.

\section{Rangkuman}

1. Hakikat akhlaq merupakan sifat yang tertanam kuat dalam jiwa yang nampak dalam perbuatan lahiriah yang dilakukan dengan mudah, tanpa memerlukan pemikiran lagi dan sudah menjadi kebiasaan. Etika

${ }^{186}$ Kahar Mansur, Membina Moral dan Akhlak, (Jakarta: Rineka Cipta, 1994), h. 3. 
adalah standar menilai didasarkan pada penilaian aspek baik dan buruknya tingkah laku manusia serta hak dan kewajiban moralitasnya. Moral lebih dihubungkan dengan sistem hidup dan mengarah pada tatanan nilai hidup seseorang. Perbedaannya, etika: ilmu, moral: ajaran, dan akhlak adalah tingkah laku manusia

2. Sumber pokok akhlaq dalam Islam adalah al-Qur'an dan al-Hadits.

3. Peran akhlaq dalam keberhasilan hidup, dengan akhlaq, manusia akan memperoleh keberhasilan hidupnya, yakni kebahagian dan keharmonisan dalam berhubungan dengan Allah SWT, di samping berhubungan dengan sesama makhluk dan juga alam sekitar. Urgensi lain, akhlaq dijadikan sebagai alat untuk menentukan baik-buruknya sifat dan tingkah laku seseorang berdasarkan al-Qu'an dan al-Hadits.

\section{Latihan/Tugas/Eksperimen}

Mahasiswa mendiskusikan tentang akhlaq mahmudah (al-karimah), yaitu akhlaq terhadap Allah, akhlaq terhadap diri sendiri, dan akhlaq terhadap sesama 
manusia dalam al-Qur'an dan al-Hadits serta mengidentifikasi bentuk-bentuk akhlaq mahmudah tersebut.

\section{DAFTAR PUSTAKA}

Abdullah, M. Y., Studi Akhlak dalam Perspektif al-Quran, Jakarta: Azmah, 2007.

Al-Syaibany, M. Al-Toumy, Filsafat Pendidikan Islam, Jakarta:Bulan Bintang, 2003.

Ardani, Moh., Akhlak Tasawuf, Jakarta: PT. Mitra Cahaya Utama, 2005.

Compact Disc (CD) Ensiklopedi Hadits 9 Imam.

Departemen Agama RI, Al-Qur'an dan Tafsirnya, Jakarta:

Departemen Agama RI, 2010.

Echols, Jhon M. dan Shadily, Hassan, An English-Indonesian Dictionary, Jakarta: PT Gramedia Pustaka Utama, 2008.

Ma'luf, Luis, Kamus al-Munjid, Beirut: aI-Maktabah alKatulukiyah, tt.

Mansur, Kahar, Membina Moral dan Akhlak, Jakarta: Rineka Cipta, 1994. 
Mustofa, Ahmad, Akhlak Tasawuf, Bandung: CV Pustaka Setia, 2007.

Nata, Abuddin, Akhlak Tasawuf, Jakarta: PT. Raja Grafindo Persada, 2003.

, Akhlak Tasawuf dan Karakter Mulia, Jakarta: Rajawali Pers, 2013.

Omar, Mohammad Nasir bin, Falsafah Etika: Perbandingan Pendekatan Islam dan Barat, Kuala Lumpur: Jabatan Perdana Menteri, Bahagian Hal Ehwal Islam, 1986.

Partanto, Pius A dan al-Barry, M. Dahlan, Kamus Ilmiah Populer, Surabaya: Arkola, 1994.

Ramayulis, Ilmu Pendidikan Islam, Jakarta: Kalam Mulia, 2004.

Subahri, S., Aktualisasi Akhlak Dalam Pendidikan. Islamuna: Jurnal Studi Islam, 2015.

Umar, Barnawie, Materi Akhlak, Solo: CV Ramadhani, 2003.

Zahruddin AR. Pengantar Ilmu Akhlak, Jakarta: PT. Raja Grafindo Persada, 2004.

Zulfajri, EM dan Aprilia, Ratu, Senja, Kamus Lengkap Bahasa Indonesia, Jakarta: Aneka Ilmu, 2008 


\section{BAB VII \\ MACAM-MACAM AKHLAK DAN PERAN AKHLAK \\ DALAM KEHIDUPAN BERBANGSA DAN \\ BERNEGARA}

\begin{tabular}{|l|l|l|}
\hline Nama Mata Kuliah & $:$ & $\begin{array}{l}\text { IBADAH, AKHLAK \& } \\
\text { MUAMALAH }\end{array}$ \\
\hline Pembelajaran & $:$ & $\begin{array}{l}\text { Mampu Menguasai konsep korelasi } \\
\text { ibadah dan akhlak dalam hubungan } \\
\text { sosial manusia (muamalah) } \\
\text { sehingga membangun motivasi } \\
\text { ibadah yang bisa menunjukkan }\end{array}$ \\
\hline Kemampuan Akhir & $:$ & $\begin{array}{l}\text { Mengidentifikasi macam-macam } \\
\text { pada perubahan perilaku positif. }\end{array}$ \\
\hline yang diharapkan & & $\begin{array}{l}\text { kehidupan dan peran akhlak dalam } \\
\text { bernegara. }\end{array}$ \\
\hline Alokasi Waktu & $:$ & 100 menit \\
\hline Pertemuan ke- & $:$ & 9 \\
\hline Indikator & $:$ & $\begin{array}{l}9.1 \text { Menguasai konsep: } \\
\text { aknlak terhadap Allah dan }\end{array}$ \\
\hline
\end{tabular}




\begin{tabular}{|l|l|l|}
\hline & & $\begin{array}{c}\text { b. Akhlak individual dan sosial } \\
\text { c. Akhlak terhadap } \\
\text { Lingkungan }\end{array}$ \\
9.2 Mempertegas tentang peranan \\
akhlak dalam kehidupan \\
berbangsa dan bernegara
\end{tabular}

\section{A. Pendahuluan}

Pada bab ini penulis membahas tentang macam-macam akhlak dan peran akhlak dalam kehidupan berbangsa dan bernegara. Diharapkan setelah membacanya, mahasiswa menguasai konsep tentang akhlak karimah yang harus dibangun dalam pribadinya baik dalam bentuk hubungan hablunminallah maupun hablunminannaas.

\section{B. Penyajian Materi}

\section{Akhlak terhadap Allah \& Rasul}

Prinsip dasar dalam aqidah Islam adalah Percaya terhadap Allah dan Rasul-Nya. Maka terkait dengan hal tersebut, akhlak pertama yang harus dikenal oleh seorang Muslim adalah Akhlak 
terhadap Allah dan Rasul-Nya, karena akhlak ini menjadi akhlak yang tertinggi nilainya dalam agama Islam.

Akhlak kepada Allah sebagai akhlak yang paling utama karena Allah adalah Sang Pencipta; yang menciptakan alam semesta, termasuk juga manusia, sehingga mempunyai akhlak yang baik kepada Allah merupakan suatu kewajiban bagi seorang Muslim sebagai salah satu wujud penghambaan dan pengakuan manusia bahwa Allah Dzat yang Maha Kuasa. Menurut Yunahar Ilyas, ada 8 sifat dasar yang berkaitan dengan Akhlak terhadap Allah (Ilyas, 2014) antara lain:

1. Taqwa (QS.2:177, QS.65:2-4)

2. Cinta dan Ridha (QS.2:165)

3. Ikhlas (QS.98:5)

4. Khauf (QS. 35:28) dan Raja' (QS. 39:53) $)^{187}$

5. Tawakkal (QS.11:123)

6. Syukur (QS.14:7, QS.31:12)

7. Muraqabah (QS.6:59, QS.4:1) ${ }^{188}$

${ }^{187}$ Khauf bermakna takut, sedangkan Raja' bermakna berharap. Yang dimaksud disini adalah rasa takut dan berharap hanya kepada Allah SWT. ${ }^{188}$ Muraqabah adalah kesadaran seorang Muslim bahwa ia selalu berada dalam pengawasan Allah SWT. (Ilyas, 2014) 
8. Taubat (QS.24:31)

Dari tahapan mengenal akhlak kepada Allah SWT, selanjutnya seorang Muslim harus kenal dengan akhlak kepada Nabi Muhammad SAW sebagai manusia utama, Rasul pengemban risalah kenabian yang terakhir, sangat memperdulikan kepentingan umatnya dan begitu menyayangi umatnya, hal itu tergambar jelas dalam firman Allah

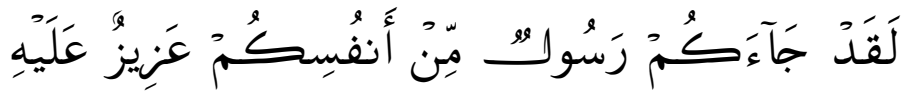

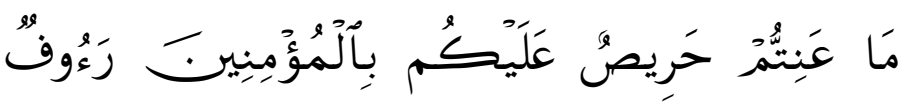

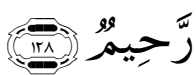

Sungguh telah datang kepadamu seorang Rasul dari kaummu sendiri, berat terasa olehnya penderitaanmu, sangat menginginkan (keimanan dan keselamatan) bagimu, Amat belas kasihan lagi Penyayang terhadap orang-orang mukmin. (QS.atTaubah 9:28)

Maka ayat ini menjadi motivasi bagi umat Islam agar senantiasa menjaga akhlak yang luhur terhadap Rasulullah Muhammad SAW. 
Menurut Marzuki (2009:22) Akhlak terhadap Rasulullah SAW bisa direalisasikan dengan beberapa cara antara lain:

1. Mencintai dan memuliakan Rasul (QS. AtTaubah [9]:24);

2. Mengikuti dan menaati Rasul (QS. An-Nisa [4]:59);

3. Mengucapkan shalawat dan salam (QS. AlAhzab [33]:56)

\section{Akhlak individual \& sosial}

Seorang Muslim harus mempunyai standar akhlak Islami yang menjadi dasar dalam kehidupannya. Allah melalui Rasulullah SAW mengajarkan banyak etika kehidupan yang harus dimiliki secara individual oleh setiap Muslim. Karena dalam hadis, Rasulullah SAW seringkali memberikan motivasi kepada Umatnya untuk selalu berlaku baik. Sebagaimana dalam hadis yang diriwayatkan oleh Abu Darda' RA, Rasulullah SAW bersabda: 


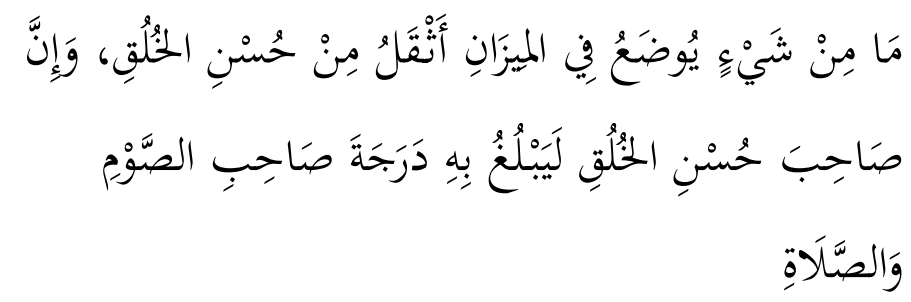

"Tidak ada sesuatu yang diletakkan pada timbangan hari kiamat yang lebih berat daripada akhlak mulia, dan sesungguhnya orang yang berakhlak mulia bisa mencapai derajat orang yang berpuasa dan shalat." (HR. Imam at-Tirmidzi)

Maka seorang Muslim harus selalu membiasakan diri untuk berbuat baik kepada diri sendiri maupun orang lain. Berikut beberapa akhlak individu yang harus dimiliki oleh setiap Muslim:

1. Benar atau Jujur (Shiddiq) (HR. Imam alBukhary)

2. Dapat dipercaya (Amanah) (QS.4:58)

3. Teguh Pendirian (Istiqamah) (QS.11:112)

4. Menjaga Harga Diri (Iffah) (QS.2:273)

5. Bersungguh-sungguh (Mujahadah) (QS.29:69)

6. Berani (Syaja'ah) (QS. 8:15-16)

7. Rendah Hati (Tawadhu') (QS. 25:63)

8. Malu (HR. Tirmidzi)

9. Sabar (QS. 2:155-157) 
10. Pemaaf (QS. 3:133-134)

Merujuk pada hadis yang tersebut di atas, selain akhlak individual, seorang Muslim juga harus memiliki etika dalam berinteraksi sosial dengan orang lain. Keharusan tersebut dikarenakan setiap individu memiliki pemikiran, keinginan dan keyakinan yang berbeda-beda, sehingga Muslim yang baik harus memiliki dasar-dasar akhlak sosial yang telah diajarkan Allah melalui al-Qur'an dan dicontohkan Rasulullah dalam as-Sunnah. Beberapa contoh dari akhlak sosial, antara lain:

1. Saling Menyayangi (QS. 3:135)

2. Saling Menasehati (QS. 103:3)

3. Saling Menghormati (QS.60:8)

4. Berlaku Adil (QS. 4:58)

5. Menjaga Persaudaraan (QS. al-Hujurat:10)

6. Tolong Menolong dalam Kebaikan (QS.5:2)

7. Bermusyawarah (QS.3:159)

Kekuatan karakter seorang muslim pada dasarnya adalah terletak pada kekuatan akhlak karimahnya. Seorang Muslim yang tangguh lebih dicintai oleh Allah daripada seorang Muslim yang 
lemah. (Tuasikal:) Dalam hadis yang diriwayatkan oleh Abu Hurairah RA, Rasulullah bersabda:

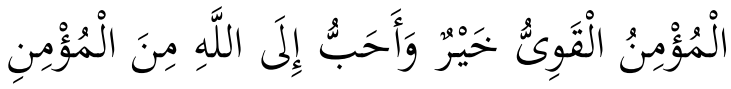

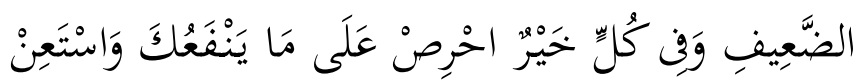

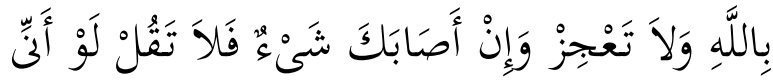

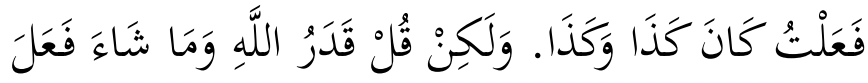

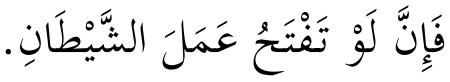

"Mukmin yang kuat lebih baik dan lebih dicintai oleh Allah daripada Mukmin yang lemah. Namun keduanya tetap memiliki kebaikan. Bersemangatlah atas hal-hal yang bermanfaat bagimu. Minta tolonglah kepada Allah dan janganlah menjadi lemah. Jika engkau tertimpa suatu musibah, maka janganlah engkau mengatakan: Jika aku melakukan demikian dan demikian. Akan tetapi hendaknya kamu mengatakan: Ini sudah jadi takdir Allah, setiap apa yang dikehendakiNya maka pasti terjadi. Karena perkataan law ( ؤ ) -Seandainya- itu dapat membuka pintu syaitan."

Hadis tersebut di atas merupakan motivasi bagi setiap muslim untuk tidak putus asa dalam berbuat baik. Meski perlu menjadi catatan bahwa Allah lebih senang melihat muslim yang kuat, tetapi tetap ada kebaikan antara keduanya. Selalu ada 
kebaikan dalam setiap hal bermanfaat yang dilakukan.

\section{Akhlak Terhadap Lingkungan}

Manusia sebagai pengemban amanah khalifah fi al-ardh, tidak hanya mempunyai kewajiban menjaga hubungan baik dengan pencipta dan antar sesama saja, melainkan juga harus memperhatikan keadaan lingkungan dan alam sekitar. Karena pada kenyataannya apabila melihat kerusakan yang terjadi di bumi saat ini tidak lain adalah akibat ulah manusia yang tidak mampu mengendalikan keserakahannya ketika menemukan kekayaan bumi. Fenomena kerusakan bumi akibat perbuatan manusia ini telah diperingatkan Allah dalam al-Qur'an,
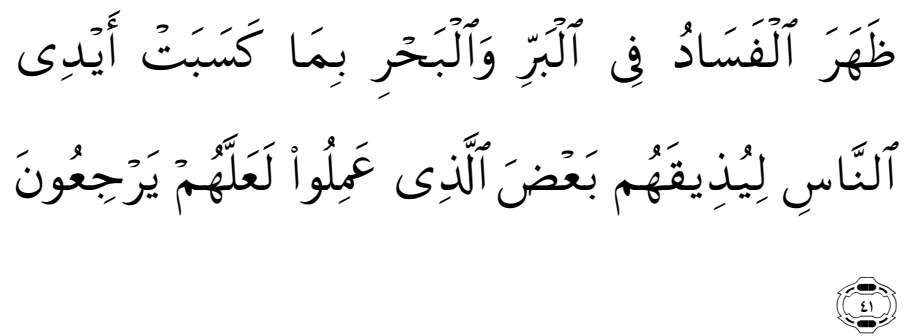

Telah nampak kerusakan di darat dan di laut disebabkan karena perbuatan tangan manusia, 
supaya Allah merasakan kepada mereka sebahagian dari (akibat) perbuatan mereka, agar mereka kembali (ke jalan yang benar). (QS. ar-Ruum 30:41)

Ayat di atas dengan jelas menerangkan bahwa telah nyata dan dapat dilihat secara nyata kerusakan yang terjadi di bumi. Menurut Dr. Ahmad Zain an-Najah, kerusakan yang dimaksud bukan hanya kerusakan non fisik seperti dekadensi moral, meningkatnya pecandu narkoba, perilaku seks menyimpang. Hal ini juga mencakup kerusakan fisik seperti bencana alam, merebaknya berbagai macam penyakit, kerusakan ekosistem dan lain sebagainya.

Maka untuk mengantisipasi kerusakan yang sudah mulai mengakar agar tidak semakin mendalam, selayaknya seorang muslim dari sejak dini mengenal tentang akhlak terhadap lingkungan, contoh penerapan akhlak lingkungan diantaranya:

1. Menjaga kebersihan (QS.2:222)

2. Menyayangi hewan (QS.6:38, HR. Muslim \& Abu Dawud)

3. Melakukan penghijauan (QS.28:77)

4. Menghidupkan lahan mati (QS.7:56) 
5. Menjaga stabilitas alam (keberadaan kekayaan alam yang dapat diperbaharui maupun yang tidak dapat diperbaharui) (QS.7:56-58)

\section{Peran akhlak dalam kehidupan berbangsa dan bernegara}

Islam dari awal penyebarannya telah menegaskan bahwa akhlak mempunyai kedudukan penting dalam kehidupan, sehingga tidak ada hal yang lebih utama bagi Nabi Muhammad SAW selaku penutup risalah kenabian setelah memperkenalkan aqidah islamiyah, selain untuk menyempurnakan akhlak manusia di bumi. Hal ini sebagaimana termaktub dalam hadits:

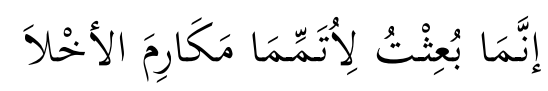

Bahwa sesungguhnya aku di utus untuk menyempurnakan kemuliaan akhlak. (HR. Ahmad)

Karena itu pula Allah benar-benar membentuk sosok Nabi Muhammad dengan akhlaknya yang luhur sebagai tokoh utama peradaban Islam, Allah SWT dalam QS. Al-Ahzab ayat 21 berfirman: 


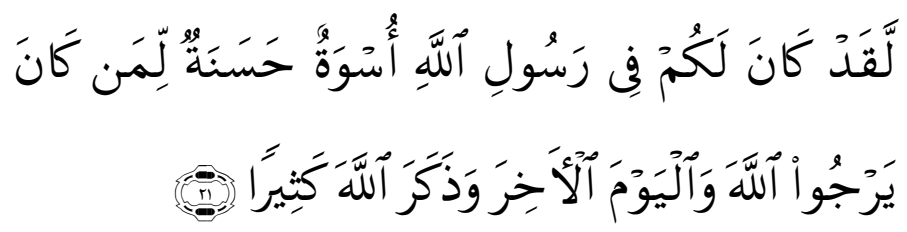

Sesungguhnya telah ada pada (diri) Rasulullah itu suri teladan yang baik bagimu (yaitu) bagi orang yang mengharap (rahmat) Allah dan (kedatangan) hari kiamat dan Dia banyak menyebut Allah.

Sejarah kepemimpinan Rasulullah dan kegemilangan Islam di abad pertengahan mengajarkan bahwa akhlak karimah atau budi pekerti yang luhur merupakan pondasi dasar terbentuknya sebuah bangsa yang tangguh dan berkarakter.

Akan tetapi dalam ajaran Islam kekuatan akhlak mulia tidak memiliki nilai tinggi tanpa dilandasi aqidah Islamiyah yang baik, karena keberkahan itu tercurah kepada suatu negeri sebab ketaatan penduduknya kepada Allah SWT, hal ini sebagaimana firman-Nya QS. Al-A'raaf ayat 96 : 


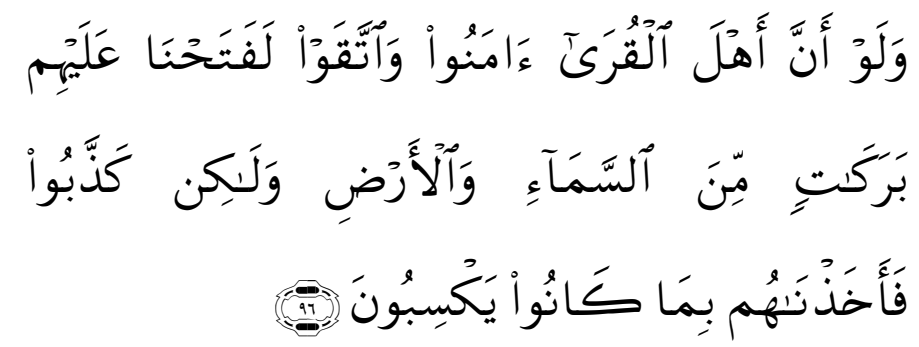

Jikalau Sekiranya penduduk negeri-negeri beriman dan bertakwa, pastilah Kami akan melimpahkan kepada mereka berkah dari langit dan bumi, tetapi mereka mendustakan (ayat-ayat Kami) itu, Maka Kami siksa mereka disebabkan perbuatannya.

Apabila dua hal ini (aqidah dan akhlak) tertanam kuat dalam ideologi suatu bangsa, maka disitulah muncul istilah Baldatun Thayyibatun wa Rabbun Ghafur sebuah istilah yang menggambarkan keadaan negeri yang dilimpahi Allah rahmat-Nya melalui kekayaan alam yang dimiliki, karena penduduknya yang selalu taat menjalankan perintahNya.

\section{Rangkuman}

Rangkuman materi dalam bab ini, antara lain:

1. Akhlak terpuji bagi Allah SWT antara lain: Taqwa (QS.2:177, QS.65:2-4); Cinta dan Ridha (QS.2:165); Ikhlas (QS.98:5); Khauf (QS. 35:28) dan Raja' (QS. 
39:53); Tawakkal (QS.11:123); Syukur (QS.14:7, QS.31:12); Muraqabah (QS.6:59, QS.4:1); Taubat (QS.24:31). Sedangkan akhlak terpuji bagi Rasulullah SAW: Mencintai dan memuliakan Rasul (QS. AtTaubah [9]:24); Mengikuti dan menaati Rasul (QS. An-Nisa [4]:59); Mengucapkan shalawat dan salam (QS. Al-Ahzab [33]:56).

2. Akhlak individual yang harus dimiliki seorang Muslim, diantaranya: Benar atau Jujur (Shiddiq) (HR. Imam al-Bukhary); Dapat dipercaya (Amanah) (QS.4:58); Teguh Pendirian (Istiqamah) (QS.11:112); Menjaga Harga Diri (Iffah) (QS.2:273); Bersungguhsungguh (Mujahadah) (QS.29:69); Berani (Syaja'ah) (QS. 8:15-16); Rendah Hati (Tawadhu') (QS. 25:63); Malu (HR. Tirmidzi); Sabar (QS. 2:155-157); Pemaaf (QS. 3:133-134). Sedangkan Akhlak Sosial yang harus dimiliki seorang muslim antara lain: Saling Menyayangi (QS. 3:135); Saling Menasehati (QS. 103:3); Saling Menghormati (QS.60:8); Berlaku Adil (QS. 4:58); Menjaga Persaudaraan (QS. alHujurat:10); Tolong Menolong dalam Kebaikan (QS.5:2); Bermusyawarah (QS.3:159). 
3. Akhlak terhadap lingkungan meliputi: Menjaga kebersihan (QS.2:222); Menyayangi hewan (QS.6:38, HR. Muslim \& Abu Dawud); Melakukan penghijauan (QS.28:77); Menghidupkan lahan mati (QS.7:56); Menjaga stabilitas alam (keberadaan kekayaan alam yang dapat diperbaharui maupun yang tidak dapat diperbaharui) (QS.7:56-58)

4. Dalam agama Islam peran akhlak dalam kehidupan berbangsa dan bernegara memiliki fungsi yang sangat fundamental, karena pada dasarnya kualitas suatu bangsa ditentukan pada moralitas masyarakatnya. Suatu negara yang ideal di mata Allah adalah Negara yang selain diberikan Allah anugerah sumber daya alam yang berlimpah, juga penduduknya beriman dan taat pada hukum Allah. Itulah yang diistilahkan dalam al-Qur'an Baldatun Thayyibatun wa Rabbun Ghafur.

\section{Latihan/Tugas}

Tugas menuliskan dalil al-Qur'an tentang Akhlak Individu beserta artinya! 


\section{Daftar Pustaka}

Ilyas, Yunahar. Kuliah Akhlaq, Cet.Ke-13 (Yogyakarta:

LPPI, 2014)

Thabbarah, Afif 'Abd al-Fattah. Ruh ad-Din al-Islami (Beirut: Dar al-Ilmi li Malayin, 1978)

Munawwir, Ahmad Darson. Kamus Arab-Indonesia, (Yogyakarta: Al-Munawwir, 1984)

Sabiq, Sayyid. Islamuna, (Beirut: Dar Al-Fikr, 1982)

http://www.ahmadzain.com/read/ilmu/360/kerusakan-

lingkungan-dan-dosa-manusia/ unduh tgl 10-06-2016 http://uin-suska.ac.id/2015/09/07/akhlak-terhadap-

lingkungan-dr-husni-thamrin/ unduh tgl 09-06-2016 https://rumaysho.com/265-tetap-semangat-dalam-halyang-bermanfaat.html unduh tgl 08-07-2017 


\section{BAB VIII}

\section{AKHLAK DALAM KELUARGA DAN LARANGAN KEKERASAN DALAM RUMAH TANGGA}

\begin{tabular}{|c|c|c|}
\hline Nama Mata Kuliah & : & $\begin{array}{l}\text { IBADAH, AKHLAK \& } \\
\text { MUAMALAH }\end{array}$ \\
\hline $\begin{array}{l}\text { Capaian } \\
\text { Pembelajaran }\end{array}$ & : & $\begin{array}{l}\text { Mampu Menguasai konsep korelasi } \\
\text { ibadah dan akhlak dalam hubungan } \\
\text { sosial manusia (muamalah) } \\
\text { sehingga membangun motivasi } \\
\text { ibadah yang bisa menunjukkan } \\
\text { pada perubahan perilaku positif. }\end{array}$ \\
\hline $\begin{array}{l}\text { Kemampuan Akhir } \\
\text { yang diharapkan }\end{array}$ & : & $\begin{array}{l}\text { Memahami hakekat akhlak dalam } \\
\text { keluarga dan larangan kekerasan } \\
\text { dalam rumah tangga }\end{array}$ \\
\hline Alokasi Waktu & : & 100 menit \\
\hline Pertemuan ke- & : & 10 \\
\hline Indikator & & $\begin{array}{l}\text { 10.1 Menjelaskan urgensi keluarga } \\
\text { dalam hidup manusia } \\
\text { 10.2 Memahami akhlak suami istri } \\
\text { 10.3 Menjelaskan akhlak orangtua } \\
\text { terhadap anak } \\
\text { 10.4 Menjelaskan akhlak anak }\end{array}$ \\
\hline
\end{tabular}




\begin{tabular}{|l|l|l|}
\hline & $\begin{array}{l}\text { terhadap Orangtua } \\
10.5 \text { Mempertegas peran akhlak } \\
\text { dalam membangun keluarga } \\
\text { sakinah } \\
\text { 10.6 Memahami larangan kekerasan } \\
\text { dalam rumah tangga }\end{array}$ \\
\hline Materi Pokok & $:$ & $\begin{array}{l}\text { Akhlaq dalam Keluarga dan } \\
\text { Larangan Kekerasan Dalam Rumah } \\
\text { Tangga }\end{array}$ \\
\hline
\end{tabular}

\section{A. Pendahuluan}

Pada bab ini akan dibahas tentang Akhlaq dalam Keluarga dan Larangan Kekerasan dalam Rumah Tangga. Setelah membaca ini, diharapkan mahasiswa mampu memahami pentingnya peran keluarga dalam kehidupan.

\section{B. Penyajian Materi}

\section{Urgensi Keluarga Dalam Hidup Manusia}

Dalam pandangan ilmu sosial, keluarga merupakan golongan masyarakat terkecil yang terdiri atas suami-istri-anak. Pengertian demikian mengandung dimensi hubungan darah dan juga 
hubungan sosial. Dalam hubungan darah keluarga bisa dibedakan menjadi keluarga besar dan keluarga inti, sedangkan dalam dimensi sosial, keluarga merupakan suatu kesatuan sosial yang diikat oleh saling berhubungan atau interaksi dan saling mempengaruhi, sekalipun antara satu dengan lainnya tidak terdapat hubungan darah.

Keluarga menjadi tempat dasar bagi manusia untuk membangun kehidupan yang lebih baik sebelum bersentuhan dengan dunia luar. Sebagaimana teori hierarki kebutuhan yang pernah disampaikan oleh Abraham Maslow (Sarwono:2002) bahwa manusia memiliki kebutuhan yang bersifat hierarki (Hierarchi of Needs) antara lain:

1. Kebutuhan Fisiologis atau dasar

2. Kebutuhan akan Rasa Aman

3. Kebutuhan untuk Dicintai dan Disayangi

4. Kebutuhan untuk Dihargai

5. Kebutuhan untuk Aktualisasi Diri

Lima kebutuhan manusia ini apabila dalam tiap tahapannya dilalui, maka seorang manusia akan menjalani pengalaman hidupnya dengan baik. Di situlah nilai penting sebuah keluarga dengan status 
anggota keluarga yang mampu menjalankan peran dalam pemenuhan kebutuhan sebagaimana dalam teori hierarchi of needs di atas, maka stimulus positif akan memberi dampak positif pula bagi keluarga.

Dampak terbesar akan dirasakan anak-anak selaku anggota keluarga yang paling muda. Di usia mereka keluarga memiliki pengaruh mengantarkan anak-anak untuk memasuki wilayah sosial yang lebih besar, seperti lingkungan sosial. Dalam konteks ini, keluarga menjadi pengatur dan designer anak untuk memilih lingkungan mana yang tepat dan baik dalam menumbuhkan kepribadian. Keluarga bertanggung jawab untuk mengarahkan anak-anaknya memasuki lingkungan sosial yang baik agar anak terhindar dari pengaruh lingkungan yang tidak sehat.

Kepentingan yang besar atas terbentuknya keluarga yang baik berkaitan erat dengan sabda Rasulullah SAW tentang kriteria keluarga ideal:

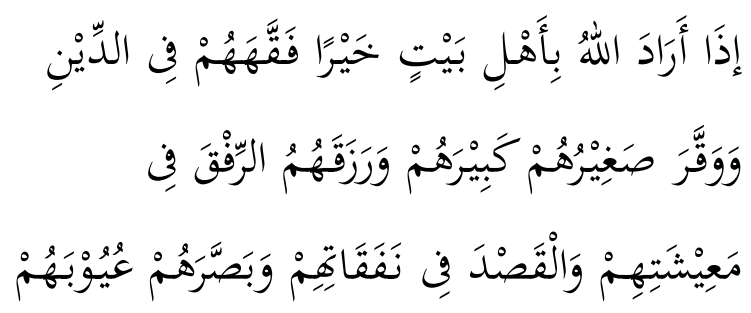




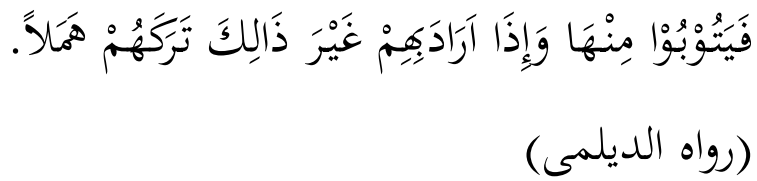

"Apabila Allah menghendaki rumah tangga bahagia, maka diberikan kecenderungan pemahaman ilmu agama. Yang muda menghormati yang tua, harmonis dalam kehidupan, tidak berlebihan dalam memanfaatkan hasil nafkahnya, saling mengoreksi kekurangan mereka dan meminta maaf/melakukan taubat dari kesalahan-kesalahan itu. Dan jika Allah menghendaki sebaliknya, maka ditinggalkannya mereka dalam kesesatan." (HR. ad-Dailamy)

\section{Akhlak Suami Istri}

Komponen dasar dalam suatu keluarga adalah suami dan istri, maka penting untuk diketahui tentang beberapa perilaku yang harus dimiliki oleh suami dan istri, agar rumah tangga yang dibangun menjadi harmonis. Sebuah rumah tangga juga memerlukan tujuan yang ingin dicapai bersama, sehingga rasa kebersamaan itulah yang memadukan perbedaan antara satu sama lain. Berkaitan dengan hal 
ini, maka ada beberapa hal yang harus diperhatikan oleh suami dan istri :

a. Suami isteri hendaknya menumbuhkan suasana mawadah dan rahmah. (QS. Ar-Rum: 21)

b. Hendaknya saling mempercayai dan memahami sifat masing-masing pasangannya. (QS.An-Nisa': 19, QS.Al-Hujarat: 10)

c. Hendaknya saling menghiasi dengan pergaulan yang harmonis. (QS.An-Nisa':19)

d. Hendaknya saling menasehati dalam kebaikan (QS. al-Ashr:4)

Sebagai pemimpin dalam rumah tangga, hal-hal yang harus diperhatikan oleh suami, antara lain:

a. Memberi nafkah lahir dan batin, suami hendaknya menyadari bahwa isteri adalah suatu ujian dalam menjalankan agama. (QS. At-Taubah: 24)

b. Seorang isteri bisa menjadi musuh bagi suami dalam mentaati Allah dan Rasul-Nya. (QS. AtTaghabun: 14) 
c. Hendaknya senantiasa berdo'a kepada Allah meminta isteri yang sholihah. (QS. Al-Furqon: 74)

d. Diantara kewajiban suami terhadap isteri ialah: membayar mahar (QS. An-Nisa:4), memberi nafkah (QS. al-Baqarah:233), Menggaulinya dengan baik (QS. An-Nisa':19).

e. Jika isteri berbuat Nusyuz, ${ }^{189}$ maka dianjurkan melakukan tindakan berikut ini secara berurutan: (1) Memberi nasehat, (2) Pisah kamar, (3) Memukul dengan pukulan tidak menyakitkan. (QS.An-Nisa': 34)

f. Suami tidak boleh kikir dalam menafkahkan hartanya untuk isteri dan anaknya (QS. AthThalaq: 7)

g. Suami wajib selalu memberikan pengertian, bimbingan agama kepada isterinya, dan menyuruhnya untuk selalu taat kepada Allah dan Rasul-Nya. (QS. Al-Ahzab: 34, QS. At-Tahrim: 6)

${ }^{189}$ Nusyuz adalah kedurhakaan isteri kepada suami dalam hal ketaatan kepada Allah. 
h. Suami wajib berlaku adil dan bijaksana terhadap istri. (An-Nisa': 3)

i. Suami tidak boleh membuka aib isteri kepada siapapun. (QS. al-Baqarah:187)

Seorang istri ibarat manajer dalam rumah tangganya. Ia bertanggungjawab atas rumah tangga yang dipimpin suaminya. Sebagaimana hadis Rasulullah SAW:

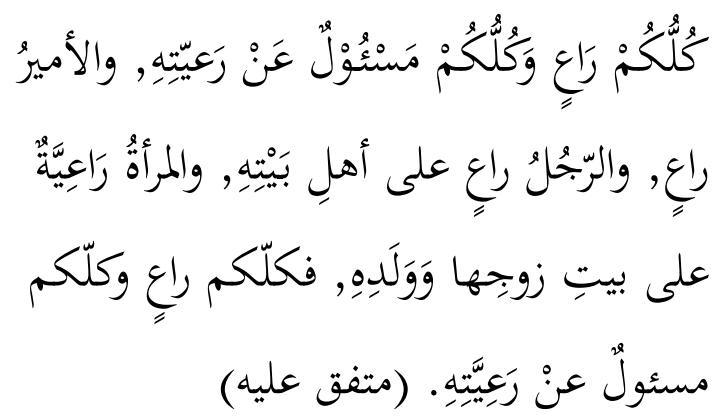

Kalian adalah pemimpin dan kalian akan dimintai pertanggungjawaban atas kepemimpinan kalian. Seorang penguasa adalah pemimpin, seorang suami adalah seorang pemimpin seluruh keluarganya, demikian pula seorang isteri adalah pemimpin atas rumah suami dan anaknya. Kalian adalah pemimpin yang akan dimintai pertanggungtawaban atas kepemimpinan kalian". (Muttafaq 'Alaihi) 
Maka ada banyak hal yang perlu diperhatikan oleh seorang istri, diantaranya:

a. Patuh dan taat pada suami, menghormatinya dalam batas-batas tertentu sesuai dengan ajaran Islam. (HR. al-Tirmidzi)

b. Menghargai usaha atau jerih payah suami dan bahkan membantu suami dalam menyelesaikan kesulitan yang dihadapinya

c. Isteri menyadari dan menerima dengan ikhlas bahwa kaum laki-laki adalah pemimpin wanita. (An-Nisa': 34)

d. Isteri menyadari bahwa hak (kedudukan) suami setingkat lebih tinggi daripada isteri. (Al-Baqarah: 288)

e. Isteri wajib mentaati suaminya selama bukan kemaksiatan. (An-Nisa': 39)

\section{Akhlak Orangtua Terhadap Anak}

Orangtua dan anak mempunyai hubungan yang istimewa satu sama lain. Prof. Dr. Yunahar Ilyas mengklasifikasikan model hubungan yang dibangun antara orangtua dan anak (2012:173): 
a. Hubungan Tanggungjawab

Hubungan ini terbentuk karena anak merupakan amanah yang dititipkan Allah SWT kepada orangtua untuk dibesarkan dan dididik dengan sebaik-baiknya.

b. Hubungan Kasih Sayang

Dikatakan sebagai hubungan kasih sayang karena anak adalah tempat orangtua untuk mencurahkan kasih sayang. Kehidupan sebuah keluarga tidak terasa sempurna tanpa kehadiran seorang anak. Secara fitrah, anak-anak dijadikan oleh Allah sebagai salah satu perhiasan dunia, sebagaimana firman Allah SWT dalam Surah alKahfi (18) ayat 46:

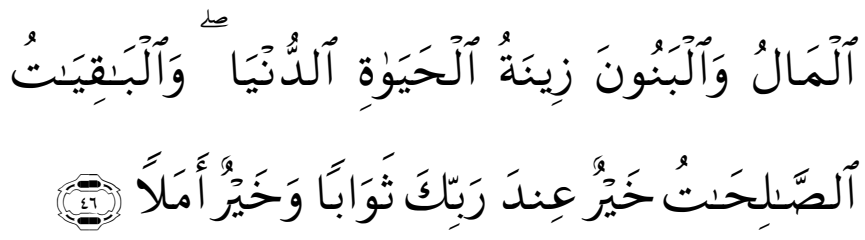

"Harta dan anak-anak adalah perhiasan kehidupan dunia tetapi amalan-amalan yang kekal lagi saleh adalah lebih baik pahalanya di sisi Tuhanmu serta lebih baik untuk menjadi harapan". 
c. Hubungan Masa Depan

Disebut sebagai hubungan masa depan, karena anak-anak yang shalih atau shalihat akan menjadi investasi bagi orangtuanya di akhirat. Karena dari merekalah pahala-pahala kebaikan tetap mengalir kepada orangtua meski telah meninggal dunia. Sebagaimana Sabda Rasulullah SAW:

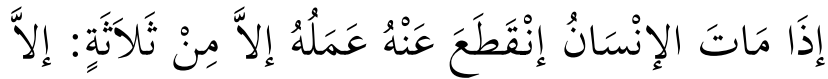

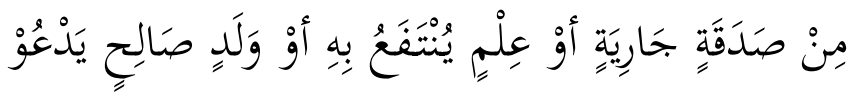

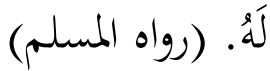

"Jika seseorang meninggal dunia, terputuslah pahala amalannya kecuali salah satu dari tiga hal: Shadaqah Jariyah, Ilmu yang bermanfaat dan anak shalih yang mendoakannya." (HR. Muslim)

Maka dari tiga hubungan yang terjalin itu, orangtua memiliki kewajiban mendampingi anak, membekali mereka secara jiwa dan raga agar mandiri dan memiliki kepribadian shalih/shalihat kelak ketika dewasa. Rasulullah SAW bersabda berkaitan tentang hak anak (BP4 Jatim, t.t.:21): 


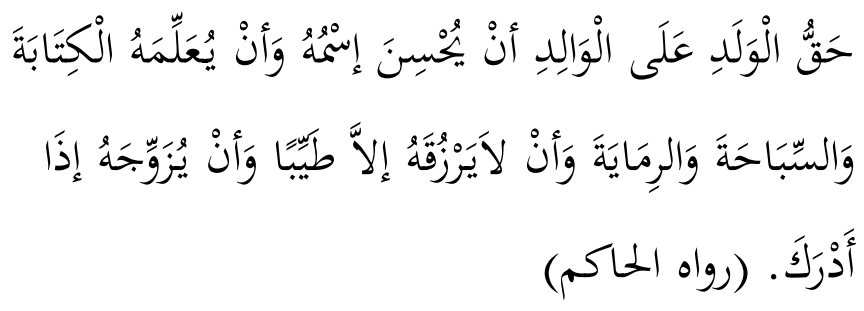

"Kewajiban orangtua terhadap anak ialah memberi nama yang baik, mengajarkan baca tulis, berenang, memanah, memberi nafkah yang halal dan menikahkannya ketika dewasa." (HR. al-Hakim)

Dari hadis di atas dapat difahami tentang kewajiban orangtua terhadap anak diantaranya adalah:

1. Memberi nama yang baik

2. Membekalinya pendidikan formal

3. Melatih kesehatan jasmani (berenang) dan kecerdasannya (memanah)

4. Menafkahi dengan yang halal dan baik

5. Menikahkan ketika telah dewasa.

Apabila diklasifikasikan menurut al-Qur'an, ada empat tipologi anak bagi orangtua: 1). Anak sebagai perhiasan hidup di dunia (QS.18:46), 2). Anak sebagai ujian (QS.8:28), 3). Anak sebagai Musuh (QS. 64:14), 4). Anak sebagai cahaya mata (QS. 28:74). Dengan mengetahui hal tersebut, maka penting untuk 
diketahui bahwa anak shaleh tidak begitu saja dilahirkan, tetapi harus dibentuk dan dibina melalui pendidikan positif yang berkaitan langsung dengan ayah dan ibu selaku orangtuanya dengan melaksanakan segala macam amal ibadah sebagaimana yang telah diajarkan oleh Rasulullah SAW.

\section{Akhlak Anak Terhadap Orangtua}

Dalam Islam, akhlak anak terhadap orangtua lebih dikenal dengan istilah birrulwalidain. Istilah ini berasal dari Rasulullah SAW, sebagaimana dalam riwayat suatu hadis dari Abdullah bin Mas'ud yang bertanya kepada Rasulullah tentang amalan yang paling disukai oleh Allah SWT.

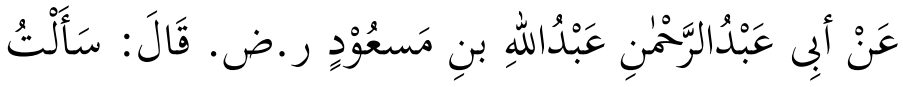

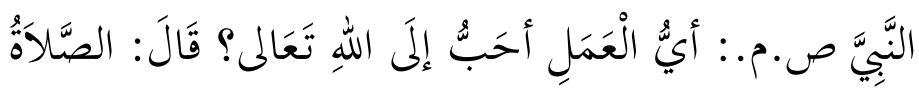

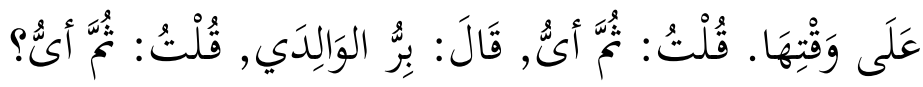

$$
\begin{aligned}
& \text { الإجهَهادُ فِن سَبِيْلِ اللهِهِ (متفق عليه) }
\end{aligned}
$$

"Diriwayatkan dari Abu Abdurrahman Abdullah ibnu Mas'ud RA, dia berkata: Aku bertanya kepada Rasulullah SAW, apa amalan yang paling disukai 
Allah SWT, beliau menjawab: Shalat tepat pada waktunya, aku bertanya lagi: Kemudian apa? Rasulullah menjawab: Birrul Walidain, aku bertanya lagi: Kemudian apa? Beliau menjawab: Jihad fi Sabilillah" Muttafaqun 'alaih.

Birrulwalidain mempunyai makna berbuat baik kepada kedua orangtua. Perintah birrulwalidain ini termasuk perintah yang penting dalam ajaran Islam Karena dalam beberapa ayat al-Qur'an Allah menyandingkan perintah ini setelah perintah tidak menyekutukan Allah. (QS 17:22, 31:14) Kebalikannya adalah 'uququlwalidain yakni mendurhakai orangtua. Istilah tersebut juga merupakan sebutan langsung yang berasal dari Rasulullah SAW ketika menyebutkan dosa-dosa besar, diriwayatkan dalam suatu hadis:

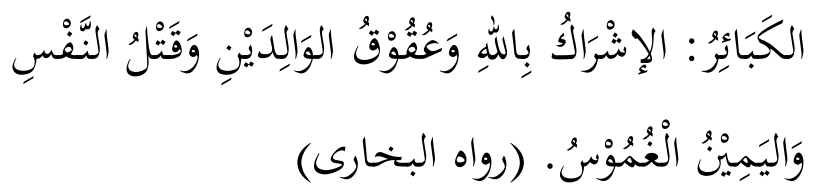

"Dosa-dosa

besar

adalah:

Mempersekutukan Allah, durhaka kepada kedua orangtua, membunuh orang dan sumpah palsu." (HR. al-Bukhary)

Beberapa bentuk birrulwalidain (Ilyas, 2014: 152), antara lain: 
a. Mengikuti keinginan dan saran orangtua dalam berbagai aspek. Selama keinginan dan saran tersebut sesuai dengan ajaran Islam. (QS. Luqman:15)

b. Menghormati dan memuliakan kedua orangtua. (QS. Luqman:14)

c. Membantu orangtua baik secara fisik maupun materiil. (HR. Muslim)

d. Mendoakan orangtua agar diberikan pengampunan, rahmat dan lainnya. (QS. Nuh:28)

e. Apabila orangtua telah meninggal, maka bentuk birrulwalidain yang bisa dilakukan oleh seorang anak adalah: Menyelenggarakan pemakaman jenazah dengan sebaik-baiknya sesuai dengan syariat Islam, Melunasi hutang-hutangnya, Melaksanakan wasiatnya, Meneruskan silaturrahim yang dibinanya ketika hidup, Memuliakan sahabat-sahabatnya, mendoakannya.

\section{Peran Akhlak dalam Membangun Keluarga Sakinah}

Hidup berkeluarga dalam Islam merupakan sunnatullah. Keberadaan status keluarga dalam 
masyarakat pun sudah menjadi suatu institusi yang dilindungi oleh masyarakat dan Negara terlebih lagi oleh agama. Sebagai lembaga masyarakat, keberadaan keluarga yang dibentuk melalui pernikahan, sudah diterima warga dari sejak zaman dahulu kala. Realitas tersebut dapat dilihat dari pengakuan dan perlindungan masyarakat pada keluarga yang dibentuk dari pernikahan. Pada umumnya aturan warga masyarakat terhadap lembaga keluarga bersifat dinamis. Pada awalnya aturan tersebut nampak ketat, kemudian melonggar karena adanya pergeseran nilai dan norma dalam masyarakat (Hadiwardoyo, 1990: 52).

Setiap keluarga yang telah terbangun dalam suatu mahligai rumah tangga tentu tidak berkeinginan mengalami kehancuran. Maka dari sinilah upayaupaya mempertahankan keutuhan rumah tangga perlu dilakukan salah satunya adalah melalui pembiasaan akhlak yang baik. Pentingnya peran akhlak yang baik dalam suatu keluarga menurut al-Ghifari (al-Ghifari, 2003: 49-54) dipengaruhi oleh beberapa sikap: 1). Saling Setia, 2). Saling Terbuka, 3). Tidak Cemburu 
yang berlebihan, 4). Penuh keceriaan dan murah senyum.

Akhlak memiliki peranan yang fundamental bagi suatu keluarga. Apa jadinya sebuah keluarga yang dibangun dari akhlak yang tercela, pasti penuh pertengkaran, tidak harmonis dan pada akhirnya melahirkan generasi yang fasik. Padahal dalam tatanan Islam, melalui keluarga Allah mengajarkan sistem kerjasama antar satu sama lain dalam area terkecil. Sebagaimana dalam firman-Nya Surah alTahrim (66) ayat 6 :

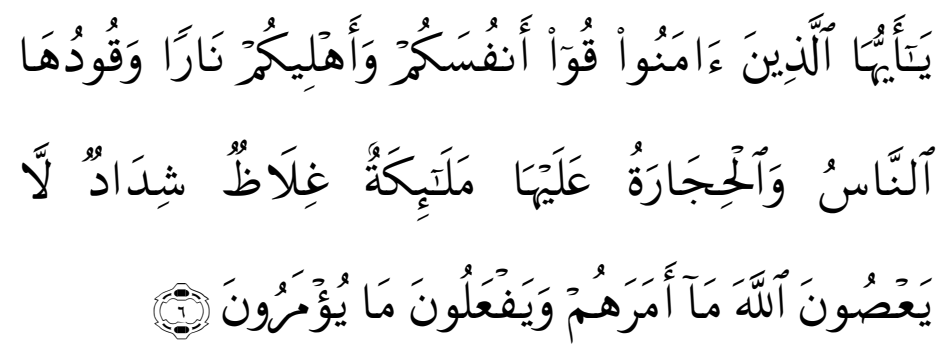

"Hai orang-orang yang beriman, peliharalah dirimu dan keluargamu dari api neraka yang bahan bakarnya adalah manusia dan batu; penjaganya malaikatmalaikat yang kasar, keras, dan tidak mendurhakai Allah terhadap apa yang diperintahkan-Nya kepada mereka dan selalu mengerjakan apa yang diperintahkan."

Sayyid Sabiq menjelaskan maksud dari memelihara diri dan keluarga dalam kandungan ayat 
tersebut di atas, bahwa menjaga diri dan keluarga dari api neraka adalah pendidikan dan pengajaran. Kemudian menumbuhkan mereka agar berakhlak mulia dan menunjukkan mereka kepada hal-hal yang bermanfaat dan membahagiakan mereka (Ilyas, 1997:

12). Dengan kata lain, melalui ayat ini Allah mensyariatkan untuk saling mengingatkan dalam kebaikan dimulai dari wilayah terkecil, yakni keluarga. Suami sebagai kepala rumah tangga memiliki tanggung jawab terbesar dalam hal ini. Namun tidak menutup kemungkinan untuk anggota keluarga yang lain. Karena kewajiban dakwah berlaku pada setiap muslim dan muslimah. Apabila dalam sebuah keluarga diliputi akhlak yang mulia tentu memberikan implikasi baik bagi masyarakat tempat tinggalnya lebih penting keluarga tersebut mendapat ridha Allah SWT.

\section{Larangan Kekerasan dalam Rumah Tangga}

Kekerasan Dalam Rumah Tangga (KDRT) adalah kekerasan yang dilakukan oleh suami-istri atau kekerasan oleh orangtua terhadap anak. KDRT merupakan suatu bentuk pelanggaran hak-hak asasi 
manusia dan kejahatan terhadap kemanusiaan, juga termasuk tindakan diskriminasi. KDRT dalam definisi Hukum dan Ham adalah tindakan yang dilakukan di dalam rumah tangga baik oleh suami, istri maupun anak yang berdampak buruk terhadap keutuhan fisik, psikis dan keharmonisan hubungan sesuai yang termaktub pasal 1 UU No.23 Tahun 2004 tentang Penghapusan Kekerasan dalam Rumah Tangga (www.djpp.depkumham.go.id).

Ruang lingkup tindakan KDRT adalah perbuatan terhadap seseorang terutama perempuan, yang berakibat timbulnya kesengsaraan atau penderitaan secara fisik, seksual, psikologis dan/atau penelantaran rumah tangga termasuk ancaman untuk melakukan perbuatan pemaksaan atau perampasan kemerdekaan secara hukum dalam lingkup rumah tangga. Menurut data Departemen Hukum dan HAM penyebab dari timbulnya KDRT antara lain:

1. Laki-laki dan perempuan tidak dalam posisi setara

2. Anggapan yang berkembang di masyarakat bahwa laki-laki harus mendominasi, kuat dan berani 
3. KDRT tidak dianggap sebagai permasalahan sosial, melainkan permasalahan internal rumah tangga

4. Pemahaman keliru terhadap ajaran agama, sehingga timbul anggapan bahwa laki-laki boleh menguasai perempuan.

Islam dalam masalah pernikahan dan keluarga telah banyak memberikan adab-adab yang harus ditaati oleh suami dan istri. Khususnya ketika terjadi masalah keluarga, Rasulullah telah memberikan pesan kepada para suami untuk hati-hati bersikap kepada istri (Tuasikal, http://rumaysho.com// ), dalam hadis Abu Hurairah ra. Rasululullah bersabda:

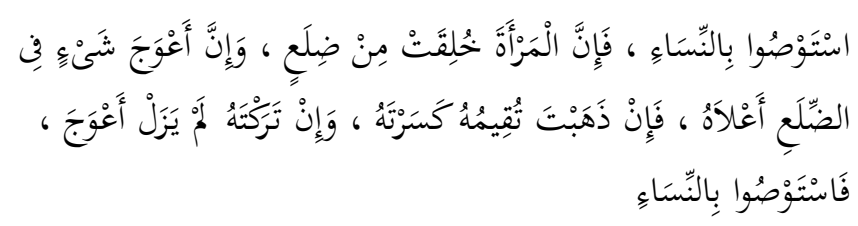

"Berbuat baiklah pada para wanita. Karena wanita diciptakan dari tulang rusuk. Yang namanya tulang rusuk, bagian atasnya itu bengkok. Jika engkau mencoba untuk meluruskannya (dengan kasar), engkau akan mematahkannya. Jika engkau 
membiarkannya, tetap saja tulang tersebut bengkok. Berbuat baiklah pada para wanita." (HR. Bukhari no. 3331 dan Muslim no. 1468).

Al-Qur'an juga telah memberikan pesan yang tidak jauh berbeda dalam Surah an-Nisa' ayat 19:

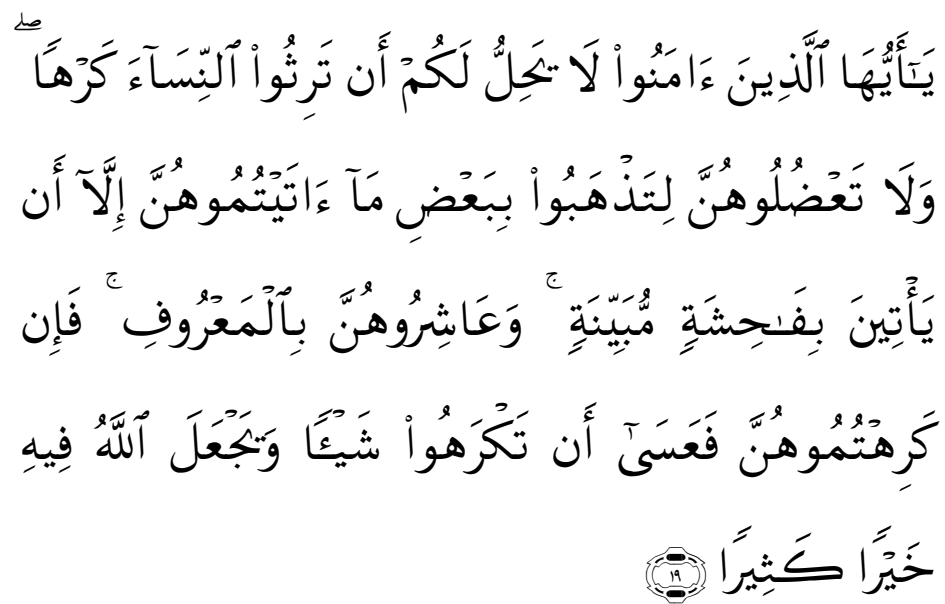

"Hai orang-orang yang beriman, tidak halal bagi kamu mempusakai wanita dengan jalan paksa dan janganlah kamu menyusahkan mereka karena hendak mengambil kembali sebagian dari apa yang telah kamu berikan kepadanya, terkecuali bila mereka melakukan pekerjaan keji yang nyata. dan bergaullah dengan mereka secara patut. kemudian bila kamu tidak menyukai mereka, (maka bersabarlah) karena mungkin kamu tidak menyukai sesuatu, Padahal Allah menjadikan padanya kebaikan yang banyak." 
Ayat tersebut di atas hanyalah bagian kecil dari ayat-ayat Allah yang mengatur perilaku manusia dalam masalah keluarga. Sehingga dapat difahami bahwa Allah benar-benar telah memberikan aturan yang ketat dalam setiap kehidupan manusia, maka semua kembali kepada individunya apakah ia mampu taat atas aturan Allah atau malah mengabaikannya. Wallahu a'lam bi al-Shawab.

\section{Rangkuman}

Ringkasan dari materi di atas antara lain:

1. Keluarga merupakan suatu kesatuan sosial yang diikat oleh saling berhubungan atau interaksi dan saling mempengaruhi, sekalipun antara satu dengan lainnya tidak terdapat hubungan darah. Keluarga menjadi sebuah komunitas penting dalam hidup manusia karena keluarga merupakan tempat dasar bagi manusia untuk membangun kehidupan yang lebih baik sebelum bersentuhan dengan dunia luar.

2. Hal dasar yang berkaitan tentang akhlak suami-istri yang harus diketahui antara lain: a. Suami isteri hendaknya menumbuhkan suasana mawadah dan rahmah. (QS. Ar-Rum: 21); b. Hendaknya saling 
mempercayai dan memahami sifat masing-masing pasangannya. (QS.An-Nisa': 19, QS.Al-Hujarat: 10); c. Hendaknya saling menghiasi dengan pergaulan yang harmonis. (QS.An-Nisa':19); d. Hendaknya saling menasehati dalam kebaikan (QS. al-Ashr:4)

3. Ada banyak hal yang menjadi kewajiban orangtua kepada anak. Diantaranya terdapat dalam hadis yang diriwayatkan oleh al-Hakim, yang bisa disimpulkan sebagai berikut: a. Memberi nama yang baik; b. Membekalinya pendidikan formal; c. Melatih kesehatan jasmani (berenang) dan kecerdasannya (memanah); d. Menafkahi dengan yang halal dan baik; e. Menikahkannya ketika telah dewasa.

4. Akhlak anak terhadap orangtua dalam Islam lebih dikenal dengan istilah birrulwalidain. Adapun bentuk-bentuk birrulwalidain diantaranya: a). Mengikuti keinginan dan saran orangtua dalam berbagai aspek. Selama keinginan dan saran tersebut sesuai dengan ajaran Islam. (QS. Luqman:15); b). Menghormati dan memuliakan kedua orangtua. (QS. Luqman:14); c). Membantu orangtua baik secara fisik maupun materiil. (HR. Muslim); d). Mendoakan orangtua agar diberikan pengampunan, rahmat dan 
lainnya. (QS. Nuh:28); e). Apabila orangtua telah meninggal, maka bentuk birrulwalidain yang bisa dilakukan oleh seorang anak adalah: Menyelenggarakan pemakaman jenazah dengan sebaik-baiknya sesuai dengan syariat Islam, Melunasi hutang-hutangnya, Melaksanakan wasiatnya, Meneruskan silaturrahim yang dibinanya ketika hidup, Memuliakan sahabat-sahabatnya, mendoakannya.

5. Akhlak memberikan pengaruh yang begitu besar bagi terbinanya rumah tangga yang harmonis/sakinah. Pentingnya peran akhlak yang baik dalam suatu keluarga dalam suatu penelitian dipengaruhi oleh beberapa sikap, antara lain: 1). Saling Setia, 2). Saling Terbuka, 3). Tidak Cemburu yang berlebihan, 4). Penuh keceriaan dan murah senyum.

6. Kekerasan Dalam Rumah Tangga atau disingkat KDRT dalam definisi Hukum dan Ham adalah tindakan yang dilakukan di dalam rumah tangga baik oleh suami, istri maupun anak yang berdampak buruk terhadap keutuhan fisik, psikis dan keharmonisan hubungan sesuai yang termaktub pasal 1 UU No.23 Tahun 2004 tentang Penghapusan 
Kekerasan dalam Rumah Tangga. Ruang lingkup tindakan KDRT adalah perbuatan terhadap seseorang terutama perempuan, yang berakibat timbulnya kesengsaraan atau penderitaan secara fisik, seksual, psikologis dan/atau penelantaran rumah tangga termasuk ancaman untuk melakukan perbuatan pemaksaan atau perampasan kemerdekaan secara hukum dalam lingkup rumah tangga.

\section{Latihan/Tugas}

Membuat kelompok diskusi tema keluarga: a. Kasus KDRT b. Nusyuz

\section{Daftar Pustaka}

Sarwono, Sarlito Wirawan. Berkenalan Dengan Aliran-Aliran dan Tokoh-Tokoh Psikologi, (Jakarta: Bulan Bintang)

Ilyas, Yunahar. Kuliah Akhlaq, Cet.Ke-13 (Yogyakarta: LPPI, 2014)

BP4 Jatim, Tuntunan Praktis Rumah Tangga Bahagia, (Surabaya: t.p., t.t.)

Hadiwardoyo, Purwa. Moral dan Masalahnya, (Yogyakarta: Kanisius, 1990) 
al-Ghifari, Abu. Wanita Ideal Dambaan Pria Sejati, (Bandung: Mujahid, 2003)

Ilyas, Asnelly. Mendambakan Anak Saleh; Prinsip-Prinsip Pendidikan Anak Dalam Islam, Cetakan ke-4, (Bandung: AlBayan, 1997)

Depkumham., Upaya Pemenuhan Hak-Hak Korban KDRT, Artikel. http://www.djpp.depkumham.go.id/hukumpidana/653-undang-undang-no-23-tahun-2004 unduh tgl 2408-2016

Tuasikal, M. Abduh. Suami Memukul Wajah Istri, https://rumaysho.com/9483-kdrt-suami-memukul-wajahistri.html diunduh tgl 24-08-2017 


\section{BAB IX}

\section{AKHLAK SOSIAL}

\begin{tabular}{|c|c|c|}
\hline Nama Mata Kuliah & : & $\begin{array}{l}\text { IBADAH, AKHLAK \& } \\
\text { MUAMALAH }\end{array}$ \\
\hline $\begin{array}{l}\text { Capaian } \\
\text { Pembelajaran }\end{array}$ & : & $\begin{array}{l}\text { Mampu Menguasai konsep korelasi } \\
\text { ibadah dan akhlak dalam hubungan } \\
\text { sosial manusia (muamalah) } \\
\text { sehingga membangun motivasi } \\
\text { ibadah yang bisa menunjukkan } \\
\text { pada perubahan perilaku positif. }\end{array}$ \\
\hline $\begin{array}{l}\text { Kemampuan Akhir } \\
\text { yang diharapkan }\end{array}$ & : & $\begin{array}{l}\text { Memahami tentang akhlak sosial } \\
\text { dan pandangan Islam terhadap } \\
\text { beberapa persoalan: kemiskinan, } \\
\text { kebodohan dan pengangguran }\end{array}$ \\
\hline Alokasi Waktu & : & 100 menit \\
\hline Pertemuan ke- & : & 10 \\
\hline Indikator & : & $\begin{array}{l}\text { 11.1 Menguraikan pandangan Islam } \\
\text { tentang kehidupan sosial } \\
\text { 11.2 Menjelaskan tentang } \\
\text { masyarakat dambaan Islam } \\
\text { 11.3 Menelaah toleransi inter dan } \\
\text { antar umat beragama dalam }\end{array}$ \\
\hline
\end{tabular}




\begin{tabular}{|c|c|c|}
\hline & & $\begin{array}{l}\text { Islam } \\
\text { 11.4 Menerapkan prinsip-prinsip } \\
\text { Islam dalam mewujudkan } \\
\text { kesejahteraan sosial } \\
\text { 11.5 Menguraikan pandangan Islam } \\
\text { terhadap beberapa persoalan: } \\
\text { kemiskinan, kebodohan, dan } \\
\text { pengangguran }\end{array}$ \\
\hline Materi Pokok & : & $\begin{array}{l}\text { Akhlaq Sosial dan Pandangan Islam } \\
\text { Terhadap Beberapa Persoalan: } \\
\text { Kemiskinan, Kebodohan dan } \\
\text { Pengangguran. }\end{array}$ \\
\hline
\end{tabular}

\section{A. Pendahuluan}

Pada bab ini akan dibahas tentang Akhlaq Sosial dan Pandangan Islam Terhadap Beberapa Persoalan: Kemiskinan, Kebodohan dan Pengangguran. Diharapkan setelah membaca ini, mahasiswa mampu memahami pandangan Islam dalam masalah akhlaq sosial terutama terhadap tiga persoalan mendasar dalam kehidupan manusia; Kemiskinan, Kebodohan dan Pengangguran. 


\section{B. Penyajian Materi}

\section{Pandangan Islam tentang kehidupan sosial}

Kata sosial berasal dari bahasa latin socius yang berarti segala sesuatu yang lahir, tumbuh dan berkembang dalam kehidupan bersama (Salim, 2002: 34). Istilah kehidupan sosial pada dasarnya merujuk pada salah satu sebutan bagi manusia sebagai makhluk sosial. Teori makhluk sosial pertama kali dikemukakan oleh Aristoteles seorang filosof Yunani yang menyatakan bahwa manusia adalah zoon politicon, artinya makhluk yang mempunyai kemampuan untuk bergaul dan berkumpul. Istilah tersebut juga mengindikasikan bahwa manusia tidak bisa hidup sendiri dan membutuhkan bantuan orang lain. Keadaan ini berkorelasi dengan firman Allah dalam al-Qur'an Surah al-Hujurat ayat 13:

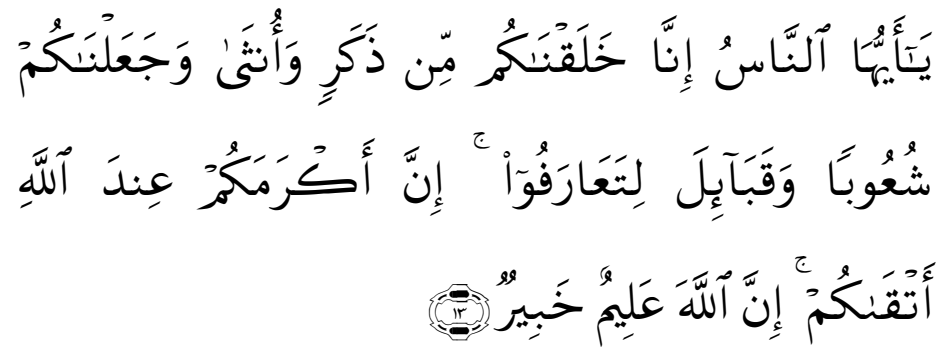

"Hai manusia, Sesungguhnya Kami menciptakan kamu dari seorang laki-laki dan seorang perempuan 
dan menjadikan kamu berbangsa - bangsa dan bersuku-suku supaya kamu saling kenal-mengenal. Sesungguhnya orang yang paling mulia diantara kamu disisi Allah ialah orang yang paling taqwa diantara kamu. Sesungguhnya Allah Maha mengetahui lagi Maha Mengenal".

Kehidupan sosial dalam Islam mencakup pada dua aspek, hablunminannas (interaksi dengan manusia) dan hablunminal'alamin (interaksi dengan alam semesta) yang tertata dalam aturan-aturan yang detail. Kedua aspek ini pada akhirnya berkorelasi dengan Dzat Allah selaku penguasa alam semesta, karena hakikat keimanan disisi Allah salah satunya harus memenuhi unsur kebajikan (perbuatan baik). ${ }^{190}$ Rasulullah SAW dalam salah satu hadis pernah berpesan tentang berbuat baik:

$$
\begin{aligned}
& \text { عَنْ أَبِي هُرَيْرَة رَضِيَ اللهُ عَنْهُ قَالَ : قَالَ رَسُوْلُ اللهِ صلى الله }
\end{aligned}
$$

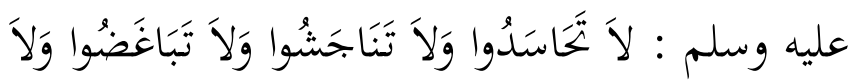

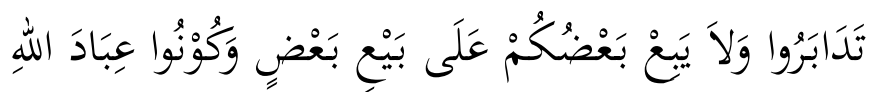

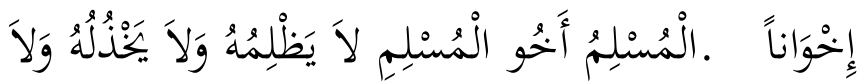

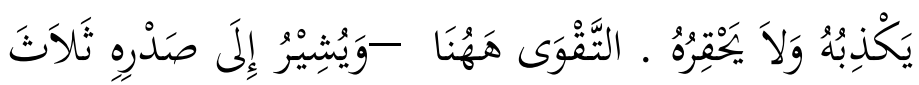

${ }^{190}$ QS. al-Baqarah (2) : 177 


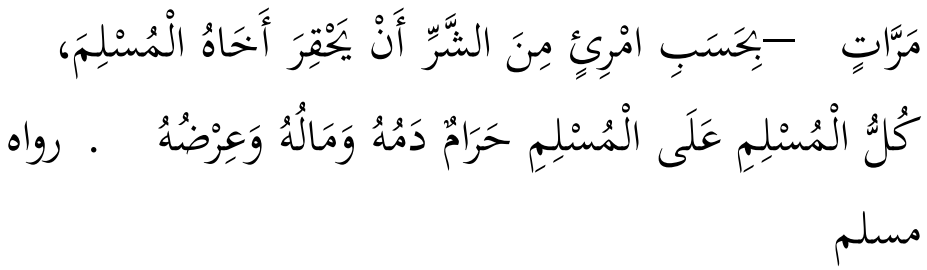

Dari Abu Hurairah radhiallahu 'anhu, ia berkata : "Rasulullah Shallallahu 'alaihi wa Sallam bersabda : "Kamu sekalian, satu sama lain Janganlah saling mendengki, saling menipu, saling membenci, saling menjauhi dan janganlah membeli barang yang sedang ditawar orang lain. Dan jadilah kamu sekalian hambahamba Allah yang bersaudara. Seorang muslim itu adalah saudara bagi muslim yang lain, maka tidak boleh menzhaliminya, menelantarkannya, mendustainya dan menghinakannya. Taqwa itu ada di sini (seraya menunjuk dada beliau tiga kali). Seseorang telah dikatakan berbuat jahat jika ia menghina saudaranya sesama muslim. Setiap muslim haram darahnya bagi muslim yang lain, demikian juga harta dan kehormatannya”. [HR. Muslim]

Islam mengajarkan bahwa dalam kehidupan ini tidak ada kebebasan tanpa batas (Hamka, 2016: 62). Allah menganugerahkan akal fikiran kepada manusia sebagai bekal dalam rangka melaksanakan misi kekhalifahan di bumi agar dengan segala fasilitas yang diberikan Allah, manusia mampu mengelola bumi dengan baik. 


\section{Masyarakat dambaan Islam}

Sejarah peradaban Islam dengan golden age-nya ${ }^{191}$ telah membuktikan bahwa Islam mampu mendirikan suatu peradaban yang luhur. Faktor yang paling menentukan kualitas masyarakat Islam di masa itu adalah keimanan dan keilmuan yang berkembang dinamis. Umat Islam sebagai masyarakat yang mendominasi di wilayahnya mampu hidup berdampingan dengan baik bersama non Muslim dzimmi.

Menurut Dr. Asep Zaenal Ausop, M.Ag (Ausop, 2014: 495) Rasulullah melalui petunjuk Allah mencontohkan bahwa pembangunan masyarakat bukan dimulai dari pembangunan fisik material, sistematika pembangunannya sebagai berikut:

a. Budaya Wahyu, yakni proses penanaman keimanan yang mendalam kepada masyarakat,

191 Golden age of Islam adalah masa kejayaan peradaban Islam \pm berlangsung antara Th. 750 M. s.d. Th. 1258 M. dalam sejarah dunia Barat masa tersebut adalah periode Dark Age (masa kegelapan) karena keadaan yang begitu kontradiktif dengan peradaban Islam yang begitu maju dan peradaban Barat yang kelam dan kumuh (As-Siba'i, Ebook, hal.5) 
nilai keimanan dan ketauhidan yang benar sesuai dengan wahyu Allah.

b. Budaya Normatif, adalah pengenalan tentang norma-norma dan nilai, hukum atau syariah.

c. Budaya Simbolis, pada tahapan ini Rasulullah SAW mulai mengenalkan tentang simbol-simbol keislaman, misalnya dalam ibadah haji ada thawaf, mencium hajar aswad, dll.

d. Budaya Sosial, merupakan pengenalan Rasulullah SAW tentang hubungan sosial kemasyarakatan. Rasulullah SAW mulai berinteraksi dengan dunia luar; internasional. Hubungan antar umat manusia dalam jangkauan yang lebih luas dibangun setelah masyarakat memahami dan mengamalkan norma dan nilai-nilai etika Islam yang harus dijunjung tinggi.

e. Budaya Material, merupakan tahapan paling akhir yakni pembangunan infrastruktur seperti jalan, gedung dan jembatan.

Hasil dari tahapan pembangunan masyarakat yang diterapkan Rasulullah ini membentuk suatu komunitas masyarakat ideal dambaan umat Islam yang memiliki beberapa 
karakteristik kuat, antara lain: a). Tasammuh (bersikap toleran), b). Supremasi Hukum, c). Kesataraan di hadapan hukum, d). Ketahanan dan keamanan Negara dipikul bersama, e). Amar ma'ruf nahi munkar, f). alTawazun (keseimbangan), g). menjunjung tinggi kejujuran, h). 'Adalah (Berkeadilan), i). Rahmah wa Ta'awun (penuh kasih sayang dan saling tolong menolong, j). Taushiyah (menghidupkan kritik yang membangun).

\section{Toleransi inter dan antar umat beragama dalam}

\section{Islam}

Toleransi dalam Kamus Besar Bahasa Indonesia berasal dari kata toleran yang berarti bersifat atau bersikap menenggang (menghargai, membiarkan, membolehkan) pendirian (pendapat, pandangan, kepercayaan dan sebagainya) yang berbeda dan atau yang bertentangan dengan pendiriannya (http://kbbi.web.id/toleran). Dalam bahasa Arab dikenal dengan istilah tasammuh yang bermakna ampun, maaf dan lapang dada (Munawwir, 1984: 1098). 
Secara terminologi, toleransi menurut Umar Hasyim yaitu pemberian kebebasan kepada sesama manusia atau kepada sesama masyarakat untuk menjalankan keyakinannya atau mengatur hidupnya dan menentukan nasibnya masing-masing, selama dalam menjalankan dan menentukan itu tidak melanggar dan tidak bertentangan dengan syaratsyarat atas terciptanya ketertiban dan perdamaian dalam masyarakat (Hasyim, 1979:22).

Berkaitan dengan toleransi di Negara Indonesia terdapat konsep tentang Tri Kerukunan Umat Beragama yang diupayakan oleh pemerintah Indonesia untuk menghidupkan nuansa kerukunan diantara umat beragama yang ada di Indonesia. Isi dari Tri Kerukunan Beragama adalah: 1). Kerukunan intern umat beragama, 2). Kerukunan antar umat beragama, 3). Kerukunan antar umat beragama dan pemerintah.

Dalam realisasinya point pertama dan kedua lah yang seringkali dirasa masih menimbulkan sensitifitas yang tinggi. 
a. Toleransi Intern Umat Beragama

Toleransi intern umat beragama dalam Islam secara teoritis telah ditegaskan Allah di dalam al-Qur'an bahwa hubungan sesama umat Islam adalah bersaudara, dalam surah al-Hujurat ayat 10-12 Allah berfirman:

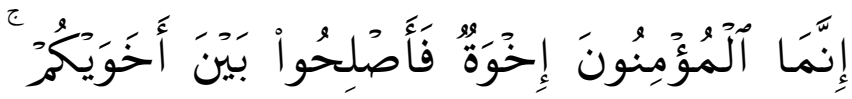

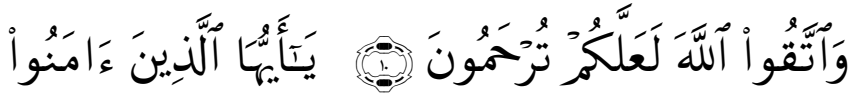

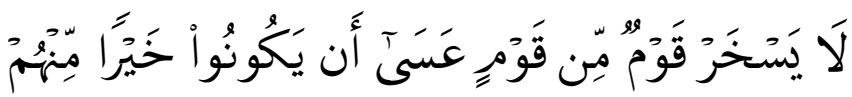

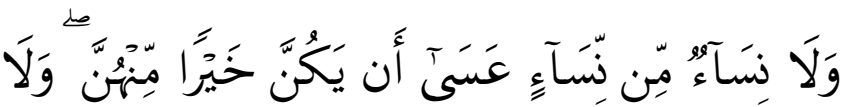

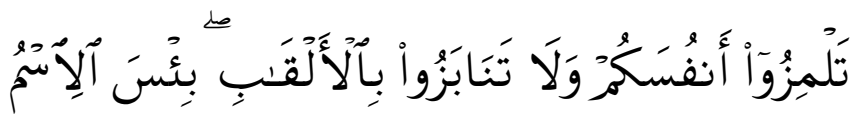

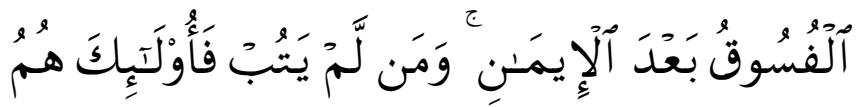

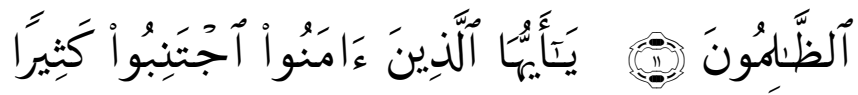

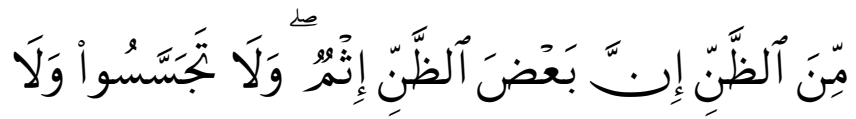

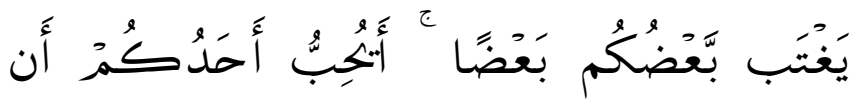




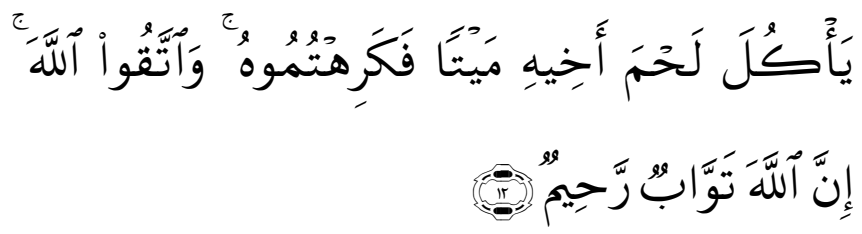

10. Orang-orang beriman itu Sesungguhnya bersaudara. sebab itu damaikanlah (perbaikilah hubungan) antara kedua saudaramu itu dan takutlah terhadap Allah, supaya kamu mendapat rahmat.

11. Hai orang-orang yang beriman, janganlah sekumpulan orang laki-laki merendahkan kumpulan yang lain, boleh Jadi yang ditertawakan itu lebih baik dari mereka. dan jangan pula sekumpulan perempuan merendahkan kumpulan lainnya, boleh Jadi yang direndahkan itu lebih baik. dan janganlah suka mencela dirimu sendiri dan jangan memanggil dengan gelaran yang mengandung ejekan. seburuk-buruk panggilan adalah (panggilan) yang buruk sesudah iman dan Barangsiapa yang tidak bertobat, Maka mereka Itulah orang-orang yang zalim.

12. Hai orang-orang yang beriman, jauhilah kebanyakan purba-sangka (kecurigaan), karena sebagian dari purba-sangka itu dosa. dan janganlah mencari-cari keburukan orang dan janganlah menggunjingkan satu sama lain. Adakah seorang diantara kamu yang suka memakan daging saudaranya yang sudah mati? Maka tentulah kamu merasa jijik kepadanya. dan bertakwalah kepada Allah. Sesungguhnya Allah Maha Penerima taubat lagi Maha Penyayang. 
Allah dalam ayat di atas menjelaskan secara detail apa yang tidak boleh dilakukan seorang muslim kepada saudara muslimnya yang lain. Nampak terinci karena hal ini begitu penting untuk dilaksanakan oleh setiap muslim demi menjaga jalinan persaudaraannya dengan saudara sesama muslimnya. Ini menjadi salah satu bukti universalitas Islam sebagai agama rahmatan lil'alamin. Allah mengetahui di sisi mana sajakah manusia sering lalai dan tidak peduli. Bahkan dalam hadis pun banyak sekali aturan-aturan yang disampaikan Rasulullah terkait dengan hubungan ukhuwwah islamiyah.

b. Toleransi Antar Umat Beragama

Konsep toleransi yang harus difahami di dalam Islam sebagaimana yang tercantum dalam Surah al-Kafirun ayat 6 :

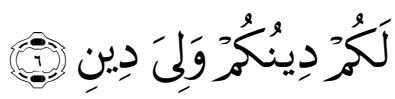

Untukmu agamamu, dan untukkulah, agamaku.

Ibnu Qayyim dalam Bada'i Fawaid 1/248 merujuk pada peristiwa penyebab turunnya 
ayat menyimpulkan bahwa ayat tersebut merupakan isyarat Allah kepada Nabi Muhammad (di masa sekarang umat Islam- red.) untuk berlepas dari pemahaman yang salah atas konsep ketuhanan yang dimiliki oleh umat Non Muslim (As-Sidawi, Ebook).

Diceritakan dalam asbab al-Nuzul dari Surah al-Kafirun bahwa orang-orang Quraisy merayu Rasulullah SAW dengan memperlihatkan harta berlimpah sehingga menjadi orang terkaya di Makkah serta memberinya wanita mana saja yang beliau inginkan. Mereka berkata, "Semua ini untukmu wahai Muhammad, asalkan engkau berhenti menghina tuhan-tuhan kami dan berhenti mengucapkan kata-kata buruk terhadap mereka. Tetapi jika engkau keberatan, bagaimana apabila engkau menyembah tuhan kami selama satu tahun saja" ${ }^{\text {,192 }}$, mendengar tawaran orang-orang Quraisy itu, Rasulullah lalu menjawab, "Saya akan

192 Dalam riwayat lain diceritakan, mereka mengatakan "Wahai Muhammad, mari menyembah tuhan yang kami sembah dan sebagai balasannya kami juga akan menyembah Tuhan yang engkau sembah. Selanjutnya, kami juga akan mengikutsertakan engkau dalam seluruh urusan kami”. 
menunggu hingga Allah memberikan jawabannya" lalu Allah menurunkan surah ini dari awal hingga akhir (as-Suyuthi, 2009: 645).

Ada banyak uswah melalui hadis-hadis yang dicontohkan Rasulullah dalam menghormati hak-hak non-Muslim terhadap masalah muamalah duniawi. Selain itu Rasulullah juga mengajarkan untuk tidak mendzalimi mereka selama mereka juga tidak mendzalimi hak seorang Muslim. Dalam hadis yang diriwayatkan Abu Dawud, Rasulullah bersabda:

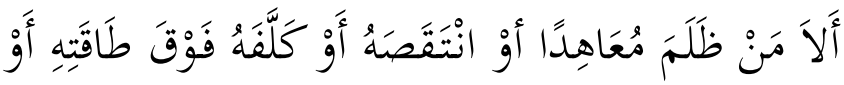

$$
\begin{aligned}
& \text { أَخَذَ مِنْهُ شَيَاً بِغَغْرِ طِيْبِ نَفْسِ فَأَنَا حَجِيْجُجهُ يَوْمَ } \\
& \text { القِيَامَةِة. رواه أبو داود }
\end{aligned}
$$

"Siapa menganiaya seorang dzimmi, atau mengurangi haknya, atau membebaninya melampaui kekuatannya atau mengambil sesuatu darinya tanpa kerelaan hatinya maka aku (Nabi SAW) musuhnya di hari kiamat" (Husna, 2006: 64). 


\section{Prinsip-prinsip Islam dalam mewujudkan kesejahteraan sosial}

Pada dasarnya dalam pandangan sosial, manusia diciptakan Allah dalam kondisi merdeka, tidak tunduk kepada siapapun kecuali hanya kepada Allah SWT. tetapi keberadaannya sebagai anggota masyarakat tentu tidak bisa dilepaskan dari individu atau kelompok lain.

Membicarakan tentang kesejahteraan sosial sangat erat kaitannya dengan keadilan sosial. Karena konsep kesejahteraan sosial tidak akan bisa tercapai tanpa adanya keadilan sosial. Islam sangat peduli dengan permasalahan yang berkaitan dengan kesejahteraan sosial, dalam masalah ekonomi saja Islam mengatur distribusi kekayaan agar tidak beredar di kalangan orang kaya saja (QS.59:7). Bentuk aksi nyata dari kepedulian sosial dalam Islam ini adalah tercermin dari system zakat. Bisa dikatakan zakat merupakan ibadah yang bermuatan ritual dan sosial (Ana, http://naghata.blogspot.co.id/ ). Program ritual karena zakat menjadi suatu ibadah yang mengungkapkan rasa syukur atas rizki dan karunia yang telah diberikan Allah kepada hambaNya, dan 
dikatakan program sosial karena melalui zakat Islam mengatur pendistribusian harta secara merata kepada pihak-pihak yang masuk dalam definisi penerima zakat.

Menurut UU Republik Indonesia No.11 Tahun 2011 Tentang Kesejahteraan Sosial, kesejahteraan sosial adalah kondisi terpenuhinya kebutuhan material, spiritual dan sosial warga Negara agar dapat hidup layak dan mampu mengembangkan diri, sehingga dapat melaksanakan fungsi sosialnya.

Kesejahteraan sosial akan memenuhi tingkat stabilitas nasional, apabila masyarakat memegang beberapa prinsip hidup sosial (PHI, 2009: 71), diantaranya:

a. Menjunjung tinggi nilai kehormatan manusia (QS. al-Isra'[17]:70)

b. Memupuk rasa persaudaraan dan kesatuan manusia (QS.al-Hujurat [49]:13 )

c. Mewujudkan kerjasama umat manusia menuju masyarakat sejahtera lahir batin (QS.al-Maidah [5]:2)

d. Memupuk jiwa toleransi (QS. Fushilat [41]:34) 
e. Menghormati kebebasan orang lain (QS.alBaqarah [2]:256; QS.an-Nisa'[4]:29; QS. al-Balad [90]:13)

f. Menegakkan budi baik (QS.al-Qalam [68]:4)

g. Menegakkan amanat dan keadilan (QS.An-Nisa [4]:57-58)

h. Perlakuan yang sama (QS.al-Baqarah [2]:194)

i. Menepati janji (QS.al-Isra'[17]:34)

j. Menanamkan kasih sayang dan mencegah kemungkaran (QS.al-Hasyr [59]:9)

k. Menjadikan masyarakat komunitas yang shalih dan utama (QS. Ali Imran [3]:114)

1. Berusaha untuk menyatu/bermanfaat dengan masyarakat (QS.al-Maidah [5]:2)

m. Tidak berprasangka buruk kepada sesama (QS.anNur [24]:4)

n. Peduli kepada kaum miskin dan anak yatim (QS.al-Baqarah)

o. Kompetitif dalam hal kebaikan (QS.al-Baqarah [2]:148) 


\section{Pandangan Islam terhadap beberapa persoalan:}

\section{kemiskinan, kebodohan, dan pengangguran}

Kemiskinan, kebodohan dan pengangguran merupakan permasalahan krusial yang melanda hampir di setiap Negara. Islam pun memberikan pandangan tersendiri tentang tiga persoalan sosial ini.

a. Kemiskinan

Dalam pandangan Islam, kemiskinan disebabkan oleh beberapa faktor, diantaranya karena keterbatasan untuk berusaha (QS. AlBaqarah [2]:273), penindasan (QS. Al-Hasyr [59]:8), cobaan Tuhan (QS. Al-An'am[6]:42) dan pelanggaran terhadap hukum-hukum Allah (QS. Al-Baqarah [2]:61). Di sisi lain, kemiskinan pada dasarnya merupakan sunnatullah, sebagaimana ada kondisi sakit dan sehat, ada marah dan sabar, maka ada kaya dan miskin.

Melihat dari beberapa faktor yang telah di uraikan di atas, maka penanggulangan kemiskinan bisa dilakukan pada dua jalan, yakni internal dan eksternal:

a.1 Jalan Internal yakni usaha yang maksimal dari si miskin untuk mempertahankan hidup 
(QS.9:105), berusaha untuk tidak meminta (HR. al-Bukhary) dengan tetap bersabar dan istiqomah mendekatkan diri kepada Allah (QS.2:45) serta tetap berusaha untuk melakukan kebaikan sesuai dengan kemampuannya.

a.2 Jalan Eksternal yakni distribusi bantuan dari kaum yang mampu kepada yang kekurangan melalui zakat, infaq, shadaqah, wakaf, hadiah, dsb. Operasional dari kegiatan ini telah diterangkan secara detail dalam alQur'an. hal ini merupakan pengajaran Islam agar seorang muslim peduli dengan nasib muslim lainnya. Rasulullah SAW bersabda:

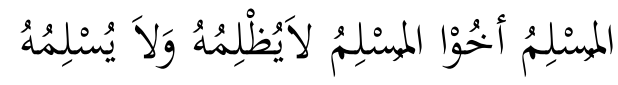

"Seorang Muslim adalah saudara bagi Muslim lainnya, maka dari itu janganlah ia membiarkan terlantar" (HR. al-Bukhary)

b. Kebodohan

Kriteria bodoh di dalam Islam tidak ditentukan dari kecerdasan berfikir an sich, akan tetapi lebih dilihat dari cara pandang seorang manusia dalam mengedepankan persoalan agama. 
Dalam suatu hadis riwayat Ibnu Umar RA, ia berkata: "Suatu hari aku duduk bersama Rasulullah SAW, tiba-tiba datang seorang lakilaki dari kalangan Anshar, kemudian ia mengucapkan salam kepada Nabi SAW dan bertanya: Wahai Rasulullah, siapakah orang mukmin yang paling utama?, Rasulullah SAW menjawab: Yang paling baik akhlaqnya. Kemudian ia bertanya lagi: Siapakah orang mukmin yang paling pintar?, Beliau menjawab: Yang paling banyak mengingat mati, kemudian yang paling baik dalam mempersiapkan kematian tersebut, itulah orang yang paling cerdas." (HR. Ibnu Majjah, Thabrani dan al-Haitsamy). Dalam riwayat lain, Rasulullah SAW bersabda: "Orang yang cerdas adalah orang yang mampu menundukkan hawa nafsunya serta biasa beramal untuk bekal kehidupan setelah mati. Sebaliknya, orang yang lemah adalah orang yang memperturutkan hawa nafsunya, sementara dia berangan-angan kepada Allah" (HR. Ibnu Majjah)

Virus kebodohan yang melanda umat Islam saat ini adalah ketidakpedulian untuk 
mengamalkan al-Qur'an dan as-Sunnah serta lebih mengedepankan rasionalitas dalam berfikir, sehingga persoalan agama yang bersifat ta'abudy seringkali dimaknai dengan cara yang sesuai dengan pemikiran individu. Islam mengakui bahwa kebodohan merupakan akar dari kesesatan. Rasulullah SAW telah memprediksi tentang suatu keadaan di masa akhir zaman, di masa itu Allah menarik ilmu dari bumi dengan cara mewafatkan ulama. Hadis Abdullah bin Amru, Rasulullah SAW bersabda:

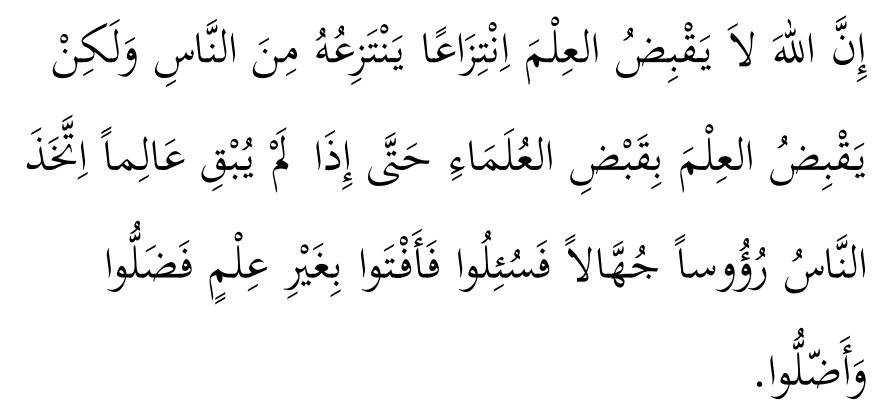

"Sesungguhnya Allah tidak mencabut ilmu dari manusia secara langsung. Akan tetapi Dia mencabut ilmu dengan mewafatkan ulama, orangorang mengangkat para pemimpin yang bodoh, mereka ditanya lalu mereka berfatwa tanpa ilmu, akibatnya mereka sesat dan menyesatkan. " (Muttafaq 'alaih). 


\section{c. Pengangguran}

Pada dasarnya bekerja merupakan hak setiap individu. Mayoritas faktor yang menghendaki seseorang untuk bekerja adalah karena gaji atau upah yang diterima, sedangkan dalam Islam selain karena materi seorang Muslim juga harus mempertimbangkan beberapa faktor yang diajarkan oleh agama. Allah menyatakan dalam al-Qur'an telah menjamin rizki tiap makhluk-Nya, dalam QS. Hud [11]:6:

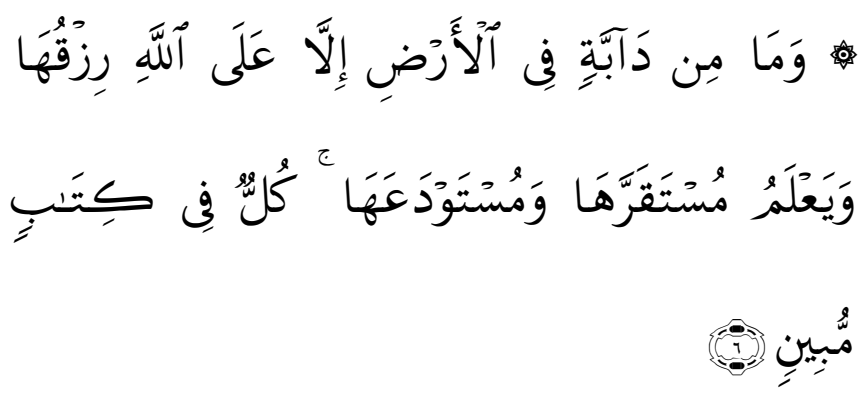

"Dan tidak ada suatu binatang melata ${ }^{193}$ pun di bumi melainkan Allah-lah yang memberi rezkinya, dan Dia mengetahui tempat berdiam

${ }^{193}$ Yang dimaksud binatang melata di sini ialah segenap makhluk Allah yang bernyawa. (al-Qur'an, 2005) 
binatang itu dan tempat penyimpanannya ${ }^{194}$. semuanya tertulis dalam kitab yang nyata (Lauh Mahfuzh)".

Walaupun ayat di atas menerangkan tentang jaminan Allah atas rizki penduduk bumi, namun dalam ayat-ayat lain Allah SWT juga menghendaki manusia untuk berusaha mendapatkan rizkinya dengan cara yang halal. Allah SWT mengajarkan kepada manusia agar hidup dinamis, dan tidak statis; selalu berikhtiar dan berdoa tidak bermalas-malasan dan berpasrah. Allah SWT berfirman:

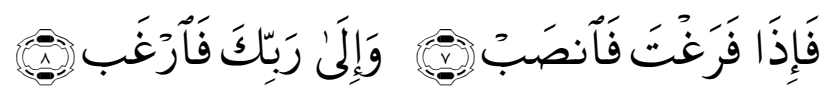

"Maka apabila kamu telah selesai (dari sesuatu urusan), kerjakanlah dengan sungguh-sungguh (urusan) yang lain. Dan hanya kepada Tuhanmulah hendaknya kamu berharap".

Ayat di atas memotivasi manusia untuk tidak bermalas-malasan dan bersungguh-sungguh

${ }^{194}$ Menurut sebagian ahli tafsir yang dimaksud dengan tempat berdiam di sini ialah dunia dan tempat penyimpanan ialah akhirat. dan menurut sebagian ahli tafsir yang lain maksud tempat berdiam ialah tulang sulbi dan tempat penyimpanan ialah rahim. (al-Qur'an, 2005) 
dalam melaksanakan suatu urusan. Motivasi lain ada dalam QS. ar-Ra'd [13] ayat 11:

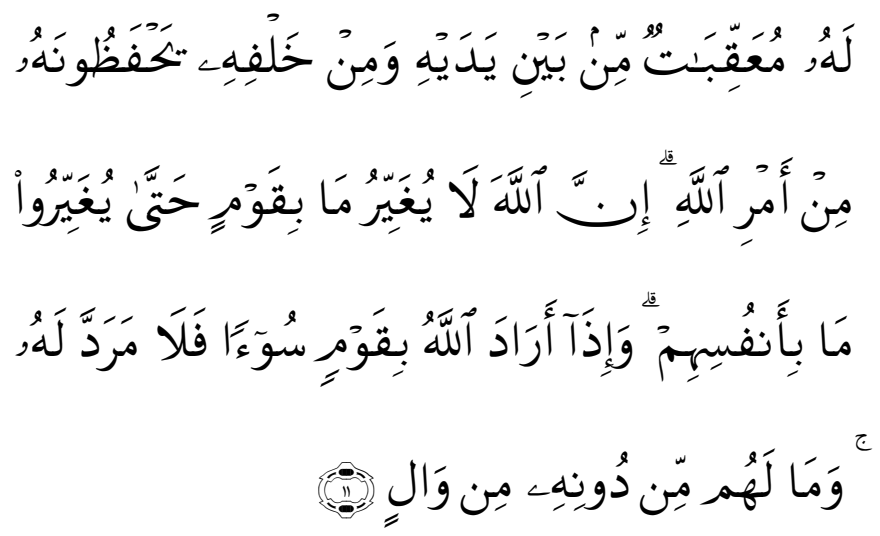

"Bagi manusia ada malaikat-malaikat yang selalu mengikutinya bergiliran, di muka dan di belakangnya, mereka menjaganya atas perintah Allah. Sesungguhnya Allah tidak merobah Keadaan sesuatu kaum sehingga mereka merobah keadaan yang ada pada diri mereka sendiri. dan apabila Allah menghendaki keburukan terhadap sesuatu kaum, Maka tak ada yang dapat menolaknya; dan sekali-kali tak ada pelindung bagi mereka selain Dia".

Ayat di atas mengandung pengertian bahwa segala sesuatu yang terjadi di muka bumi ini adalah atas kehendak Allah, akan tetapi Allah memberikan kesempatan bagi hamba-hamba 
Allah yang menjalankan syariat dan sunnahsunnahNya sebelum berlaku ketentuanNya, karena apabila ketentuan itu sudah berlaku tidak akan ada yang mampu menolaknya.

\section{Rangkuman}

Kesimpulan dari uraian materi di atas, antara lain:

1. Kehidupan sosial dalam Islam mencakup pada dua aspek, hablunminannas (interaksi dengan manusia) dan hablunminal'alamin (interaksi dengan alam semesta) yang tertata dalam aturan-aturan yang detail. Kedua aspek ini pada akhirnya berkorelasi dengan Dzat Allah selaku penguasa alam semesta, karena hakikat keimanan disisi Allah salah satunya harus memenuhi unsur kebajikan (perbuatan baik).

2. Untuk mendapatkan suatu komunitas masyarakat yang ideal dalam Islam, selayaknya perlu melihat cara Nabi SAW ketika mendirikan peradaban Islam pertama kali yang terbangun dengan karakter kuat. Ada 5 tahapan budaya yang beliau terapkan pada masyarakat Arab kala itu, yakni: 1). Budaya Wahyu, 2). Budaya Normatif, 3). Budaya Simbolis, 4). Budaya Sosial, 5). Budaya Material. 
3. Toleransi umat beragama dalam internal umat Islam secara teoritis telah ditegaskan Allah di dalam alQur'an dengan detail bahwa hubungan sesama umat Islam adalah bersaudara (QS. al-Hujurat: 10-12). Demikian pula toleransi antar umat beragama juga telah begitu jelas dalam al-Qur'an maupun asSunnah. Batasan yang jelas nampak pada QS. alKafirun yang mengindikasikan bahwa ada batasan bagi umat Islam dalam mengamalkan toleransi beragamanya pada masalah muamalah duniawi saja.

4. Ada banyak cara dalam menerapkan prinsip hidup Islami untuk mencapai kesejahteraan sosial, diantaranya: Menjunjung tinggi nilai kehormatan manusia (QS. al-Isra'[17]:70); Memupuk rasa persaudaraan dan kesatuan manusia (QS.al-Hujurat [49]:13); Mewujudkan kerjasama umat manusia menuju masyarakat sejahtera lahir batin (QS.alMaidah [5]:2); Memupuk jiwa toleransi (QS. Fushilat [41]:34); Menghormati kebebasan orang lain (QS.alBaqarah [2]:256; QS.an-Nisa'[4]:29; QS. al-Balad [90]:13), dsb.

5. Kemiskinan, kebodohan dan pengangguran nampak sebagai permasalahan sosial yang tidak ada kaitannya 
dengan agama. Tetapi sekali lagi Islam dengan segala ajarannya mengaitkan tiga permasalahan ini dengan spirit keagamaan, bahwa Allah SWT selalu memberikan solusi dan motivasi untuk setiap keadaan, hanya saja kembali kepada manusia, ke arah mana dia mencari solusi. Wallahu a 'lam.

\section{Latihan/Tugas/Eksperimen}

\section{Jawablah pertanyaan di bawah ini:}

1. Bagaimana pandangan Islam tentang kehidupan sosial?

2. Tulislah maks. 5 dalil al-Qur'an ataupun as-Sunnah yang berkaitan dengan toleransi intern umat beragama!

3. Berikan pandangan kalian tentang Islam dan Kebodohan!

\section{Daftar Pustaka}

Salim, A. Perubahan Sosial, (Yogyakarta: Tiara Wacana Yogya, 2002)

Hamka, Pandangan Hidup Muslim, Cet. Ke-1, (Jakarta: Gema Insani Press, 2016) 
as-Siba'i, Mustafa. Peradaban Islam, Ebook diunduh tgl 2408-2017

Ausop, Asep Zaenal. Islamic Character Building; Membangun Insan Kamil, Cendekia, Berakhlak Qur'ani, Cet. Ke-1, (Bandung: Salamadani, 2014)

http://kbbi.web.id/toleran diunduh tgl 25-07-2017

Hasyim, Umar. Toleransi dan Kemerdekaan Beragama dalam Islam sebagai Dasar menuju Dialog dan Kerukunan Antar Umat Beragama, (Surabaya: Bina Ilmu, 1979)

As-Sidawi, Abu Ubaidah Yusuf. 10 Faedah Tentang Aqidah, Ebook http://www.ibnumajjah.wordpress.com/ diunduh tgl 25-08-2017

as-Suyuthi, Jalaluddin. Asbabun Nuzul; Sebab Turunnya Ayat al-Qur'an, Terj. Tim Abdul Hayyie, Cet. Ke-2, (Jakarta: Gema Insani Press, 2009)

Husna, Khotimatul. dkk. 40 Hadits Sahih; Pedoman Membangun Toleransi, Cet. Ke-1, (Yogyakarta: Pustaka Pesantren, 2006)

Nur Rosihin Ana, Konsep al-Qur'an Tentang Kesejahteraan Sosial, http://naghata.blogspot.co.id/2009/02/kesejahteraansosial-dalam-islam.html di unduh tgl 24-08-2017

Departemen Agama RI. Al-Qur'an dan Terjemahnya, Jakarta:

CV. Kathoda. 2005. 
PP. Muhammadiyah, Pedoman Hidup Warga Muhammadiyah, Edisi Revisi, (Yogyakarta: Suara Muhammadiyah, 2009) 


\section{BAB X \\ MUAMALAH DAN PANDANGAN ISLAM \\ TENTANG KEHIDUPAN DUNIA}

\begin{tabular}{|c|c|c|}
\hline Nama Mata Kuliah & : & $\begin{array}{l}\text { IBADAH, AKHLAK \& } \\
\text { MUAMALAH }\end{array}$ \\
\hline $\begin{array}{l}\text { Capaian } \\
\text { Pembelajaran }\end{array}$ & : & $\begin{array}{l}\text { Mampu Menguasai konsep korelasi } \\
\text { ibadah dan akhlak dalam hubungan } \\
\text { sosial manusia (muamalah) } \\
\text { sehingga membangun motivasi } \\
\text { ibadah yang bisa menunjukkan } \\
\text { pada perubahan perilaku positif. }\end{array}$ \\
\hline $\begin{array}{l}\text { Kemampuan Akhir } \\
\text { yang diharapkan }\end{array}$ & $:$ & $\begin{array}{l}\text { Memahami tentang muamalah dan } \\
\text { pandangan islam tentang kehidupan } \\
\text { dunia. }\end{array}$ \\
\hline Alokasi Waktu & : & 100 menit \\
\hline Pertemuan ke- & $:$ & 12 \\
\hline Indikator & : & $\begin{array}{l}\text { 12.1 Menjelaskan Hakikat muamalah } \\
\text { 12.2 } \text { Menjelaskan Pandangan Islam } \\
\text { tentang kehidupan dunia } \\
\text { 12.3 Menemukan makna spiritual } \\
\text { tentang kejayaan hidup }\end{array}$ \\
\hline
\end{tabular}




\begin{tabular}{|l|l|l|}
\hline & & $\begin{array}{c}12.4 \text { Menyebutkan ruang lingkup } \\
\text { Muamalah } \\
12.5 \text { Merinci prinsip-prinsip } \\
\text { Bermuamalah } \\
12.6 \text { Menerapkan akhlak } \\
\text { bermuamalah }\end{array}$ \\
\hline Materi Pokok & $:$ & $\begin{array}{l}\text { Muamalah dan Pandangan Islam } \\
\text { Tentang Kehidupan Dunia }\end{array}$ \\
\hline
\end{tabular}

\section{A. Pendahuluan}

Pada bab ini akan dijelaskan tentang konsep muamalah dan pandangan Islam pada kehidupan duniawi. Setelah membaca uraiannya, diharapkan mahasiswa memahami model interaksi sosial yang terkonsep dalam muamalah sebagai ilmu Islam yang mengatur tentang interaksi sosial kemasyarakatan.

\section{B. Penyajian Materi}

\section{Hakikat muamalah}

Muamalah secara etimologi berasal dari bahasa Arab yang merupakan bentuk mashdar 
يُعَامِلُ -, yang bermakna saling bertindak, saling

berbuat. (Munawwir: 1997, ) Kata 'saling' disini menunjukkan adanya aktivitas yang dilakukan antara seorang dengan orang lain atau komunitas lain, sehingga kata tersebut erat kaitannya dengan interaksi sosial.

Secara terminologi, muamalah terbagi dalam dua pengertian, yakni pengertian secara luas dan pengertian secara sempit.

Dalam definisi yang luas, muamalah menurut ad-Dimyati adalah suatu aktivitas keduniaan untuk mewujudkan keberhasilan akhirat. Dr. Abdul Sattar Fathullah Sa'id dalam bukunya menyatakan bahwa fiqh muamalah adalah hukum syariah yang berkaitan dengan transaksi manusia berkaitan dengan jual beli, gadai, perdagangan, pertanian, sewamenyewa, perseroan, pernikahan, penyusuan, thalaq, iddah, hibah, hadiah, wasiat, warisan, perang dan damai (Sa'id: t.t.,12). Maka dari beberapa definisi tersebut dapat disimpulkan muamalah dalam pengertian luas adalah peraturan Allah yang 
diturunkan untuk mengatur kehidupan sosial manusia berkaitan dengan urusan duniawi.

Sedangkan dalam pengertian sempit, Khudhari Beyk berpendapat semua akad yang membolehkan manusia saling menukar manfaatnya. Menurut Dr. Mustafa Ahmad Zarqa muamalah dalam pengertian sempit adalah hukum-hukum tentang perbuatan manusia yang berkaitan dengan hubungan sesama manusia mengenai harta kekayaan, hak-hak dan penyelesaian sengketa. (Zarqa: 1966-1967, 55). Sehingga dapat disimpulkan muamalah dalam definisi yang sempit adalah Peraturan Allah untuk hubungan manusia yang berkaitan dengan kegiatan perekonomian.

Perbedaan pengertian muamalah dalam pengertian luas dan sempit adalah dalam masalah cakupan pembahasannya. Secara luas muamalah mencakup munakahat, warisan, politik dan pidana, sedangkan dalam makna sempit cakupan muamalah hanya tentang ekonomi (al-iqtishadiyah). 


\section{Pandangan Islam tentang kehidupan dunia}

Al-Qur'an sebagai kitab petunjuk khususnya bagi umat Islam telah jelas memuat peringatan Allah tentang eksistensi kehidupan dunia yang tidak kekal dan cenderung membuat terlena, melalui firman-Nya dalam Surah al-Hadid 20-21 :

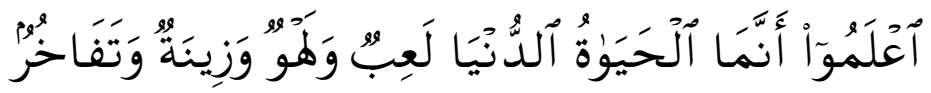

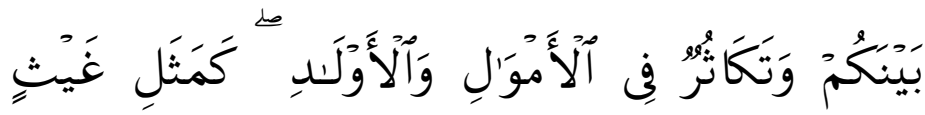

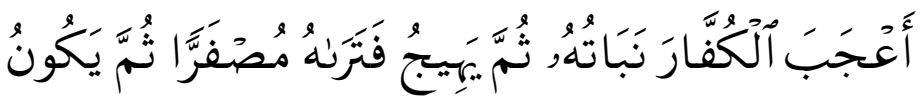

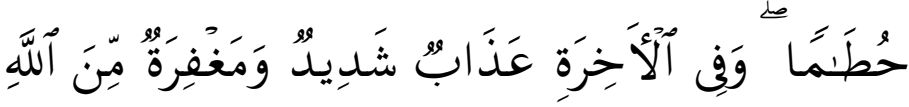

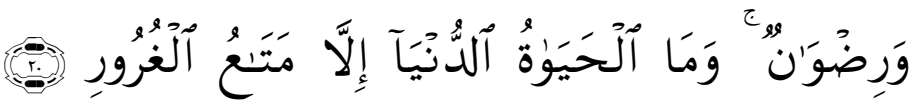

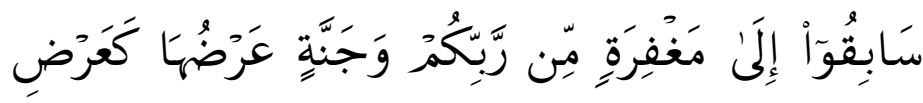

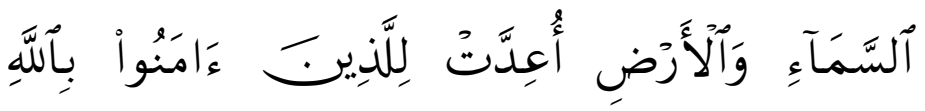

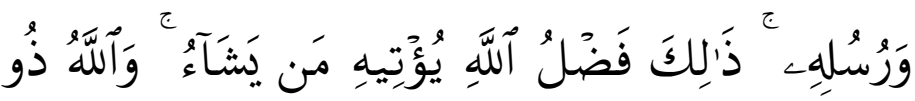

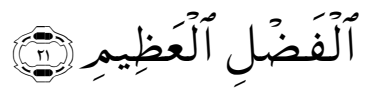

"Ketahuilah, bahwa Sesungguhnya kehidupan dunia ini hanyalah permainan dan suatu yang melalaikan, 
perhiasan dan bermegah- megah antara kamu serta berbangga-banggaan tentang banyaknya harta dan anak, seperti hujan yang tanam-tanamannya mengagumkan Para petani; kemudian tanaman itu menjadi kering dan kamu Lihat warnanya kuning kemudian menjadi hancur. dan di akhirat (nanti) ada azab yang keras dan ampunan dari Allah serta keridhaan-Nya. dan kehidupan dunia ini tidak lain hanyalah kesenangan yang menipu".

"Berlomba-lombalah kamu kepada ampunan dari Tuhanmu dan syurga yang luasnya seluas langit dan bumi, yang disediakan bagi orang-orang yang beriman kepada Allah dan rasul-rasul-Nya. Itulah karunia Allah, diberikan-Nya kepada siapa yang dikehendakiNya. dan Allah mempunyai karunia yang besar”.

Dalam ayat yang lain, QS. al-Ankabut (29):

64, Allah menegaskan:

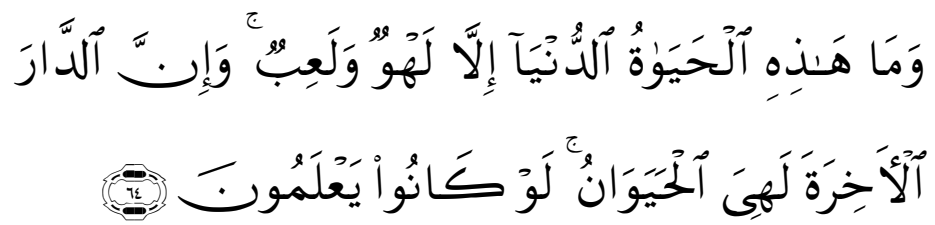

"Dan Tiadalah kehidupan dunia ini melainkan senda gurau dan main-main. dan Sesungguhnya akhirat Itulah yang sebenarnya kehidupan, kalau mereka mengetahui".

Dari ayat-ayat di atas, Allah telah memberikan petunjuk bahwa kehidupan dunia bukanlah suatu tujuan, dunia adalah tempat 
persinggahan yang penuh dengan kesenangan yang melalaikan. Negeri akhirat lah tujuan akhir kehidupan manusia, sehingga dalam ayat lain (QS. alMunafiqun:9) Allah memperingatkan:

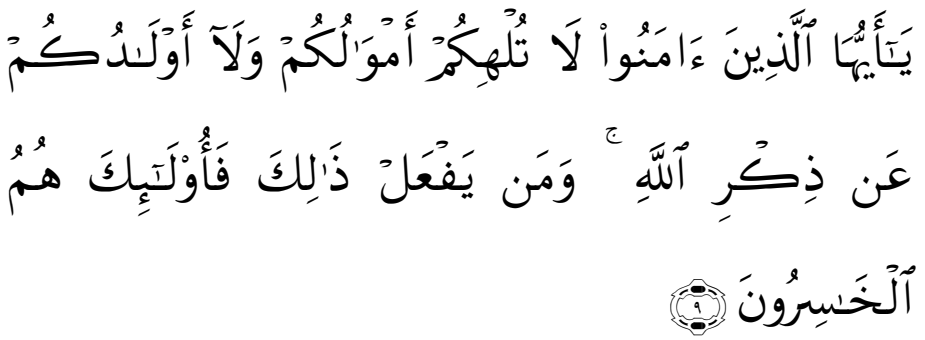

"Hai orang-orang beriman, janganlah hartamu dan anak-anakmu melalaikan kamu dari mengingat Allah. Barangsiapa yang berbuat demikian Maka mereka Itulah orang-orang yang merugi”.

Dari ayat-ayat tersebut di atas, dapat disimpulkan bahwa kehidupan dunia hakikatnya adalah kehidupan sementara yang penuh dengan permainan dan senda gurau (sesuatu yang semu), di dalamnya penuh dengan hal-hal yang nampak indah dalam pandangan manusia seperti harta dan banyaknya anak serta jabatan, keseluruhannya adalah beberapa hal yang dibanggakan manusia di dunia. Semua itu merupakan kesenangan dan kebanggaan yang tidak haqiqi, seperti tanaman yang ditanam dan 
tumbuh subur kemudian menguning, layu dan hancur. Dari tiada kembali tiada.

Melalui firman-Nya dalam al-Qur'an, Allah mengingatkan manusia untuk senantiasa waspada dengan kehidupan dan keindahan dunia yang menipu, sehingga Allah menganjurkan kepada orang-orang yang beriman agar berlomba meraih ampunan Allah dan termotivasi untuk mendapatkan syurga akhirat yang luasnya seluas langit dan bumi.

\section{Makna spiritual muamalah tentang kejayaan hidup}

Dalam keyakinan seorang muslim, merupakan suatu kewajiban baik secara individu maupun kolektif untuk kembali pada ajaran al-Qur'an dan as-Sunnah, meyakini ajarannya dan mengamalkannya dalam kehidupan sehari-hari, karena hanya dengan cara itu sajalah seorang Muslim akan terjaga dari kesesatan dan kerugian selama-lamanya serta mendapatkan keridhaan Allah. Dalam al-Qur'an Surah at-Taubah ayat 100, Allah berfirman: 


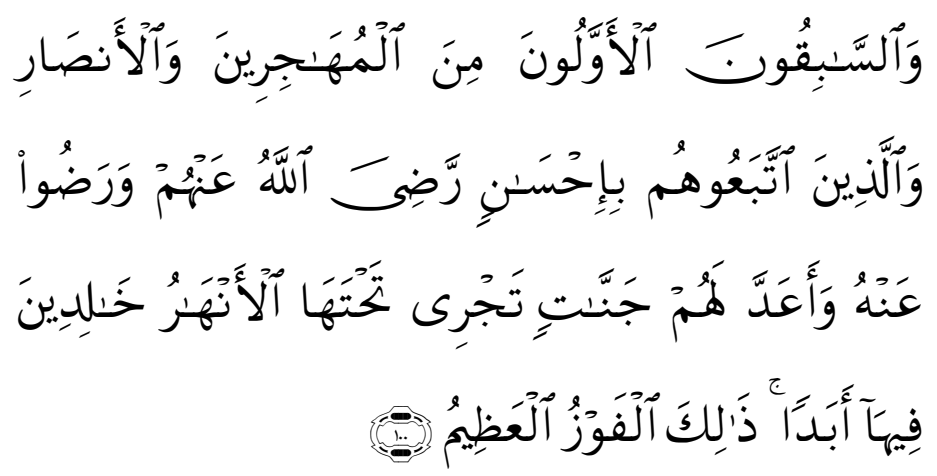

"Orang-orang yang terdahulu lagi yang pertama-tama (masuk Islam) dari golongan muhajirin dan anshar dan orang-orang yang mengikuti mereka dengan baik, Allah ridha kepada mereka dan merekapun ridha kepada Allah dan Allah menyediakan bagi mereka surga-surga yang mengalir sungai-sungai di dalamnya selama-lamanya. mereka kekal di dalamnya. Itulah kemenangan yang besar".

Ayat di atas mengisyaratkan kepada umat Islam agar senantiasa meneladani umat terdahulu (generasi pertama Nabi Muhammad SAW) dalam menjalankan kehidupan. Hal ini selaras dengan sabda Rasulullah SAW: "Sebaik-baik generasi adalah generasi sesudahku, kemudian generasi sesudahnya, kemudian generasi sesudahnya." (HR. Imam Ahmad, al-Bukhary \& Imam Muslim)

Maka jika tidak meneladani model kehidupan generasi mereka, konsekuensinya adalah 
kehidupan yang tidak menenangkan dan menentramkan, dan hal ini merupakan suatu kerugian bagi seorang Muslim. Allah berfirman dalam QS. Thaha [20] ayat 124:

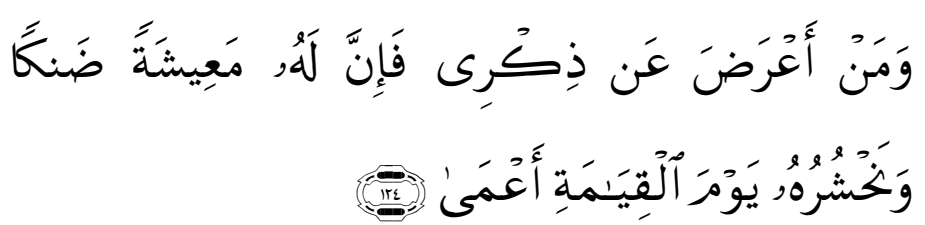

"Dan Barangsiapa berpaling dari peringatan-Ku, Maka Sesungguhnya baginya penghidupan yang sempit, dan Kami akan menghimpunkannya pada hari kiamat dalam Keadaan buta".

Pada intinya, kejayaan dan keberuntungan hanyalah milik orang-orang yang menjadikan Allah sebagai penolong, pelindung dalam kehidupan, artinya keyakinan untuk memilih Allah sebagai tempat bergantung dalam segala lini kehidupan merupakan suatu konsekuensi dari kepercayaan seorang Muslim bahwa Tidak ada Tuhan Selain Allah ( لاَ إلذَ إلاًّ الله ) (al-Qahthani, 2016: 48). Maka sikap hidup yang berdasar pada kalimat tauhid ini, tidak akan mampu direalisasikan tanpa didasari rasa cinta kepada Allah SWT. karena cinta merupakan amalan hati, maka 
seorang hamba perlu mengenal Allah SWT untuk menghadirkan rasa cintanya kepada Allah.

Beriman kepada Allah, melaksanakan apa yang diperintahkan-Nya dan menjauhi apa yang dilarang-Nya. Ikhlas melaksanakan hanya karena Allah SWT bukan sebab yang lainnya. Itulah kejayaan hidup yang haqiqi. Allah berfirman dalam QS. alMaidah [5] ayat 56 :

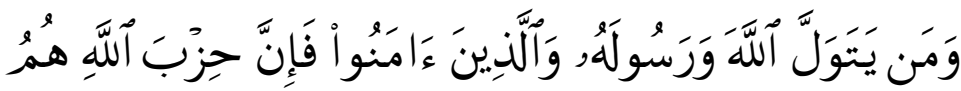

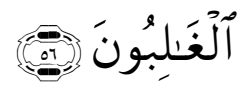

"Dan Barangsiapa mengambil Allah, Rasul-Nya dan orang-orang yang beriman menjadi penolongnya, Maka Sesungguhnya pengikut (agama) Allah Itulah yang pasti menang".

\section{Ruang lingkup muamalah}

Muamalah sebagaimana definisi luasnya yang bermakna interaksi sosial (hablun minannas) memiliki cakupan model yang berbagai macam bentuknya. Syariat Islam dalam hal ini lebih mengenalkan aturannya melalui dasar-dasar yang diperbolehkan dan yang dilarang. 
Dalam klasifikasi ajaran Islam Muamalah bersanding dengan Ibadah sebagai bagian dari Syariah Islam. Berbeda dengan Ibadah yang amalannya lebih bersifat khusus (special right) yakni pelaksanaannya karena adanya perintah, dalam hal Muamalah sifatnya lebih terbuka (public right).

Karena sifatnya yang lebih terbuka, dalam bidang muamalah berlaku asas umum, yakni pada dasarnya semua akad dan muamalah boleh dilakukan, kecuali ada dalil yang membatalkan dan melarangnya (ash-Shiddieqy, 1980, II: 91). Dari prinsip dasar ini dapat difahami bahwa semua perbuatan yang termasuk dalam kategori muamalah boleh saja dilakukan selama tidak ada ketentuan atau nash yang melarangnya. Maka dari itu, kaidah-kaidah Islam dalam bidang Muamalah lebih fleksibel; berubah seiring perkembangan zaman (Bendadeh, 2014)

Ruang lingkup syariah dalam bidang muamalah menurut Abdul Wahhab Khallaf (1978: 3233), meliputi:

a. Al-Ahkam al-ahwal al-Syakhiyyah (Hukum keluarga), yaitu hukum-hukum yang mengatur tentang hak dan kewajiban suami, istri dan anak. 
Hukum ini dimaksudkan untuk memelihara dan membangun keluarga sebagai unit terkecil dalam kelompok masyarakat.

b. Al-Ahkam al-Maliyah (Hukum Perdata), yakni hukum tentang perbuatan usaha perorangan seperti jual beli, pegadaian, perserikatan, utang piutang dan perjanjian. Hukum ini dimaksud untuk mengatur orang kaitannya dengan kekayaan dan pemeliharaan hak-hak.

c. Al-Ahkam al-Jinaiyyah (Hukum Pidana/tindak kejahatan), merupakan hukum yang bertalian dengan tindak kejahatan dan sanksi-sanksinya. Hukum ini untuk memelihara ketentraman hidup manusia dan harta kekayaannya, kehormatannya dan hak-haknya serta membatasi hubungan antara pelaku tindak kejahatan dengan korban dan masyarakat.

d. Al-Ahkam al-Murafa'at (Hukum Acara) yakni hukum yang berkaitan dengan peradilan, persaksian dan sumpah. Hukum ini dimaksud untuk mengatur proses peradilan untuk merealisasikan keadilan bagi manusia. 
e. Al-Ahkam al-Dusturiyyah (Hukum Perundangundangan) yakni hukum yang berhubungan dengan perundang-undangan untuk membatasi hubungan hakim dengan terhukum serta menetapkan hak-hak perorangan dan kelompok.

f. Al-Ahkam al-Duwaliyyah (Hukum Kenegaraan) yakni hukum yang mengatur tentang hubungan kelompok masyarakat di dalam Negara dan antar Negara. Hukum ini dimaksudkan untuk membatasi hubungan antar Negara selama masa damai dan masa perang, serta membatasi hubungan antar umat Islam dengan yang lain dalam satu Negara.

g. Al-Ahkam al-Iqtishadiyyah wa al-Maliyyah (Hukum Ekonomi dan Keuangan), merupakan hukum yang berhubungan dengan hak fakir miskin di dalam harta orang kaya, juga mengatur sumbersumber pendapatan dan masalah pembelanjaan Negara. Keberadaan hukum ini dimaksudkan untuk mengatur hubungan ekonomi antar orang kaya dengan fakir miskin dan antara hak-hak keuangan Negara dengan perseorangan.

Perbedaan pandangan tentang ruang lingkup muamalah diantara ahli hukum bisa saja berbeda, tapi 
yang pasti di dalam hukum Islam tidak dapat dipisahkan secara tegas antara hukum publik dan hukum privat. Hampir semua ketentuan hukum Islam bisa terkait dengan masalah umum dan juga terkait dengan masalah individu. Wallahu a'lam.

\section{Prinsip-prinsip bermuamalah}

Beberapa prinsip yang mendasari muamalah dalam Islam menurut Dr. Muhammad Utsman Tsabir (2007: 18-22), antara lain:

a. Muamalah dibangun di atas dasar-dasar yang umum dari Nash al-Qur'an yang berkaitan tentang Muamalah (QS. 4:29, QS. 2:188, 275).;

b. Hukum segala jenis muamalah pada mulanya adalah boleh, kecuali jika didapati ada dalil yang shahih tentang pelarangan atau yang membatasinya. (QS 10:59)

c. Fiqh muamalah dibangun di atas prinsip menjaga kemaslahatan dan 'illah (alasan disyariatkannya suatu hukum). Jika maslahatnya berubah atau hilang, maka hukum muamalah itu pun berubah.

d. Fiqh muamalah mengompromikan karakter tsubut dan murunah. Tsubut bermakna tetap, konsisten, 
tidak berubah. Artinya prinsip-prinsip Islam baik dalam persoalan aqidah, ibadah dan muamalah bersifat konsisten, tidak berubah sampai kapanpun. Akan tetapi dalam tatanan praktis, Islam -khususnya muamalah- bersifat murunah. Murunah berarti lentur, menerima perubahan dan adaptasi sesuai dengan perkembangan zaman dan kemajuan teknologi, selama tidak bertentangan dengan prinsip yang tsubut.

\section{Akhlaq bermuamalah}

Ada banyak etika yang harus dimiliki seseorang dalam bermuamalah. Diantaranya yang disebut oleh Didin Hafiduddin (2003: 33) dalam bukunya Islam Aplikatif, antara lain:

a. Shiddiq, bermakna jujur dan selalu melandasi ucapan, keyakinan dan amal perbuatan dengan dasar-dasar nilai yang benar dalam ajaran Islam (QS.9:119).

b. Istiqamah, bermakna konsisten dalam iman dan nilai-nilai yang baik, meski menghadapi berbagai macam godaan dan tantangan (QS. 41:30-31). 
c. Fathanah bermakna mengerti, memahami, menghayati secara mendalam segala yang menjadi tugas dan kewajibannya. Sebagaimana kisah Nabi Yusuf AS yang berhasil mengeluarkan bangsa Mesir dari krisis di masanya karena profesionalitas yang dimilikinya. (QS.12:55)

d. Amanah, bermakna Bertanggungjawab dalam melaksanakan setiap tugas dan kewajiban (QS.4:58)

e. Tabligh, bermakna mengajak sekaligus memberi contoh kepada pihak lain untuk melaksanakan ketentuan ajaran Islam dalam kehidupan seharihari.

\section{Rangkuman}

Kesimpulan dari materi di atas:

1. Muamalah terbagi dalam dua pengertian, yakni pengertian secara luas dan pengertian secara sempit. Muamalah secara luas dimaknai peraturan Allah yang diturunkan untuk mengatur kehidupan sosial manusia berkaitan dengan urusan duniawi; sedangkan Muamalah secara sempit bermakna Peraturan Allah 
untuk hubungan manusia yang berkaitan dengan kegiatan perekonomian.

2. Hakikat kehidupan dunia menurut al-Qur'an adalah kehidupan sementara yang penuh dengan permainan dan senda gurau (sesuatu yang semu), di dalamnya penuh dengan hal-hal yang nampak indah dalam pandangan manusia seperti harta dan banyaknya anak serta jabatan, keseluruhannya adalah beberapa hal yang dibanggakan manusia di dunia. Semua itu merupakan kesenangan dan kebanggaan yang tidak haqiqi, dari sebuah ketiadaan kembali pada ketiadaan.

3. Kejayaan dan keberuntungan hanyalah milik orangorang yang menjadikan Allah sebagai penolong, pelindung dalam kehidupan yakni diantaranya orangorang yang mau meneladani sikap hidup generasi dahulu yang mengenal Nabi Muhammad SAW walaupun tidak sezaman dengan beliau, yakni generasi sahabat, para Tabi'in dan Tabi' Tabi'in.

4. Ruang lingkup syariah dalam bidang muamalah, meliputi: a). Al-Ahkam al-ahwal al-Syakhiyyah (Hukum keluarga), b). Al-Ahkam al-Maliyah (Hukum Perdata), c). Al-Ahkam al-Jinaiyyah (Hukum Pidana/tindak kejahatan), d). Al-Ahkam al-Murafa'at 
(Hukum Acara), e). Al-Ahkam al-Dusturiyyah (Hukum Perundang-undangan), f). Al-Ahkam alDuwaliyyah (Hukum Kenegaraan) g). Al-Ahkam alIqtishadiyyah wa al-Maliyyah (Hukum Ekonomi dan Keuangan).

5. Prinsip bermuamalah

6. Pada dasarnya banyak sekali akhlaq bermuamalah yang harus dimiliki seorang muslim. Beberapa diantaranya adalah Shiddiq, Istiqamah, Fathanah, Amanah dan Tabligh.

\section{Latihan/Tugas/Eksperimen}

Jawablah pertanyaan di bawah ini:

1. Jelaskan hakikat dari muamalah!

2. Bagaimanakah makna kejayaan hidup menurut alQur'an?

3. Sebutkan min. 4 sifat yang seharusnya dimiliki seseorang dalam bermuamalah selain 5 sifat yang telah disebutkan di atas! Sertakan berikan pandanganmu atas sifat yang telah kalian sebutkan! 


\section{DAFTAR PUSTAKA}

Munawwir, Ahmad Darson. Kamus Arab-Indonesia, (Yogyakarta: Al-Munawwir, 1984)

Sa'id, Abdul Sattar Fathullah. al-Mu'amalah fi-l-Islam (Makkah: Rabithah 'Alam al-Islamy, t.t.)

Zarqa, Mustafa Ahmad. Al-Madkhal al-Fiqh Al-Am, (Damaskus: Al-Adib, 1966-1967)

al-Qahthani, Muhammad bin Sa'id. al-Wala' Wa al-Bara'; Konsep Loyalitas dan Permusuhan dalam Islam, Terj. Muzaidi, Cet. Ke-5, (Jakarta: Ummul Qura, 2016)

ash-Shiddieqy, TM. Hasbi. Pengantar Hukum Islam, Jilid II, (Jakarta: Bulan Bintang, 1980)

Bendadeh, Shafwan. Ruang Lingkup Muamalah, Tabloid Gema Baiturrahman, Jum'at - 6 Juni 2014 / 8 Syakban 1435 H | Nomor : 1067 Tahun XXI

Khallaf, Abdul Wahab. 'Ilm Ush-l al-Fiqh, (Beirut: Dar alQalam, 1978)

Hafiduddin, Didin. Islam Aplikatif, (Jakarta: Gema Insani Press, 2003)

Tsabir, Muhammad Utsman. al-Mu'amalat al-Maliyah alMu'ashirah fi al-Fiqh al-Islamy, (t.t.: Dar al-Nafais, 2007) 


\section{BAB XI \\ ISLAM DAN PERSOALAN HIDUP}

\begin{tabular}{|c|c|c|}
\hline Nama Mata Kuliah & : & $\begin{array}{l}\text { IBADAH, AKHLAK \& } \\
\text { MUAMALAH }\end{array}$ \\
\hline $\begin{array}{l}\text { Capaian } \\
\text { Pembelajaran }\end{array}$ & : & $\begin{array}{l}\text { Mampu Menguasai konsep korelasi } \\
\text { ibadah dan akhlak dalam hubungan } \\
\text { sosial manusia (muamalah) } \\
\text { sehingga membangun motivasi } \\
\text { ibadah yang bisa menunjukkan } \\
\text { pada perubahan perilaku positif. }\end{array}$ \\
\hline $\begin{array}{l}\text { Kemampuan Akhir } \\
\text { yang diharapkan }\end{array}$ & : & $\begin{array}{l}\text { Memahami Islam dan persoalan } \\
\text { hidup serta dunia kerja. }\end{array}$ \\
\hline Alokasi Waktu & : & 100 menit \\
\hline Pertemuan ke- & $:$ & 13 \\
\hline Indikator & : & $\begin{array}{l}\text { 13.1 Menjelaskan Hakekat hidup dan } \\
\text { Kerja } \\
\text { 13.2 Menjelaskan perihal rahmat } \\
\text { Allah terhadap orang yang rajin } \\
\text { bekerja } \\
\text { 13.3 Menerapkan Akhlak dalam } \\
\text { bekerja } \\
\text { 13.4 Membangun profesionalisme }\end{array}$ \\
\hline
\end{tabular}




\begin{tabular}{|l|l|l|}
\hline & & dalam bekerja \\
\hline Materi Pokok & $:$ & Islam dan Persoalan Hidup \\
\hline
\end{tabular}

\section{A. Pendahuluan}

Hidup dan persoalannya merupakan dua hal yang tidak pernah terpisahkan. Karena tidak ada kehidupan tanpa persoalan. Sifat kehidupan yang terus bergerak memunculkan permasalahan yang datang silih berganti sebagai dinamika kehidupan. Manusia dari sejak dilahirkan hingga kematiannya tidak akan pernah bisa beristirahat dari persoalan yang muncul di kehidupannya. Hal itu sudah ditetapkan Allah dalam surah al-Baqarah ayat 155 :
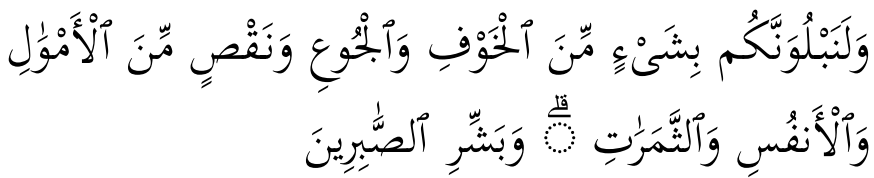

Dan sungguh akan Kami berikan cobaan kepadamu, dengan sedikit ketakutan, kelaparan, kekurangan harta, jiwa dan buahbuahan. Dan berikanlah berita gembira kepada orang-orang yang sabar.

Berkaitan dengan hal tersebut di atas, bab ini akan menguraikan tentang Islam dan Persoalan Hidup. Diharapkan setelah membacanya, mahasiswa mampu 
membangun etos kerja yang islami sebagai salah satu langkah menghadapi persoalan kehidupan dunia.

\section{B. Penyajian Materi}

\section{Hakikat hidup dan kerja}

Bekerja merupakan suatu cara bagi manusia untuk memenuhi kebutuhan hidup baik fisik, psikologis maupun sosial. Dalam sistem perekonomian Islam (Nurohman, 2011:33), bekerja dapat dimaknai sebagai berikut:

a. Bekerja sebagai peneguhan eksistensi kekhalifahan manusia di bumi. (QS.67:15)

b. Bekerja merupakan usaha yang berstatus kewajiban untuk memenuhi kebutuhan hidup.

c. Bekerja adalah ibadah; bukan hanya mengandung manfaat sosial akan tetapi juga bernilai ritual, karena bekerja bagi manusia menjadi salah satu unsur kemaslahatan sosial yang ditentukan oleh Allah SWT. (QS.62:10)

d. Bekerja merupakan perjuangan (jihad) manusia untuk mempertahankan kehidupannya. (QS.73:20)

Meski di dalam Islam Allah telah memberi ketentuan rizki yang diterima oleh ciptaan-Nya di 
muka bumi ini, akan tetapi Allah mendidik manusia untuk melakukan usaha dalam rangka memenuhi kebutuhan hidupnya. Allah SWT berfirman Surah alQashshash [28] ayat 77:

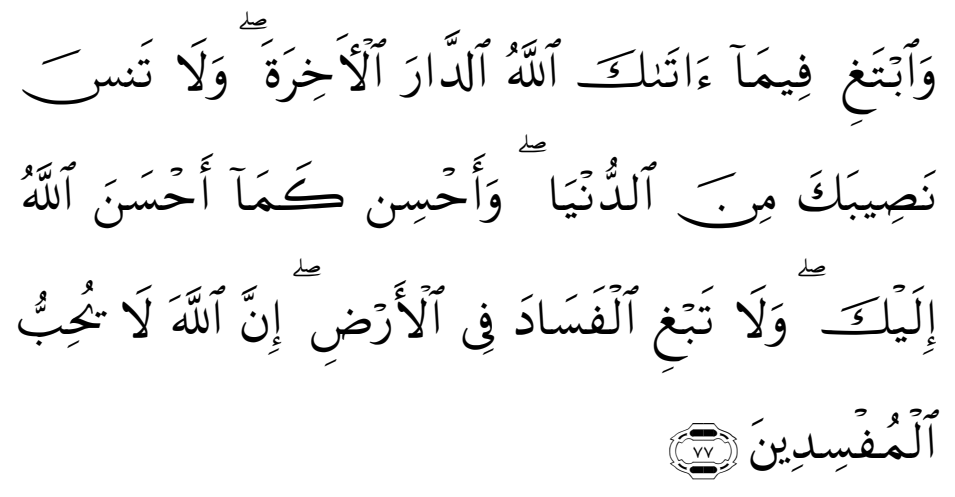

Dan carilah pada apa yang telah dianugerahkan Allah kepadamu (kebahagiaan) negeri akhirat, dan janganlah kamu melupakan bahagianmu dari (kenikmatan) duniawi dan berbuat baiklah (kepada orang lain) sebagaimana Allah telah berbuat baik, kepadamu, dan janganlah kamu berbuat kerusakan di (muka) bumi. Sesungguhnya Allah tidak menyukai orang-orang yang berbuat kerusakan.

Berdasarkan motifnya, Manusia memiliki pandangan yang berbeda-beda dalam memaknai pekerjaan mereka. Setidaknya ada empat motif dalam hal ini (Ismail: 2010), antara lain: 
1) Bekerja untuk hidup (to live). Ini merupakan fenomena kebanyakan orang, motif utamanya fisik-material, bahwa pekerjaannya sekedar untuk memenuhi kebutuhan hidupnya.

2) Bekerja untuk memperbanyak relasi (to love). Orang yang mempunyai pandangan ini, selain memaknai pekerjaan sebagai tempat mencari harta, ia juga menggunakan kesempatan bekerja untuk memperluas pergaulan. Motif utamanya adalah relasi-sosial atau komunikasi antar sesama (interhuman relations).

3) Bekerja untuk belajar (to learn). Motif utamanya intelektual. Orang tipe ketiga ini memaknai pekerjaannya sebagai tempat mencari ilmu, menambah pengalaman dan menguji kemampuan.

4) Bekerja untuk berbagi kenikmatan dan mewariskan kebaikan (to leave a legacy). Orang tipe keempat ini memaknai pekerjaannya sebagai ibadah kepada Allah SWT. motif utamanya lebih mengarah kepada spiritualitas. Pekerjaan apapun yang dimilikinya, selalu memotivasi dirinya untuk 
berbuat kebaikan dan memberikan manfaat kepada lingkungan sekitarnya. Tipe inilah yang terbaik di dalam agama Islam sebagaimana Rasulullah SAW bersabda: "Sebaik-baik manusia adalah orang yang paling bermanfaat untuk yang lainnya" (HR. Thabrani)

\section{Rahmat Allah terhadap orang yang rajin bekerja}

Rajin bekerja dalam Islam konteksnya lebih pada makna tidak malas bekerja, pekerja keras bukan workaholic. Dua konteks tersebut mempunyai perbedaan definisi, workaholic istilah lainnya adalah pecandu kerja, gila kerja, sehingga seluruh hidupnya hanya dihabiskan untuk pekerjaannya, sedangkan pekerja keras (hardworker) adalah orang yang berkontribusi maksimal untuk pekerjaannya tetapi tidak melalaikan kehidupan sosial lainnya (https://id.wikipedia.org/wiki/Workaholic). Seorang pekerja keras lebih memaknai pekerjaannya sebagai suatu usaha untuk bertahan hidup dan menjaga kehormatannya, dalam Islam bersikap iffah (menjaga 
kehormatan diri) telah diajarkan Rasulullah SAW salah satunya melalui hadis larangan menjadi peminta-minta. Hadis diriwayatkan Abdullah bin Umar, Rasulullah bersabda:

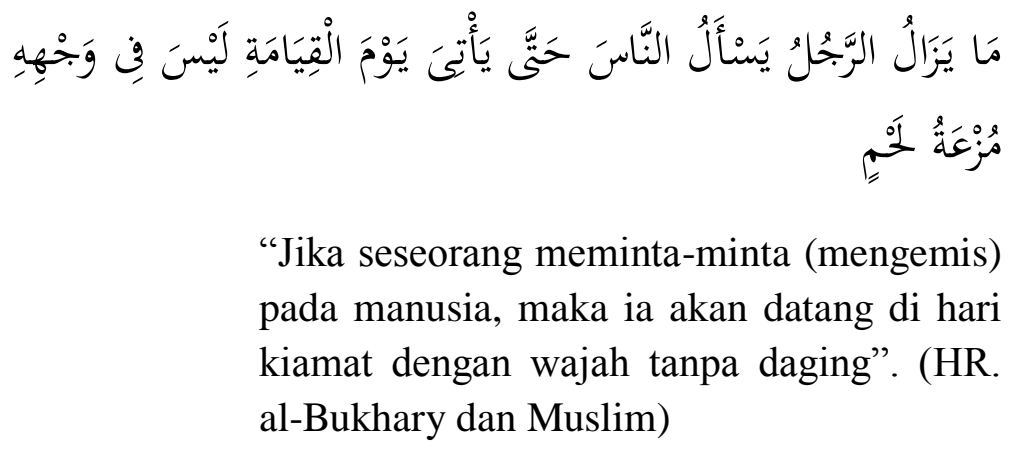

Dalam hadis lain yang diriwayatkan Hubsyi bin Junadah, Rasulullah SAW bersabda:

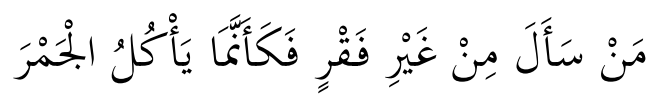

"Barangsiapa meminta-minta padahal dirinya tidak fakir, maka dia seolah-olah memakan bara api" (HR. Imam Ahmad)

Dalam Islam Rasulullah SAW mengharamkan perbuatan meminta-minta, kecuali dalam tiga keadaan. Sebagaimana sabda Rasulullah SAW kepada sahabat Qobishoh: 


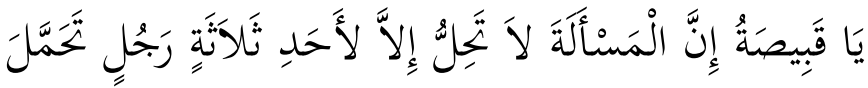

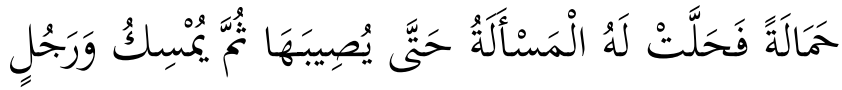

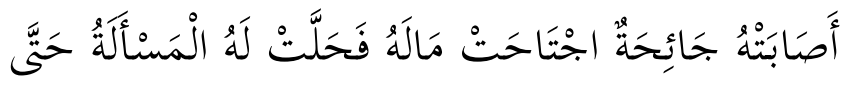

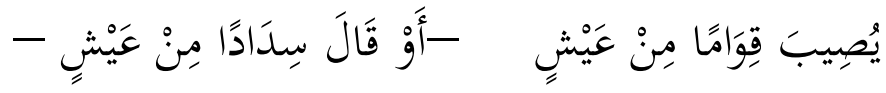

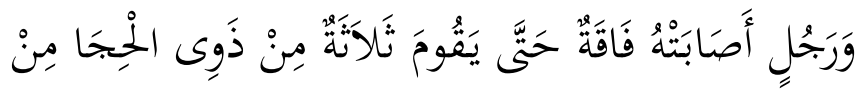

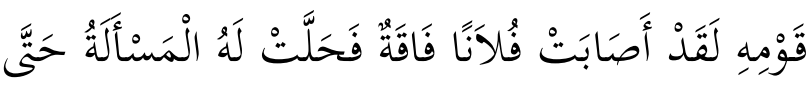

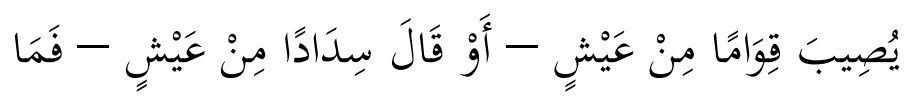

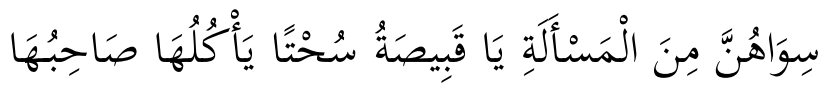

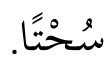

"Wahai Qobishoh, sesungguhnya memintaminta itu tidak halal kecuali untuk tiga orang: 1). Seseorang yang menanggung hutang orang lain, ia boleh mengemis sampai ia melunasinya, 2). Seseorang yang ditimpa musibah hingga habis hartanya, ia boleh mengemis sampai ia mendapatkan sandaran hidup, dan 3). Seseorang yang ditimpa kesengsaraan hidup sehingga ada tiga orang yang berakal dari kaumnya berkata, Si Fulan benar-benar telah tertimpa kesengsaraan, maka boleh baginya meminta-minta sampai mendapatkan sandaran hidup. Selain ketiga golongan itu Wahai Qobishoh, adalah haram dan orang yang memakannya berarti memakan harta yang haram" (HR. Muslim No.1044) 
Memahami hadis di atas, mengemis merupakan perbuatan yang harus dihindari kecuali dalam keadaan yang sangat mendesak, sebagaimana digambarkan oleh Rasulullah SAW pada tiga keadaan tersebut.

Dalam al-Qur'an perintah bekerja terdapat di berbagai surah, salah satunya QS. al-Jumu'ah [62] ayat 10

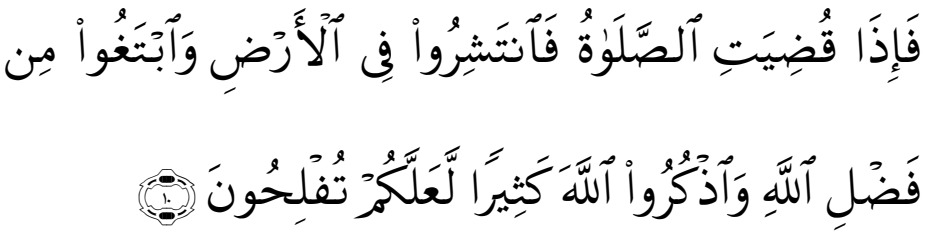

Apabila telah ditunaikan shalat, Maka bertebaranlah kamu di muka bumi; dan carilah karunia Allah dan ingatlah Allah banyak-banyak supaya kamu beruntung.

Berkaitan dengan ayat di atas, Ibnu Katsir dalam tafsirnya menyebutkan "Diriwayatkan dari Ibnu Abi Hatim dan sebagian salaf bahwa barangsiapa yang membeli atau menjual sesuatu pada hari jum'at setelah shalat, Allah akan memberkahi untuknya 70 kali." (ad-Dimasyqi, 2004: 276) Nabi SAW juga pernah 
bersabda: "Tidaklah seseorang memakan makanan yang lebih baik dari makanan yang dihasilkan dari pekerjaan tangannya sendiri" (HR. Imam al-Bukhary). Dalil-dalil di atas menjadi suatu bukti bahwa Islam mengajarkan tentang etos kerja yang baik bagi pemeluknya. Hasil yang dicapai tidak selalu berorientasi pada harta yang banyak, tetapi konteksnya lebih pada rahmah dan barokah.

Rahmah dimaknai sebagai kasih sayang Allah kepada segenap makhluk-Nya. Kasih sayang di dunia berupa anugerah, hidayah, rizki dan perlindungan Allah, sedangkan di akhirat rahmat Allah salah satunya berupa Syurga. (Shihab, 2006:22). Barokah dalam Kitab Sharah Shahih Muslim karya Imam an-Nawawi dijelaskan memiliki dua arti kata, 1). Tumbuh, berkembang dan bertambah, 2) Kebaikan yang berkesinambungan. Imam al-Ghazali memberi makna bertambahnya kebaikan (Mujieb, dkk., 2009:79). Sehingga dari sini dapat disimpulkan bahwa orang yang rajin bekerja dan ikhlas melakukannya maka ia dianugerahi Allah kebaikan-kebaikan dalam kehidupannya. Kebaikan itu bisa berupa ketentraman dalam hidup, keluarga yang shalih, kesehatan yang 
prima, waktu yang bermanfaat, dan kebaikankebaikan yang lain.

Motivasi untuk giat bekerja disampaikan juga oleh Rasulullah SAW dalam hadis:

مَغْفْوُرًا لَهُ. رواه الطبرانى

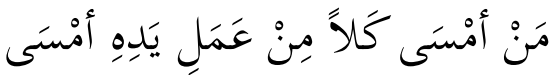

Barangsiapa yang sore hari duduk kelelahan lantaran pekerjaan yang dilakukannya, maka ia dapatkan sore hari tersebut dosadosanya diampuni oleh Allah SWT. (HR. Imam ath-Thobrony)

Pada intinya konsep rajin bekerja dalam Islam merupakan sikap pekerja keras yang ketika melaksanakan pekerjaannya tidak melupakan hak-hak Allah SWT., apabila hal ini dilaksanakan secara dinamis maka disitulah akan berlaku rahmat dan barokahNya.

\section{Akhlaq dalam bekerja}

Realisasi konsep bekerja dalam Islam perlu dibangun dengan nilai etika bekerja yang Islami, agar hasil akhir yang dicapai selalu mengandung unsur ibadah dan berdampak rahmah kepada pelaku serta orang-orang yang ada di sekitarnya. Menurut Rikza Maulan, Lc., M.Ag (2009:10) Etika bekerja dalam 
Islam diantaranya: (1) Bekerja dengan Ikhlas karena Allah SWT, (2) Itqon, tekun dan sungguh-sungguh dalam bekerja, (3) Jujur dan amanah, (4) Menjaga etika sebagai seorang muslim, (5) Tidak melanggar prinsip-prinsip syariah, (6) Menghindari syubhat, dan (7) Menjaga ukhuwah islmaiyah.

Menjaga akhlaq yang baik selain akan membentuk perilaku positif, juga akan membuka pintu-pintu kerahmatan Allah SWT, tidak akan bermakna kualitas sumber daya insani tanpa dibarengi dengan karakter yang baik dan pendidikan profesi kepada manusia yang berkarakter baik pasti akan mampu menghasilkan sumber daya manusia yang benar-benar berkualitas.

\section{Profesionalisme dalam bekerja}

Profesional dalam Kamus Besar Bahasa Indonesia berarti mutu, kualitas dan tindak tanduk yang merupakan ciri suatu profesi atau orang yang profesional (https://kbbi.web.id/profesionalisme).

Profesional menunjukkan bahwa profesinya tidak hanya sekedar suatu pekerjaan biasa melainkan sebuah pekerjaan utama, bukan sekedar menyalurkan 
hobby atau pengisi waktu luang. Tambahan kata isme bila dimaknai sebagai pandangan hidup, maka profesionalisme bisa dimaknai sebagai pandangan untuk selalu bekerja dan berfikir secara sungguhsungguh, disiplin dengan loyalitas yang tinggi dan penuh dedikasi.

Dengan demikian, profesionalitas sangat dibutuhkan terutama dalam dunia pekerjaan. Sikap profesional melahirkan suatu kerja maksimal yang tidak dilandasi oleh keterpaksaan melainkan berdasar pada panggilan jiwa yang berkaitan dengan keahlian dan profesi yang diembannya.

Aktualisasi profesionalisme dalam Islam bisa dilihat dari beberapa prinsip yang terdapat dalam nash, diantaranya:

1. Pekerjaan harus dilaksanakan berdasarkan pengetahuan yang qualified. (QS. al-Isra'[17]:36)

2. Pekerjaan harus diberikan sesuai dengan bidang keahliannya. (QS. an-Nisa'[4]:58)

3. Dikerjakan dengan cara yang sungguh-sungguh. (QS. al-Insyirah [94]: 7-8) 
4. Tidak dzalim baik terhadap diri sendiri maupun orang lain baik selaku pimpinan ataupun karyawan (QS. ash-Shura [42]:39)

\section{Rangkuman}

Ringkasan materi di atas, antara lain:

1. Kerja dalam kehidupan dapat dimaknai sebagai berikut: a. Bekerja sebagai peneguhan eksistensi kekhalifahan manusia di bumi; (QS.67:15), b. Bekerja merupakan usaha yang berstatus kewajiban untuk memenuhi kebutuhan hidup; c. Bekerja adalah ibadah bukan hanya mengandung manfaat sosial akan tetapi juga bernilai ritual (QS.62:10); d. Bekerja merupakan perjuangan (jihad) manusia untuk mempertahankan kehidupannya. (QS.73:20)

2. Rajin bekerja dalam Islam konteksnya lebih pada makna pekerja keras bukan workaholic. Pekerja keras (hardworker) adalah orang yang berkontribusi maksimal untuk pekerjaannya tetapi tidak melalaikan kehidupan sosial lainnya. Dalam Islam, rajin bekerja menjadi penting kaitannya dengan bertahan hidup dan menjaga kehormatan. Maka inti dari konsep pekerja keras yang mendapat rahmat Allah adalah 
orang yang rajin bekerja tetapi tidak melalaikan hakhak Allah SWT.

3. Etika bekerja dalam Islam diantaranya: (1) Bekerja dengan Ikhlas karena Allah SWT, (2) Itqon, tekun dan sungguh-sungguh dalam bekerja, (3) Jujur dan amanah, (4) Menjaga etika sebagai seorang muslim, (5) Tidak melanggar prinsip-prinsip syariah, (6) Menghindari syubhat, dan (7) Menjaga ukhuwah islmaiyah.

4. Aktualisasi profesionalisme dalam Islam bisa dilihat dari beberapa prinsip yang terdapat dalam nash, diantaranya: a). Pekerjaan harus dilaksanakan berdasarkan pengetahuan yang qualified; b). Pekerjaan harus diberikan sesuai dengan bidang keahliannya; c). Dikerjakan dengan cara yang sungguh-sungguh; d). Tidak dzalim baik terhadap diri sendiri maupun orang lain baik selaku pimpinan ataupun karyawan.

\section{Latihan/Tugas/Eksperimen}

Diskusikan tentang beberapa perbedaan antara Pekerja Keras dan Workaholic! 


\section{DAFTAR PUSTAKA}

Nurohman, Dede. Memahami Dasar-Dasar Ekonomi Islam, (Yogyakarta: Teras, 2011)

Ismail, A.Ilyas. Mari Kita Mewariskan Kebaikan, http://www.republika.co.id/berita/ensiklopediaislam/hikmah/10/12/01/149925-mari-kita-mewariskankebaikan, diunduh 31-08-2017 ad-Dimasyqi, Al-Imam Abu al-Fida Ismail Ibnu Katsir. Tafsir al-Qur'an al-Adhim, Juz 28, Terj. Bahrun Abu Bakar, Cet. Ke-1 (Bandung: Penerbit Sinar Baru Algensindo, 2004)

Shihab, M. Quraish. Tafsir al-Mishbah; Pesan, Kesan dan Keserasian al-Qur'an, Vol.1, Cet. Ke-VIII, (Jakarta: Lentera Hati, 2006)

Mujieb, M. Abdul. dkk., Ensiklopedia Tasawuf Imam alGhazali, Cet.ke-1(Jakarta: Hikmah, 2009) https://kbbi.web.id/profesionalisme diunduh 06-09-2017 Maulan, Rikza. Akhlak dan Etika Bekerja dalam Islam (Etika Bisnis Islam), makalah disampaikan Januari 2009 


\section{BAB XII \\ HARTA DAN JABATAN DALAM PANDANGAN \\ ISLAM}

\begin{tabular}{|c|c|c|}
\hline Nama Mata Kuliah & : & $\begin{array}{l}\text { IBADAH, AKHLAK \& } \\
\text { MUAMALAH }\end{array}$ \\
\hline $\begin{array}{l}\text { Capaian } \\
\text { Pembelajaran }\end{array}$ & $:$ & $\begin{array}{l}\text { Mampu Menguasai konsep korelasi } \\
\text { ibadah dan akhlak dalam hubungan } \\
\text { sosial manusia (muamalah) } \\
\text { sehingga membangun motivasi } \\
\text { ibadah yang bisa menunjukkan } \\
\text { pada perubahan perilaku positif. }\end{array}$ \\
\hline $\begin{array}{l}\text { Kemampuan Akhir } \\
\text { yang diharapkan }\end{array}$ & : & $\begin{array}{l}\text { Memahami tentang Masalah Harta } \\
\text { dan Jabatan dalam Pandangan } \\
\text { Islam }\end{array}$ \\
\hline Alokasi Waktu & $:$ & 100 menit \\
\hline Pertemuan ke- & $:$ & 14 \\
\hline Indikator & : & $\begin{array}{l}\text { 14.1 Menjelaskan Harta \& jabatan } \\
\text { sebagai amanah dan karunia } \\
\text { Allah } \\
\text { 14.2 } \text { Menjelaskan Kewajiban } \\
\text { mencari Harta }\end{array}$ \\
\hline
\end{tabular}




\begin{tabular}{|l|l|l|}
\hline & & $\begin{array}{r}14.3 \text { Menetapkan sikap terhadap } \\
\text { harta dan jabatan } \\
\text { 14.4 Memahami pendayagunaan } \\
\text { harta dan jabatan di jalan Allah }\end{array}$ \\
\hline Materi Pokok & $:$ & $\begin{array}{l}\text { Harta dan Jabatan dalam } \\
\text { Pandangan Islam }\end{array}$ \\
\hline
\end{tabular}

\section{A. Pendahuluan}

Islam memiliki dimensi yang sangat luas dalam memberikan perhatian bagi kehidupan manusia, termasuk dalam pemeliharaan harta dan jabatan. Syariah Islam menempatkan pemeliharaan harta dan jabatan secara eksplisit ke dalam salah satu dari lima prinsip syariah, yaitu: memelihara harta (حفظ المال), memelihara agama (حفظ الدين), memelihara diri atau individu (حفظ النفس), memelihara akal (حفظ (حفظ النسل (حفل), memelihara keturunan (Djamil, 1999: 125).

Jabatan dalam kaca mata Islam tidak mengenal adanya dikotomi atau pemisahan dari dengan aturan syariah Islam. Jabatan sebagai bagian yang tidak terpisahkan dari 
upaya merealisasikan ajaran agama dalam kehidupan manusia. Oleh karenanya, seseorang yang mendapatkan amanah suatu jabatan tertentu adalah bagian kewajiban untuk merealisasikan perintah agama dalam kehidupan, terutama memberikan kamaslahatan kepada orang lain. Berpijak dari kelima unsur pokok yang harus dipelihara di atas, maka dalam memangku jabatan harus mampu merealisasikan حفظ ( (الدين).

Sedangkan harta diterjemahkan sebagai barang atau uang yang menjadi kekayaan seseorang, sedangkan jabatan diterjemahkan sebagai kedudukan yang diamanatkan kepada seseorang. Keduanya selalu menghiasi kehidupan manusia di dunia. Meskipun demikian, kedua hal tersebut bisa berperan bagi manusia dalam menentukan keselamatan manusia, baik di dunia maupun di akhirat kelak.

Berdasarkan uraian di atas, capaian pembelajaran pada bab ini adalah mahasiswa dapat memahami: (1) harta dan jabatan sebagai amanah dan karunia Allah; (2) kewajiban mencari harta; (3) sikap terhadap harta dan jabatan; dan (4) pendayagunaan harta dan jabatan di jalan Allah. Keempat 
bahasan tersebut akan diuraian secara terperinci penyajian materi.

\section{B. Penyajian Materi}

\section{Harta dan jabatan sebagai amanah dan karunia}

\section{Allah}

Seorang muslim, wajib baginya mengimani bahwa pemilik segala sesuatu, baik yang ada di bumi maupun di langit adalah hak milik Allah SWT semata. Inilah dijelaskan dalam firmanNya:

\section{إِنَّا لِلِّهِ وَإِنَّا إِلَيْهِ رَاجِعونَ}

Artinya: "Sesungguh-nya kami milik Allah dan kepada-Nya-lah kami kembali”. (QS. al-Baqarah [2]: 156).

Ayat di atas, mengisyaratkan bahwa yang ada di alam semesta termasuk manusia itu sendiri, hanya milik Allah dan kepadanyalah manusia akan dimintai pertanggungjawaban atas apa yang telah Allah berikan kepada manusia. Oleh karena itu, harta dan jabatan dapat dipahami sebagai amanah yang diberikan Allah kepada manusia untuk merealisasikan ajaran Islam dalam kehidupan. 
Amanah memiliki beberapa pengertian, yaitu amanah sebagai sesuatu yang dititipkan kepada orang lain (Departemen Pendidikan Nasional, 2008: 47). Dawam Rahardjo, juga menjerlaskan bahwa amanah mempunyai akar yang sama dengan kata iman (percaya) dan amana yang berarti memberikan, memiliki kepercayaan, atau trust, dan juga berarti aman (dalam pengertian Indonesia) (Dawam Rahardjo, 1999: 331-332).

Berdasarkan pengertian di atas, amanah sebagai bagian dari iman seseorang, sehingga menjadi kewajiban untuk dilaksanakan secara semaksimal dan seoptimal mungkin. Optimalisasi manusia dalam mewujudkan amanah tersebut, akan mengantarkan manusia mampu memenuhi amanah dalam mencari harta dan mengemban jabatan sesuai tujuan syariah tentang harta dan jabatan. Hal ini Allah berfirman:

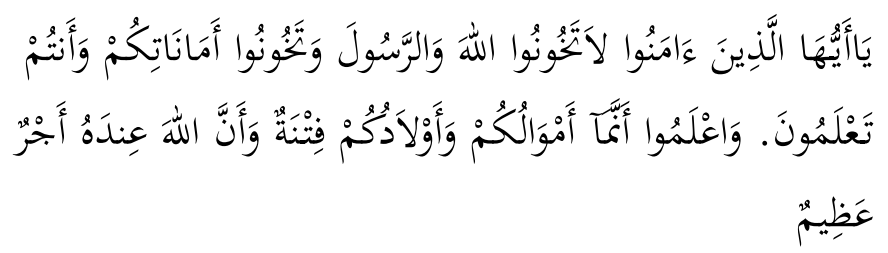

Artinya: "Hai orang-orang beriman, janganlah kamu, mengkhianati Allah dan Rasul (Muhammad) dan juga janganlah kamu mengkhianati amanat-amanat 
yang dipercayakan kepadamu, sedang kamu mengetahui". "Dan ketahuilah, bahwa hartamu dan anak-anakmu itu hanya sebagai cobaan dan sesungguhnya di sisi Allah-lah pahala yang besar" (QS. al-‘Anfaal [8]: 27- 28).

Dengan demikian, hakikat harta dan dan jabatan adalah merupakan amanah dan karunia Allah. Oleh karenanya, harta wajib dijaga dan dijalankan atau dipelihara serta dilaksanakan sesuai kehendak yang memberi amanah, yakni Allah SWT.

\section{Kewajiban mencari harta}

Kebutuhan dan keinginan manusia menjadi pendorong utama bagi kegiatan memperoleh harta, yang tidak mungkin bisa dipenuhi secara mandiri (Shihab, 2003: 530). Kegiatan yang dilakukan adalah dengan melakukan muamalah, melakukan transaksi dengan orang lain, dengan tujuan saling memberikan manfaat, bisa dengan melakukan jual-beli maupun melakukan kegiatan barter seperti dilakukan oleh masyarakat pada masa lalu sebelum ditemukannya uang sebagai alat pertukaran yang sah.

Islam tidak menyukai orang yang malas, yang tidak mau berusaha mencari rezeki. Justru Islam 
mendorong kepada umat muslim agar giat mencari harta. Sebagaimana dijelaskan dalam firman Allah berikut:

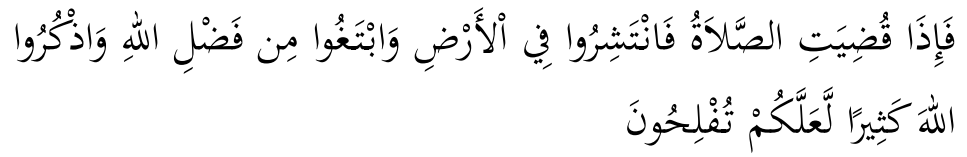

Artinya: "Apabila telah ditunaikan shalat, maka bertebaranlah kamu di muka bumi; dan carilah karunia Allah dan ingatlah Allah banyak-banyak supaya kamu beruntung" (QS. al-Jumuah [9]: 10).

Dijelaskan pula melalui kisah Nabi Daud AS, yang berusaha membuat sendiri baju besi, dan tidak berpangku tangan menunggu belas kasihan dari orang lain.

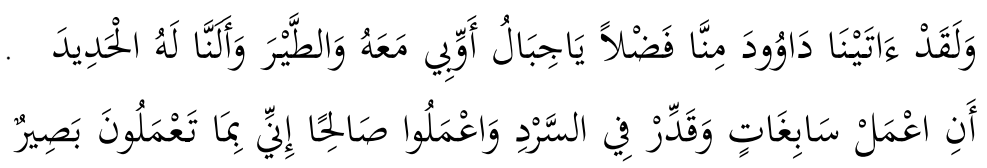

Artinya: "Dan sesungguhnya telah Kami berikan kepada Daud kurnia dari Kami. (Kami berfirman):"Hai gunung-gunung dan burung-burung, bertasbihlah berulang-ulang bersama Daud", dan Kami telah melunakkan besi untuknya. (yaitu) buatlah baju besi yang besar-besar dan ukurlah anyamannya; dan kerjakanlah amalan yang saleh. Sesungguhnya Aku melihat apa yang kamu kerjakan. (QS. Saba' [34]: 10-11) 
Rasulullah SAW sendiri menyuruh kepada umatnya agar mau bekerja dan melarang memintaminta. Sebagaimana ditegaskan dalam riwayat hadits berikut:

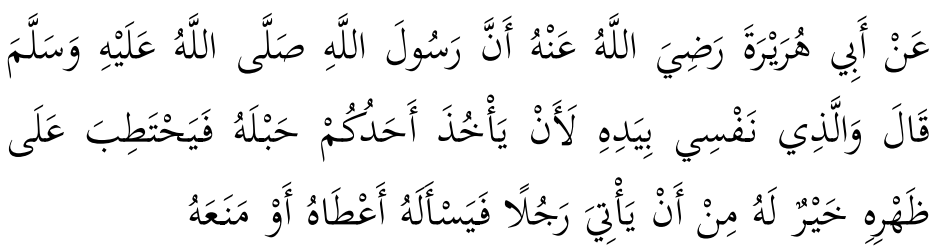

"Dari Abu Hurairah radliallahu 'anhu bahwa Rasulullah Shallallahu'alaihiwasallam bersabda: "Demi Dzat yang jiwaku berada di tanganNya, sungguh seorang dari kalian yang mengambil talinya lalu dia mencari kayu bakar dan dibawa dengan punggungnya lebih baik baginya daripada dia mendatangi seseorang lalu meminta kepadanya, baik orang itu memberi atau menolak". (HR. al-Bukhari: 1377)

Dengan demikian, dapat dipahami bahwa perintah mencari harta bukan dimaksudkan sekedar memenuhi kebutuhan hidup, atau hanya sebatas memenuhi hasrat kepentingan duniawi. Aktifitas mencari harta juga harus diorientasikan untuk menunjang keperluan akhirat. Quraish Shihab, menjelaskan bahwa istilah fadhl Allah yang diterjemahkan sebagai "kelebihan yang bersumberkan 
dari Allah", dimaksudkan agar yang memperoleh dapat melakukan ibadah secara sempurna serta mengulurkan tangan bantuan kepada pihak-pihak yang lain yang tidak berkecukupan (Shihab, 2003: 403).

Islam mendorong terciptanya etos kerja yang tinggi. Islam memberikan penghargaan terhadap konsep kepemilikan bahwa segala yang terdapat di bumi dan di langit adalah milik Allah SWT, dan semua merupakan sumber rezeki yang bersifat terbuka bagi manusia yang mau bekerja untuk mencarinya. Ditegaskan pula, melalui konsep persamaan antara sesama manusia, dan ukuran ketinggian derajat dinilai dari tingkat ketakwaan, iman, dan amal shalehnya, berperan besar dalam membangun etos kerja yang tinggi (Rahardjo, 1999: 277). Pemberdayaan lembaga seperti zakat, infak dan shadaqah dalam menyalurkan harta orang yang mampu telah memberikan motivasi dalam menjalankan tanggung jawab sosial. Upaya memenuhi tanggung jawab sosial ini juga sangat dihargai. Faktor fundamental inilah yang mendorong semangat bekerja dalam Islam, yang orientasinya tidak sekedar memenuhi kepentingan duniawi, tetapi juga 
untuk menunjang kepentingan akhirat. Jika kepentingan duniawinya adalah untuk memenuhi kebutuhan hidup, sedangkan kepentingan akhirat adalah tanggungjawabnya menolong sesama.

\section{Sikap terhadap harta dan jabatan}

Dari uraian sebelumnya, menjelaskan bahwa Allah adalah pemilik segala sesuatu, termasuk harta yang dimiliki manusia. Meskipun diperoleh melalui usaha keras, memeras keringat, namun tetap saja pada hakikatnya, harta tersebut adalah milik Allah yang dititipkan kepada orang tersebut. Demikian pula jabatan yang dimiliki seseorang juga merupakan amanah yang harus dipertanggungjawabkan. Jika demikian, yang perlu diperhatikan adalah sikapnya terhadap harta dan jabatan, agar tidak senantiasa menjadikan harta dan jabatan sebagai tujuan utama, melainkan dijadikan sebagai media untuk memenuhi tanggungjawabnya sebagai hamba Allah SWT. 
Dengan demikian, harta dan jabatan adalah urusan dunia. Kendatipun demikian, bisa menyebabkan seseorang sukses ataupun gagal dalam menggapai kehidupan akhirat. Harta pada dasarnya bisa berupa karunia yang diberikan Allah, yang berarti pula akan menguji manusia apakah dirinya mampu menggunakan harta dan jabatannya tersebut untuk kepentingan yang diridhai Allah, atau malah sebaliknya, justru terlena dan terhanyut mendewakan harta, sehingga melakukan tindakan yang tidak dibenarkan. Misalnya, melakukan manipulasi, korupsi, kolusi, perusakan, penipuan, atau perbuatan tercela lainnya. Allah sendiri dalam firman-Nya menegaskan, bahwa harta adalah cobaan, yang mengharuskan manusia berhati-hati dalam menggunakan cara untuk memperoleh harta dan mendayagunakannya. Jika yang dilakukan salah bisa jadi harta tersebut akan menyebabkan manusia tersebut menemui kesukaran, bukan hanya kesukaran di akhirat kelak ketika dimintai pertanggung jawaban, melainkan termasuk di dunia.

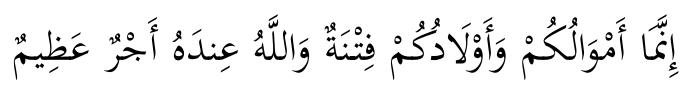


Artinya: "Sesungguhnya hartamu dan anak-anakmu hanyalah cobaan (bagimu); dan di sisi Allahlah pahala yang besar" (QS. at-Taghabun [64]: 15).

Hal ini juga ditegaskan dalam firman Allah yang lain bahawa harta adalah perhiasan dunia,

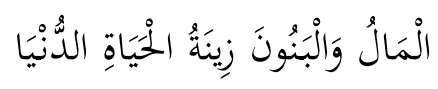

Artinya: "Harta dan anak-anak adalah perhiasan kehidupan dunia" (QS. al-Kahfi [18]: 46).

Sikap terhadap harta dan jabatan adalah dengan menjaga diri bahwa harta yang dimiliki adalah karunia yang diberikan Allah, yang bisa jadi akan mengujinya untuk menjadi hamba yang bersyukur atau seorang hamba yang kufur serta menjalankan jabatan yang diterima sebagai amanah dan menggunakan jabatan tersebut untuk kemaslahatan umat.

\section{Pendayagunaan harta dan jabatan di jalan Allah.}

Kecenderungan manusia terhadap harta dan jabatan merupakan kebutuhan yang mendasar. Hal ini dijelaskan dalam firman Allah berikut: 


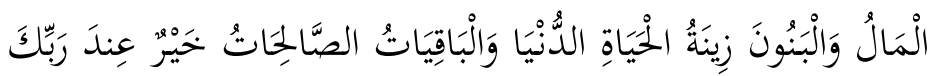

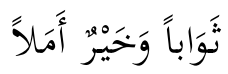

Artinya: "Harta dan anak-anak adalah perhiasan kehidupan dunia tetapi amalan-amalan yang kekal lagi shaleh adalah lebih baik pahalanya di sisi Tuhanmu serta lebih baik untuk menjadi harapan". (QS. al-Kahfi [18]: 46).

Ayat di atas, kebutuhan manusia terhadap harta disamakan dengan kebutuhan terhadap keturunan atau anak. Manusia seringkali terperdaya dalam memenuhi kebutuhan tersebut, sehingga lupa dengan tugas dan tanggungjawabnya sebagai hamba Allah SWT, dan khalifah di bumi. Manusia sebagai hamba Allah, yakni mengabdi dan menyembah-Nya. Manusia, sebagai khalifah manusia bertugas untuk menjaga kelestarian alam. Untuk memenuhi kebutuhan hidup, manusia boleh melakukan aktifitas yang seharusnya bisa dipertanggungjawabkan, terutama kepada Allah SWT yang telah menciptakan manusia dan yang memberikan amanah kepada manusia. 


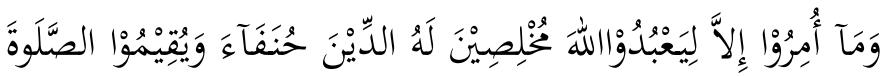

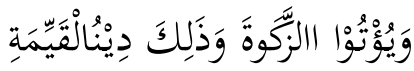

Artinya: "Padahal mereka tidak disuruh kecuali supaya menyembah Allah dengan memurnikan keta'atan kepada-Nya dalam (menjalankan) agama yang lurus, dan supaya mereka mendirikan shalat dan meunaikan zakat; dan yang demikian itulah agama yang lurus" (QS. al-Bayyinah [98]: 5).

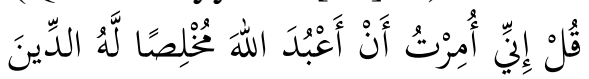

Artinya: Katakanlah: "Sesungguhnya aku diperintahkan supaya menyembah Allah dengan memurnikan ketaatan kepada-Nya dalam (menjalankan) agama. (QS. az-Zumar [43]:11)

Dengan demikian, hakikat harta memiliki daya tarik agar seseorang bisa kaya, memiliki materi yang berlimpah, kemewahan, serta dengan mudah memenuhi kebutuhannya. Jabatan juga memiliki daya tarik agar seseorang dihormati, dan mudah membangun akses dengan orang yang mempunyai kedudukan yang sangat penting untuk saling bekerjasama. Namun, jika yang dominan adalah keinginan negatifnya berarti telah terjadi penyimpangan terhadap fungsi dan tujuan penciptaan dirinya sebagai manusia. Hal ini Islam secara tegas menyatakan: 


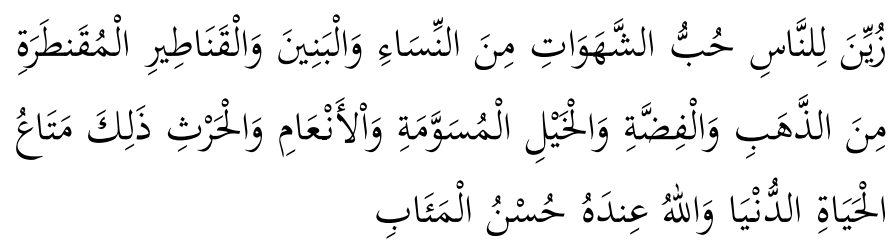

Artinya: "Dijadikan indah pada (pandangan) manusia kecintaan kepada apa-apa yang diingini, yaitu: wanita-wanita, anak-anak, harta yang banyak dari jenis emas, perak, kuda pilihan, binatangbinatang ternak dan sawah ladang. Itulah kesenangan hidup di dunia; dan di sisi Allah-lah tempat kembali yang baik (surga). (QS. Ali Imran [3]:14)

Pemenuhan akan harta tentu harus melakukan cara yang baik, serta pendayagunaan yang baik pula. Tanpa memperhatikan isyarat tersebut, manusia akan mengalami kesengsaraan dalam hidup. Daya tarik harta yang sangat menggiurkan dan menyilaukan mata bisa menyebabkan manusia lupa akan hakikat dirinya sebagai hamba Allah dan khalifah di muka bumi (Shihab: 405).

Oleh karena itu, agar tidak terperdaya kesenangan dunia karena berlimpahnya harta diperlukan keseimbangan dalam memenuhi kebutuhan dunia dan akhirat. Hal ini Allah menegaskan: 


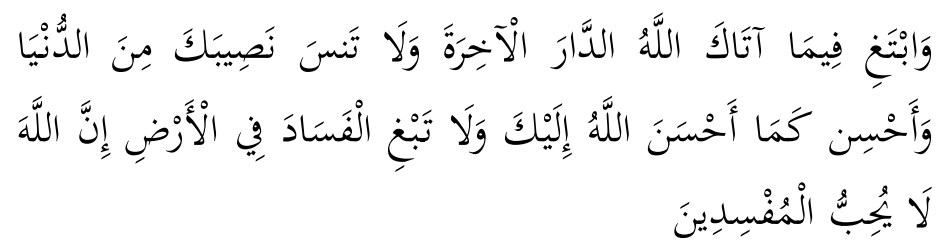

Artinya: "Dan carilah pada apa yang telah dianugerahkan Allah kepadamu (kebahagiaan) negeri akhirat, dan janganlah kamu melupakan bahagianmu dari (kenikmatan) duniawi dan berbuat baiklah (kepada orang lain) sebagaimana Allah telah berbuat baik kepadamu, dan janganlah kamu berbuat kerusakan di (muka) bumi. Sesungguhnya Allah tidak menyukai orangorang yang berbuat kerusakan. (QS. alQashash [28]: 77).

Berdasarkan ayat di atas, pendayagunaan harta dan jabatan didayagunakan di Jalan Allah, yakni dengan sebaik-baiknya, penuh tanggung jawab dan sesuai dengan tuntunan Allah SWT dan Rasul-Nya. Harta digunakan untuk kemaslahatan kehidupan duniawi, dan juga digunakan sebagai infak dan bershadaqah untuk kebutuhan akhirat. Hal ini ini juga ditegaslan dalam firman Allah berikut: 


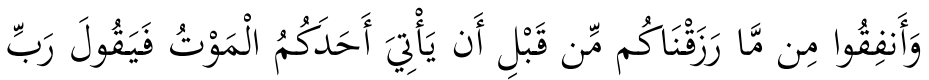

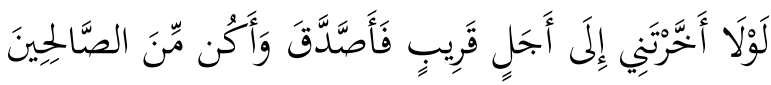

Artinya: "Dan belanjakanlah sebagian dari apa yang telah Kami berikan kepadamu sebelum datang kematian kepada salah seorang di antara kamu; lalu ia berkata: "Ya Tuhanku, mengapa Engkau tidak menangguhkan (kematian) ku sampai waktu yang dekat, yang menyebabkan aku dapat bersedekah dan aku termasuk orang-orang yang shaleh?" (QS. al-Munaafiquun [63]: 10).

Harta sebagai sarana investasi amal shaleh dengan menginfakkan kepada orang karena Allah. Hal ini sesuai dengan riwayat berikut:

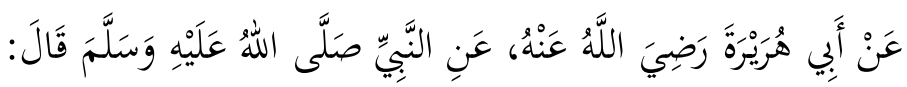

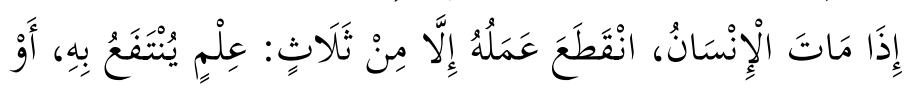

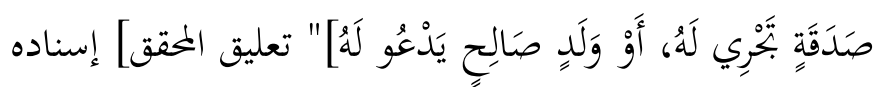

صحيح

Artinya: "Dari Abu Hurairahra berkata ,Nabi saw bersabda : Apabila manusia telah meninggal dunia maka terputuslah (pahala) amalnya kecuali dari 3 hal, yaitu: Ilmu yang dimanfaatkan, shadaqah yang mengalir untuknya atau anak soleh yang mendoakan 
untuk kebaikannya. HR Ad-Darimi dan tirmidzi. (Sunan Darimi 1/462 dan sunan tirmidzi 3/53..Sanadnya sohih.)

Sedangkan jabatan juga didayagunakan secara baik dan penuh amanah, sebab di hari akhirat kelak jabatan itu akan dipertanggung-jawabkan, sebagaimana firman Allah SWT:

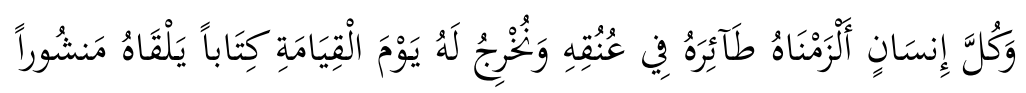

Artinya: "Dan tiap-tiap manusia itu telah Kami tetapkan amal perbuatannya (sebagaimana tetapnya kalung) pada lehernya. Dan Kami keluarkan baginya pada hari kiamat sebuah kitab yang dijumpainya terbuka.” (QS. al-Israa' [17]: 13).

Berdasarkan beberapa uraian di atas, dapat disimpulkan bahwa pendayagunaan harta untuk berinvestasi amal shaleh, seperti berinfak dan bershadaqah serta menggunakan jabatan untuk kemaslahatan umat sesuai syariat Islam. 


\section{Rangkuman}

1. Hakikat harta dan dan jabatan adalah merupakan amanah dan karunia Allah. Oleh karenanya, harta wajib dijaga dan dijalankan atau dipelihara serta dilaksanakan sesuai kehendak yang memberi amanah, yakni Allah SWT.

2. Kewajiban mencari harta dalam Islam didasarkan pada surah al-Jumu'ah ayat 10 dan al-Qashash ayat 77 dengan tujuan untuk memenuhi kebutuhan hidup duniawi juga diorientasikan untuk menunjang keperluan akhirat.

3. Sikap terhadap harta dan jabatan bagi seorang mukmin adalah menjaga diri dari harta yang dimiliki dan diyakini sebagai karunia yang diberikan Allah dan sebagai ujian bagi manusia untuk mengujinya apakah ia menjadi hamba yang bersyukur atau seorang hamba yang kufur kepada Allah serta menjalankan jabatan yang diterima sebagai amanah.

4. Pendayagunaan harta untuk berinvestasi amal shaleh, seperti berinfak dan bershadaqah serta menggunakan jabatan untuk kemaslahatan umat sesuai syariat Islam. 


\section{Latihan/Tugas/Eksperimen}

1. Diskusikan bentuk syukur dan kufur terhadap harta dan jabatan!

2. Cari ayat dan hadits tentang konsekuensi syukur dan kufur tersebut!

3. Berikan pandangan anda tentang hikmah rahasia infak dan shadaqah di jalan Allah terhadap kehidupan manusia!

\section{DAFTAR PUSTAKA}

al-Jazairi, Abu Bakr Jabir, Ensiklopedi Muslim: Minhajul Muslim, Jakarta Timur: Darul Falah: 2003.

Compact Disc (CD) Ensiklopedi Hadits 9 Imam.

Departemen Agama RI, Al-Qur'an dan Tafsirnya, Jakarta: Departemen Agama RI, 2010.

Departemen Pendidikan Nasional, Kamus Besar Bahasa Indonesia, Jakarta: Gramedia Pustaka Utama: 2008.

Djamil, Fathurrahman,1Filsafat Hukum Islam, Jakarta: Logos Wacana Ilmu, 1999.

Pasha, Musthafa Kamal, dkk., Fikih Islam Sesuai Dengan Keputusan Tarjih, Yogyakarta: Citra Karsa Mandiri, 2009. 
Rahardjo, M. Dawam, Islam dan Transformasi SosialEkonomi, Yogyakarta: Lembaga Studi Agama dan Filsafat, 1999.

Shihab, Quraish, Wawasan al-Qur'an, Bandung: Mizan, 2003.

Syafei, Rachmat, Fiqih Muamalah, Bandung: Pustaka Setia, 2001. 


\section{BIODATA PENULIS}

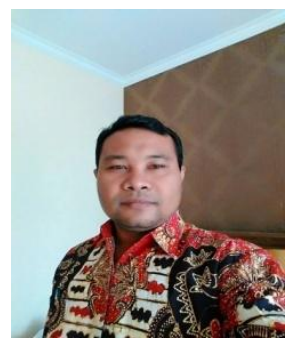

SUPRIYADI, M.PdI. Merupakan dosen tetap di PGSD-FKIP Universitas Muhammadiyah Sidoarjo. Lulus dari sarjana pendidikan Islam di Fakultas Agama Islam Universitas Muhammadiyah Malang, ia menamatkan program magister pendidikan Islam di

Universitas Muhammadiyah Sidoarjo pada tahun 2007 dengan tesis mengenai pergeseran orientasi pondok pesantren. Ia juga tercatat sebagai penulis buku pelajaran Al-Islam SMA Muhammadiyah, dan majalah Al-Muslimun.

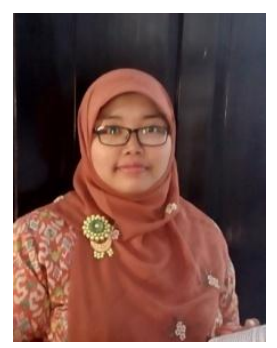

Anis Farihah, M.Th.I. Penulis adalah putri pertama Bpk. Sudarsono dan Ibu Nur Khaula, sempat mengenyam pendidikan tinggi di Sekolah Tinggi Agama Islam Negeri (STAIN) Ponorogo selama satu tahun. Karena harus kembali ke Sidoarjo, maka studi S1 diteruskan di IAIN Sunan Ampel Surabaya (sekarang UIN Sunan Ampel) Lulus Tahun 2008. Dilanjutkan Magister Theologi Islam didapatkan di Pasca Sarjana IAIN Sunan Ampel selesai Tahun 2013. Selain aktif di beberapa ortom Muhammadiyah, yakni Nasyiatul 'Aisyiyah dan 'Aisyiyah, penulis juga merupakan tenaga 
pendidik tetap mata kuliah Al-Islam dan Kemuhammadiyahan di Fakultas Teknik Universitas Muhammadiyah Sidoarjo. 